Prepared in cooperation with the City of Wichita, Kansas as part of the Equus Beds Groundwater Recharge Project

\title{
Effects of Experimental Passive Artificial Recharge of Treated Surface Water on Water Quality in the Equus Beds Aquifer, 2009-2010
}

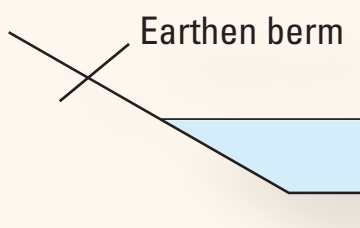

6-inch passive recharge well (RB1-P well) RB1-TR sampling location

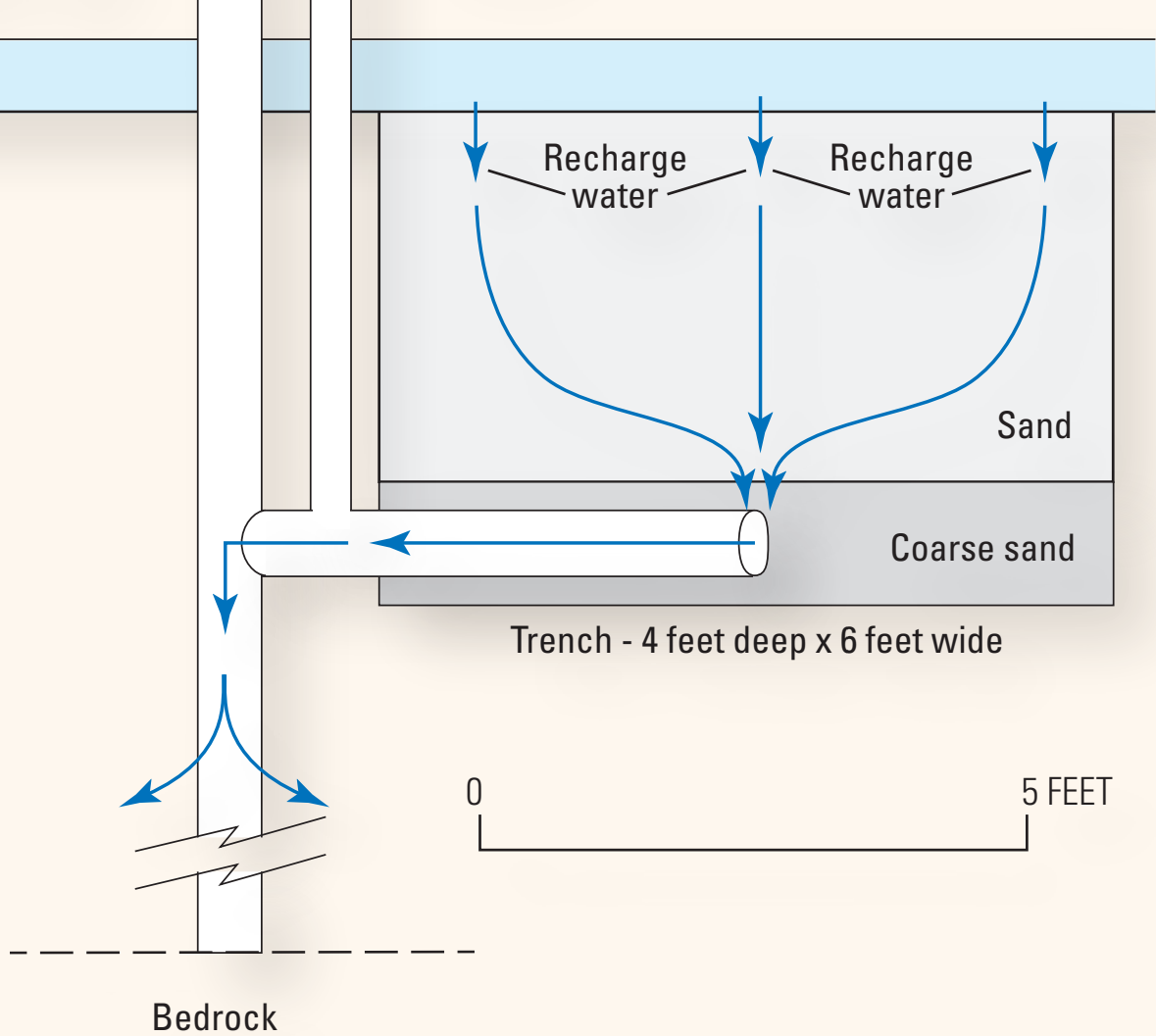

Scientific Investigations Report 2011-5070 
Cover illustration: Part A from figure 2 in this report. 


\section{Effects of Experimental Passive Artificial Recharge of Treated Surface Water on Water Quality in the Equus Beds Aquifer, 2009-2010}

By Linda Pickett Garinger, Aaron S. King, and Andrew C. Ziegler

Prepared in cooperation with the City of Wichita, Kansas as part of the Equus Beds Groundwater Recharge Project

Scientific Investigations Report 2011-5070 


\section{U.S. Department of the Interior \\ KEN SALAZAR, Secretary \\ U.S. Geological Survey \\ Marcia K. McNutt, Director}

\section{U.S. Geological Survey, Reston, Virginia: 2011}

For more information on the USGS - the Federal source for science about the Earth, its natural and living resources, natural hazards, and the environment, visit http://www.usgs.gov or call 1-888-ASK-USGS.

For an overview of USGS information products, including maps, imagery, and publications, visit http://www.usgs.gov/pubprod

To order this and other USGS information products, visit http://store.usgs.gov

Any use of trade, product, or firm names is for descriptive purposes only and does not imply endorsement by the U.S. Government.

Although this report is in the public domain, permission must be secured from the individual copyright owners to reproduce any copyrighted materials contained within this report.

Suggested citation:

Garinger, L.P., King, A.S., and Ziegler, A.C., 2011, Effects of experimental passive artificial recharge of treated surface water on water quality in the Equus Beds Aquifer, 2009-2010: U.S. Geological Survey Scientific Investigations Report 2011-5070, 106 p. 


\section{Acknowledgments}

The study presented in this report was conducted in cooperation with the City of Wichita as part of the Equus Beds groundwater recharge project. The authors thank City of Wichita personnel Rich Robinson and Megan Schmeltz for providing data and technical assistance throughout this experiment. We also thank Terryl Pajor, Vernon Strasser, and laboratory staff of the City of Wichita Municipal Water and Wastewater Laboratory for conducting laboratory analyses for this study. We are grateful to Deb Ary (City of Wichita) and Tim Boese (Kansas Groundwater Management District No. 2) for providing helpful reviews of this document.

The authors appreciate the outstanding efforts of United States Geological Survey Wichita Field Office personnel Trudy Bennett, Bea Ritchie, Carl Collins, and James Beilman for collecting water samples, measuring water levels, maintaining equipment, and conducting bacterial analyses. We thank Greg Stanton and Jonathan Thomas of the United States Geological Survey Texas Water Science Center for collecting and analyzing borehole geophysical data. We also thank Deneise Schneider for maintaining data records and field information, and Brian Klager for preparing figures and tables, and doing the $\mathrm{QAOC}$ analysis in this report. Technical reviews by Barbara Mahler and Dave Metge greatly improved the quality of this report. 



\section{Contents}

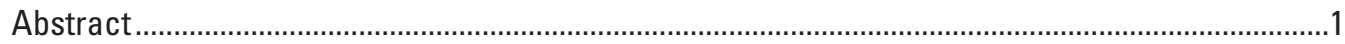

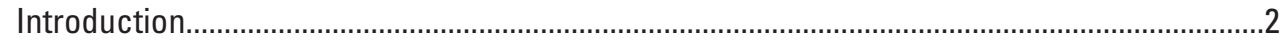

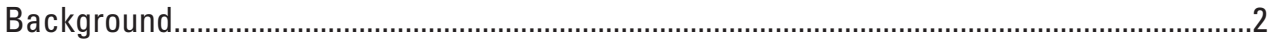

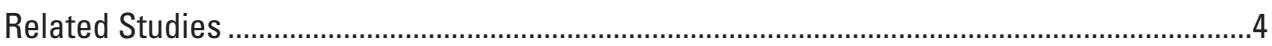

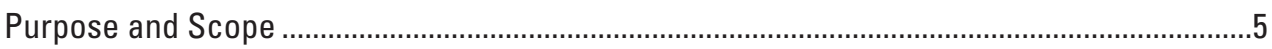

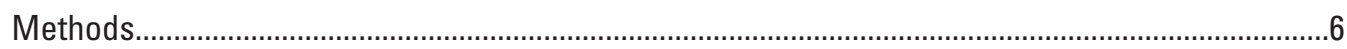

Experimental Test Site: Recharge Basin 1 ………………...........................................

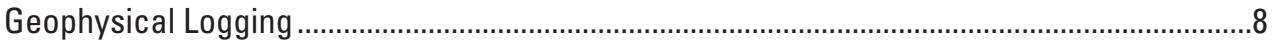

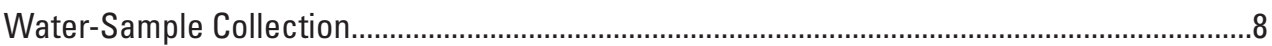

Discrete Water-Quality Samples..................................................................................

Continuous Water-Quality Monitoring...............................................................................11

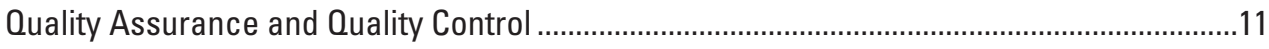

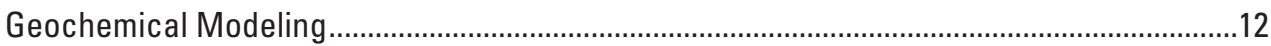

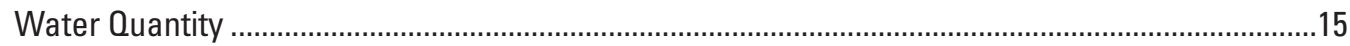

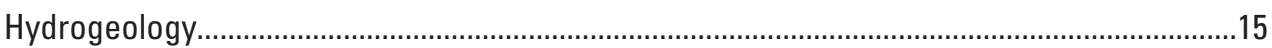

Water-Level Altitude from Continuous Monitors....................................................................16

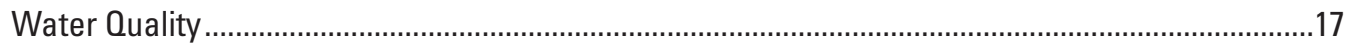

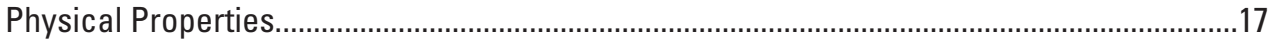

Water-Quality Monitor Data..............................................................................................

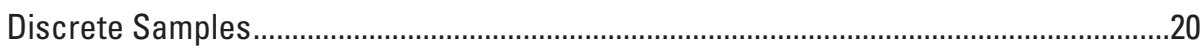

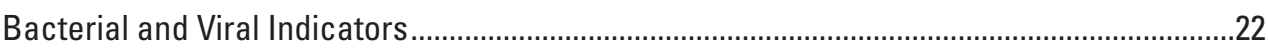

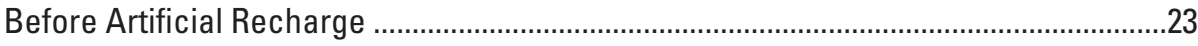

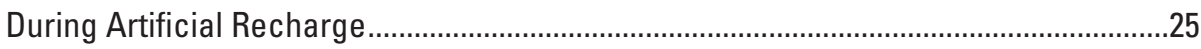

After Artificial Recharge and Before Water Withdrawal.................................................26

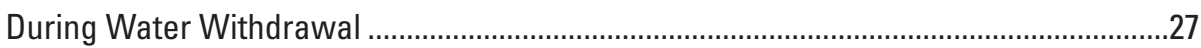

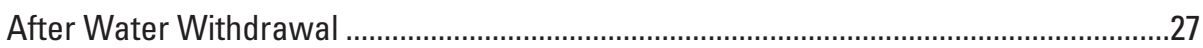

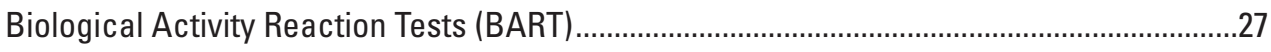

Select Major lons, Trace Elements, and Organic Compounds.................................................29

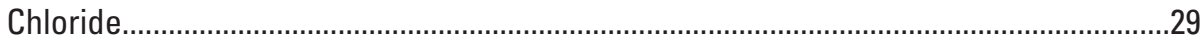

Arsenic

Iron

Atrazine

Geochemical Simulations.................................................................................................

Effects of Experimental Passive Artificial Recharge: Synthesis..................................................40

Before Artificial Recharge (January 1 Through April 2, 2009) ................................................40

During Artificial Recharge (April 3 Through April 30, 2009) ...................................................40

After Artificial Recharge and Before Water Withdrawal (May 1 Through July 6, 2009).........41

During Water Withdrawal (July 7 Through 21, 2009 And August 11 Through 14, 2009) ..........41

After Water Withdrawal (August 15, 2009 Through March 22, 2010) .....................................41

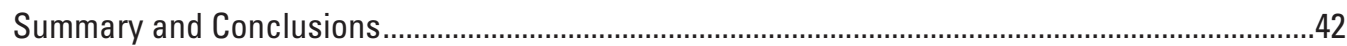

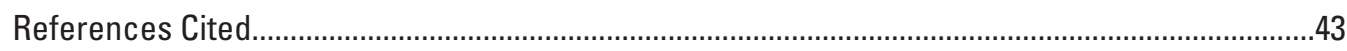

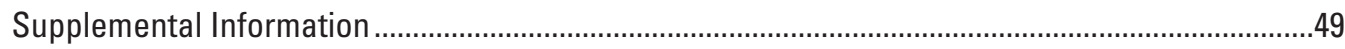




\section{Figures}

1. Map showing extent of Equus Beds aquifer, areas where chloride concentrations equal 250 milligrams per liter or more, and location of artificial recharge sites and study area near Wichita, south-central Kansas.

2. Aerial photograph showing location Test site details, including $(A)$ schematic of experimental passive recharge system $(B)$ schematic of RB1 basin and trench, and $(C)$ aerial photo of test site with monitoring well locations. Adapted from drawing D005B, City of Wichita.

3. Photograph showing RB1-TR, RB1-P well, and RB1-PMS wells installed along the eastern edge of the original RB1 basin. Photographed from the northeast during artificial recharge when trench was flooded with treated surface water.

4. Graphs showing borehole geophysical logs of $(A)$ natural gamma radiation in RB1-P well and RB1-PMS shallow and deep wells $(B)$ vertical flow in RB1-P well under ambient and pumped flow conditions $(C)$ temperature in RB1-P well and RB1-PMS shallow and deep wells $(D)$ dissolved oxygen in RB1-P well and RB1-PMS shallow and deeps wells, before artificial recharge

5. Graphs showing continuous measurement of: $(A)$ water-level altitude; $(B)$ turbidity; $(C)$ specific conductance; and $(D)$ dissolved oxygen at RB1 monitoring sites.

6. Graph showing oxidation-reduction potential from samples collected at RB1 sites during 2009-2010.

7. Graphs showing indicator bacteria densities from selected analytical methods in water samples collected from study area during 2009-2010; (A) Total coliform LES Endo method (membrane Endo agar, Lawrence Experiment Station) $(B)$ fecal coliform, M-FC MF (0.7-micron membrane filtration, Fecal Coliform agar) (C) Escherichia coli (modified thermotolerant Escherichia coli membrane filtration method).

8. Graphs showing indicator organism densities in water samples collected from study area during 2009-2010; (A) Coliphage, Esterichia coli, Famp host (single agar layer method) (B) Coliphage, Esterichia coli, C13 host (single agar layer method) (C) Clostridium perfringens (Clostridium perfringens agar membrane filtration method)

9. Graphs showing $(A)$ IRB BART, Percentage of samples with detections of enteric bacteria; $(B)$ IRB BART, Detections of potential well-fouling iron-related bacteria; $(C)$ SRB BART, Detections of sulfate-reducing bacteria.

10. Piper diagrams showing major ion chemistry of water samples from RB1 area wells $(A)$ before artificial recharge $(B)$ during artificial recharge $(C)$ after artificial recharge and before water withdrawal $(D)$ during water withdrawal $(E)$ after water withdrawal

11. Graph showing measured chloride concentrations in water samples collected from RB1 monitoring sites, January 2009 through March 2010.

12. Graph showing measured arsenic concentrations in water samples collected from RB1 monitoring sites, January 2009 through March 2010.

13. Graph showing measured iron concentrations in water samples collected from RB1 monitoring sites, January 2009 through March 2010.

14. Graph showing measured atrazine concentrations in water samples collected from RB1 monitoring sites, January 2009 through March 2010.

15. Graphs showing saturation indices with respect to: $(A)$ calcite $(B)$ iron hydroxide $(C)$ manganite $(D)$ scorodite calculated for groundwater samples collected from RB1 site, 2009-2010. 


\section{Tables}

1. Data-collection sites for RB1 passive recharge investigation, south-central Kansas, 2009-2010

2. Summary of replicate pairs analyzed as part of the Equus Beds Passive Recharge Project at RB1.

3. Summary of blank samples analyzed as part of the Equus Beds Passive Recharge Project at RB1.

4. Water-quality constituents analyzed in water samples collected from RB1 sites, 2009-2010

5. Summary of physical property data from water samples collected as part of the Equus Beds Experimental Passive Recharge Project at RB1, 2009-2010

6. Summary of bacterial and viral indicator data from water samples collected as part of the Equus Beds Experimental Passive Recharge Project at RB1, 2009-2010

7. Summary of iron related bacteria data and sulfate-reducing bacteria data from biotester analysis of water samples collected as part of the Equus Beds Passive Recharge Project at RB1, 2009-2010

8. Summary of major ion data from water samples collected as part of the Equus Beds Experimental Passive Recharge Project at RB1, 2009-2010

9. Summary of trace element and atrazine concentrations from water samples collected as part of the Equus Beds Experimental Passive Recharge Project at RB1, 2009-2010.

10. Saturation indices calculated for groundwater samples collected from RB1 sites, January 2009-March 2010 


\section{Conversion Factors}

\begin{tabular}{|c|c|c|}
\hline Multiply & By & To obtain \\
\hline \multicolumn{3}{|c|}{ Length } \\
\hline inch (in.) & 2.540 & centimeter $(\mathrm{cm})$ \\
\hline foot (ft) & 0.3048 & meter $(\mathrm{m})$ \\
\hline mile (mi) & 1.609 & kilometer $(\mathrm{km})$ \\
\hline \multicolumn{3}{|c|}{ Area } \\
\hline square foot $\left(\mathrm{ft}^{2}\right)$ & 0.09290 & square meter $\left(\mathrm{m}^{2}\right)$ \\
\hline \multicolumn{3}{|c|}{ Volume } \\
\hline gallon (gal) & 0.003785 & cubic meter $\left(\mathrm{m}^{3}\right)$ \\
\hline gallon (gal) & 3.875 & liter $(\mathrm{L})$ \\
\hline \multicolumn{3}{|c|}{ Flow rate } \\
\hline cubic foot per second $\left(\mathrm{ft}^{3} / \mathrm{s}\right)$ & 0.02832 & cubic meter per second $\left(\mathrm{m}^{3} / \mathrm{s}\right)$ \\
\hline $\begin{array}{l}\text { gallons per day per square foot } \\
\qquad(\mathrm{gal} / \mathrm{d}) / \mathrm{ft}^{2}\end{array}$ & 40.74 & $\begin{array}{l}\text { Liters per day per square meter } \\
(\mathrm{L} / \text { day }) / \mathrm{m}^{2}\end{array}$ \\
\hline foot per day (ft/d) & .3048 & meter per day $(\mathrm{m} / \mathrm{d})$ \\
\hline gallon per minute (gal/min) & 0.06309 & liter per second $(\mathrm{L} / \mathrm{s})$ \\
\hline \multicolumn{3}{|c|}{ Mass } \\
\hline ounce, avoirdupois (oz) & 28.35 & $\operatorname{gram}(\mathrm{g})$ \\
\hline pound, avoirdupois (lb) & 0.4536 & kilogram $(\mathrm{kg})$ \\
\hline \multicolumn{3}{|c|}{ Concentration } \\
\hline micrograms per liter $(\mu \mathrm{g} / \mathrm{L})$ & 1.0 & part per billion (ppb) \\
\hline milligrams per liter (mg/L) & 1.0 & part per million (ppm) \\
\hline
\end{tabular}

Temperature in degrees Celsius $\left({ }^{\circ} \mathrm{C}\right)$ may be converted to degrees Fahrenheit $\left({ }^{\circ} \mathrm{F}\right)$ as follows: ${ }^{\circ} \mathrm{F}=\left(1.8 \times{ }^{\circ} \mathrm{C}\right)+32$

Temperature in degrees Fahrenheit $\left({ }^{\circ} \mathrm{F}\right)$ may be converted to degrees Celsius $\left({ }^{\circ} \mathrm{C}\right)$ as follows: ${ }^{\circ} \mathrm{C}=\left({ }^{\circ} \mathrm{F}-32\right) / 1.8$

Vertical coordinate information is referenced to the North American Vertical Datum of 1988 (NAVD 88).

Horizontal coordinate information is referenced to the North American Datum of 1983 (NAD 83). Altitude, as used in this report, refers to distance above the vertical datum.

\section{Acronyms and Abbreviations Used in This Report}

$\begin{array}{ll}\text { ASR } & \text { aquifer storage and recovery } \\ \text { BART } & \text { biological activity reaction test } \\ \text { CBE } & \text { charge balance error } \\ \text { CFU } & \text { colony-forming unit } \\ \text { DO } & \text { dissolved oxygen } \\ \text { E. coli } & \text { Escherichia coli } \\ \text { ELISA } & \text { enzyme-linked immunosorbent assay }\end{array}$




\begin{tabular}{|c|c|}
\hline FID & floating intercedent device \\
\hline FNU & Formazin Nephelometric Unit \\
\hline GC/MS & gas chromatography/mass spectrometry \\
\hline GMD2 & Equus Beds Groundwater Management District 2 \\
\hline IRB & iron-related bacteria \\
\hline IW & index well \\
\hline $\mathrm{K}_{\mathrm{sp}}$ & solubility product \\
\hline LES Endo & membrane Endo agar, Lawrence Experimental Station \\
\hline $\mathrm{M}-\mathrm{FC}$ & membrane method fecal coliform \\
\hline MCL & maximum contaminant level \\
\hline MCLG & maximum contaminant level goal \\
\hline MF & membrane filter \\
\hline MN & upgradient well \\
\hline MPN & most probable number \\
\hline MPV & most probable value \\
\hline MS & downgradient well \\
\hline m-TEC & membrane-thermotolerant Escherichia coli \\
\hline NTRU & nephelometric turbidity ratio units \\
\hline NTU & nephelometric turbidity units \\
\hline ORP & oxidation-reduction potential \\
\hline PAC & powdered activated carbon \\
\hline pe & oxidation-reduction potential \\
\hline PFU & plaque-forming units \\
\hline PHREEQC & $\begin{array}{l}\text { USGS computer program used for low-temperature aqueous geochemistry } \\
\text { calculations }\end{array}$ \\
\hline QA/QC & quality assurance/quality control \\
\hline RB1 & recharge basin 1 \\
\hline RB2 & recharge basin 2 \\
\hline SC & specific conductance \\
\hline SDWR & secondary drinking water regulation \\
\hline SI & saturation index \\
\hline SRB & sulfate-reducing bacteria \\
\hline SSC & suspended sediment concentration \\
\hline USEPA & U.S. Environmental Protection Agency \\
\hline USGS & U.S. Geological Survey \\
\hline VBNC & viable but not culturable \\
\hline WWWL & Wichita Municipal Water and Wastewater Laboratory \\
\hline
\end{tabular}





\title{
Effects of Experimental Passive Artificial Recharge of Treated Surface Water on Water Quality in the Equus Beds Aquifer, 2009-2010
}

\author{
By Linda Pickett Garinger, Aaron S. King, and Andrew C. Ziegler
}

\section{Abstract}

Declining water levels and concerns about the migration of a known saltwater plume upgradient from public supply wells prompted the City of Wichita to investigate the feasibility of using artificial recharge to replenish the water supply in the Equus Beds aquifer. After preliminary testing, the City of Wichita began Phase I of the Equus Beds Aquifer Storage and Recovery Project in 2006. In 2009, the City of Wichita installed an experimental passive gravity recharge well and trench system to increase artificial recharge at Recharge

Basin 1, one of the six Phase I recharge sites.

The U.S. Geological Survey collected water samples from 13 sites and maintained 8 continuous monitors to test the recharge capacity of the experimental passive recharge system, the effect of the recharge on geochemistry of the aquifer, and the fate of bacteria and viruses present in the recharge water. About 576,000 gallons of treated surface water from the Little Arkansas River were recharged through the passive recharge well and trench system into the Equus Beds aquifer during April 2009. In May 2009, U.S. Geological Survey tests detected that bacterial and viral indicators (total coliform, fecal coliform, Escherichia coli, coliphage virus, and Clostridium perfringens) were entering the Recharge Basin 1 wells through the recharge system and recharge was discontinued. The City of Wichita disconnected the trench collection system from the passive gravity recharge well in July 2009, and in July and August 2009 withdrew 1,825,000 gallons of water from the aquifer at Recharge Basin 1 to remove the recharged water and avoid contamination of the aquifer.

The original recharge rate in Recharge Basin 1 was about 10.8 gallons per day per square foot. After installation of the passive recharge system, recharge water entered the aquifer through the passive well at a rate of about 19.2 gallons per day per square foot, a per unit area increase of about 78 percent.

During artificial recharge, continuous monitors recorded rising water-level altitudes in the passive gravity recharge well and nearby monitoring wells as water flowed at about 10 feet per day from the passive recharge well toward nearby downgradient monitoring wells. The increase in water level in this area would have the effect of temporarily slowing the eastward migration of saltwater from the nearby Burrton plume.

Bacterial and viral indicators were detected in water samples from Recharge Basin 1 sites before and immediately after the installation of the passive gravity recharge well and trench system, during artificial recharge, and after artificial recharge. After water withdrawal in August 2009 and through the end of data collection in March 2010, detections of bacterial and viral indicators in groundwater decreased to densities similar to those before installation of the passive recharge system.

Concentrations of chloride in samples collected from the trench, passive gravity recharge well, and nearby monitoring wells increased from an average of 34 milligrams per liter before artificial recharge to an average of 64 milligrams per liter during artificial recharge, reflecting the addition of recharge water with measured chloride concentrations of 62 to 94 milligrams per liter. When water was being pumped out of the aquifer through the passive gravity recharge well, chloride concentrations increased to 94 milligrams per liter in the removed water and increased to 150 milligrams per liter in the deep monitoring well nearest the passive gravity recharge well, indicating that, as water was being pumped from the passive well, water with a large chloride concentration from elsewhere in the aquifer was flowing toward the passive well. Chloride concentrations did not exceed the U.S. Environmental Protection Agency Secondary Drinking Water Regulation of 250 milligrams per liter in any Recharge Basin 1 samples collected as part of the study.

Iron concentrations exceeded the U.S. Environmental Protection Agency Secondary Drinking Water Regulation of 300 micrograms per liter in three wells before, during, and after recharge, and were not substantially affected by the addition of oxygenated treated surface water into the system. Arsenic concentrations exceeded the U.S. Environmental Protection Agency Maximum Contaminant Level of 10 micrograms per liter in some deep wells, but did not exceed the Maximum Contaminant Level in shallow wells. The addition 
of oxygenated treated surface water to the aquifer did not substantially change arsenic concentrations at Recharge Basin 1 monitoring sites.

Atrazine concentrations in samples collected from Recharge Basin 1 well sites during 2009-2010 did not exceed the Maximum Contaminant Level of 3 micrograms per liter and were largest in groundwater samples collected 4 to 6 days after artificial recharge was discontinued. Atrazine concentrations in samples collected after the passive gravity recharge well experiment were similar to those collected before the experiment began.

Saturation indices for calcite $\left(\mathrm{CaCO}_{3}\right)$, iron hydroxide $\left(\mathrm{Fe}_{3}(\mathrm{OH})_{8}\right)$, and manganite $(\mathrm{MnOOH})$ increased during artificial recharge while saturation indices for scorodite $\left(\mathrm{FeAsO}_{4}: 2 \mathrm{H}_{2} \mathrm{O}\right)$ decreased, indicating that mixing oxygenated artificial recharge water with aquifer water caused conditions favorable for oversaturation and precipitation of some minerals. Saturation indices indicated the potential for calcite and iron hydroxide precipitation in some samples during the study period.

\section{Introduction}

\section{Background}

The Equus Beds aquifer, named for the Pleistocene horse fossils in the aquifer sediments, is the easternmost extension of the larger High Plains aquifer system (fig. 1). The Equus Beds aquifer consists of alluvial deposits of sand and gravel interbedded with clay or silt (Williams and Lohman, 1949). The general direction of groundwater movement within the study area is to the east (Aucott and others, 1998) except where the hydraulic gradient is altered by pumping wells and near a lowhead dam on the Little Arkansas River at Halstead (fig. 1).

The Equus Beds aquifer is a primary water supply source for Wichita, Kansas, and the surrounding area because of shallow depth to water, large saturated thickness (Hansen and Aucott, 2004), and generally good water quality (Ziegler and others, 1999). The water table in the aquifer may be as little as 10 feet (ft) below land surface and saturated thickness as much as $250 \mathrm{ft}$ (Myers and others, 1996). In 2008, about 40 percent of the water supply needs for the City of Wichita came from the Equus Beds aquifer (D. Ary, City of Wichita, oral commun., 2010).

The primary surface-water drainage for the Equus Beds aquifer is the Little Arkansas River (fig. 1). Land use in the Little Arkansas River Basin is primarily agricultural and includes the production of livestock (pasture and range) and field crops. Field crops include corn, grain sorghum, soybeans, and wheat (Kansas Department of Agriculture, 2009). Agricultural chemicals applied to enhance crop production in the basin include fertilizers (such as nitrate, ammonia, and phosphorus), pesticides, herbicides, and fungicides (U.S. Department of Agriculture website, http://quickstats.nass.usda. gov/results/2A9CA557-2896-3E90-BF69-DC85C1D98E49).

The well field developed by the City of Wichita in the Equus Beds aquifer during the 1940s and 1950s is one of the primary sources of water for the city and the surrounding area (fig. 1). As of 2005, there were 55 active city publicsupply wells in the Wichita Equus Beds well field. Numerous irrigation wells also withdraw water from the aquifer within the boundaries of Groundwater Management District No. 2 (GMD2) (Equus Beds Groundwater Management District No. 2, 1990) (fig. 1). Water use for irrigation and public supply has caused water levels to decline as much as $40 \mathrm{ft}$ in some areas (Aucott and others, 1998). Declining water levels likely represent a diminished water supply. These, in turn, may accelerate migration of saltwater from the Burrton oil-field to the northwest and the Arkansas River to the southwest into the freshwater of the Equus Beds aquifer (fig. 1) (Hansen, 2007).

The City of Wichita began using water from Cheney Reservoir (fig. 1) in 1965 to supplement its supply from the Equus Beds aquifer. The proportion of the water supply obtained from Cheney Reservoir increased from 20 percent in 1965 to 44 percent in 1994. From 1995 through 2010, water from Cheney Reservoir ranged from 51 to 69 percent of Wichita's water supply (Ziegler and others, 2010). The increased reliance on surface water from Cheney Reservoir was part of Wichita's Integrated Local Water Supply Plan implemented in 1993 (Warren and others, 1995). This plan was initiated to ensure that the city's water-supply needs are met through 2050 by promoting conservation, increasing water use from Cheney Reservoir, and decreasing pumping from city wells in the Wichita Equus Beds well field. The plan also calls for investigating Equus Beds recharge using excess water from the Little Arkansas River. As the population in the Wichita area increases, demands for water could exceed existing supplies as early as 2050 if no additional water supply is acquired (Warren and others, 1995; J. Blain, oral commun., 2005).

In 1956, Stramel $(1956,1962 a, b, 1967)$ proposed the artificial recharge of the Equus Beds groundwater reservoir by recharging the aquifer with runoff during periods of abundant precipitation. This artificially recharged water then could be recovered by pumping from the aquifer during periods of drought. Stramel proposed using a variety of techniques including water spreading, recharge pits or ponds, recharge wells, and induced recharge by pumping. He also suggested investigation of the relation between streamflow or stage and water quality for the Arkansas River, Little Arkansas River, and Kisiwa Creek as sources for artificial recharge. Of these streams, the Little Arkansas River had the best known water quality.

The Equus Beds Groundwater Recharge Demonstration Project began in 1995. The purpose of the demonstration project was to investigate the feasibility of artificial recharge and its effects on the water quantity and quality of the Equus Beds aquifer. A demonstration project conducted from 1995 to 2002 


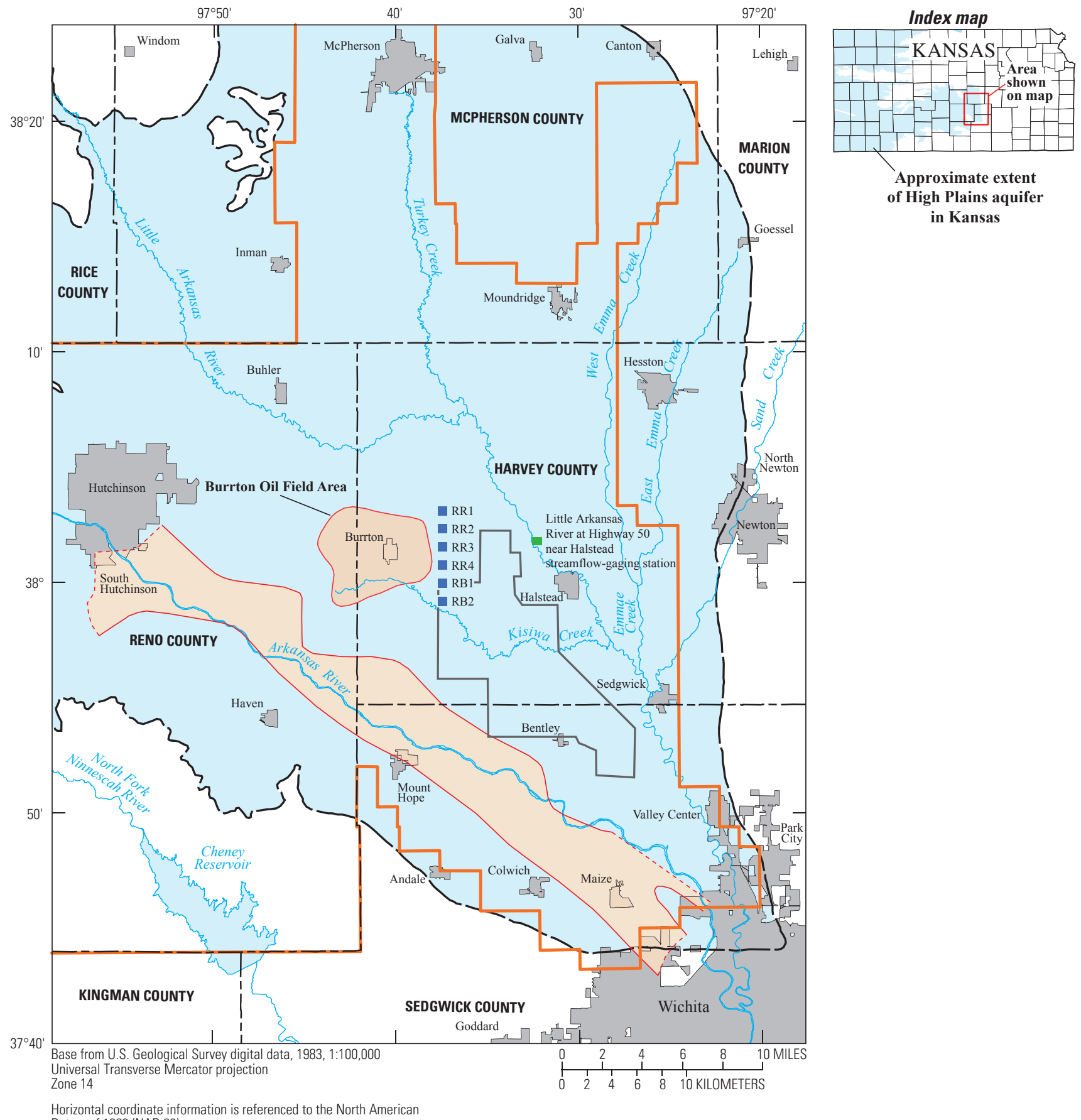

EXPLANATION

Area where chloride concentration equals 250 milligrams per liter or more

Equus Beds aquifer

- - - Approximate boundary of Equus Beds aquifer (Juracek and Hansen, 1995)

Boundary of chloride concentration equal to or greater than $\mathbf{2 5 0}$ milligrams per liter-Dashed where extent is unknown

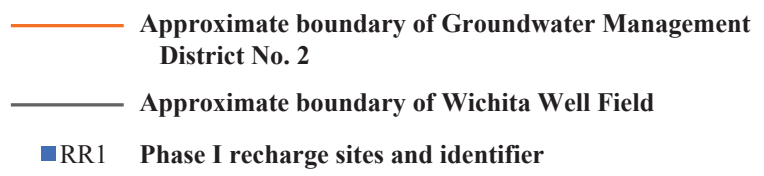

Approximate boundary of Groundwater Management District No.

RR1 Phase I recharge sites and identifier

Figure 1. Extent of Equus Beds aquifer, areas where chloride concentrations equal 250 milligrams per liter or more, and location of artificial recharge sites and study area near Wichita, south-central Kansas. Modified from Ziegler and others, 2010. 
Effects of Artificial Recharge of Treated Surface Water on Water Quality in the Equus Beds Aquifer, 2009-2010

determined that the sources of recharge water were chemically compatible with the receiving groundwater, and in 2007 full-scale recharge began. The role of the U.S. Geological Survey (USGS) in the study was to document hydrologic and water-quality changes and conditions within the study area, to identify probable causes, and to develop baseline conditions for evaluating the effects of larger full-scale artificial recharge. Ziegler and others (1999) reported that the sources of recharge water were chemically compatible with the receiving groundwater and that constituents of concern were sodium, chloride, nitrate, iron, manganese, atrazine, and total coliform bacteria. Ziegler and others (2001) reported that groundwater quality in the Equus Beds aquifer was not substantially changed by 3 years of recharge during the demonstration project. Schmidt and others (2007) determined that chemical precipitation of calcite and iron hydroxide are likely to occur, and that the potential for biofouling by iron-related bacteria exists when fully oxygenated treated stream water is injected into the aquifer.

Artificial recharge is being conducted by the City of Wichita through its Equus Beds Aquifer Storage and Recovery (ASR) Project Phase I to store and later recover groundwater and to form a hydraulic barrier to a known chloride-brine plume near Burrton, Kansas (fig. 1). Phase I of the Equus Beds ASR Project consists of providing as much as 10 million gallons per day recharge to the aquifer through four recharge wells and two recharge basins. The Equus Beds Aquifer Storage and Recovery Project Phase I pumps water from the Little Arkansas River or from streambank filtration wells when flow in the river exceeds base flow. Base flow is defined as 57 cubic feet per second $\left(\mathrm{ft}^{3} / \mathrm{s}\right)$ from April 1 through September 30, and $20 \mathrm{ft}^{3} / \mathrm{s}$ from October 1 through March 31 as recorded at the USGS streamflow-gaging station on Little Arkansas River at Highway 50 near Halstead, Kansas (KS Permit No. KS-05-079-001, fig. 1). Surface water is processed through a treatment facility to remove suspended material and organic chemicals (powdered activated carbon treatment). This processed water is then recharged into the Equus Beds aquifer through two recharge basins, Recharge Basin 1 (RB1) and Recharge Basin 2 (RB2). Additionally, water from streambank filtration wells is artificially recharged through any of four injection wells (RR1-RR4) or through the recharge basins. The USGS has been monitoring the water-quality effects of artificial recharge on the Equus Beds as part of the Phase I project.

Primary constituents of concern for artificial recharge are sodium, chloride, nitrate (measured as nitrite plus nitrate), iron, manganese, atrazine, and total coliform bacteria (Ziegler and others, 1999). Chloride and atrazine are of particular concern because concentrations of these constituents in the Little Arkansas River frequently exceeded the Secondary Drinking Water Regulation (SDWR) of 250 milligrams per liter $(\mathrm{mg} / \mathrm{L})$ for chloride and the Maximum Contaminant Level (MCL) value of 3 micrograms per liter $(\mu \mathrm{g} / \mathrm{L})$ for atrazine established by the U.S. Environmental Protection Agency (USEPA) (Ziegler and others, 1999). Arsenic was added to the constituents of concern list (Ziegler and others, 2001) after the USEPA lowered the arsenic MCL from 50 to $10 \mu \mathrm{g} / \mathrm{L}$ effective January 2006 (U.S. Environmental Protection Agency, 2001b). Of additional interest is the fate of viruses and bacteria during artificial recharge with treated surface water.

Information to address concerns related to the effectiveness of a passive recharge system at removing atrazine and microbes from treated surface water before it enters the aquifer, potential for changes in the microbial population in the aquifer resulting from the introduction of oxygenated surface water, and the potential effectiveness of using artificial recharge to stop or slow the migration of a chloride plume is needed. To address these needs the USGS, in cooperation with the City of Wichita, conducted a supplemental investigation as part of the Equus Beds groundwater recharge project designed to evaluated flow of recharge water through an experimental passive gravity recharge well system. The supplemental investigation is referred to as the RB1 project.

\section{Related Studies}

Ziegler and others (1999) described the baseline water quality (1995-98) and preliminary effects of artificial recharge on the water quality of the Equus Beds aquifer. The report indicated that the initial effects of artificial recharge were minimal, that the recharge and aquifer water types were compatible, and that sodium, chloride, nitrate, iron, manganese, atrazine, and total coliform bacteria were constituents of concern. Concentrations of chloride and atrazine in water from some wells increased slightly after the artificial recharge project began approximating the recharge water concentrations; however, these concentrations were within the variance of baseline concentrations in the aquifer and considerably less than the USEPA SDWR and MCL. Ziegler and others (2001) reported that the overall effects of 3 years of recharge did not substantially change groundwater quality.

Schmidt and others (2007) presented the results from a simple mixing model using chloride as a tracer that indicated that the water in shallow (less than $80 \mathrm{ft}$ ) monitoring wells adjacent to the Little Arkansas River was 80 percent stream water. The mixing model also indicated that about 25 percent of the pumping well water at Halstead was from the shallow part of the aquifer.

Christensen and others $(2000,2003)$ developed sitespecific regression models to relate constituent concentrations from laboratory-analyzed samples to continuous in-stream sensor measurements of turbidity, specific conductance (SC), $\mathrm{pH}$, water temperature, and dissolved oxygen (DO) by plotting each explanatory variable against the response variable for the Little Arkansas River. Regression models were developed based on physical properties and water-quality analyses of water samples collected from 1995 through 2002. These models were used to compute alkalinity, dissolved solids, total suspended solids, sulfate, chloride, arsenic, and atrazine 
concentrations, and fecal coliform bacteria densities (Christensen and others, 2000, 2003).

Water quality in the Little Arkansas River and the Equus Beds aquifer from 1995 through 2005 before implementation of Phase I recharge was described by Ziegler and others (2010). Baseline sulfate and chloride concentrations frequently (in more than 5 percent of samples) exceeded the SDWR for these constituents. The trace elements arsenic, iron, and manganese frequently exceeded drinking water criteria. Atrazine, at concentrations much less than the MCL ( $<$ (less than) $0.05-0.09 \mu \mathrm{g} / \mathrm{L}$ ), was detected in 55 percent of samples collected from shallow index wells, indicating infiltration of the chemical from nearby applications. Total coliform was detected in at least one sample from most wells, but other indicator organisms (Clostridium perfringens and Escherichia coli (E. coli) coliphage) were not detected. Total and fecal coliform bacteria were detected in treated stream water and water from diversion wells.

Because coliform bacteria was detected in water used to artificially recharge the Equus Beds aquifer before Phase I recharge, studies investigating the fate of bacteria that may enter the aquifer during artificial recharge are of interest. Anders and others (2004) measured bacteria concentrations in water samples collected from the unsaturated zone at an artificial recharge site in Los Angeles County, California immediately before, 48 hours after, and more than one month after recharge with treated municipal wastewater. Bacteria were not detected immediately before artificial recharge began (April 4, 1994), but increased to concentrations of 8 to $>$ (greater than) $300 \mathrm{CFU} / 100 \mathrm{~mL}$ (colony- forming units per 100 milliliters) (total coliform) and 0 to $18 \mathrm{CFU} / 100 \mathrm{~mL}$ (fecal coliform) within 48 hours (April 6, 1994) after artificial recharge commenced. Concentrations returned to nondetectable levels about 2 months later (June 1, 1994). Anders and others (2003) found that bacteria moved with the recycled water about 3 meters within a few days. Subsequent controlled experiments using introduced bacteriophage as surrogates for human enteric viruses (viruses found in the intestines) and bromide as a tracer element indicated that the dominant mechanism for virus removal was adsorption not inactivation, although viruses can become inactivated following interaction with solid surfaces, particularly those of metal oxides. The quantity of virus removed increased with time, likely because of changes to the aquifer at the recharge site caused by the presence of entrapped air, sealing of the soil surface, and the presence of biofilms sealing the pores of the aquifer material (Anders and others, 2004).

In another study involving an artificial recharge system, Blanford and others (2005) evaluated the fate of a bacteriophage in a sandy aquifer at the U.S. Geological Survey Cape Cod Toxic-Substances Hydrology Research Site in Falmouth, Massachusetts. A bromide tracer and bacteriophage were injected into groundwater at the site. Water was collected from a set of downgradient multilevel monitoring wells and analyzed for bromide and bacteriophage concentrations. Results indicated that a small fraction of the injected bacteriophage remained viable throughout the experiment (about 70 days) and traveled 13 meters $(\mathrm{m})$ from the injection point. The conclusion is that if the bacteriophage behaves similarly to human infective virus, a potential health threat would exist downgradient from the point where the virus enters the groundwater.

The amount of time that bacteria and viruses will survive in a groundwater environment depends on many factors, including temperature, $\mathrm{pH}$, light, type of aquifer material, substances toxic to the bacteria or virus, dissolved oxygen, type of bacteria or virus, nutrients available, and predators in the environment. In general, the low temperature, dark, low predator environment of an aquifer is conducive to the survival of bacteria and viruses (Keswich and others, 1982; John and Rose, 2005; Foppen and Schijven, 2006; Cook and Bolster, 2007; Charles and others, 2009). Bacteria and viruses have been documented to survive in groundwater for extended periods of time. Estimates of times to inactivation range to as much as 250 days for bacteria at $10^{\circ} \mathrm{C}$, and 460 days for viruses at $4{ }^{\circ} \mathrm{C}$ (Keswich and others, 1982; Nevecherya and others, 2005). Dillon and others (2005) summarized data from 10 sites and reported that pathogenic viruses, bacteria, and protozoa became inactivated fastest under aerobic conditions. For example, they report that the time necessary to attenuate 90 percent (one log unit) of viruses is 1 to 10 days in an aerobic aquifer and 8 to 143 in an anaerobic aquifer.

Additionally, research indicates that pathogenic bacteria are capable of entering a viable but not culturable (VBNC) state when stressed (Roszak and Colwell, 1987; Byrd and others, 1991; Barcina and others, 1997). In this state, the bacteria will not grow in a laboratory culture, but may still be viable if it enters a host organism. Some laboratory tests may be better detectors of bacteria that have entered the VBNC state.

\section{Purpose and Scope}

This report describes the results of a supplemental investigation conducted in addition to the ongoing USGS monitoring activities. The smaller scale project was an experiment at RB1 designed to evaluate the flow of recharge water through an experimental passive gravity recharge well system and into the Equus Beds aquifer.

The purpose of this report is to describe the effects of experimental artificial recharge through a passive gravity recharge well on water-quantity and quality of the Equus Beds aquifer. Water diverted from the Little Arkansas River was passed through a treatment plant and then pumped into the passive gravity recharge well system at RB1 where it entered the Equus Beds aquifer. Continuous monitors measured water levels and water quality physical properties (such as SC and water temperature) once per hour throughout the passive gravity recharge well experiment. Water quality was assessed by laboratory analysis of water samples collected of diverted surface water from the Little Arkansas River, treated water used for recharge (RB1 source water), and water samples from 
11 monitoring sites located at the RB1 passive recharge site. Water samples collected before, during, and after the recharge process were analyzed for bacterial and viral indicators, major ions, trace elements, atrazine, and nutrients. Of primary concern was the effectiveness of the passive recharge system at removing atrazine and microbes from the surface water before it entered the aquifer. Another concern was the potential for changes in the microbial population in the aquifer resulting from the introduction of oxygenated surface water. Biological Activity Reaction Tests (BART) for iron-related bacteria and sulfate-reducing bacteria were conducted and were used in conjunction with geochemical speciation data and simulations to evaluate potential plugging of aquifer material resulting from precipitation of minerals. The effectiveness of using artificial recharge to effectively stop or slow the migration of a known chloride-brine plume immediately to the west of the recharge area was a third primary concern addressed in this report. The analysis of data collected by continuous monitors was evaluated to determine the local hydrogeologic effects of passive recharge on the Equus Beds aquifer at the RB1 site, specifically related to the chloride-brine plume.

\section{Methods}

\section{Experimental Test Site: Recharge Basin 1}

$\mathrm{RB} 1$ is the site for the investigation discussed in this report (fig. 2). RB1 was originally designed as an infiltration basin for the recharge of treated surface water. However, the clay content in the bottom material of the basin was greater than expected and the infiltration rate of recharge water was much less than the design rate of about 37.4 gallons per day per square foot (gal/d)/ $/ \mathrm{ft}^{2}$. In 2007, ring permeameter testing conducted at RB1 indicated average recharge rates of $16.5(\mathrm{gal} / \mathrm{d}) / \mathrm{ft}^{2}$ through the basin floor (P. Higgins, Burns \& McDonnell, written commun., 2010). However, observation of recharge at RB1 during artificial recharge in 2007 and 2008 indicated the true recharge capacity to be "substantially less" than 16.5 (gal/d)/ $\mathrm{ft}^{2}$ (P. Higgins, Burns \& McDonnell, written commun., 2010). The pump supplying water to the basin during artificial recharge had an approximate capacity of 1,000 gallons per minute ( $\mathrm{gal} / \mathrm{min}$ ) and could not be operated continuously because the infiltration rate was not sufficiently large (R. Robinson, oral commun., 2010). An upper estimate of the recharge capacity of the original RB1 basin is $1,400,000 \mathrm{gal} / \mathrm{d}$ or $10.8(\mathrm{gal} / \mathrm{d}) / \mathrm{ft}^{2}$ averaged in the basin area of about 134,000 square feet $\left(\mathrm{ft}^{2}\right)$.

RB1 was reconstructed to include an experimental 6-inch diameter passive gravity recharge well and trench system to facilitate the transport of recharge water into the aquifer. The original configuration of the basin with the approximate location of monitoring wells and a diagram of the trench and passive gravity recharge well configuration is shown in figure 2. The linear trench was installed along the eastern side of the original basin, and the passive gravity recharge well was installed near the center of the trench. Recharge water flowed through the sand-filled filtration trench, into a collection pipe, and then into the passive gravity recharge well (figs. 2 and 3).

Fourteen sites were used for water-quality sampling or monitoring, or both. (table 1 and fig. 2). The USGS streamflow-gaging station on the Little Arkansas River at Highway 50 near Halstead, Kansas (site 07143672) continuously recorded physical measurements including precipitation and SC. Diverted surface-water samples were collected at the PAC Building, Burrton, Kansas (Diverted SW, table 1). The treated water used for recharge (RB1 source water) was collected from an access faucet at RB1. Water from the recharge trench (RB1-TR) was collected through an access pipe in the system (fig. 2). The passive gravity recharge well (RB1-P well) was sampled and monitored in two depths within the well, RB1-P well shallow (50 ft depth) and RB1-P well deep (169.5 ft depth). (Although the RB1-P well is a single well, for the purposes of this report each monitoring depth may be referred to individually, as if it were a single well. The description "RB1-P well shallow and deep monitoring depths" or "RB1-P well shallow and deep sampling depths" may be used when referring to the RB1-P well monitoring and sampling locations. During water withdrawal in July and August, the designation of "RB1-P deep well" refers to samples collected of water withdrawn from the aquifer.) Two 4-inch monitoring wells, RB1-PMS shallow (about $84 \mathrm{ft}$ deep) and RB1-PMS deep (about $247 \mathrm{ft}$ deep), were installed about $30 \mathrm{ft}$ northeast of the RB1-P well. Three pairs of 2-inch diameter monitoring wells were already in place at RB1; an upgradient (MN shallow and deep) and two downgradient pairs (MS shallow and deep and IW-09 shallow and deep). Altitudes, screened intervals, depths, and USGS site identification numbers for the 14 sites sampled in this evaluation are shown in table 1 .

Figures 2 and 3 show the locations of the RB1-P well and monitoring wells located at RB1.

A total of 576,000 gallons (gal) of treated surface water were used to test the passive well and trench system at RB1: about 244,000 gal were pumped into the trench April 3-5, 2009; 292,000 gal April 13-17, 2009; and 40,000 gal on April 30, 2009 (R. Robinson, written commun., 2009).

The RB1 site was not recharged with treated surface water after April 30, 2009. The trench and passive well system received recharge by rainfall only after April 30, 2009.

The trench collection system was disconnected from the passive well on July 8, 2009. Approximately 1,500,000 gal of water were pumped out of the aquifer at the RB1 site through the RB1-P well July 7-21, 2009, and 325,000 gal August 11-14, 2009. 
$\boldsymbol{A}$

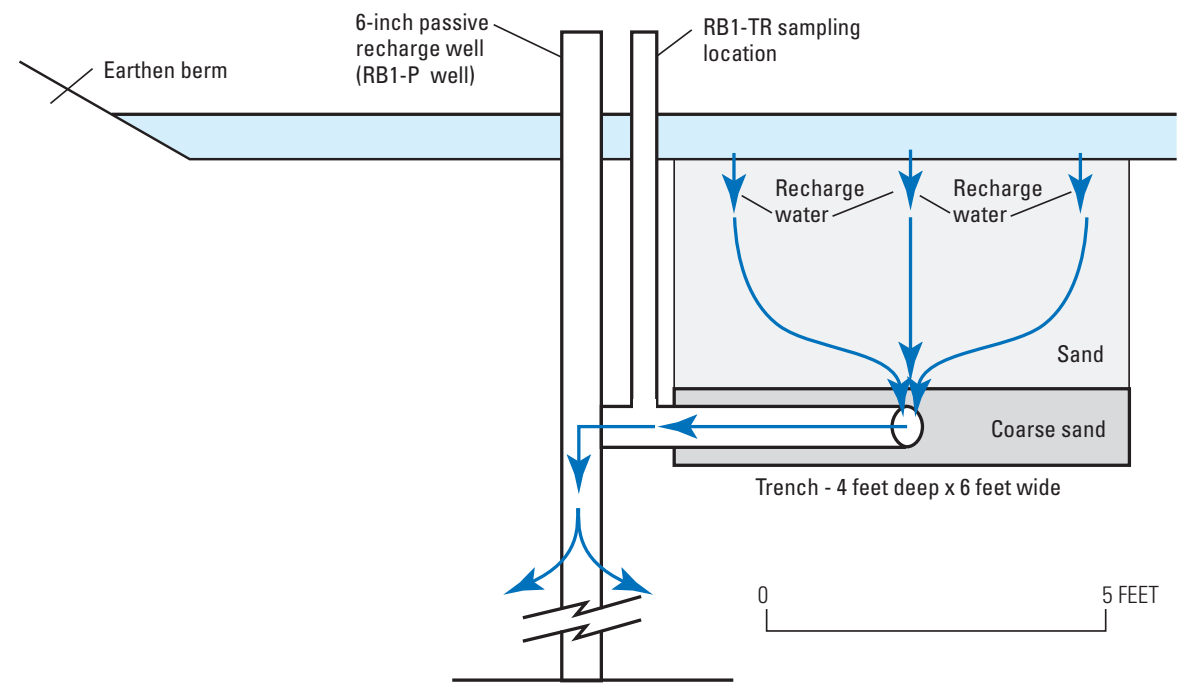

C

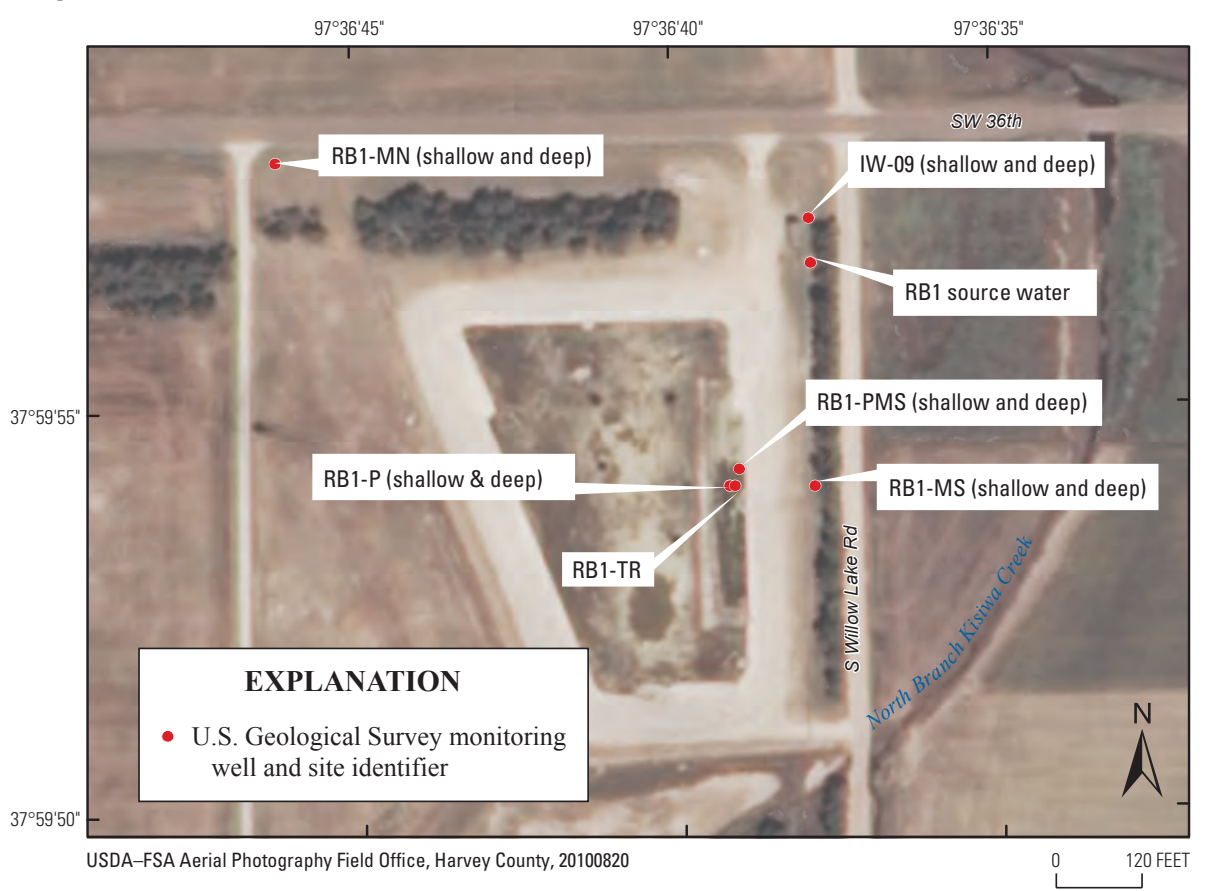

B

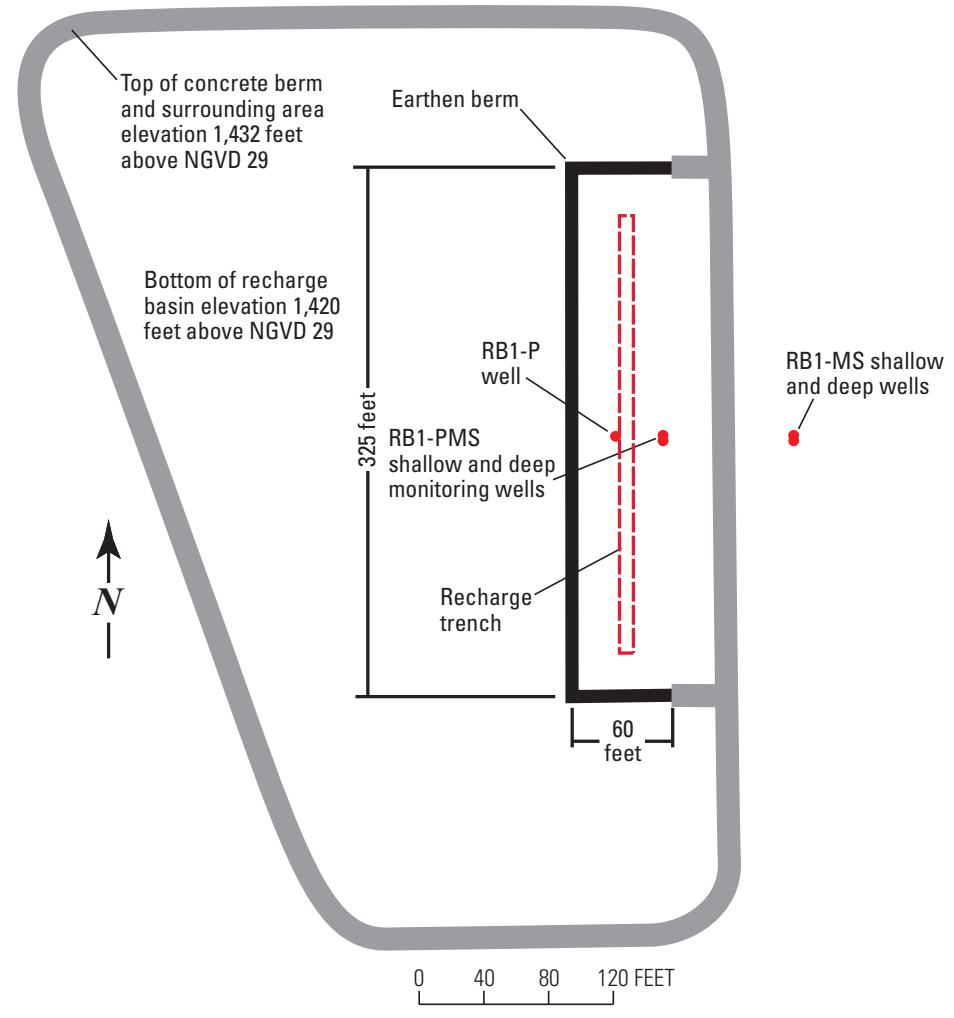

Figure 2. Test site details, including $(A)$ schematic of experimental passive recharge system $(B)$ schematic of RB1 basin and trench, and $(C)$ aerial photo of test site with monitoring well locations. Adapted from drawing D005B, City of Wichita. 


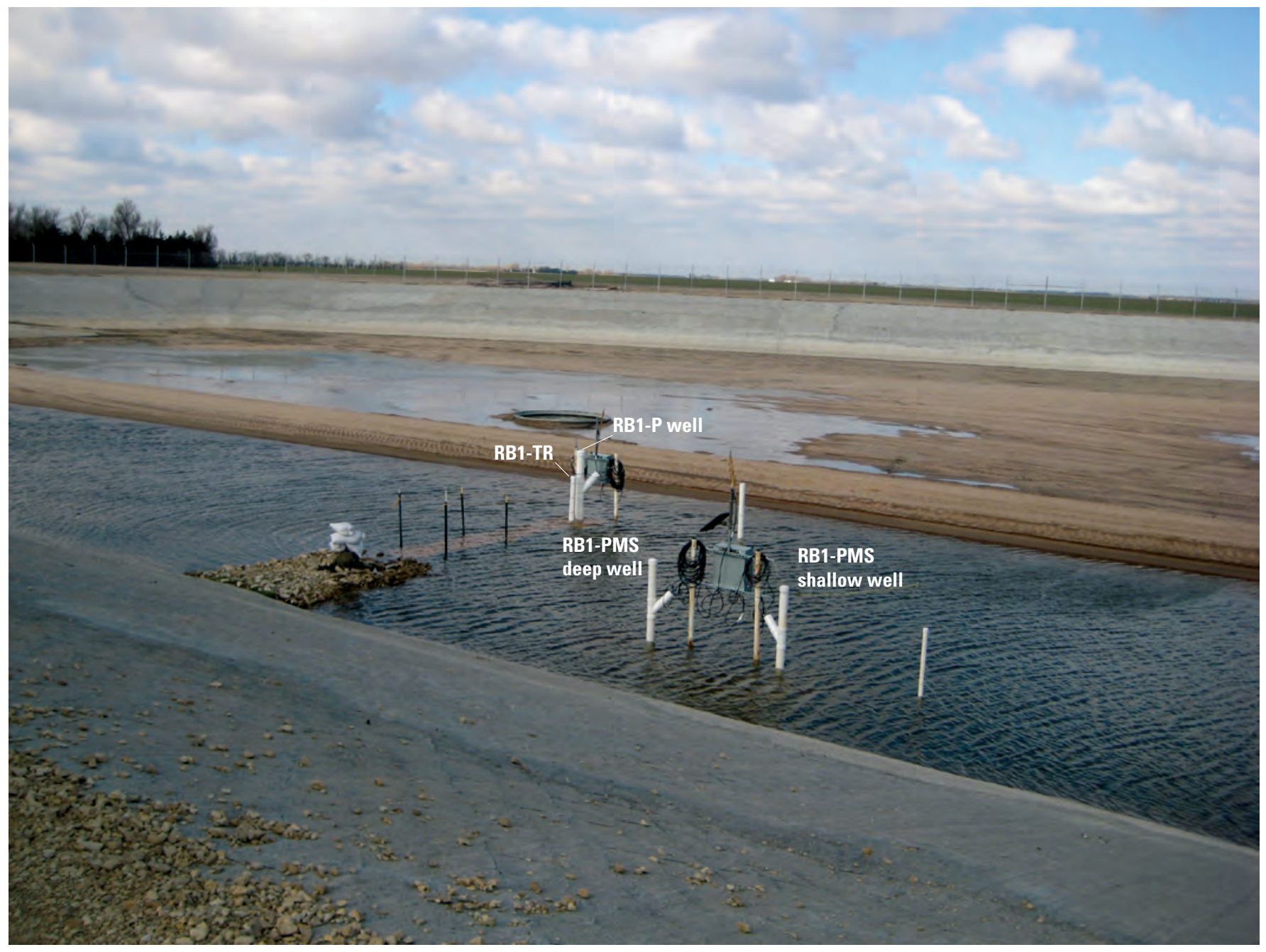

Figure 3. RB1-TR, RB1-P well, and RB1-PMS wells installed along the eastern edge of the original RB1 basin. Photographed from the northeast during artificial recharge when trench was flooded with treated surface water.

\section{Geophysical Logging}

Geophysical logging, including natural gamma radiation and vertical flow rates in the RB1-P well and RB1-PMS shallow and deep wells, was conducted by the USGS Texas Water Science Center during January, 2009. Natural gamma radiation is emitted by rocks surrounding a well borehole. Clay and shale-bearing rocks and sediments tend to be more radioactive than quartz sandstones or carbonates (Keys, 1990). Therefore, the amount of radiation emitted can be helpful in determining lithology in the borehole. The natural gamma sensor (sodium iodide detector) built into the Century Model 8144c multiparameter probe was used to log gamma radiation in the RB1 wells. The natural gamma log was recorded in natural gamma counts per second (CPS). The direction and rate of vertical water flow within the RB1-P well and RB1-PMS wells were measured with a Century Model 9721 electromagnetic (E-M) vertical flowmeter (Molz and others, 1994). Vertical flow, in gal/min, was recorded during ambient and pumped conditions at approximate $10-\mathrm{ft}$ intervals within wellbores. Upward flow is recorded as positive values and downward flow as negative values. A 3-inch submersible pump was used for pumping the RB1-PMS shallow and deep wells, and a 4-inch submersible pump was used for pumping the RB1-P well.

The USGS Wichita Field Office personnel used YSI continuous monitors to measure vertical profiles of temperature and DO under ambient conditions in the RB1-P well and RB1-PMS wells during February 2009. The monitors were lowered into the wellbore and measurements were recorded at 5 or 10 -ft intervals to a depth of approximately $185 \mathrm{ft}$.

\section{Water-Sample Collection}

Discrete water-quality measurements and continuous water-level and real-time water-quality data are used in this report to describe water quality and hydrologic characteristics 
Table 1. Data-collection sites for RB1 passive recharge investigation, south-central Kansas, 2009-2010.

[USGS, U.S. Geological Survey; NAVD 88, National Vertical Datum of 1988; NA, not applicable]

\begin{tabular}{|c|c|c|c|c|c|c|}
\hline $\begin{array}{l}\text { Data-collection } \\
\text { site name } \\
\text { (fig. 2) }\end{array}$ & $\begin{array}{c}\text { USGS } \\
\text { site } \\
\text { identification } \\
\text { number }\end{array}$ & Site name & $\begin{array}{l}\text { Measurement } \\
\text { type used }\end{array}$ & $\begin{array}{l}\text { Gage datum or } \\
\text { altitude of top of } \\
\text { well casing } \\
\text { (feet above } \\
\text { NAVD 88) }\end{array}$ & $\begin{array}{l}\text { Approximate } \\
\text { well } \\
\text { depth } \\
\text { (feet) }\end{array}$ & $\begin{array}{l}\text { Approximate } \\
\text { depth of } \\
\text { screened } \\
\text { interval } \\
\text { (feet) }\end{array}$ \\
\hline \multicolumn{7}{|c|}{ Surface-water sites } \\
\hline 07143672 & 07143672 & $\begin{array}{l}\text { Little Arkansas River at Highway } 50 \text { near Halstead, } \\
\text { Kansas }\end{array}$ & Continuous monitor & $1,370.55$ & NA & NA \\
\hline Diverted SW & 380328097341400 & Diverted SW at PAC building, Burrton, Kansas & Discrete samples & NA & NA & NA \\
\hline \multicolumn{7}{|c|}{ Recharge water } \\
\hline RB1 source water & 375954097363803 & 24S 03W 02AAAA03 RB1 source water & Discrete samples & NA & NA & NA \\
\hline \multicolumn{7}{|c|}{ Groundwater } \\
\hline RB1-TR & 375954097363808 & 24S 03W 02AADA08 RB1-TR & Discrete samples, continuous monitor & $1,420.02$ & NA & NA \\
\hline RB1-P shallow & 375954097363806 & 24S 03W 02AADA06 RB1-P shallow & Discrete samples, continuous monitor & $1,420.02$ & 253 & $20-233$ \\
\hline RB1-P deep & 375954097363807 & 24S 03W 02AADA07 RB1-P deep & Discrete samples, continuous monitor & $1,420.02$ & 253 & $20-233$ \\
\hline RB1-PMS shallow & 375954097363804 & 24S 03W 02AADA04 RB1-PMS shallow & Discrete samples, continuous monitor & $1,420.53$ & 84 & $20-80$ \\
\hline RB1-PMS deep & 375954097363805 & 24S 03W 02AADA05 RB1-PMS deep & Discrete samples, continuous monitor & $1,420.62$ & 247 & $20-243$ \\
\hline RB1-MS shallow & 375954097363801 & 24S 03W 02AADA01 RB1-MS shallow & Discrete samples, continuous monitor & $1,427.00$ & 60 & $50-60$ \\
\hline RB1-MS deep & 375954097363802 & 24S 03W 02AADA02 RB1-MS deep & Discrete samples, continuous monitor & $1,427.00$ & 260 & $240-260$ \\
\hline RB1-MN shallow & 375958097364601 & 24S 03W 02AABB01 RB1-MN shallow & Discrete samples & $1,430.00$ & 60 & $50-60$ \\
\hline RB1-MN deep & 375958097364602 & 24S 03W 02AABB02 RB1-MN deep & Discrete samples & $1,430.00$ & 253 & $233-253$ \\
\hline IW-09 shallow & 375958097363801 & 24S 03W 02AAAA01 IW-09 shallow & Discrete samples & $1,431.70$ & 53 & $33-53$ \\
\hline IW-09 deep & 375958097363802 & 24S 03W 02AAAA02 IW-09 deep & Discrete samples & $1,431.70$ & 255 & $233-253$ \\
\hline
\end{tabular}


in the Equus Beds aquifer at RB1 during and after the passive recharge gravity well test period (January 2009 through March 2010). Water samples and physical measurements were collected from a total of 13 sites during the study period. In addition, 7 of the 13 sites were equipped with continuous real-time water-quality monitors. Rainfall was recorded at the "Little Arkansas River at Highway 50 near Halstead" streamflowgaging station (fig. 1).

\section{Discrete Water-Quality Samples}

As part of this study, discrete water-quality samples were collected from Diverted SW, RB1 source water, and 11 groundwater monitoring sites in and near RB1 (table 1, and fig. 2) during the test period. In previous years, water-quality samples were collected from RB1-MS shallow and deep wells, RB1-MN shallow and deep wells, and IW-09 shallow and deep wells (Ziegler and others, 2010).

Water samples during artificial recharge were collected in sequence on days one and three of the artificial recharge application to follow the flow of the recharge water from the Little Arkansas River (Diverted SW, collected at the PAC Building, Burrton, Kansas), through the treatment plant (RB1 source water), into the trench (RB1-TR), RB1-P well (shallow and deep measurement depths), RB1-PMS wells (shallow and deep), and RB1-MS wells (shallow and deep). Samples were collected on day one and day three of artificial recharge when recharge was occurring. Other wells near the RB1 site, but not in the direct flow of the water, were sampled last (IW-09 shallow and deep, and RB1-MN shallow and deep wells). During water withdrawal the RB1-P well was not directly available because the pump removing water was in the well. Samples labeled RB1-P deep well (during water withdrawal only) were collected from the outflow of the pump. The continuous monitor for the RB1-P deep well was placed in a holding tank to monitor outflow water properties. The RB1-P shallow site was not sampled during water withdrawal.

Surface-water samples were collected using depth- and width-integrating techniques (Wilde and Radtke, 1998).

Groundwater samples were collected with a noncontaminating submersible pump using methods described in Wood (1976), Koterba and others (1995), and Puls and Barcelona (1996). To obtain representative samples, at least three well volumes were purged before sample collection. $\mathrm{SC}, \mathrm{pH}$, water temperature, DO, oxidation-reduction potential (ORP), and turbidity were measured at 5-minute intervals. Water samples were collected after these properties stabilized (within 10 percent for three consecutive readings) and turbidity was less than 10 nephelometric turbidity units (NTUs). Biological activity reaction tests (BART) (described later in this section) were conducted and samples were analyzed for total coliform, fecal coliform and E. coli indicator bacteria at the USGS Wichita Field Office laboratory.

Water samples collected were analyzed for physical properties, major ions, nutrients, dissolved trace elements, and bacterial and viral indicators (see table 4 at the back of this report). Water for analysis of dissolved trace elements was filtered through a 0.45 -micrometer pore size filter. The City of Wichita Municipal Water and Wastewater Laboratory (WWWL) in Wichita, Kansas analyzed samples for physical properties, total dissolved solids, major ions, trace elements, nutrients, indicator bacteria, total suspended solids, and total organic carbon. The USGS Ohio Water Science Center Microbiology Laboratory in Columbus, $\mathrm{OH}$ analyzed samples for $E$. coli F-specific coliphage, E. coli somatic coliphage, and Clostridium perfringens. Methods used to analyze water samples for physical properties and to determine concentrations of dissolved solids, major ions, nutrients, dissolved trace elements, and coliform bacteria were described in Ziegler and Combs (1997). Methods used by the WWWL are described in detail in the City of Wichita Quality Assurance Plan 2010 (City of Wichita, written commun., 2011). Fecal and viral indicator bacteria analyses were done using methods described by Bisson and Cabelli (1979, 1980), Britton and Greeson (1987), Armon and Payment (1988), Payment and Franco (1993), and United States Environmental Protection Agency (1996, 2000, 2001a, 2006b-e). Methods used to analyze BART are described by Droycon Bioconcepts, Inc. (2004). The U.S. Geological Survey (USGS) Organic Geochemistry Research Laboratory, Lawrence, Kansas analyzed samples for atrazine using the enzyme-linked immunosorbent assay (ELISA) (Thurman and others, 1990). For the purposes of this report, dissolved triazine compounds detected by ELISA are referred to as atrazine. Samples for analyses of suspended sediment concentration (SSC) in surface water were sent to the USGS Sediment Laboratory in Iowa City, IA (Guy, 1969).

Several methods were used to quantify bacteria in water samples. Membrane filtration methods using M-Endo culture medium have historical reliability, but newer methods, including the defined substrate technology (Colilert Quantitray) methods and newer culture media (M-ColiBlue) for the traditional membrane filtration test offer some advantages. For example, bacteria that are stressed or injured are more likely to be effectively cultured by defined substrate technology tests (Covert and others, 1992; McFeters, 1993; McFeters and others, 1995), and the M-ColiBlue culture medium has been documented to be effective in suppressing the growth of background bacteria as well as successfully culturing stressed organisms, producing more accurate coliform counts (Hamilton and others, 2005; Wang and Fiessel, 2008). The USGS Wichita Field Office used a membrane filtration method with M-Endo and M-ColiBlue culture plates to measure total coliform, membrane filtration with M-FC medium to measure fecal coliform, and a modified m-TEC membrane filtration method to measure E. coli. The City of Wichita Municipal Water and Wastewater Laboratory (WWWL) used Standard LES Endo Method and Colilert Quantitray methods to test for total coliform, membrane filtration with M-FC medium to test for fecal coliform, and Colilert Quantitray method to measure counts of E. coli. Methods used by the WWWL are described 
in detail in the City of Wichita Quality Assurance Plan 2010 (City of Wichita, written commun., 2011).

The Biological Activity Reaction Test (BART) for ironrelated bacteria and sulfate-reducing bacteria, manufactured by Droycon Bioconcepts Inc., were used to evaluate the potential for plugging of the aquifer material and well fouling by iron-related and sulfate-reducing bacteria. The BART provides a semi-quantitative assessment of the select bacterial community in the water sample. The BART uses a bacteria-specific nutrient medium in combination with a floating intercedent device (FID) that acts as a barrier to oxygen diffusion into the sample, creating at least three distinct environments for bacterial growth. Above the FID, growth of aerobic bacteria occurs in the oxygen-rich environment; beneath the FID growth of anaerobic bacteria occurs in the anoxic environment; and at the interface of the two environments, facultative anaerobes grow at the oxidation-reduction (redox) front. The IRB-BART (Iron Related Bacteria Biological Activity Reaction Test) uses a ferric-iron nutrient media for select growth of iron-related bacteria and the SRB-BART (Sulfate Reducing Bacteria Biological Activity Reaction Test) uses a short-chain fatty-acid culture medium for the growth of sulfate-reducing bacteria. Distinct reactions defined by color and other visual properties indicate the type of bacteria present in the water sample. The order in which these reactions occur (reaction pattern signature) and the time to the first reaction indicate which bacteria are dominant and provide an estimate of the number of bacteria in the water sample.

In addition to the summary data presented in this report, data for individual sample analyses are available on the World Wide Web at http://waterdata.usgs.gov/ks/nwis/qw.

\section{Continuous Water-Quality Monitoring}

RB1-TR, RB1-P well (shallow and deep monitoring depths), RB1-PMS shallow and deep wells, and RB1-MS shallow and deep wells were equipped with multi-sensor water-quality monitors to continuously measure physical properties including water temperature, water altitude, $\mathrm{SC}, \mathrm{pH}$, DO, and ORP. In addition, monitors in RB1-TR, the RB1-P well (shallow and deep monitoring depths), and the RB1-PMS wells continuously monitored turbidity measurements. The sensors were calibrated and maintained according to methods presented in Wilde and Radke (1998) and Wagner and others (2006). Measurements from continuous monitoring sensors were checked against a calibrated field meter during site visits. These data were transmitted by satellite to a computer at the USGS Kansas Water Science Center. Real-time data are available on request.

Cristensen and others (2003) used continuous monitoring data and discrete measurements of constituents in the Little Arkansas River at Highway 50 near Halstead to develop site-specific equations relating SC or turbidity to constituent concentration. Water for artificial recharge at the RB1 site was diverted from the Little Arkansas River near USGS site 07143672 . For this study, estimates of chloride concentration in recharge water are calculated from continuous specific conductance measurements at this site according to equation 1 :

$$
C l=-33.7+0.209 S C
$$

where:

$$
\begin{aligned}
& \mathrm{Cl} \text { is the concentration of chloride in } \mathrm{mg} / \mathrm{L} \text {; and } \\
& \mathrm{SC} \quad \text { is specific conductance measured in } \\
& \text { microsiemens per centimeter at } 25^{\circ} \mathrm{C} \text {. }
\end{aligned}
$$

\section{Quality Assurance and Quality Control}

Replicate, blank, and standard reference samples were analyzed as a part of quality assurance/quality control (QA/ QC) measures for the RB1project. QA samples were collected according to protocols in the National Field Manual for the Collection of Water-Quality Data (U.S. Geological Survey, 2006). Quality-assurance and quality-control procedures outlined in "Baseline Data-Collection and Quality-Control Protocols and Procedures for the Equus Beds Ground-Water Recharge Demonstration Project near Wichita, Kansas, 1995-96" (Ziegler and Combs, 1997) and the written communication "Quality-Assurance Plan for the Water-Quality Activities by the U.S. Geological Survey in Kansas, 2008" were followed for sample collection protocols.

All types of replicate samples were analyzed using the relative percent difference between the environmental sample and the replicate sample. The precision of the replicate analysis is defined by equation 2 :

$$
R P D=\frac{\left(C_{1}-C_{2}\right) \times 100}{\frac{\left(C_{1}-C_{2}\right)}{2}}
$$

where:

$$
\begin{aligned}
& R P D \quad \text { is relative percentage difference; } \\
& C_{1} \text { is the larger of two concentration values from } \\
& \text { the environmental or replicate sample; and } \\
& \mathrm{C}_{2} \quad \text { is the smaller of two concentration values } \\
& \text { from the environmental or replicate sample } \\
& \text { (Ziegler and Combs, 1997). }
\end{aligned}
$$

For inorganic constituents, an onsite or laboratory replicate $R P D$ within 10 percent was acceptable (Ziegler and Combs, 1997). For organic constituents and bacterial analysis, a replicate analytical result within 20 and 50 percent, respectively, was acceptable.

A summary of the analysis of replicate pairs collected from 2009 through March 2010 at RB1 sites is presented in table 2. Thirty-nine of 52 constituents had no relative percent differences (RPD's) greater than the acceptable limit. Chloride, sulfate, nitrate, phosphorus, iron, and manganese all had $R P D$ 's more than 10 percent in one out of 7 replicate pairs. Two of 7 replicate pairs analyzed for ammonia, nitrite, and 
orthophosphate had $R P D$ 's more than the acceptable limit. Five of 12 pairs analyzed for triazine had RPD's greater than 20 percent. One of 5 pairs analyzed for fecal coliform, as well as one out of 8 pairs analyzed for coliphage had RPD's above 50 percent.

A summary of results from blank samples is presented in table 3. Twenty-one of 28 analyzed constituents were not detected in blank samples. Seven blanks were tested for organic carbon, and three detections with concentrations of $0.38,0.21$, and $0.33 \mathrm{mg} / \mathrm{L}$ were made. Alkalinity was detected in seven out of eight blanks, and bicarbonate was detected in eight out of eight. The detections of alkalinity and bicarbonate were small and can be attributed to exposure of the blank samples to carbon dioxide in the atmosphere. E. coli and fecal coliform were each detected in two of four blank samples. All four detections of $E$. coli were $1 \mathrm{CFU} / 100 \mathrm{~mL}$. Turbidity was detected in three blank samples $(0.2,0.16$, and 0.44 NTRU).

Standard reference water samples are used to determine the bias and variability associated with field-handling, shipping, and laboratory procedures (U.S. Geological Survey, 2006). A reference sample is a laboratory-prepared solution whose composition is certified for one or more properties so that it can be used to assess a measurement method (U.S. Geological Survey, 2006). The reference samples are typically submitted as blind samples to the laboratory and the concentration of the samples is known. The accuracy for standard reference samples is measured by equation 3 :

$$
\text { Percentage Recovery }=\left(C_{\text {measured }} \div C_{\text {actual }}\right) \times 100 \text { percent (3) }
$$

where:

$$
\begin{gathered}
C_{\text {measured }} \\
\text { is the measured concentration of the } \\
\text { constituent; and } \\
C_{\text {actual }} \\
\text { is the most probable value (MPV) of the } \\
\text { constituent concentration. }
\end{gathered}
$$

Two blind standard reference samples were submitted and analyzed as part of the RB1 project using standard references M-186 (U.S. Geological Survey, 2008a), T-193 (U.S. Geological Survey, 2008a), and N-99 (U.S. Geological Survey, 2008b). One blind sample was analyzed for $\mathrm{pH}$ and specific conductance. Both measurements were within acceptable range of percent recovery (80-120 percent). The other blind sample was analyzed for 17 constituents. Of those 17, there were 13 within the acceptable range of percent recovery. Chloride, fluoride, and sulfate were not detected, but the MPV was above the minimum reporting level. Ammonia had a percent recovery of 167 percent.

An ion balance was performed on all samples analyzed for major ions. The equation used to evaluate the error in the anion - cation balance is:

$$
C B E=((T C-T A) /(T C+T A)) * 100 \text { percent }
$$

where:

$C B E$ is the charge balance error;
$T C$
is the total cation equivalent weight in milliequivalents per liter (meq/L); and
$T A$ is the total anion equivalent weight in $\mathrm{meq} / \mathrm{L}$.

A $C B E$ of 7 percent or less is considered acceptable in this study. The $C B E$ on samples collected for the RB1 project were 7 percent or less for all samples except one. The sample collected from the RB1-PMS deep site on July 8, 2009 had a $C B E$ of 12.3 percent. QA/QC data are available on request from the USGS, Lawrence, Kansas. The USGS Organic Geochemistry Research Laboratory, Lawrence, Kansas conducted a triazine herbicide screen on submitted samples. The ELISA method was used to screen samples for triazine herbicides in the study described in this report. Approximately 15 percent of samples collected as part of this study were also analyzed by the gas chromatography/ mass spectrometry (GC/MS) method for quality assurance. A linear regression of the data from this study indicates that a best fit line relates the two analysis methods with the equation:

$$
y=1.08 x
$$

where:

$$
\begin{aligned}
& x \quad \text { is the triazine herbicide concentration from } \\
& \text { ELISA, in micrograms per liter; and } \\
& y \quad \text { is the atrazine concentration from GC/MS, in } \\
& \text { micrograms per liter. }
\end{aligned}
$$

A previous study (Ziegler and others, 1999) using samples from the Little Arkansas River reported that for surfacewater samples atrazine (detected by GC/MS) made up 81 percent of the triazine compound concentrations detected by ELISA. (Atrazine: GC/MS $=0.81$ * Triazine: ELISA; Ziegler and others, 1999)

\section{Geochemical Modeling}

The purpose of geochemical modeling is to monitor changes in the water chemistry as a result of artificial recharge and water removal at the RB1 site. Changes in water chemistry might result in the precipitation or dissolution of minerals. Mineral precipitation may cause some aquifer pores to clog and mineral dissolution may release harmful constituents like arsenic into the aquifer.

PHREEQC (Parkhurst and Appelo, 1999) geochemical modeling software was used to calculate saturation indices. The program performs a large variety of low-temperature aqueous geochemical calculations including speciation and saturation index calculations. Data input to PHREEQC included water temperature, $\mathrm{DO}$ concentration, $\mathrm{pH}$, alkalinity, and dissolved concentrations of calcium, magnesium, sodium, potassium, chloride, sulfate, nitrite, nitrate, orthophosphate, fluoride, silica, arsenic, iron, and manganese. The program calculated the oxidation-reduction potential (pe) of the solution based on the nitrate/nitrite oxidation-reduction 
Table 2. Summary of replicate pairs analyzed as part of the Equus Beds Passive Recharge Project at RB1.

[E. coli, Escherichia coli; C13, E. coli culture resistant to naladixic acid and used to detect somatic coliphages; Famp, E. coli culture resistant to ampicillin and streptomycin and used to detect male-specific coliphages; M-FC, membrane method fecal coliform; MF, membrane filter; LES Endo method, membrane Endo agar Lawrence Experiment Station]

\begin{tabular}{|c|c|c|}
\hline Constituent & $\begin{array}{l}\text { Number } \\
\text { of pairs }\end{array}$ & $\begin{array}{c}\text { Percent of pairs } \\
\text { over limit }\end{array}$ \\
\hline Carbonate hardness, water, unfiltered & 5 & 0 \\
\hline Hardness, water & 7 & 0 \\
\hline Calcium, water, filtered & 6 & 0 \\
\hline Magnesium, water & 7 & 0 \\
\hline Potassium, water, filtered & 7 & 0 \\
\hline Sodium, water, filtered & 7 & 0 \\
\hline Alkalinity, water, filtered & 5 & 0 \\
\hline Bicarbonate, water, filtered & 5 & 0 \\
\hline Carbonate, water, filtered & 5 & 0 \\
\hline Bromide, water, filtered & 5 & 0 \\
\hline Chloride, water, filtered & 7 & 14 \\
\hline Fluoride, water, filtered & 7 & 0 \\
\hline Sulfate, water, filtered & 7 & 14 \\
\hline Residue on evaporation & 7 & 0 \\
\hline Residue, total nonfilterable & 5 & 0 \\
\hline Ammonia, water, filtered & 7 & 29 \\
\hline Nitrate plus nitrite, water, filtered & 7 & 0 \\
\hline Nitrate, water, filtered & 7 & 14 \\
\hline Nitrite, water, filtered & 7 & 29 \\
\hline Orthophosphate, water, filtered & 7 & 29 \\
\hline Phosphorus, water, filtered & 7 & 14 \\
\hline Organic carbon, water, unfiltered & 6 & 33 \\
\hline Clostridium perfringens & 4 & 0 \\
\hline Coliphage, E. coli, C13 host & 4 & 0 \\
\hline Coliphage, E. coli, Famp host & 4 & 25 \\
\hline Fecal coliform, M-FC MF (0.7 micron) method & 5 & 20 \\
\hline Total coliform, LES Endo method & 4 & 0 \\
\hline Aluminum, water, filtered & 1 & 0 \\
\hline Antimony, water, filtered & 1 & 0 \\
\hline Arsenic, water, filtered & 6 & 0 \\
\hline Barium, water, filtered & 1 & 0 \\
\hline Beryllium, water, filtered & 1 & 0 \\
\hline Boron, water, filtered & 1 & 0 \\
\hline Cadmium, water, filtered & 1 & 0 \\
\hline Chromium, water, filtered & 1 & 0 \\
\hline Copper, water, filtered & 1 & 0 \\
\hline Cyanide, water, filtered & 1 & 0 \\
\hline Iron, water, filtered & 7 & 14 \\
\hline Lead, water, filtered & 1 & 0 \\
\hline Manganese, water, filtered & 7 & 14 \\
\hline Mercury, water, filtered & 1 & 0 \\
\hline Nickel, water, filtered & 1 & 0 \\
\hline Selenium, water, filtered & 1 & 0 \\
\hline Silver, water, filtered & 1 & 0 \\
\hline Strontium, water, filtered & 1 & 100 \\
\hline Thallium, water, filtered & 1 & 0 \\
\hline Vanadium, water, filtered & 1 & 0 \\
\hline Zinc, water, filtered & 1 & 0 \\
\hline Atrazine, water, filtered & 3 & 0 \\
\hline Triazine screen, water, filtered & 12 & 42 \\
\hline Alpha radioactivity, water, filtered & 1 & 100 \\
\hline Gross beta radioactivity, water, filtered & 1 & 0 \\
\hline
\end{tabular}


Table 3. Summary of blank samples analyzed as part of the Equus Beds Passive Recharge Project at RB1.

[m-TEC, membrane-thermotolerant Escherichia coli; MF, membrane filter; M-FC, membrane method fecal coliform]

\begin{tabular}{lcc}
\hline \multicolumn{1}{c}{ Constituent } & $\begin{array}{c}\text { Number of blank } \\
\text { samples }\end{array}$ & $\begin{array}{c}\text { Number } \\
\text { of detections }\end{array}$ \\
\hline Turbidity, water, unfiltered & 3 & 3 \\
Carbonate hardness, water, unfiltered & 8 & 0 \\
Dissolved solids dried at 180 degrees Celsius, water, filtered, & 8 & 0 \\
Suspended solids, water, unfiltered & 7 & 0 \\
Calcium, water, filtered & 8 & 0 \\
Magnesium, water, filtered & 8 & 0 \\
Potassium, water, filtered & 8 & 0 \\
Sodium, water, filtered & 8 & 0 \\
Alkalinity, water, filtered & 8 & 7 \\
Bicarbonate, water, filtered & 8 & 8 \\
Bromide, water, filtered & 8 & 0 \\
Carbonate, water, filtered & 8 & 0 \\
Chloride, water, filtered & 8 & 0 \\
Fluoride, water, filtered & 8 & 0 \\
Sulfate, water, filtered & 8 & 0 \\
Ammonia, water, filtered & 8 & 0 \\
Nitrate plus nitrite, water, filtered & 8 & 0 \\
Nitrate, water, filtered & 8 & 0 \\
Nitrite, water, filtered & 8 & 0 \\
Orthophosphate, water, filtered & 8 & 0 \\
Phosphorus, water, filtered & 8 & 0 \\
Escherichia coli, modified m-TEC MF method, water & 4 & 2 \\
Fecal coliform, M-FC MF (0.7 micron) method, water & 4 & 2 \\
Iron, water, filtered & 8 & 0 \\
Manganese, water, filtered & 8 & 0 \\
Arsenic, water, filtered & 8 & 1 \\
Triazine screen, water, filtered, & 8 & 0 \\
Organic carbon, water, unfiltered & 7 & 3 \\
\hline
\end{tabular}

pair. Concentrations below reporting levels were input as the reporting level value.

The saturation index $(S I)$ indicates the extent of disequilibrium of a solution with respect to a mineral. A positive saturation index indicates the solution is oversaturated with respect to a mineral, and there is potential for the mineral to precipitate. Conversely, a negative saturation index indicates the solution to be undersaturated with respect to a mineral, and there is potential for the mineral to dissolve if it is present (Ross Schmidt and others, 2007). Saturation indices, though, are a result of equilibrium calculations and only indicate solubility constraints. Dissolution or precipitation kinetics, along with competition amongst species present in the water, also affect whether dissolution or precipitation actually occurs.

The SI is the log of the ion-activity product of a solution divided by the solubility product $\left(K_{s p}\right)$. For example, the saturation index equation for calcite $\left(\mathrm{CaCO}_{3}\right)$ is:

$$
S I=\log \frac{\left[\mathrm{Ca}^{2+}\right]\left[\mathrm{CO}_{3}^{2-}\right]}{K_{s p(\text { calcite })}}
$$

where:

$\left[\mathrm{Ca}^{2+}\right]$ is the activity of the calcium ion;

$\left[\mathrm{CO}_{3}{ }^{2-}\right]$ is the activity of the carbonate ion; and

$K_{s p \text { (calcite) }} \quad$ is the solubility product of calcite.

Though neither pe nor $\mathrm{pH}$ is included in the numerator of the $S I$ calculation, both can have a substantial effect on the $S I$. For example, in the $S I$ calculation for carbonate, the activity of the carbonate ion is $\mathrm{pH}$ and concentration dependent. In the SI calculation for other minerals with redox-active elements like iron, manganese, and arsenic, the activity of redox-active element is pe and concentration dependent.

Saturation indices were calculated for all water samples during the study period. Calcium, iron, manganese, and arsenic are present in the aquifer and have been determined 
to be constituents of concern in previous studies but they frequently exceeded USEPA drinking water criteria (Ross Schmidt and others, 2007; Ziegler and others, 2010). Monitoring saturation indices for minerals containing these elements provides information on whether passive recharge and water removal affected the water chemistry with respect to calcium, iron, manganese, and arsenic. The minerals for which saturation indices are reported here are calcite $\left(\mathrm{CaCO}_{3}\right)$, iron hydroxide $\left(\mathrm{Fe}_{3}(\mathrm{OH})_{8}\right)$, manganite $(\mathrm{MnOOH})$, and scorodite $\left(\mathrm{FeAsO}_{4}: 2 \mathrm{H}_{2} \mathrm{O}\right)$. These were chosen to illustrate the changes in water chemistry with respect to major aquifer constituents in the study period.

\section{Water Quantity}

\section{Hydrogeology}

Borehole geophysical data consisting of natural gamma radiation collected in the RB1-P well and RB1-PMS wells, and vertical flow rates under ambient and pumped conditions in the RB1-P well were collected in January 2009. Gamma radiation logs indicate the presence of a lithologic layer with comparatively greater gamma radiation from 50 to $60 \mathrm{ft}$ below ground surface (fig. $4 A$ ). This is interpreted as indicating the

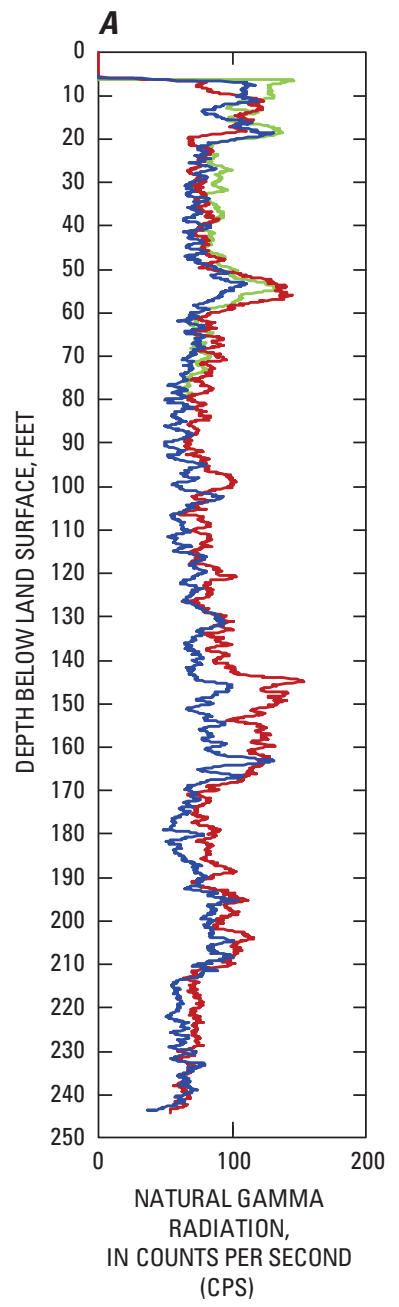

B

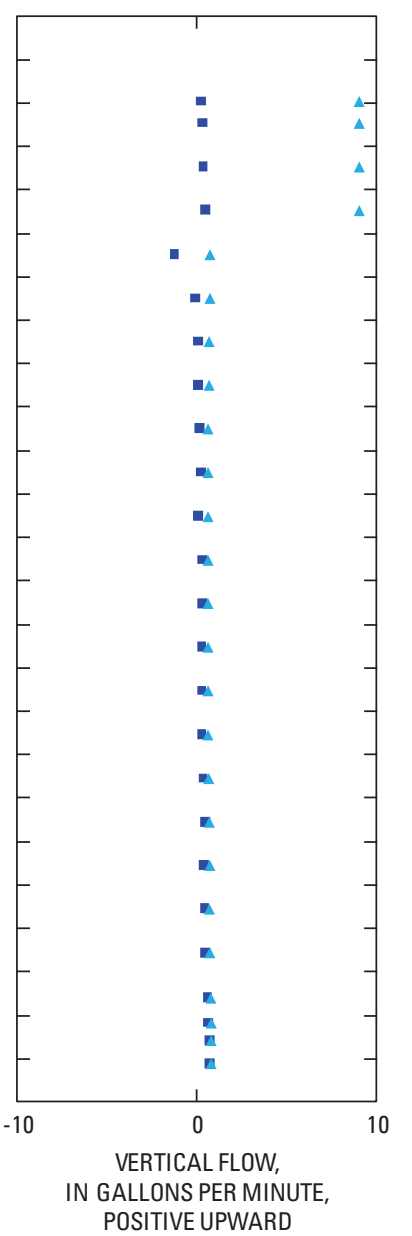

C

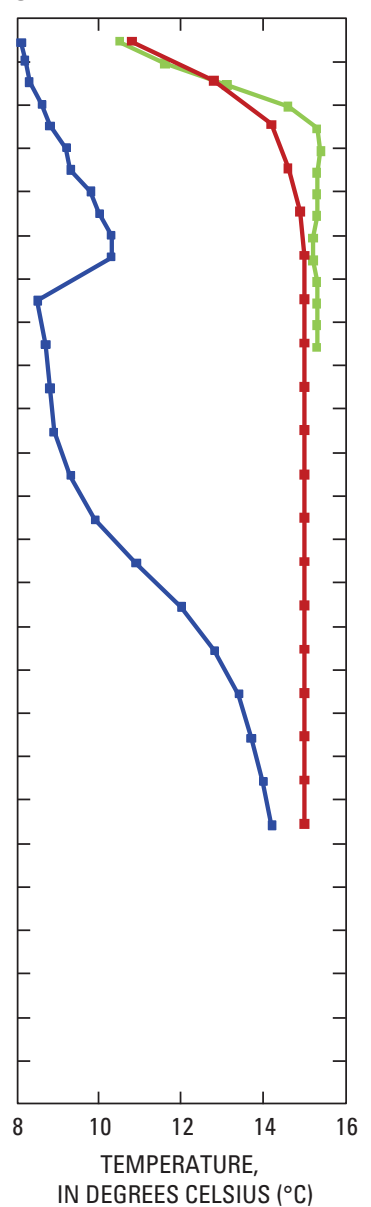

D

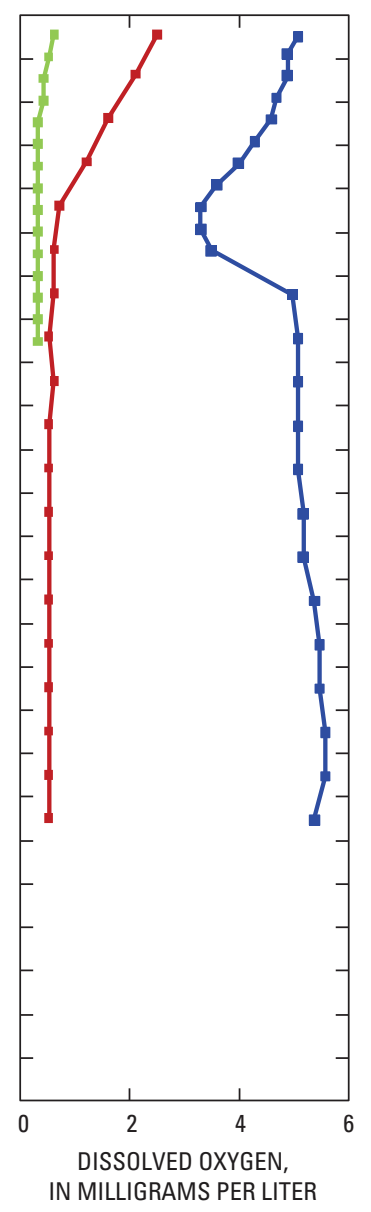

EXPLANATION

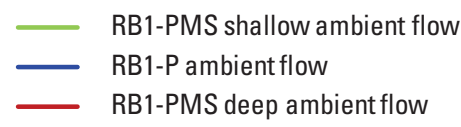

$\triangle \quad$ RB1-P pumped flow

- RB1-P ambient flow RB1-PMS deep ambient flow

Figure 4. Borehole geophysical logs of $(A)$ natural gamma radiation in RB1-P well and RB1-PMS shallow and deep wells $(B)$ vertical flow in RB1-P well under ambient and pumped flow conditions $(C)$ temperature in RB1-P well and RB1-PMS shallow and deep wells $(D)$ dissolved oxygen in RB1-P well and RB1-PMS shallow and deeps wells, before artificial recharge. 
presence of a layer with a large amount of clay content (Keys, 1990; G. Stanton, USGS, written commun., 2011). Vertical flowmeter measurements collected in the RB1-P well under ambient conditions shift from small upward or no-flow conditions at a depth of approximately $45 \mathrm{ft}$ to downward flow of approximately $1.2 \mathrm{gal} / \mathrm{min}$ at a depth of $55 \mathrm{ft}$, indicating that water is entering the wellbore at this location (Paillet, 2001; G. Stanton, USGS, written commun., 2011). Because water flows from high hydraulic head to low hydraulic head, the zone of inflow can be interpreted as a zone of higher hydraulic head. Vertical flowmeter measurements shift from downward flow of approximately $1.2 \mathrm{gal} / \mathrm{min}$ at a depth of $55 \mathrm{ft}$ to no flow conditions at a depth of approximately $65 \mathrm{ft}$, indicating that water is leaving the wellbore at this location. Pumped conditions in the RB1-P well were achieved by setting the submersible pump in the borehole at approximately $11 \mathrm{ft}$ below land surface. The pump discharged approximately $9 \mathrm{gal} / \mathrm{min}$ at the surface. During pumping, all flow in the RB1-P well measured by the vertical flowmeter was upward. From depths of 244 to 55 feet below land surface the upward flow was small ( 0.6 to $0.7 \mathrm{gal} / \mathrm{min}$ ). Between depths of 55 and $45 \mathrm{ft}$ below land surface the flow increases to approximately $9 \mathrm{gal} / \mathrm{minute}$, indicating a zone of larger hydraulic conductivity compared to the depth interval from 244 to $55 \mathrm{ft}$ below land surface is present at that depth (fig. 4B).

YSI continuous monitors were used to measure vertical profiles of temperature and DO in the RB1-P well and RB1PMS wells on February 11 and 12, 2009, before recharge began. Although artificial recharge water was not being pumped into the system, the RB1-P well was connected to the trench, and water from precipitation was able to infiltrate into the system. In the RB1-PMS shallow and deep wells, water temperature increased with depth in the shallow aquifer and then stabilized, as would be expected during winter months. However, the temperature in the RB1-P well increased until about $55 \mathrm{ft}$ below the surface, decreased for about $10 \mathrm{ft}$, and then increased again. Water temperature in the RB1-P well was less than that in the RB1-PMS wells because of cold water infiltrating from the surface (fig. $4 \mathrm{C}$ ). As indicated by vertical flowmeter measurements, groundwater (with a slightly greater temperature) enters the wellbore near a depth of $50 \mathrm{ft}$, and is reflected in the temperature profile of the RB1-P well. Profiles of DO also change rapidly in the upper $50 \mathrm{ft}$ of the aquifer (all three wells) with an inversion from 50 to $65 \mathrm{ft}$ in the RB1-P well only (fig. 4D). The RB1-PMS wells are not connected directly to the trench system and, when the profile was measured, represent conditions in the aquifer before artificial recharge began. Because the RB1-P well was connected to the surface through the trench system, small amounts of oxygenated surface water entered the well resulting in large DO values near the surface and throughout the well in general. Near a depth of $50 \mathrm{ft}$, water flowed into the RB1-P well from areas in the aquifer that have smaller amounts of DO. The RB1-P well temperature and DO profiles indicate that artificial recharge from the surface is occurring and water is flowing down into the deep aquifer. The decrease in temperature and increase in DO below a depth of $55 \mathrm{ft}$ in the RB1-P well indicate that some cold, oxygen-rich surface water is flowing downward from the surface into the deep aquifer even though an area of higher head exists near a depth of $50 \mathrm{ft}$.

\section{Water-Level Altitude from Continuous Monitors}

Water-level altitude recorded by continuous monitors at RB1 sites is shown on figure $5 \mathrm{~A}$. Water-level altitude in RB1-MS deep fluctuated between about 1,405 and 1,409 ft in February and March 2009 before artificial recharge began. Changes in altitude in the RB1-MS deep well were large and occurred quickly, indicating the change resulted from pumping from the aquifer at a nearby location. The water-level altitude in the RB1-MS shallow well did not change with the altitude of the RB1-MS deep well and remained nearly constant at about $1,416.5 \mathrm{ft}$ before artificial recharge.

Water-level measurements recorded by the continuous monitors indicate an increase in water-level altitude in the RB1-P well (4.5 ft) when recharge water entered the system. A rise in RB1-P well water-level altitude occurred during artificial recharge but a smaller rise in altitude also occurred with rainfall events indicating that water was entering the system as a result of artificial recharge and rainfall. During May and June, when artificial recharge was not occurring, rainfall caused several small rises in the water-level altitude in the RB1-P well. Enough precipitation fell into the RB1 basin to raise the water level in the RB1-P well above the trench floor $(1,420.0 \mathrm{ft}$ on at least seven occasions in May and June, 2009 (fig. 5A)).

Water-level altitude in the RB1-PMS shallow and RB1PMS deep wells were similar throughout the test because wells are screened above and below the clay layer near $50-\mathrm{ft}$ depth, which separates the upper and lower parts of the aquifer at RB1. Water levels in the RB1-PMS shallow well and the RB1-MS shallow well rose by 0.1 to $0.25 \mathrm{ft}$ when water entered the system through the RB1-P well and increased by about $1 \mathrm{ft}$ total during the period of passive recharge (April 1 through June 30). The increase in water-level altitude in the RB1-PMS wells and RB1-MS shallow well during recharge decreases the west to east hydraulic gradient, and slows the eastward migration of saltwater from the Burrton oil-field disposal site.

Water levels in the RB1-MS shallow well were generally 0.3 to $0.5 \mathrm{ft}$ higher than those in the RB1-PMS shallow well because the wells are screened at different depths, but changes in water-level altitude were similar. The screened interval for the RB1-MS shallow well included the depth interval with the high hydraulic head area discussed in the "Hydrogeology" section of this report. The RB1-MS deep well was connected only to a deeper part of the aquifer and indicates the lower hydraulic head values associated with the deeper part of the aquifer. Because the RB1-P well is screened from 20 to $233 \mathrm{ft}$, water entering through the RB1-P well will tend to flow downward to the lower parts of the well (and aquifer). Recharge water 
entering the system may affect the lower parts of the aquifer more than the upper parts of the aquifer.

After installation of the passive recharge system, recharge water flowed through the sand filled filtration trench and entered the aquifer through the 6-inch passive gravity recharge well at a rate of 15 to $25 \mathrm{gal} / \mathrm{min}$ (R. Robinson, City of Wichita, written commun., 2010). Using the average recharge rate of $20 \mathrm{gal} / \mathrm{min}$ within the trench area of about 1,500 $\mathrm{ft}^{2}$, the recharge for the trench and passive well system is about $19.2(\mathrm{gal} / \mathrm{d}) / \mathrm{ft}^{2}$, about 78 percent greater than the original recharge rate.

\section{Water Quality}

\section{Physical Properties}

\section{Water-Quality Monitor Data}

Turbidity in surface water has been strongly correlated to E. coli bacteria concentration because bacteria readily attach to the sediment particles (Rasmussen and Ziegler, 2003). Turbidity in groundwater is generally less than 1 Formazin Nephelometric Unit (FNU) because the rate of groundwater flow is insufficient to keep particles in suspension. Large turbidity values may indicate that bacteria was entering or was present in the RB1 system. Turbidity values of 10-140 FNU were recorded during and immediately after the RB1-P and the RB1-PMS well profiling February 11-13, 2009, and are not representative of normal turbidity values in the wells (fig. 5B). Continuous monitors recorded increased turbidity values in RB1-TR and the RB1-P well (shallow and deep monitoring depths) during and after rainfall events and during artificial recharge. The increase in turbidity during rainfall events was likely caused by the suspension of small sediment particles in recharge water as the water passed through the trench sands which contained sand, silt, and clay-sized particles (see Feb 2009, fig. 5C). Continuous monitors recorded increased turbidity values in RB1-TR and RB1-P well (shallow and deep monitoring depths) during artificial recharge, especially the first few hours. After several hours of artificial recharge, suspended particles are deposited on the existing aquifer material and turbidity values in RB1-TR and RB1-P well (shallow and deep monitoring depths) were similar to those measured in the RB1 source water. During May and June 2009, turbidity values increased slightly in response to rain events.

A spike in turbidity in the RB1-P well (deep monitoring depth) coincided with the date the monitor was removed from the well and placed in a tank to take measurements in water being pumped out of the aquifer. After the passive recharge system was disconnected (July 8, 2009) and water was no longer flowing into the RB1-P well from the trench, turbidity levels were small. A small increase in turbidity in the RB1-P well (deep monitoring depth) occurred in early October when monitors were removed for checking and calibration, and was because of the disturbance of aquifer sediment rather than the inflow of turbid water from the surface.

$\mathrm{SC}$ is a measure of the ability of a substance to conduct electricity (Hem, 1992). A larger SC indicates a larger amount of ions in solution (a larger amount of dissolved solids). Rainfall has small SC relative to groundwater, so SC can act as a tracer for rainwater that entered the RB1 recharge system, and thus can provide information about the speed and direction of groundwater flow in the RB1 recharge system. SC measurements in RB1-TR, RB1-P well (shallow and deep monitoring depths), RB1-PMS shallow and deep wells, and RB1-MS shallow and deep wells as recorded by continuous monitors, and discrete measurements of SC in RB1 source water are shown in figure $5 C$. SC in RB1-TR, the RB1-P shallow, and the RB1-P deep wells quickly decreased by as much as 500 microsiemens per centimeter at 25 degrees Celsius $(\mu \mathrm{S} / \mathrm{cm})$ immediately after precipitation events (for example March 7, April 12, April 26, April 27, and May 8). On some occasions, when artificial recharge was not occurring, but rainfall was infiltrating, RB1-PMS shallow and deep well monitors recorded a decrease in specific conductance about 3 days after the decrease recorded in RB1-TR and RB1-P well, supporting the hypothesis that water was entering the shallow and deep parts of the RB1-P well from the trench and was moving downgradient to the east at a rate of about 10 feet per day. Continuous monitors in RB1-TR and the RB1-P well (shallow and deep monitoring depths) recorded an increase in specific conductance to concentrations similar to that of the RB1 source water immediately after artificial recharge, again illustrating the flow of water from RB1-TR, through the RB1-P well, and into the aquifer. In general, $\mathrm{SC}$ values in the RB1-MS shallow well were near $500 \mu \mathrm{S} / \mathrm{cm}$ throughout the study period. SC values in the RB1-MS deep well fluctuated between about $500 \mu \mathrm{S} / \mathrm{cm}$ and $700 \mu \mathrm{S} / \mathrm{cm}$, but these changes do not appear to be associated with rainfall or artificial recharge with treated surface water. $\mathrm{SC}$ values in the RB1-PMS deep well were consistently greater than those in the RB1-PMS shallow well and also decreased after rainfall events. During water withdrawal, SC values in the RB1-PMS deep well increased to values of 800 to $1,000 \mu \mathrm{S} / \mathrm{cm}$ because of large concentrations of dissolved chloride in the groundwater at RB1-PMS deep when water withdrawal was occurring.

Passive recharge with treated surface water and recharge from rainfall resulted in an increase in $\mathrm{DO}$ (fig. $5 D$ ) because the recharge water contained a greater amount of DO. Concentrations of DO in the RB1-P well (shallow and deep monitoring depths) increased from about $4 \mathrm{mg} / \mathrm{L}$ to about 10 to $12 \mathrm{mg} / \mathrm{L}$ during recharge conditions. DO concentrations in the RB1-PMS deep well increased from less than $1 \mathrm{mg} / \mathrm{L}$ before recharge to about $5 \mathrm{mg} / \mathrm{L}$ after rainfall infiltrated into the basin. The RB1-MS shallow and deep wells had small concentrations of DO ( 0.0 to $.3 \mathrm{mg} / \mathrm{L})$ during the study period indicating that the oxygen-rich recharge water did not affect 

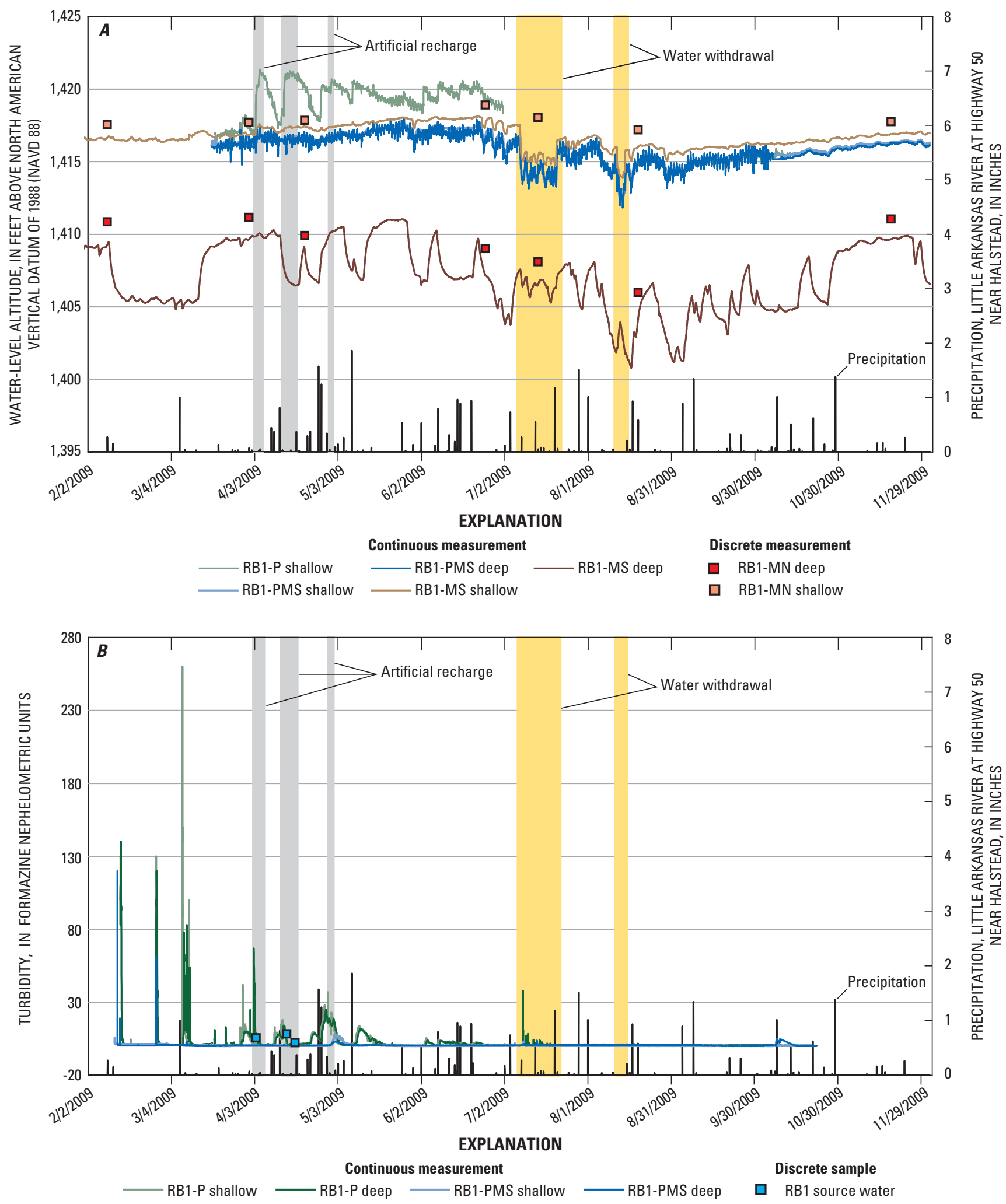

Figure 5. Continuous measurement of: $(A)$ water-level altitude; $(B)$ turbidity; $(C)$ specific conductance; and $(D)$ dissolved oxygen at RB1 monitoring sites. 

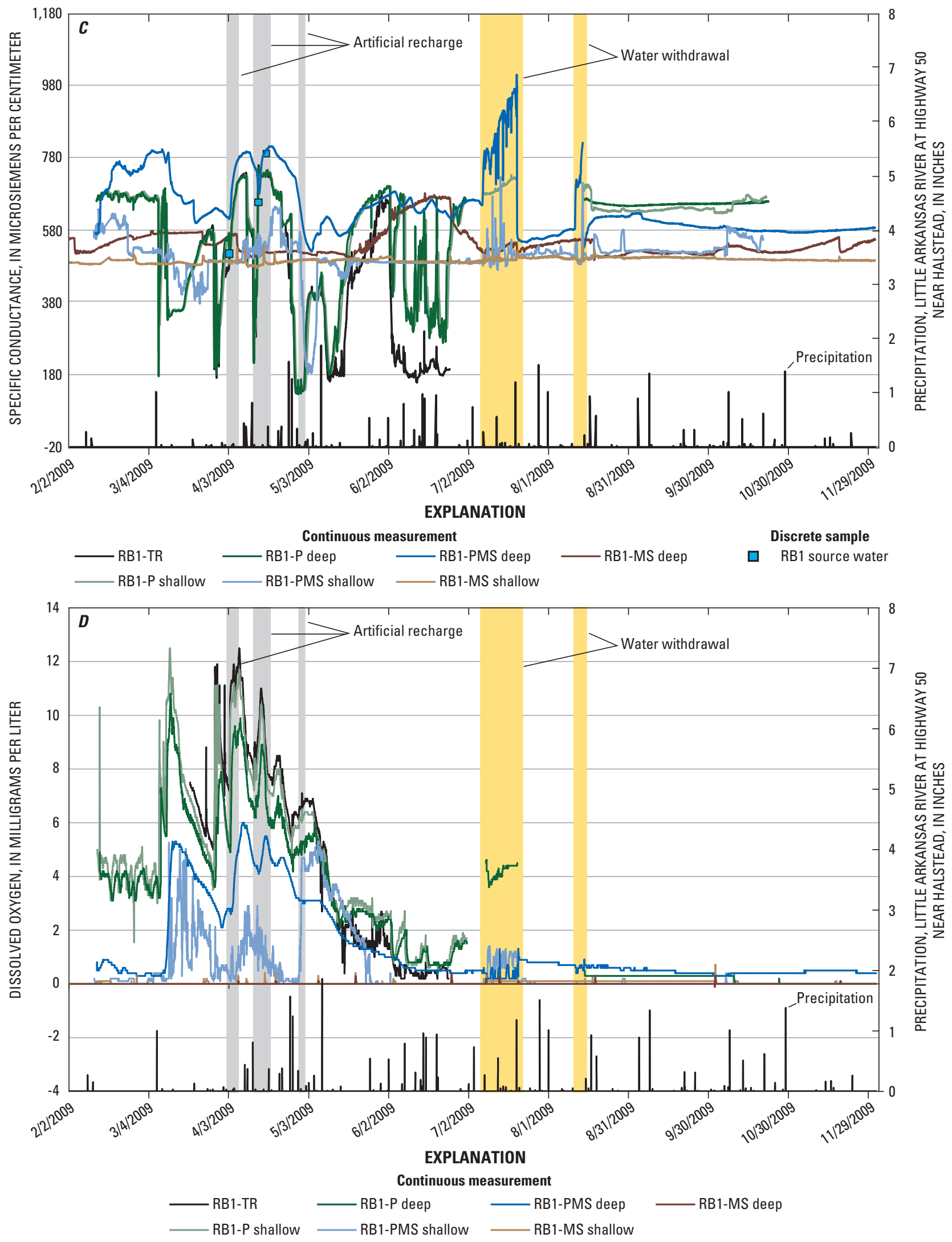

Figure 5. Continuous measurement of: $(A)$ water-level altitude; $(B)$ turbidity; $(C)$ specific conductance; and $(D)$ dissolved oxygen at RB1 monitoring sites.-Continued 


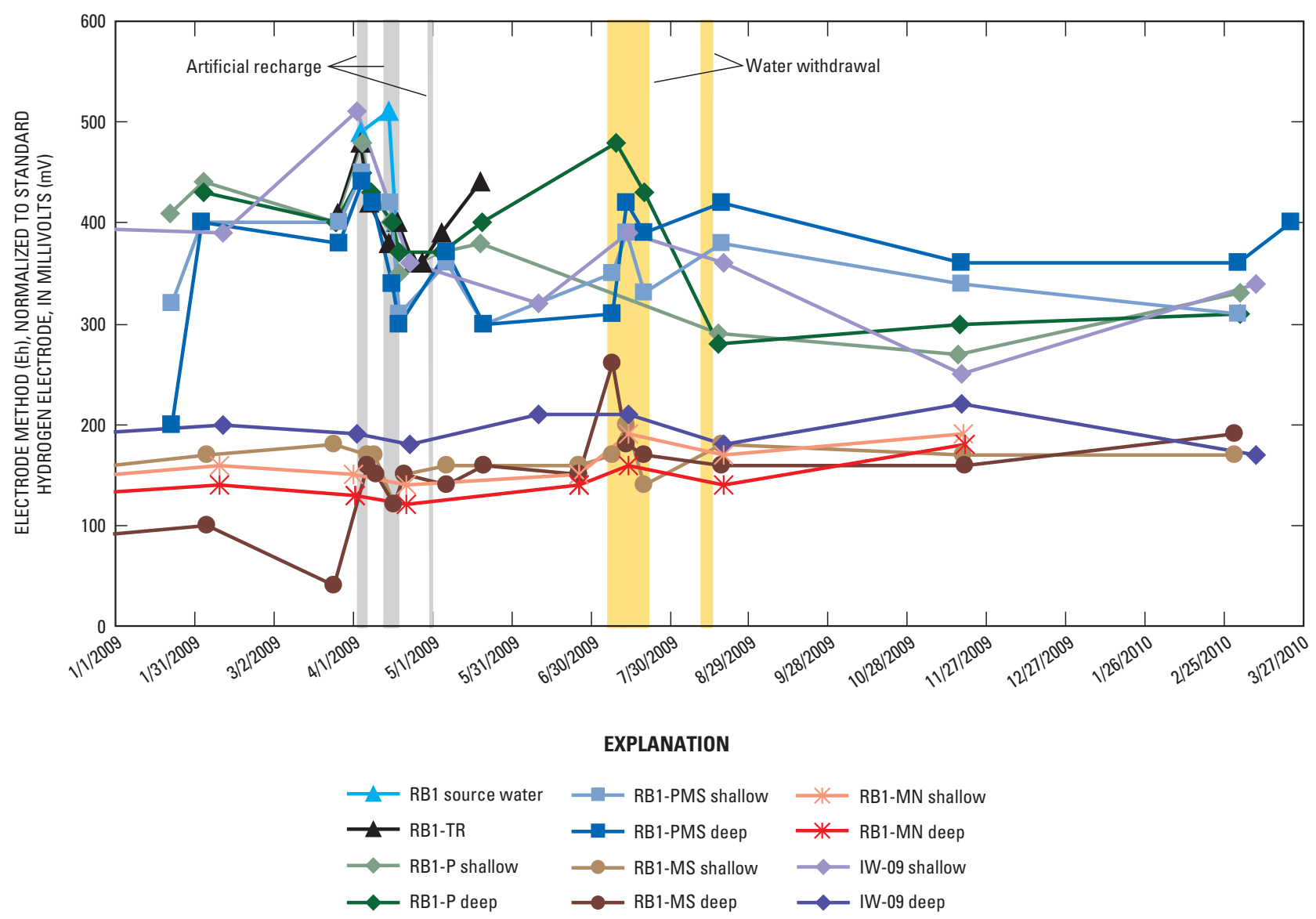

Figure 6. Oxidation-reduction potential from samples collected at RB1 sites during 2009-2010.

the aquifer in the area of the RB1-MS wells. During the period after artificial recharge and before water withdrawal, DO concentrations generally decreased in all wells. Concentrations in the RB1-PMS wells were near $0 \mathrm{mg} / \mathrm{L}$ immediately before water withdrawal and increased slightly to near $1 \mathrm{mg} / \mathrm{L}$ during water withdrawal. The increase in DO concentration in the RB1-PMS wells during water withdrawal is likely caused by previously recharged water (oxygenated surface water) entering the well, or by increased surface infiltration of standing water in the basin because of pumping conditions. After the RB1-P well and trench system was disconnected and after water was withdrawn, DO values in all wells decreased to prerecharge conditions of less than $1 \mathrm{mg} / \mathrm{L}$.

\section{Discrete Samples}

In addition to continuous monitoring, physical properties were measured as discrete samples were collected. Measured properties include groundwater altitude, $\mathrm{SC}, \mathrm{pH}$, water temperature, turbidity, DO, and ORP. Results are shown in table 5 at the back of this report. ORP is discussed below.

ORP is measured in millivolts $(\mathrm{mV})$ relative to the standard hydrogen electrode and indicates the tendency of constituents in water to cause oxidation or reduction reactions
(Hem, 1992). The larger the ORP, the more oxidizing the conditions. For example, ORP values of more than $250 \mathrm{mV}$ indicate that the dominant iron species in groundwater is ferric iron, which can lead to chemical precipitation of ferric iron oxides or hydroxides in aquifer material, which can decrease the effective porosity (Ross-Schmidt and others, 2007). If ORP is less than $250 \mathrm{mV}$, more reducing conditions may result in dissolution of arsenic, iron, and manganese in aquifer materials, thereby leading to larger dissolved concentrations of these constituents in groundwater. Even lower ORP indicates more reducing conditions that involve geochemical and biological processes which convert dissolved sulfate to hydrogen sulfide gas. Different communities of iron-related bacteria and sulfate-reducing bacteria survive and thrive under different ORP conditions (Cullimore, 2007). Iron-related bacteria and sulfate-reducing bacteria in RB1 water are of interest because of the potential to plug or foul wells.

Historic (before 2009) measurements of ORP were consistently less than $250 \mathrm{mV}$ for RB1-MN shallow and deep, RB1-MS shallow and deep and IW-09 deep wells (Ziegler and others, 2010). Historic ORP measurements from IW-09 shallow samples, which had values near or more than $400 \mathrm{mV}$, were substantially larger than those from other area wells. During artificial recharge with treated surface water, ORP in RB1-TR, RB1-P well (shallow and deep sampling depths), 

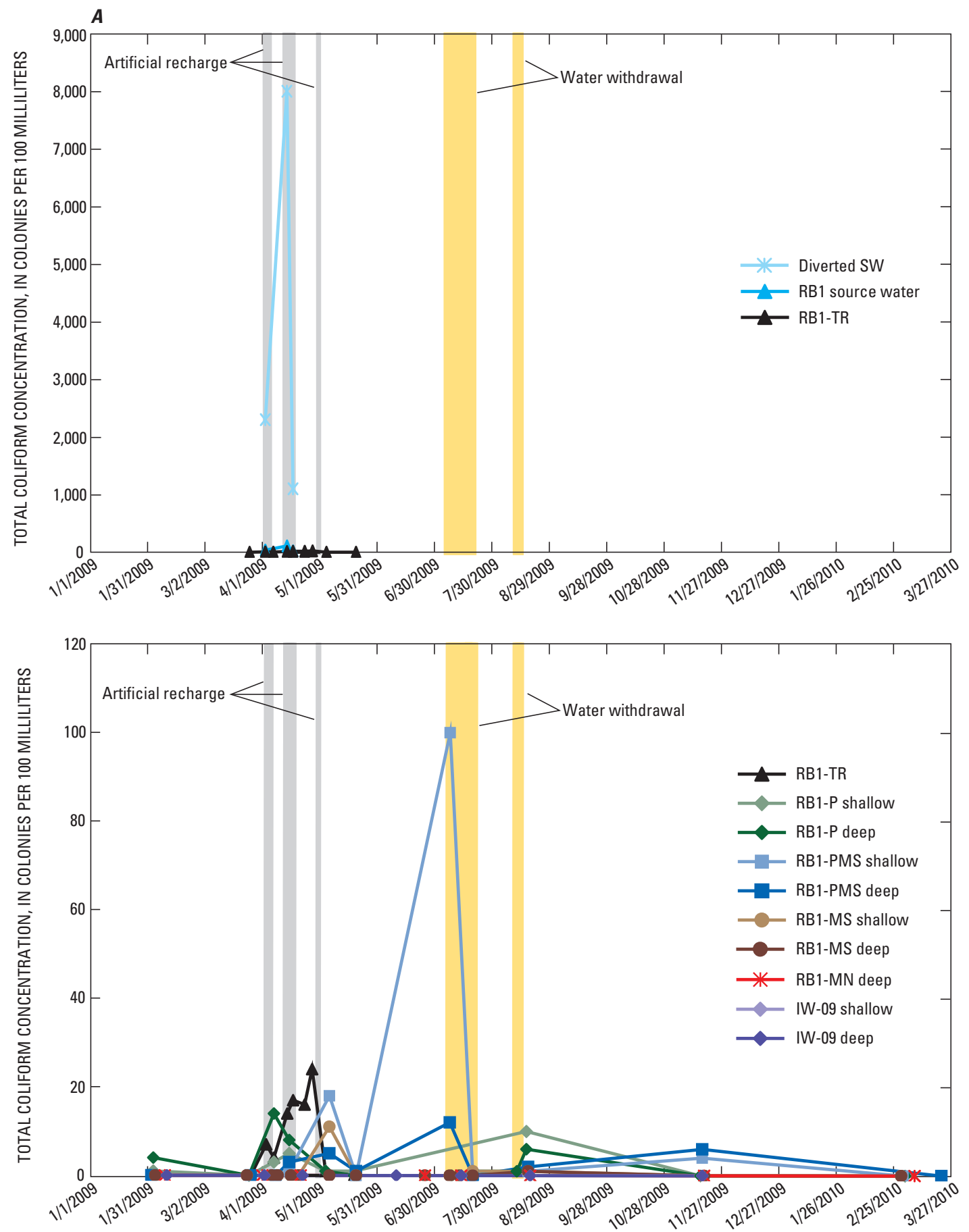

Figure 7. Indicator bacteria densities from selected analytical methods in water samples collected from study area during 2009-2010; (A) Total coliform LES Endo method (membrane Endo agar, Lawrence Experiment Station) ( $B$ ) fecal coliform, M-FC MF (0.7-micron membrane filtration, Fecal Coliform agar) (C) Escherichia coli (modified thermotolerant Escherichia coli membrane filtration method).

and RB1-PMS shallow wells increased and then decreased, following the trend of the ORP value of the RB1 source water (fig. 6). All ORP values measured in samples from RB1-TR, RB1-P well (shallow and deep sampling depths), RB1-PMS shallow well, and IW-09 shallow well were larger than $300 \mathrm{mV}$. ORP values for the RB1-MS shallow and deep wells decreased during recharge and increased during water withdrawal, but values for RB1-MN and IW-09 deep well were relatively unchanged. The changing ORP is indicative of the mixing of oxygenated recharge water with aquifer water, and the travel of water through the system from RB1-TR, to RB1-P well to RB1-PMS wells and RB1-MS wells. After recharge and water withdrawal, ORP returned to values similar to those before recharge (fig. 6). 

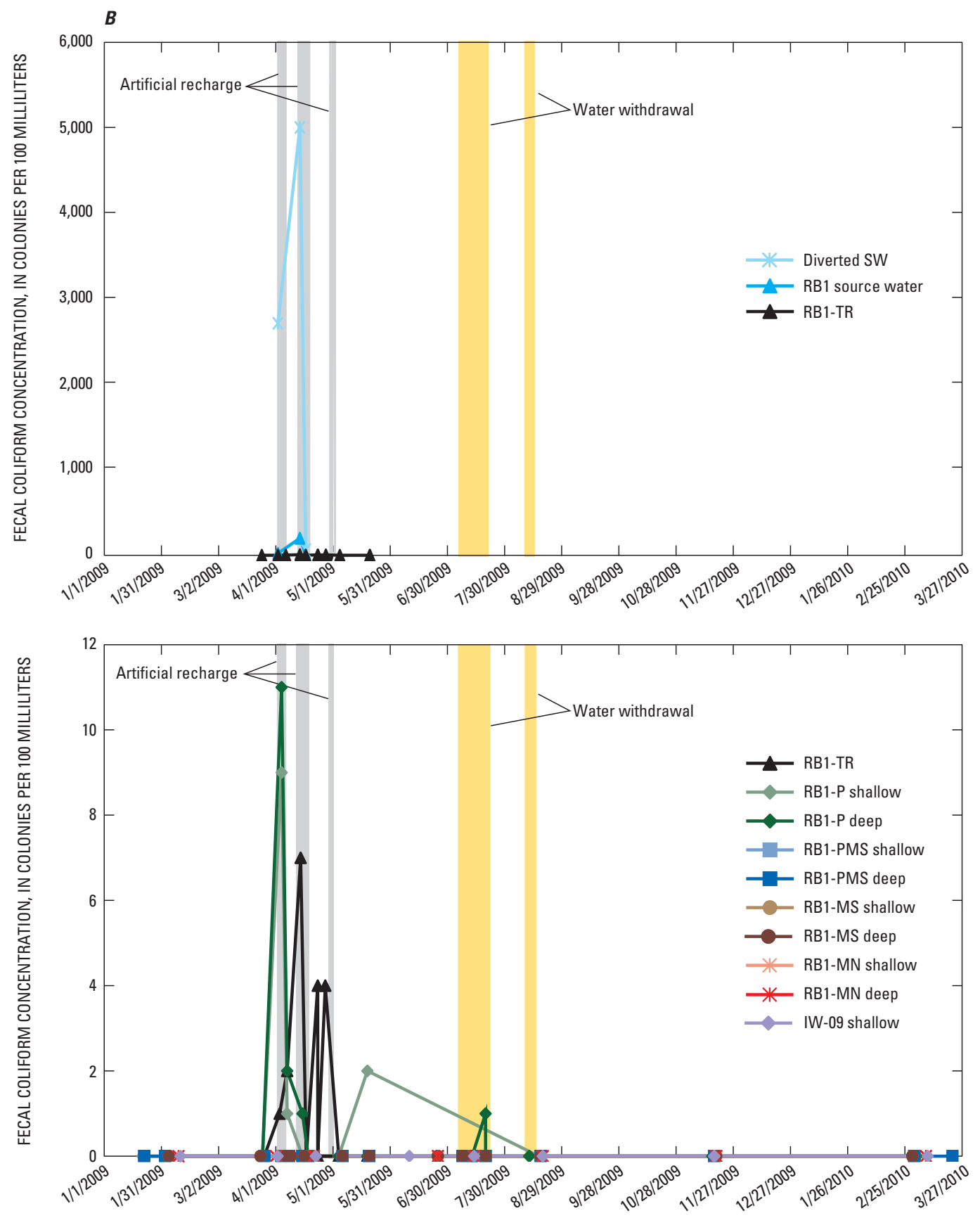

Figure 7. Indicator bacteria densities from selected analytical methods in water samples collected from study area during 2009-2010; (A) Total coliform LES Endo method (membrane Endo agar, Lawrence Experiment Station) (B) fecal coliform , M-FC MF (0.7-micron membrane filtration, Fecal Coliform agar) (C) Escherichia coli (modified thermotolerant Escherichia coli membrane filtration method).-Continued

\section{Bacterial and Viral Indicators}

Water samples were analyzed to determine concentrations of bacterial indicators (total coliform, fecal coliform, $E$. coli), viral indicators (coliphage virus), and a spore-forming bacterial indicator (Clostridium perfringens). The USEPA Maximum Contaminant Level Goal (MCLG) for total coliform (including fecal coliform and E. coli) is $0 \mathrm{CFU} / 100 \mathrm{~mL}$ in compliance with the USEPA National Primary Drinking
Water Regulations for Total Coliforms (U.S. Environmental Protection Agency, 1989). Clostridium perfringens is a sulfite reducing spore-forming bacterium normally present in human and animal feces. Clostridial spores are resistant to heating and survive longer than coliform bacteria and consequently are used as an indicator of past fecal contamination. Coliphage virus is a virus that infects coliform bacteria, and therefore, is an indicator of possible fecal contamination. 

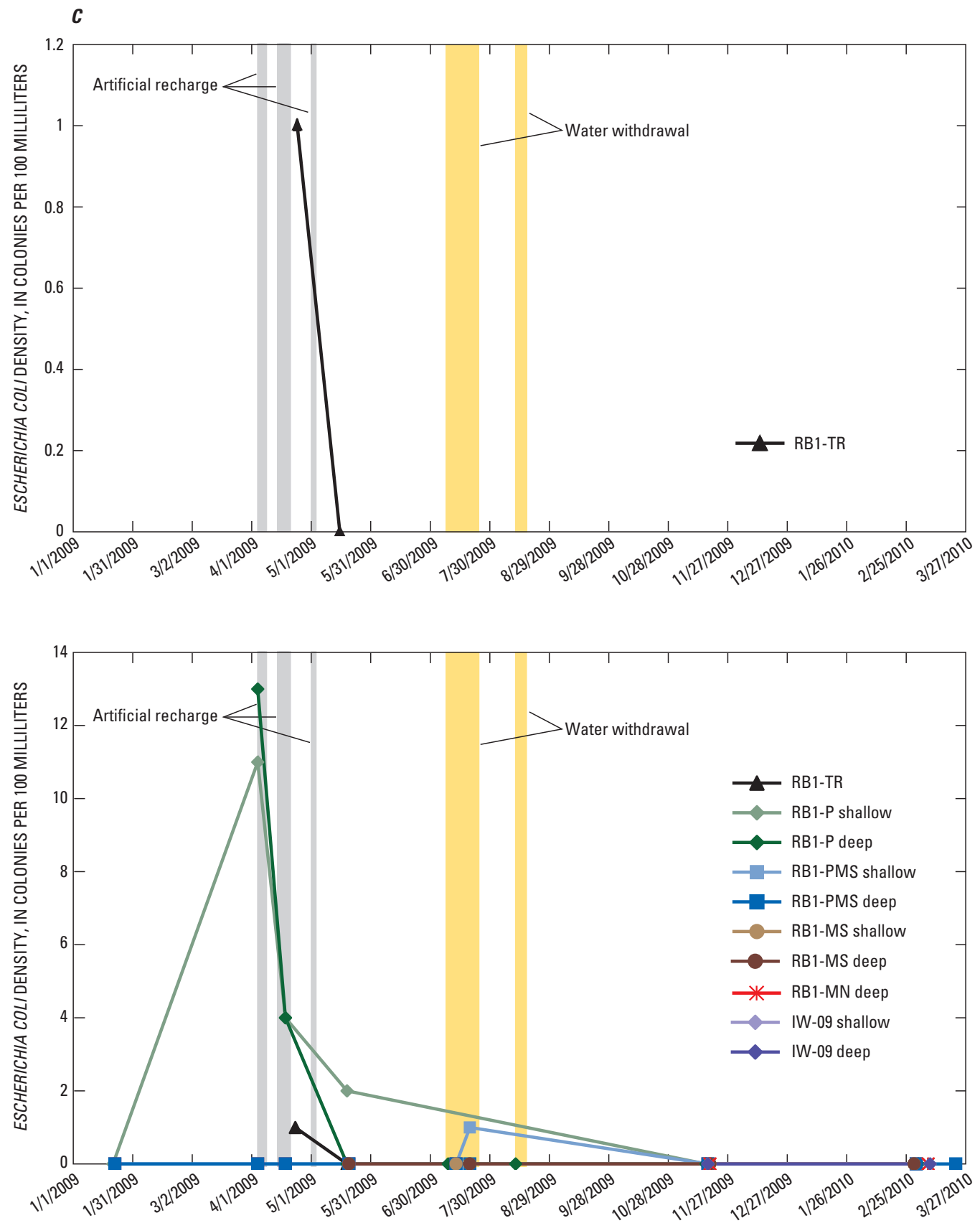

Figure 7. Indicator bacteria densities from selected analytical methods in water samples collected from study area during 2009-2010; $(A)$ Total coliform LES Endo method (membrane Endo agar, Lawrence Experiment Station) ( $B$ ) fecal coliform, M-FC MF (0.7-micron membrane filtration, Fecal Coliform agar) (C) Escherichia coli (modified thermotolerant Escherichia coli membrane filtration method).-Continued

Results from selected test methods are presented in figures 7 and 8 . Data from all test methods are presented in table 6 at the back of this report.

\section{Before Artificial Recharge}

Before the recharge experiment, bacterial indicators had been detected in some water samples from RB1-MS, RB1-MN, and IW-09 wells. With the exception of a sample collected from IW-09 on 3/19/2002, the detections of bacteria were small (6 or fewer CFU/100 ml).

During 2008, before installation of the passive gravity recharge well and trench system, coliform bacteria were detected in one sample from the RB1-MS deep well (1 CFU/100mL). Coliform bacteria were not detected in water samples from RB1-MS shallow, RB1-MN shallow and deep, or IW-09 shallow and deep wells (Ziegler and others, 2010). 

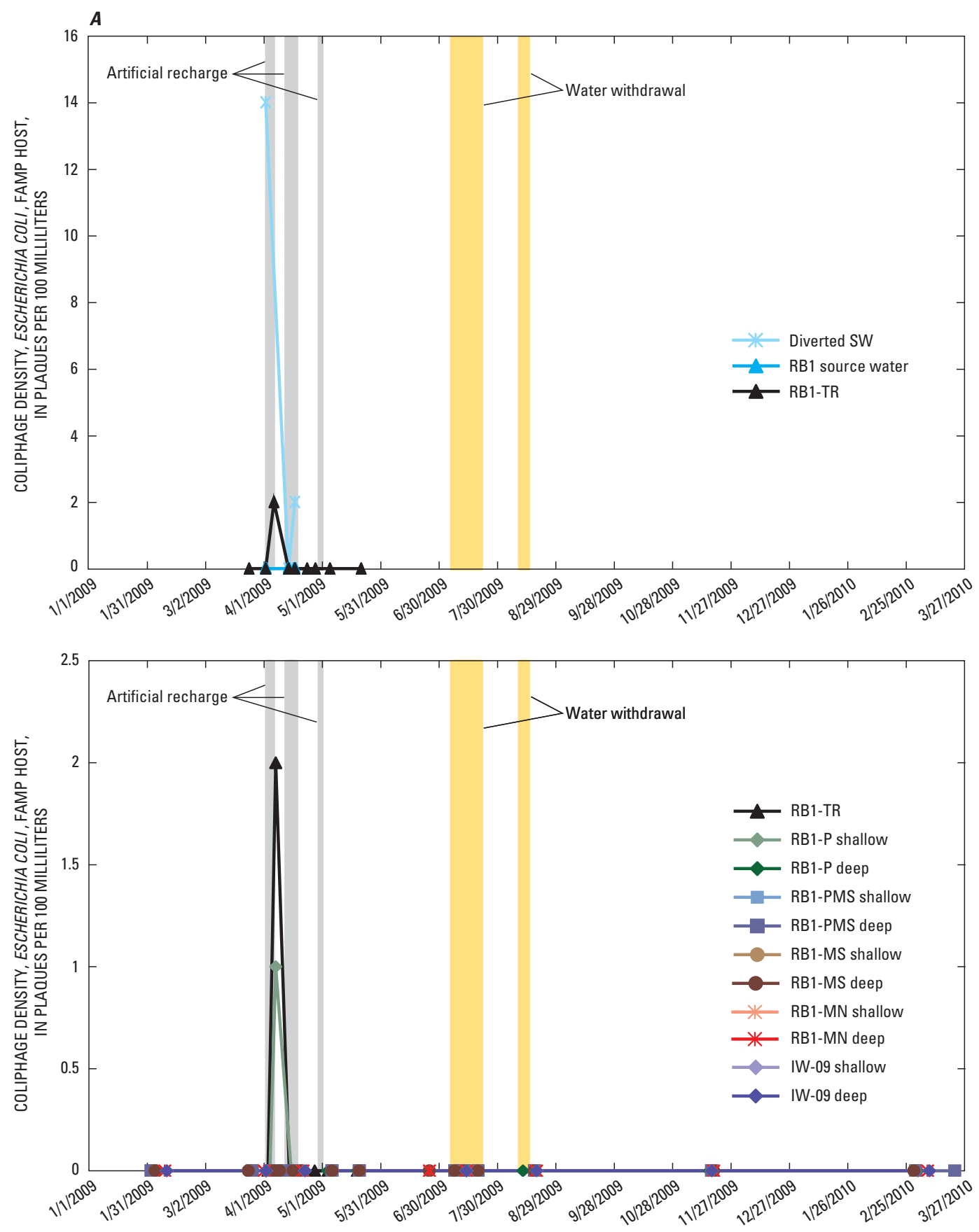

Figure 8. Indicator organism densities in water samples collected from study area during 2009-2010; (A) Coliphage, Esterichia coli, Famp host (single agar layer method) (B) Coliphage, Esterichia coli, C13 host (single agar layer method) (C) Clostridium perfringens (Clostridium perfringens agar membrane filtration method).

During January, February, and March of 2009, after installation of RB1-TR, RB1-P well, and RB1-PMS monitoring sites but before artificial recharge water was pumped into the trench, total coliform, fecal coliform, or E. coli bacteria were detected in about 28 percent of samples (12 of 43) from RB1-TR, RB1-P well (shallow and deep sampling depths), and RB1-PMS shallow and deep wells. Counts ranged from 1 to $59 \mathrm{CFU} / 100 \mathrm{~mL}$. The count of $59 \mathrm{CFU} / 100 \mathrm{~mL}$ was measured in the RB1-P well (shallow sampling depth) immediately after well installation. About 9 percent of samples ( 3 of 32) from the RB1-MS, RB1-MN and IW-09 wells had detectable total coliform, fecal coliform, or $E$. coli bacteria.

Neither Clostridium perfringens bacteria nor coliphage virus were detected in water from any wells. Infiltration of rainfall was the only source of water to the trench and passive recharge system during this time, indicating the likely source of the bacteria was the trench fill material. 

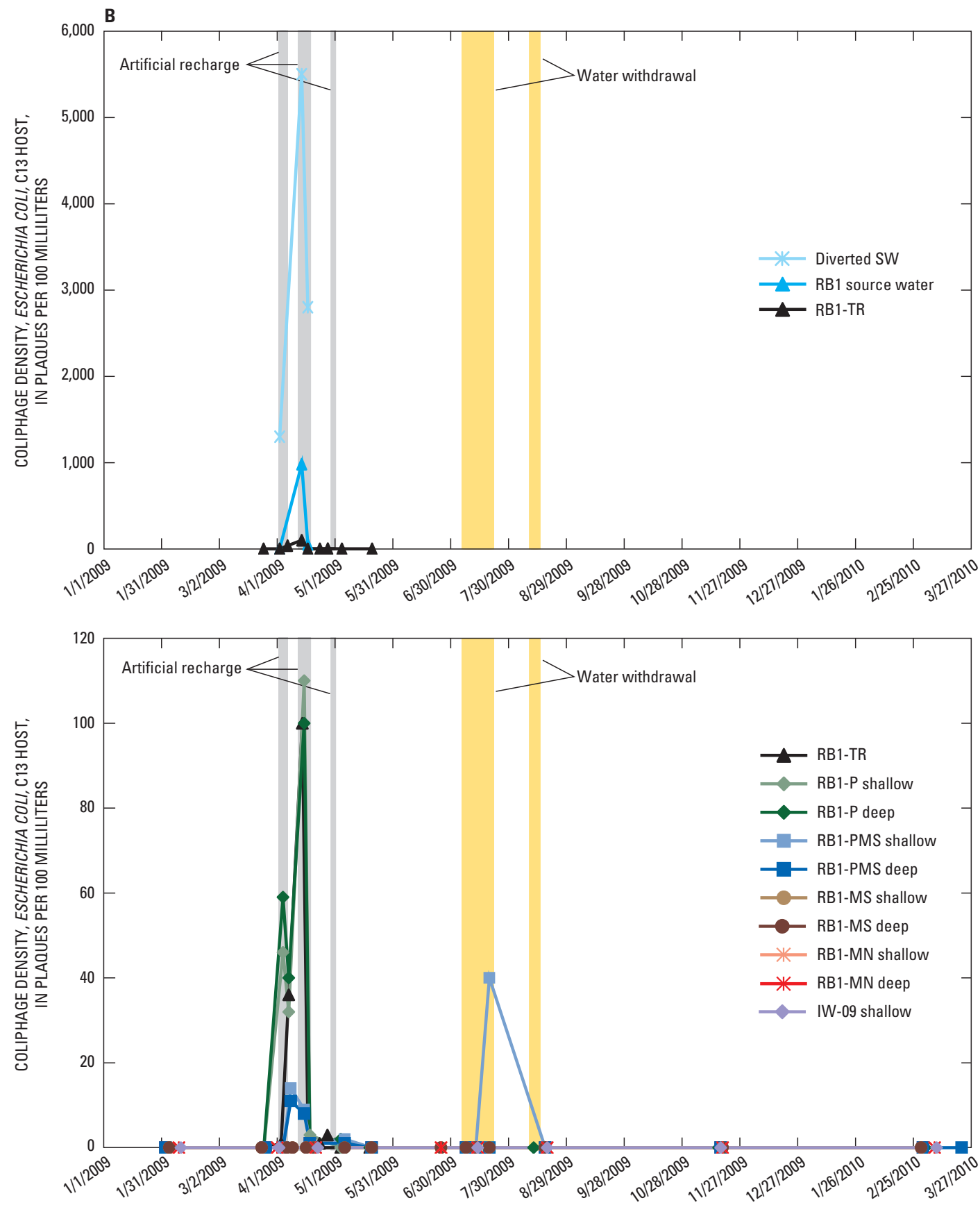

Figure 8. Indicator organism densities in water samples collected from study area during 2009-2010; (A) Coliphage, Esterichia coli, Famp host (single agar layer method) (B) Coliphage, Esterichia coli, C13 host (single agar layer method) (C) Clostridium perfringens (Clostridium perfringens agar membrane filtration method).-Continued

\section{During Artificial Recharge}

The City of Wichita reported that a total of 576,308 gal of treated surface water was used to test the passive well and trench system at RB1: 244,312 gal were recharged April 3-5, 2009; 291,578 gal April 13-17, 2009; and 40,418 gal on April 30, 2009. During the recharge period, water samples collected of RB1 source water had total coliform counts ranging from 37 to $108 \mathrm{CFU} / 100 \mathrm{~mL}$, and fecal coliform counts ranging from 22 to $196 \mathrm{CFU} / 100 \mathrm{~mL}$.

Analysis of water samples collected from RB1-TR, RB1-P well (shallow and deep sampling depths), and RB1PMS wells during April of 2009 had total coliform bacteria counts ranging from 7 to $>120 \mathrm{CFU} / 100 \mathrm{~mL}$ of sample.

Most of these samples also had detectable fecal coliform $(<1$ to $11 \mathrm{CFU} / 100 \mathrm{~mL})$ and $E$. coli $(<1$ to $13 \mathrm{CFU} / 100 \mathrm{~mL})$. 

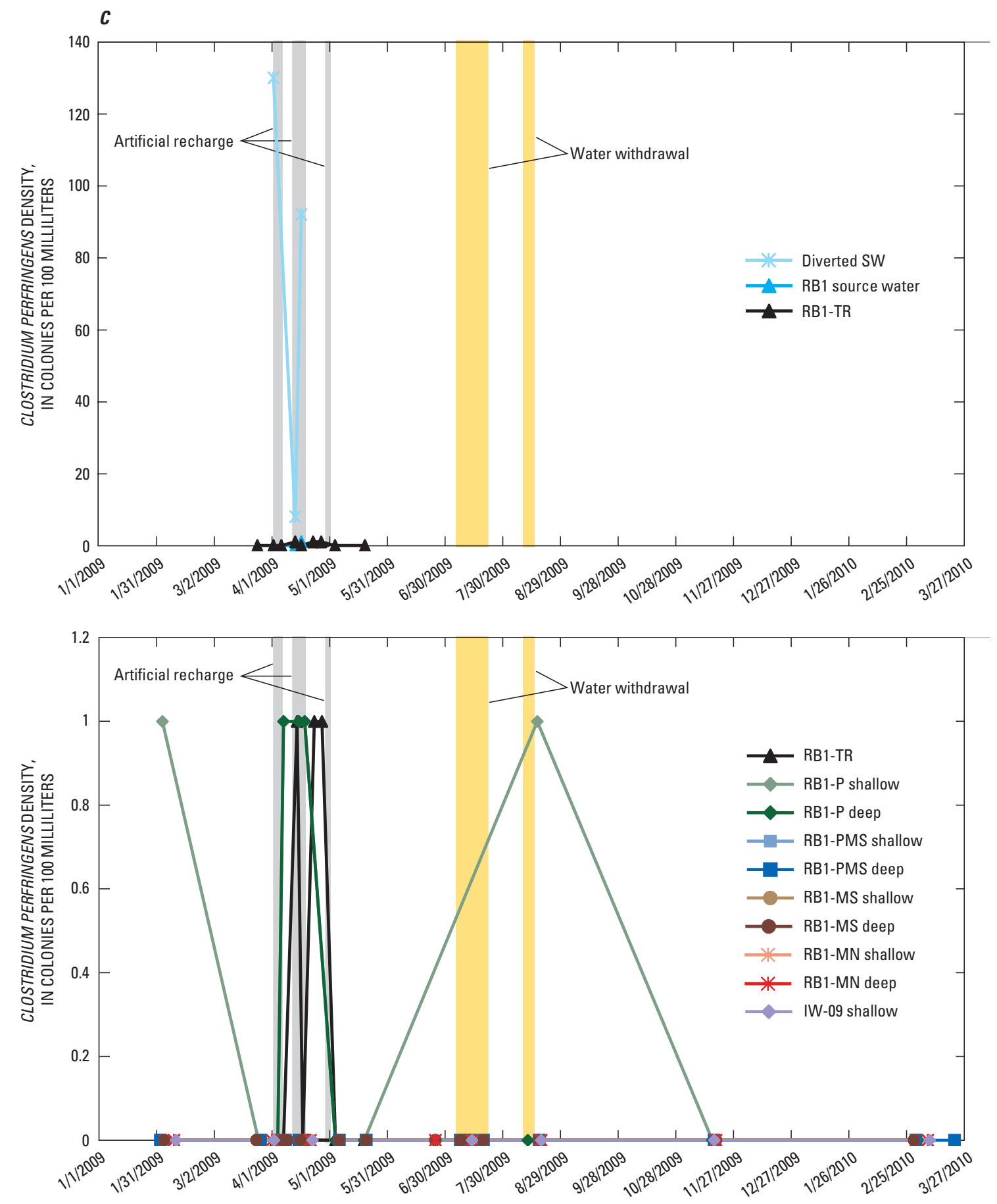

Figure 8. Indicator organism densities in water samples collected from study area during 2009-2010; (A) Coliphage, Esterichia coli, Famp host (single agar layer method) (B) Coliphage, Esterichia coli, C13 host (single agar layer method) (C) Clostridium perfringens (Clostridium perfringens agar membrane filtration method).-Continued

Coliphage virus was present in all samples (1 to $100 \mathrm{CFU} /$ $100 \mathrm{~mL}$ ) from RB1-TR, RB1-P well (shallow and deep sampling depth), and RB1-PMS wells collected during April 2009. Water samples from the RB1-MS wells, the RB1-MN wells, and the IW-09 wells had no detectable indicator bacteria or coliphage virus during April 2009.

\section{After Artificial Recharge and Before Water Withdrawal}

Water samples collected from RB1-TR, RB1-P well (shallow and deep sampling depths), and RB1-PMS wells during May and June of 2009 had total coliform bacteria counts ranging from $<1$ to $50 \mathrm{CFU} / 100 \mathrm{~mL}$ of sample. One sample 
also had detectable fecal coliform and E. coli. Coliphage virus was detected in three samples (one from RB1-P deep, one from RB1-PMS shallow, and one from RB1-PMS deep) collected in early May 2009. Coliform bacteria was detected in two samples collected from the RB1-MS shallow well during May 2009, but fecal coliform, E. coli, and coliphage virus were not detected. No detections of viruses or bacteria were measured in the RB1-MS deep well, the RB1-MN wells, or the IW-09 well during May and June, 2009.

\section{During Water Withdrawal}

The trench system was disconnected from the RB1-P well on July 8, 2009, and the passive well recharge system was no longer functional after this date. Approximately 1,500,000 gallons of water were pumped out of the Equus Beds aquifer at RB1 through the RB1-P well July 7-21, 2009, and 325,000 gallons were removed August 11-14, 2009. Samples were collected of water removed from the aquifer (labeled RB1-P deep well on figures 5, 6, 7, 8, 9, 10, 11, 12, 13, 14, and 15 during this time period) and from all RB1 monitoring wells. Water samples collected from the RB1-P well (labeled deep sampling depth) between July 1 and August 14 had total coliform detections ranging from $<1$ to $17 \mathrm{CFU} /$ $100 \mathrm{~mL}$ and from $<1$ to $5 \mathrm{MPN}$ (most probable number)/ $100 \mathrm{~mL}$ of sample, and there was a detection of fecal coliform (1 CFU/100 mL) in the sample collected on July 20, 2009.

Total coliform bacteria were detected in water samples collected from RB1-PMS shallow well ( $<1$ to $2,000 \mathrm{CFU} /$ $100 \mathrm{~mL}$ and $>200$ to $>2,400 \mathrm{MPN} / 100 \mathrm{~mL}$ ) and RB1-PMS deep well (43 to $690 \mathrm{MPN} / 100 \mathrm{~mL}$ and $<1$ to $37 \mathrm{CFU} /$ $100 \mathrm{~mL}$ ) on July 8,13 , and 20, 2009. Fecal coliform bacteria were detected in the sample collected from the RB1-PMS shallow well on July 13, 2009 (3 CFU/100 mL), and coliphage virus (40 PFU/100mL (plaque-forming units per 100 milliliters)) and E. coli (1 CFU/100 mL) were detected in the July 20 sample.

Coliform bacteria were detected in the water samples collected from the RB1-MS shallow well ( $<1$ to $32 \mathrm{MPN}$ / $100 \mathrm{~mL}$ and $<1$ to $17 \mathrm{CFU} / 100 \mathrm{~mL})$ and RB1-MS deep well (15 to $>200 \mathrm{MPN} / 100 \mathrm{~mL}$ and $<1$ to $8 \mathrm{CFU} / 100 \mathrm{~mL}$ ) on July 13 and 20, 2009. Coliphage virus was not detected in samples from the RB1-MS, RB1-MN, or IW-09 wells. No virus or bacteria were detected in samples collected from RB1-MN or IW-09 wells during water withdrawal.

\section{After Water Withdrawal}

Pumping from the RB1-P well was discontinued on August 14. Coliform bacteria was detected in water samples collected from the P-well (shallow and deep sampling depths), RB1-PMS wells, and RB1-MS wells about 3 days after pumping was discontinued ( 1 to $20 \mathrm{CFU} / 100 \mathrm{~mL}$ and 1 to $200 \mathrm{MPN} / 100 \mathrm{~mL})$. Clostridium perfringens was detected in the RB1-P well (shallow sampling depth) (1 CFU/100 ml).
There were no detections of coliphage virus, fecal coliform, or E. coli in late August samples. A sample set was collected November 16-18, 2009, about 3 months after pumping was discontinued. Total coliform bacteria ranging from 1 to $20 \mathrm{CFU} / 100 \mathrm{ml}$ and 1 to $100 \mathrm{MPN} / 100 \mathrm{ml}$ were measured in samples from the RB1-P well (shallow sampling depth), the RB1-PMS shallow and deep wells, and the RB1-MS deep well. Fecal coliform was detected in the IW-09 shallow and deep wells (1 to $2 \mathrm{CFU} / 100 \mathrm{ml}$ ) and in the RB1-PMS deep well (1 CFU/100 ml). Clostridium perfringens, coliphage virus, and $E$. coli were not detected in any samples collected November 16-19, 2009. Total coliform was detected $(120 \mathrm{CFU} / 100 \mathrm{ml})$ in water from the RB1-PMS deep well in samples collected March 2, 2010, but a sample collected on March 22, 2010, had no detections. Coliphage and Clostridium perfringens were not detected in either sample collected from the RB1-PMS deep well during March 2010. No detections of bacterial or viral indicators were made in samples collected from RB1-P well (shallow and deep sampling depths), RB1PMS shallow well, RB1-MS shallow and deep wells, RB1MN shallow and deep wells, and IW-09 shallow and deep wells during on March 2010.

\section{Biological Activity Reaction Tests (BART)}

Iron-related and sulfate-reducing bacteria are a natural part of the environment and may enter an aquifer through wells or other interaction with the surface. When these bacteria enter an environment with conditions suitable to growth they multiply. The many types of iron-related bacteria use iron in their metabolism and grow best in water with large iron content. They tend to colonize on well and pump surfaces and can cause slime and unpleasant odors and tastes. They may deposit iron oxide on surfaces or produce corrosive acids. Many types can substitute nitrates for oxygen during metabolism, and therefore, can grow in aerobic or anaerobic environments. Enteric bacteria are bacteria that normally or pathogenically live in the intestines of animals. Some types of iron-related bacteria are also enteric bacteria. Sulfate-reducing bacteria reduce sulfates, usually in anaerobic and reducing conditions, to obtain energy. A by-product of their metabolism is corrosive hydrogen sulfide (Cullimore, 2007).

This report describes the results of the IRB-BART with respect to iron-related enteric bacteria and potential ironrelated well-fouling bacteria and SRB-BART for potential well-fouling sulfate-reducing bacteria. Results of BART are shown in table 7 at the back of this report.

Enteric bacteria were detected by IRB-BART in about 12 percent ( 3 of 26 ) of water samples collected before artificial recharge (fig. 9A). During artificial recharge, the percentage of samples with detections of enteric bacteria increased to 43 percent (17 of 40), and decreased to about 21 percent (4 of 19) after artificial recharge was discontinued but before water was withdrawn from the aquifer at RB1. IRB-BART were positive for enteric bacteria in about 53 percent 

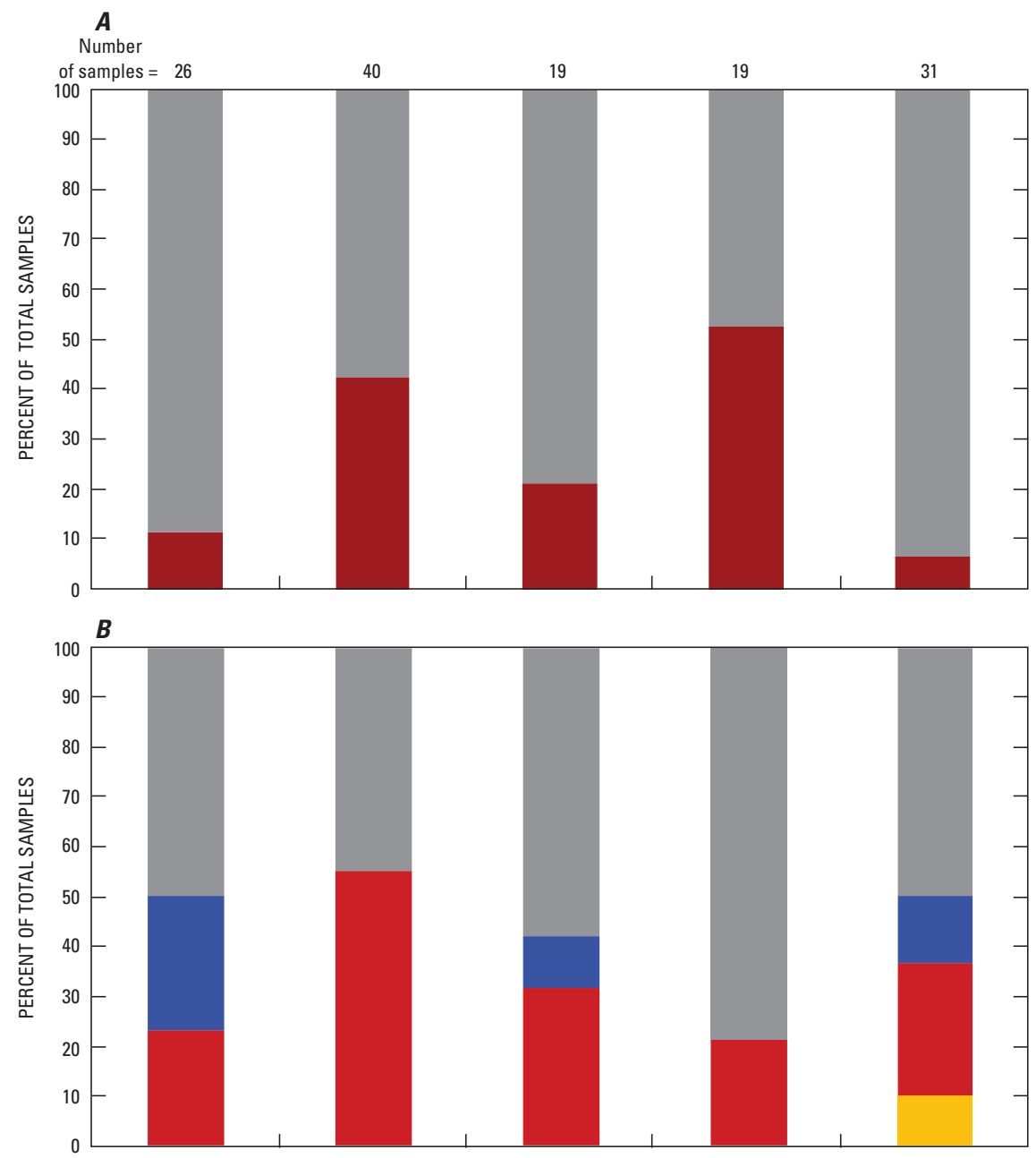

\section{EXPLANATION}

No detection

- Moderately aggressive

aggressive

Very aggressive

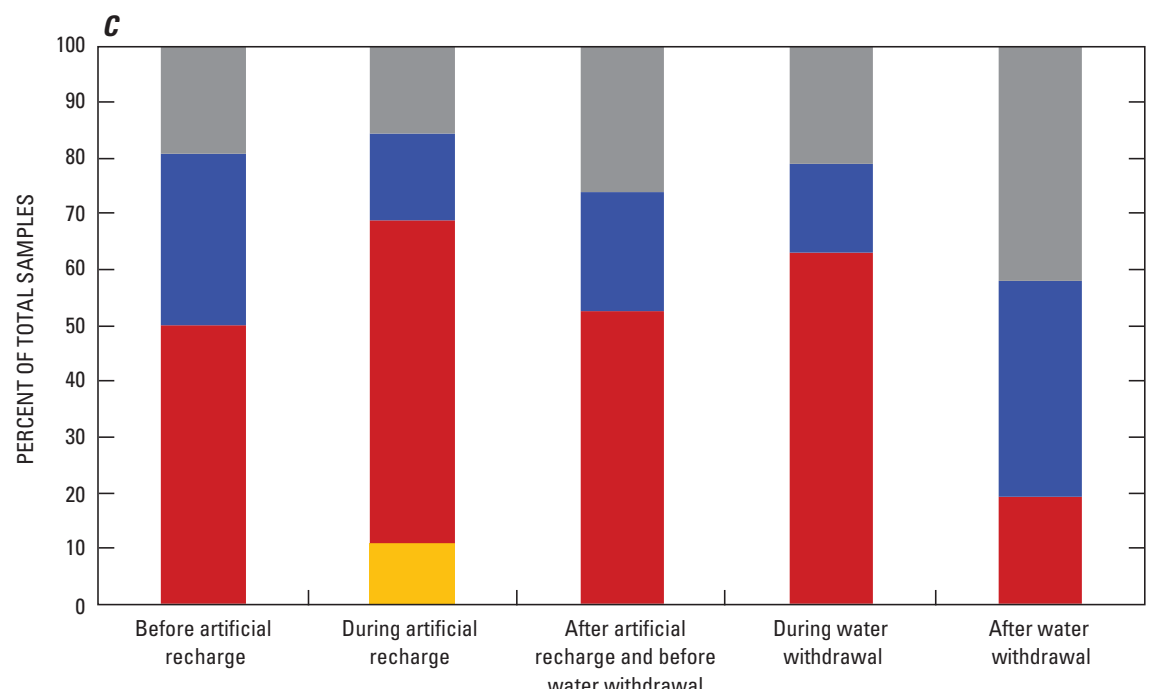

EXPLANATION

No detection

- Moderately aggressive

aggressive

Very aggressive

Figure 9. (A) IRB BART, Percentage of samples with detections of enteric bacteria; (B) IRB BART, Detections of potential well-fouling iron-related bacteria; $(C)$ SRB BART, Detections of sulfate-reducing bacteria.

(10 of 19) of samples collected from the RB1 sites during water withdrawal from the aquifer. These detections were in samples collected from the RB1-P well (shallow and deep sampling depths), the RB1-PMS shallow and deep wells, and RB1-MS deep wells. About 6 percent (2 of 31) of IRB-BART samples collected after water withdrawal had detections of enteric bacteria, less than the percentage of detections before artificial recharge.

IRB-BART results can also indicate the presence of slime- or corrosion-producing iron-related bacteria. When a 
positive reaction for these iron-related bacteria occurred, the number of days from sample collection to the first reaction was recorded. If a positive reaction occurred within 2 days, the IRB bacteria were considered very aggressive; 3 or 4 days, aggressive; 5 to 8 days, moderately aggressive. Potentially well-fouling IRB were detected in 47 percent of IRB-BART samples (fig. 9B). Most of these populations were moderately aggressive to aggressive, although very aggressive populations were present in samples collected from the RB1-P well (shallow and deep sampling depths) and RB1-MS shallow well immediately after water withdrawal. In general, wells with smaller average numbers of IRB were those located upgradient or laterally removed from artificial recharge activities (IW-09 and RB1-MN wells) suggesting that the passive well artificial recharge activities increased the IRB populations in the aquifer, possibly because of additional nutrients and oxygen-rich water.

Sulfate-reducing bacteria were detected in most (78 percent) of the RB1 water samples tested with SRBBART. Very aggressive populations (1 day to reaction) were found in water samples collected during artificial recharge. Aggressive populations (2 to 4 days to reaction) were found in all periods and were present in about one-half of all water samples tested. Although SRB grow in anaerobic environments, populations were smaller in water samples from wells located upgradient or laterally removed from the passive gravity recharge well artificial recharge (IW-09 and RB1-MN wells) and the oxygenated water.

\section{Select Major Ions, Trace Elements, and Organic Compounds}

Environmental changes that may occur as a result of artificial recharge activities are evaluated through analysis of major ions, trace metals, and organic compounds. Results of laboratory analysis for major ions (chloride), trace elements (arsenic and iron), and organic compounds (atrazine) in water samples collected as part of this evaluation are presented in tables 8 and 9 at the back of this report. Piper diagrams on figure 10 show the relative concentrations and changes in major ions that occur in the RB1 area during the evaluation of the passive gravity recharge well system. The water chemistry of the RB1-MN shallow and deep, and RB1-MS shallow and deep wells remained relatively constant through all periods (before artificial recharge, during artificial recharge, after artificial recharge and before water withdrawal, during water withdrawal, and after water withdrawal). The geochemistry of the water sampled from RB1-TR, RB1-P well (shallow and deep sampling depths), and RB1-PMS wells indicated evidence of having been affected by the recharge water after artificial recharge began with a greater percent concentration of chloride, sodium, and sulfate, and relatively lesser amounts of calcium and bicarbonate. After recharge ceased, but before water was withdrawn from the aquifer, concentrations returned to values similar to those before recharge. The group of points visible on figure $10 C$ that retain a greater proportion of sulfate represent samples collected 4 days after recharge was discontinued. When water was being withdrawn from the aquifer, concentrations of chloride increased in the withdrawn water (labeled RB1-P deep well on figures 5, 6, 7, 8, 9, 10, 11, 12, 13,14 , and 15 during this time period) and in the RB1-PMS shallow and deep wells. Although the Piper diagrams of the water samples collected from the RB1-P well (shallow and deep sampling depths), and the RB1-PMS shallow and deep wells are similar to the RB1-MN shallow well, the concentration of iron samples is dissimilar. This trend is discussed further in the "Chloride" and "Effects of Experimental Passive Artificial Recharge: Synthesis" sections of the report. In addition, during water withdrawal the water chemistry in the withdrawn water (RB1-P deep sampling depth) and RB1-PMS wells was similar. This trend may be the result of water "recycling": water removed from the aquifer through the RB1-P well was placed in a basin adjacent to the trench and passive well, and then was drawn back into the aquifer because of pumping and later removed again.

After water withdrawal, concentrations of the major ions in the RB1 wells returned to values similar to those before artificial recharge through the passive well began. Before water withdrawal the trench was disconnected from the RB1-P well, and RB1-TR was not sampled.

\section{Chloride}

The USEPA recommends a maximum concentration of $250 \mathrm{mg} / \mathrm{L}$ for chloride ions to avoid undesirable taste (U.S. Environmental Protection Agency, 1986). In addition to a salty taste in drinking water, large concentrations of chloride (>350 mg/L) make water unusable for irrigation purposes (Bauder and others, 2007).

The primary sources of chloride to the Equus Beds aquifer are underlying rocks of the Wellington Formation, the Arkansas River, municipal wastewater treatment, and waste associated with previous oil and natural gas extraction near Burrton (Ziegler and others, 1999; Whittemore, 2007). The chloride plume near Burrton (fig. 1) has migrated downgradient about 3 miles in 40 to 45 years, but the migration has slowed since 1992 because of a decrease in hydraulic gradient caused by decreased pumping of wells downgradient from the plume. Geographic placement of the first phase of full-scale recharge facilities should further decrease the gradient and slow saltwater migration from the Burrton plume (Ziegler and others, 2010).

Chloride concentrations in samples collected from RB1 sites during 2009 were all less than $250 \mathrm{mg} / \mathrm{L}$ (fig. 11). The RB1-MN shallow well (60 ft depth) consistently had the greatest chloride concentration with values ranging from 150 to $170 \mathrm{mg} / \mathrm{L}$. This well is located in the northwest part of the RB1 study area (fig. 2) and is the closest to the Burrton brine plume, geographically. Ziegler and others (2010) report that the Burrton chloride plume has reached the RB1 area in the shallow aquifer before the deep aquifer. The larger 

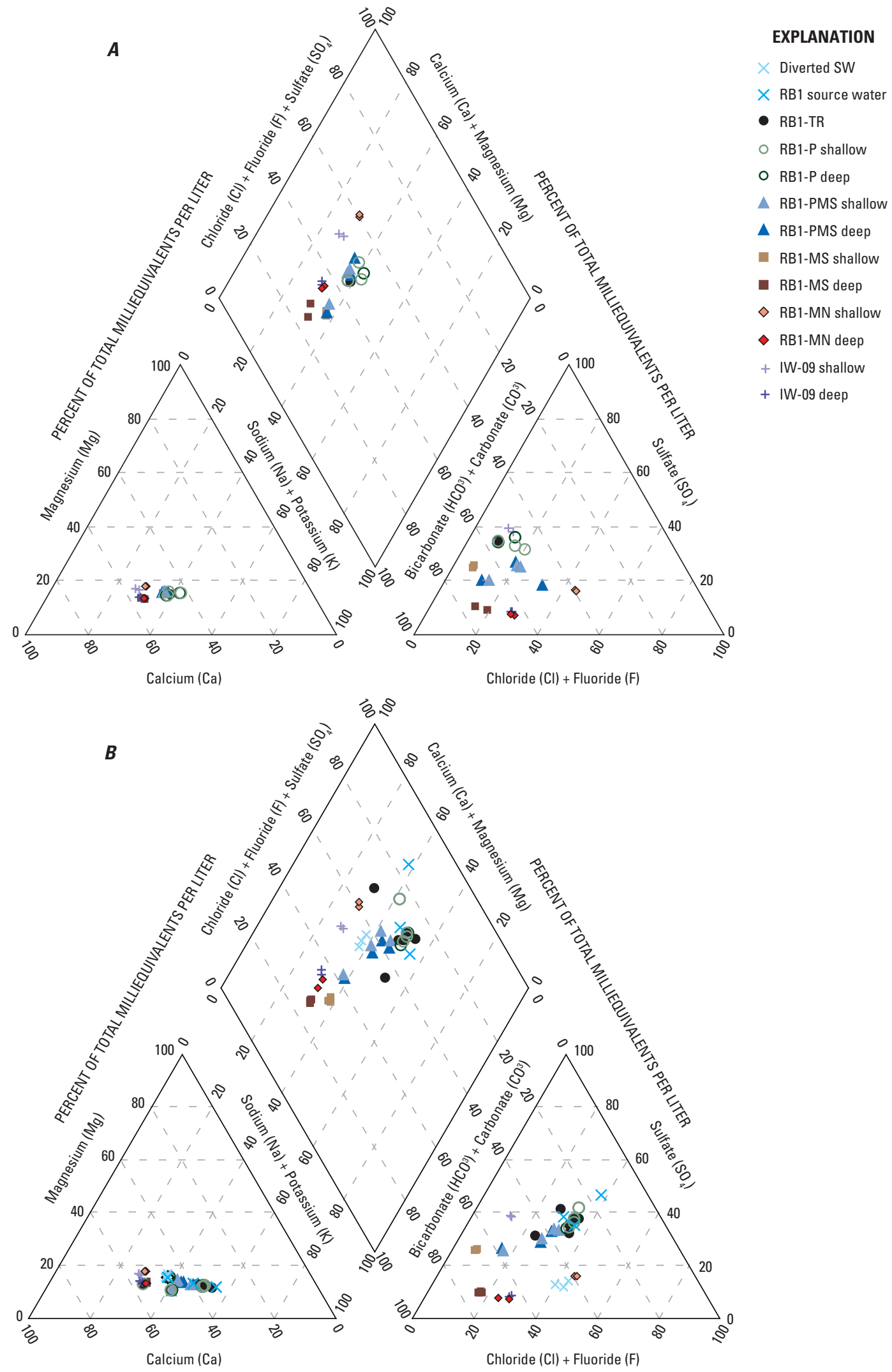

Figure 10. Major ion chemistry of water samples from RB1 area wells $(A)$ before artificial recharge $(B)$ during artificial recharge $(C)$ after artificial recharge and before water withdrawal $(D)$ during water withdrawal $(E)$ after water withdrawal. 


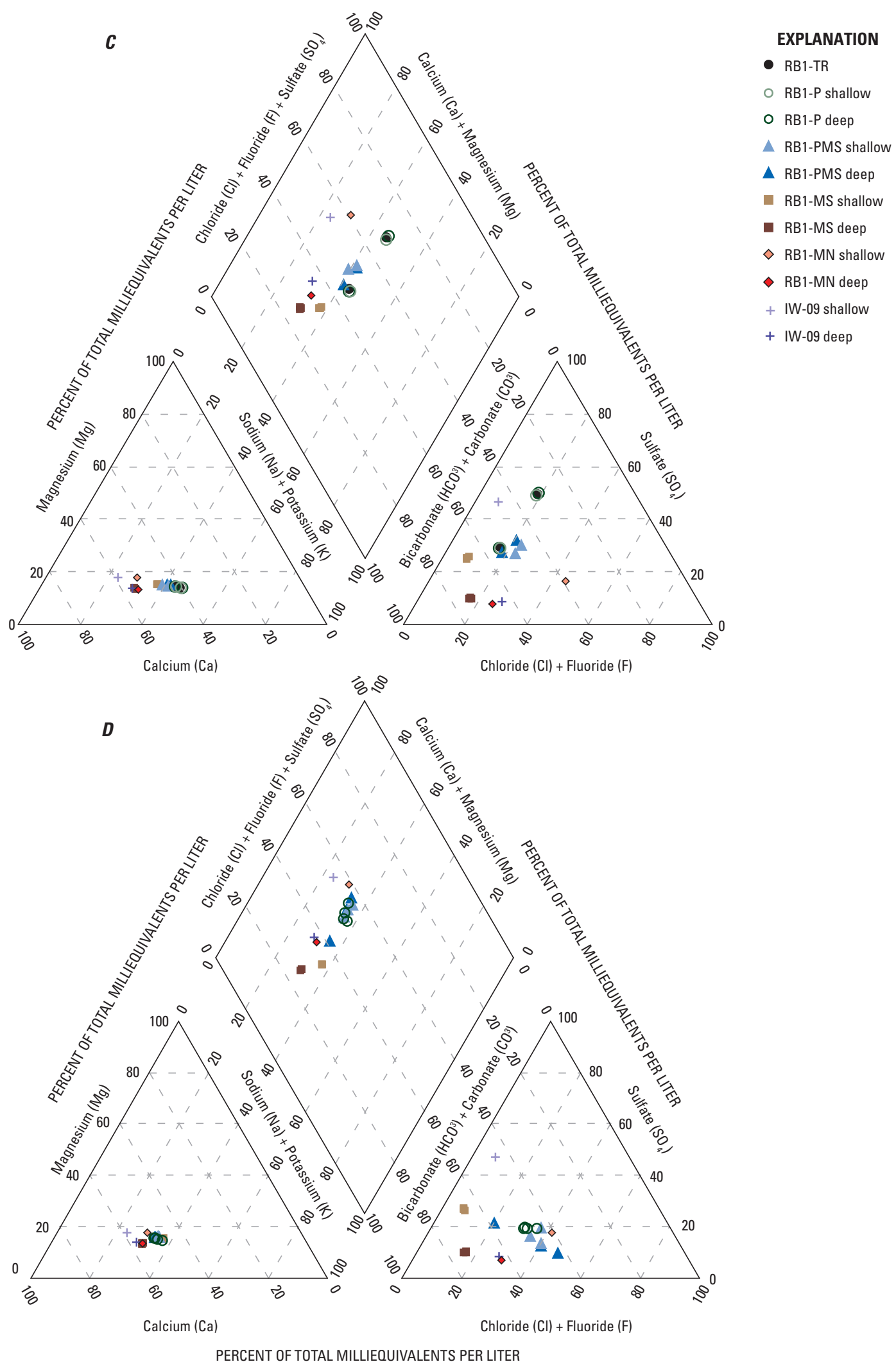

Figure 10. Major ion chemistry of water samples from RB1 area wells $(A)$ before artificial recharge $(B)$ during artificial recharge $(C)$ after artificial recharge and before water withdrawal $(D)$ during water withdrawal $(E)$ after water withdrawal.-Continued 


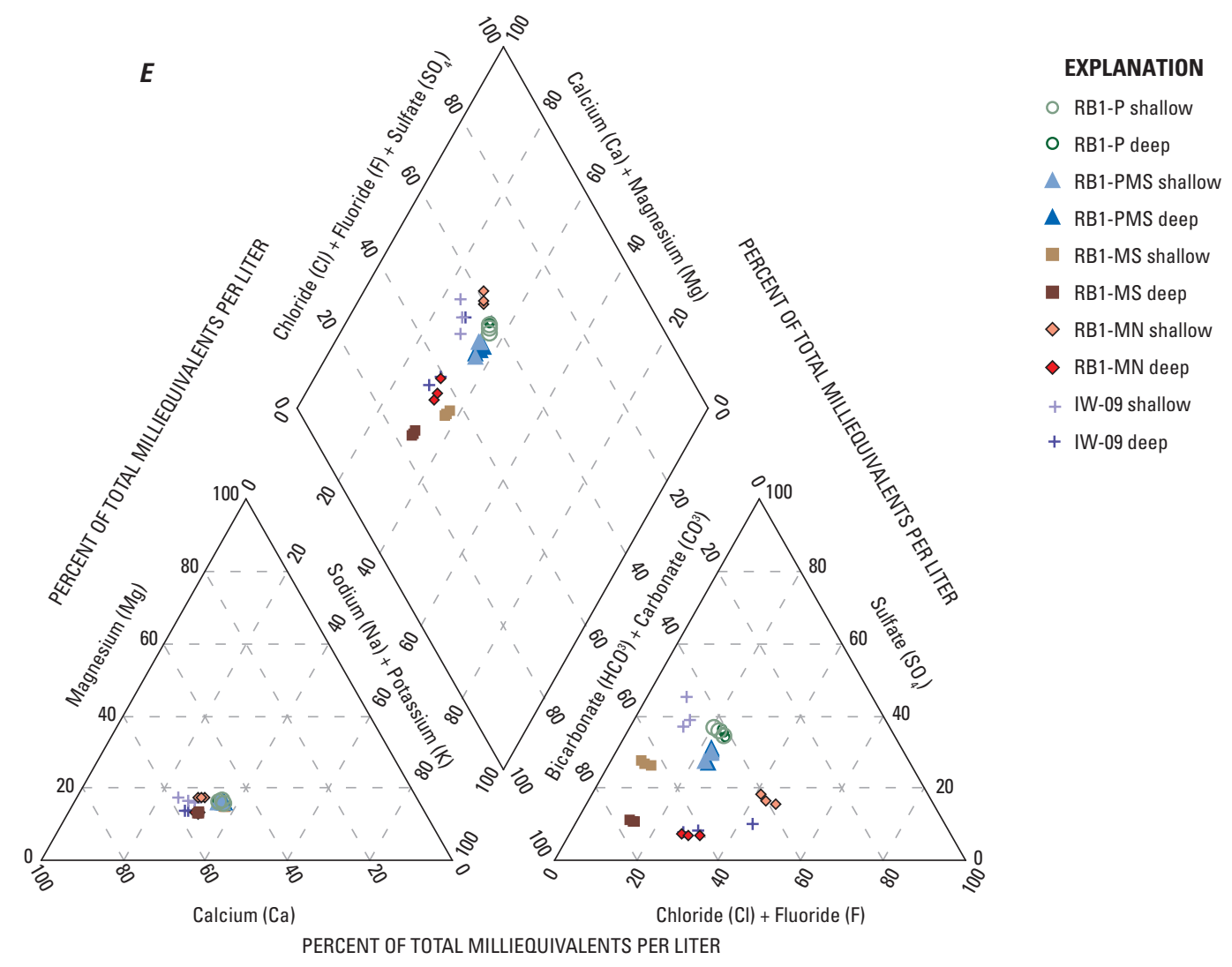

Figure 10. Major ion chemistry of water samples from RB1 area wells $(A)$ before artificial recharge $(B)$ during artificial recharge $(C)$ after artificial recharge and before water withdrawal $(D)$ during water withdrawal $(E)$ after water withdrawal._-Continued

concentration of chloride in the shallow zone of some parts of the aquifer may be because of the hydraulic gradient or discontinuous clay layers that locally limit the downward migration of saltwater (Ziegler and others, 2010).

Baseline water samples collected from IW-09 shallow and deep wells, RB1-MN shallow and deep wells, and RB1MS shallow and deep wells, before artificial recharge had chloride concentrations ranging from 12 to $160 \mathrm{mg} / \mathrm{L}$ (table 8 , at the back of this report). The concentration of $160 \mathrm{mg} / \mathrm{L}$ was measured in the RB1-MN shallow well; all other concentration values were $75 \mathrm{mg} / \mathrm{L}$ or less. Chloride concentrations in the Little Arkansas River, calculated from specific conductance values, changed rapidly when precipitation occurred. During the period of artificial recharge, chloride concentrations of 8.5 to $202.0 \mathrm{mg} / \mathrm{L}$ were calculated from measurements of SC in the river. Average concentrations for the three recharge periods, as calculated from SC, were $92.6,93.5$, and $33.1 \mathrm{mg} / \mathrm{L}$ respectively. Chloride concentrations in RB1 source water were $62-94 \mathrm{mg} / \mathrm{L}$. When this water entered the RB1 passive recharge system during artificial recharge, chloride concentrations increased from an average of $34 \mathrm{mg} / \mathrm{L}$ to an average of $64 \mathrm{mg} / \mathrm{L}$ in RB1-TR, RB1-P well (shallow and deep sampling depths). Concentrations in other RB1 wells did not change substantially. During May and June 2009, after artificial recharge and before water withdrawal, concentrations of chloride in water samples returned to pre-recharge levels.

During water withdrawal, chloride concentrations in the RB1-PMS wells increased to values larger than those in RB1 source water. A mass-balance calculation was performed to ascertain whether this large chloride concentration could be because of artificial recharge. The overall equation used to evaluate the balance of chloride into or out of the aquifer at $\mathrm{RB} 1$ is:

$$
C l_{w}=\mathrm{Cl}_{b g}+\mathrm{Cl}_{r}+\mathrm{Cl}_{o}
$$

where:

$$
\begin{aligned}
& \mathrm{Cl}_{w} \quad \text { is the quantity of dissolved chloride } \\
& \text { withdrawn from the aquifer (grams); } \\
& \mathrm{Cl}_{b g} \quad \text { is the background quantity of dissolved } \\
& \text { chloride present in the groundwater before } \\
& \text { artificial recharge (grams); } \\
& \mathrm{Cl}_{r} \quad \text { is the quantity of chloride in water artificially } \\
& \text { recharged (grams); and } \\
& \mathrm{Cl}_{o} \quad \text { is the quantity of dissolved chloride from } \\
& \text { other source (grams). }
\end{aligned}
$$

Values of SC in the Little Arkansas River were used to calculate chloride concentrations in the treated water used 


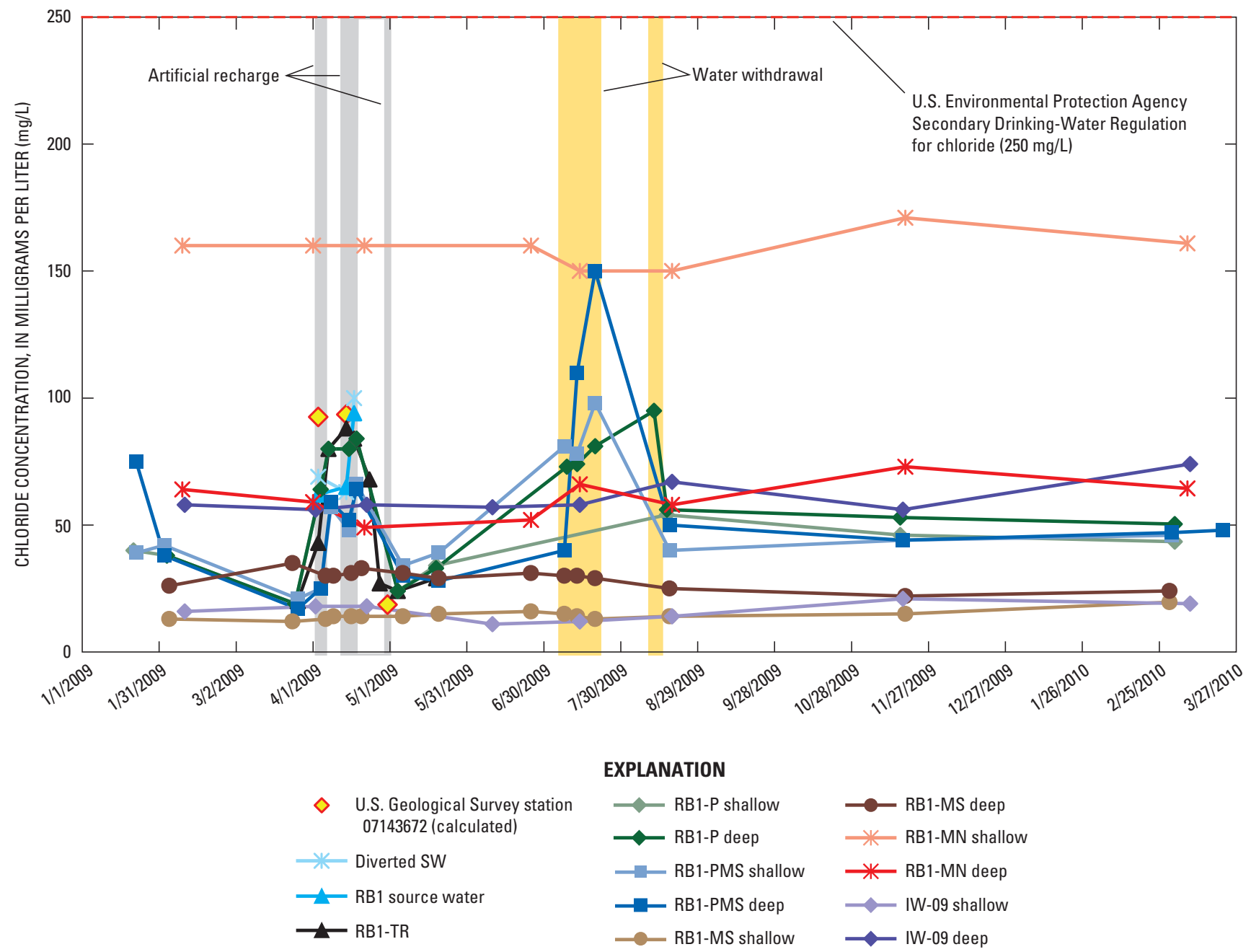

Figure 11. Measured chloride concentrations in water samples collected from RB1 monitoring sites, January 2009 through March 2010.

for recharge. The approximate mass of chloride in the water pumped out of the aquifer in July and August $\left(\mathrm{Cl}_{w}\right)$ was 524,400 grams (g) (computed from the quantity of water pumped out and laboratory measurements of chloride concentration in samples collected of the withdrawn water). The approximate mass of chloride added to the aquifer in the artificial recharge water $\left(\mathrm{Cl}_{r}\right)$ was 191,700 $\mathrm{g}$ (calculated from the quantity of water recharged and the average chloride concentration in the Little Arkansas River during times of recharge). The average background concentration of chloride in groundwater at RB1 $\left(\mathrm{Cl}_{b q}\right)$, estimated from values measured in water samples collected from the RB1-MS shallow and deep wells before artificial recharge began, is $31 \mathrm{mg} / \mathrm{L}$, and the estimated background mass of chloride in the water pumped from the aquifer is $216,000 \mathrm{~g}$. The difference between the total mass pumped from the aquifer and the background mass of chloride is $308,400 \mathrm{~g}$. The difference between the mass of chloride added, and the mass pumped out (greater than the background mass) is $116,700 \mathrm{~g}(308,400-191,700)$. In other words, $116,700 \mathrm{~g}$ (257 pounds (lb)) more chloride was pumped from the aquifer than can be accounted for by artificial recharge water and the background concentration. This indicates that an additional source of water with large chloride concentration relative to that at the RB1-MS wells exists in the aquifer at the RB1 site.

When water was being pumped out of the aquifer through the RB1-P well, chloride concentrations in the RB1-P well (measured in the water withdrawn), and in the RB1-PMS shallow and deep wells increased. One sample from the RB1-PMS deep well had a concentration of $150 \mathrm{mg} / \mathrm{L}$, substantially more than the chloride concentration in the recharge water and the average computed chloride values in the Little Arkansas River, and similar to the concentration in the RB1-MN shallow. This large chloride concentration and the mass balance exercise indicate that as water was being pumped out of the RB1-P well, water with a large chloride concentration from elsewhere in the aquifer was flowing toward the RB1-P and RB1-PMS wells. Although chloride concentrations were similar in samples collected from the RB1-PMS deep well and RB1-MN shallow well during water withdrawal in July $(150 \mathrm{mg} / \mathrm{L}$ and 


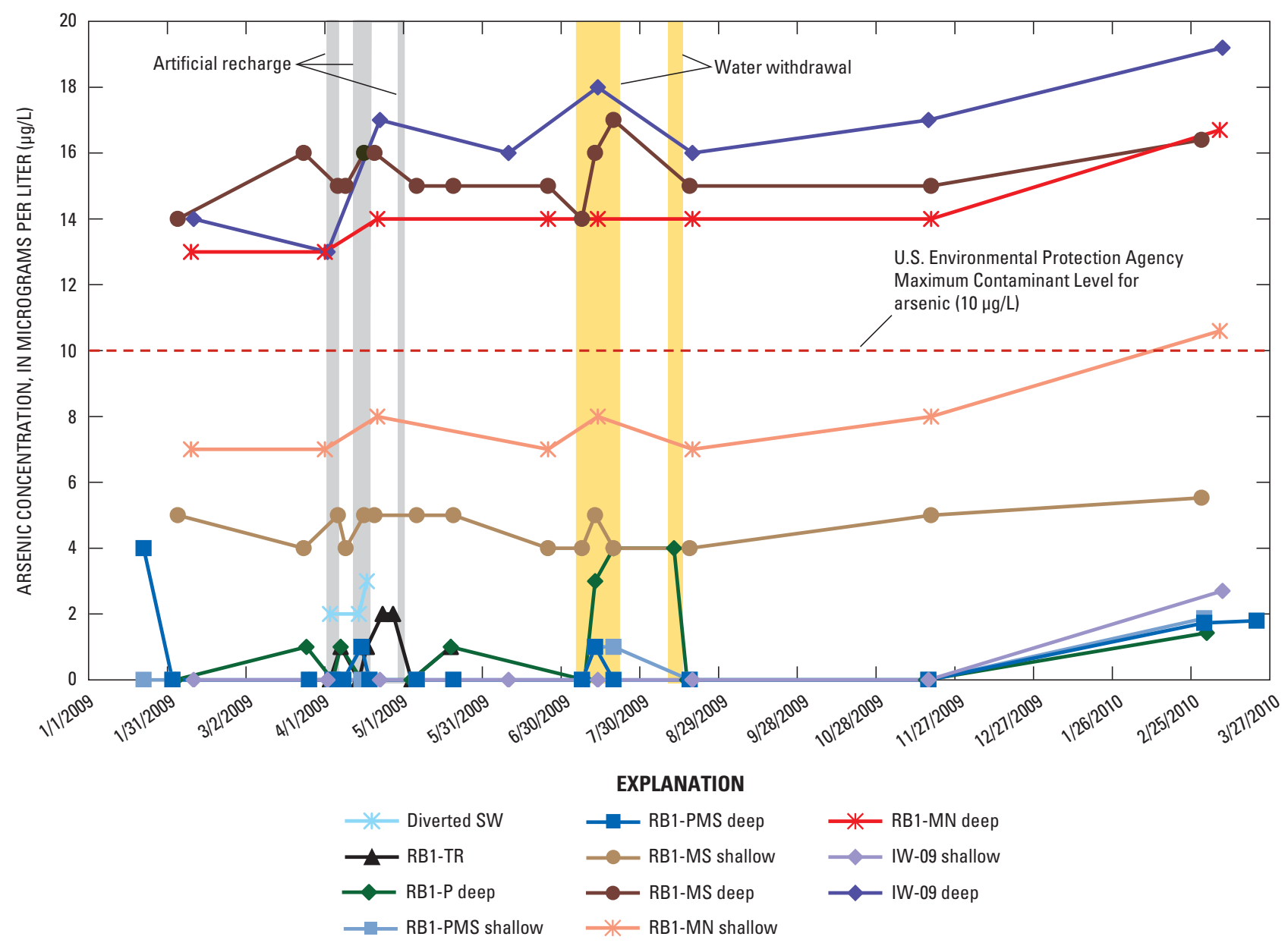

Figure 12. Measured arsenic concentrations in water samples collected from RB1 monitoring sites, January 2009 through March 2010.

$160 \mathrm{mg} / \mathrm{L}$, respectively), iron concentrations were not similar ( $<100$ micrograms per liter $(\mu \mathrm{g} / \mathrm{L})$ and $4,370 \mu \mathrm{g} / \mathrm{L}$, respectively). Samples collected from the RB1-PMS deep well were all undersaturated with respect to iron hydroxide, indicating that precipitation of iron hydroxide had not recently occurred, and suggesting that the water sample from the RB1-PMS deep well with the unusually large chloride value was not from the RB1-MN shallow area. Current data indicates that short-term chloride concentrations in groundwater in the RB1 area have not been affected by passive-recharge activities.

\section{Arsenic}

Arsenic is an undesirable constituent in drinking water because it is toxic to humans in small amounts. Exposure to arsenic has been linked to an increased risk of cancer, circulatory problems, and skin damage (U.S. Environmental Protection Agency, 2005). In 2006, the USEPA reduced the Federal MCL for arsenic from 50 to $10 \mu \mathrm{g} / \mathrm{L}$. Arsenic occurs as a natural part of the environment and is thought to occur naturally in clay layers in the Equus Beds aquifer (Schmidt and others, 2007). The mobility and dissolution of arsenic in a groundwater environment is largely dependent on $\mathrm{pH}$, redox reactions, and competing ions in the environment (Hem, 1992). Artificial recharge activities can alter these properties and increase or decrease the concentration of arsenic in the groundwater through dissolution, precipitation, adsorption, or desorption of arsenic compounds.

Concentrations of arsenic in the Diverted SW samples collected during April 2009 were 2 to $3 \mu \mathrm{g} / \mathrm{L}$ (fig. 12). Arsenic concentrations from RB1 source water samples were less than the reporting level of $1 \mu \mathrm{g} / \mathrm{L}$. Concentrations of arsenic in samples collected from the deeper part of the aquifer at RB1 (IW-09 deep, RB1-MS deep, and RB1-MN deep) were above the MCL and ranged from 13 to $18 \mu \mathrm{g} / \mathrm{L}$. Concentrations do not change substantially with time and do not appear to have been affected by artificial recharge activities. Concentrations of arsenic in all wells were less than the MCL of $10 \mu \mathrm{g} / \mathrm{L}$ and ranged from $<1 \mu \mathrm{g} / \mathrm{L}$ to $8 \mu \mathrm{g} / \mathrm{L}$. The concentration of arsenic in the RB1-P well (deep sampling depth) increased when water was being pumped from the aquifer, yet saturation indices indicate that the water is undersaturated with respect to the arsenic-containing mineral scorodite (details in the "Geochemical Simulations" section), indicating that water from 


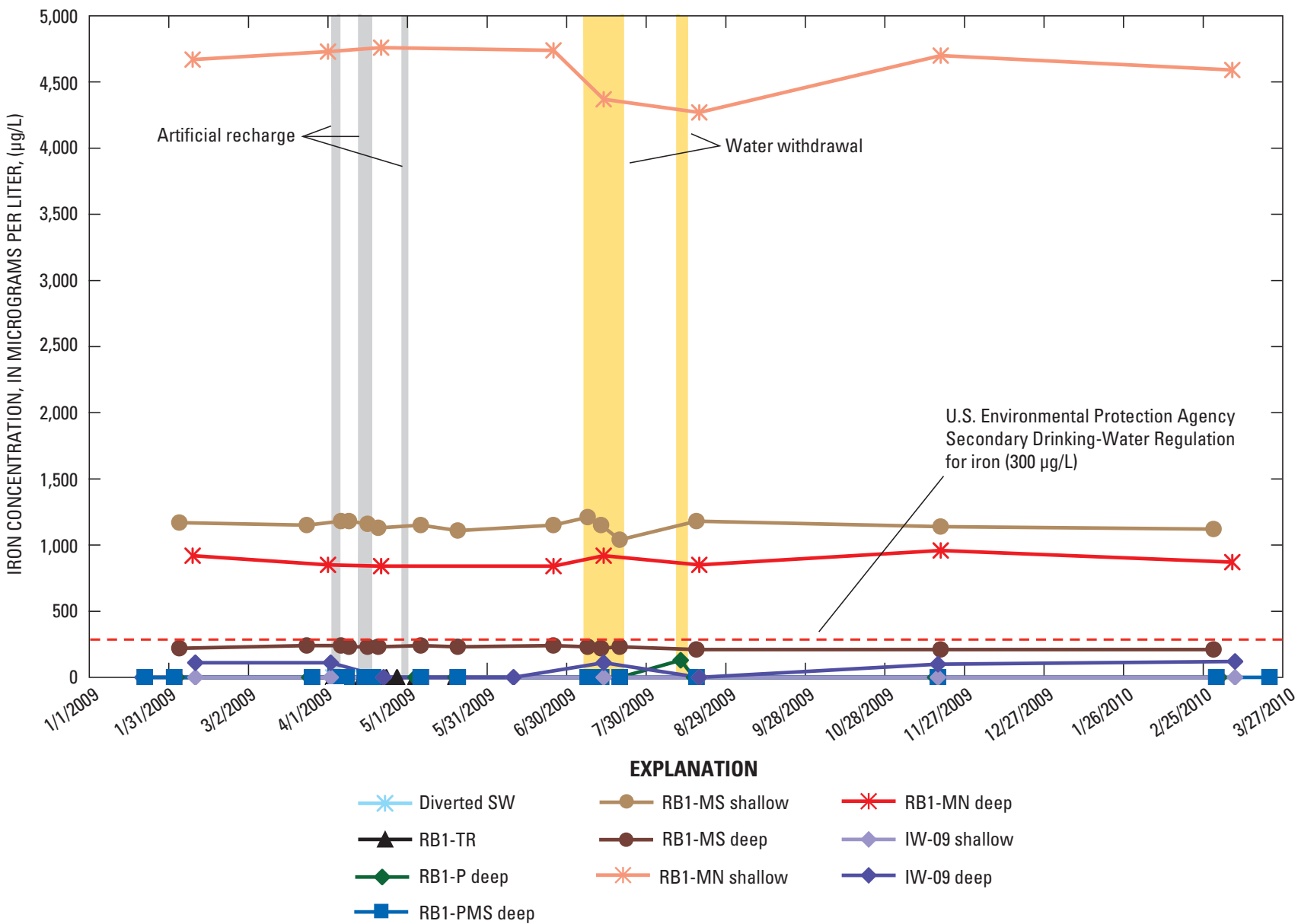

Figure 13. Measured iron concentrations in water samples collected from RB1 monitoring sites, January 2009 through March 2010.

other parts of the aquifer with greater concentrations of arsenic replaced water being pumped out. The oxygenated source water and rainwater that infiltrated into the aquifer at RB1 did not cause substantial changes in arsenic concentrations in any well in the RB1 area.

\section{Iron}

Iron is a constituent of concern in the Equus Beds aquifer. Water containing excessive concentrations of iron is unpleasant to drink because of odor, metallic taste, and rusty color. The SDWR for iron is $300 \mu \mathrm{g} / \mathrm{L}$ (U.S. Environmental Protection Agency, 2005). At concentrations exceeding the USEPA SDWR, iron forms red hydroxide precipitates in water that stain laundry and plumbing fixtures. Iron dissolved in groundwater is greatly affected by environmental conditions, especially ORP and $\mathrm{pH}$ (Hem, 1992), which in turn can be affected by the introduction of oxygenated recharge water. Bacterial activity also may affect the concentration of iron in water (Hem, 1992) and can be of particular concern in artificial recharge operations. The addition of oxygenated water to a system can create favorable conditions for increased bacterial activity, which can produce biofilms that can clog well screens (Ross Schmidt and others, 2007).

Concentrations of iron in water RB1 samples collected before artificial recharge range from below the reporting level of $100 \mu \mathrm{g} / \mathrm{L}$ (RB1-P (shallow and deep sampling depths), RB1-PMS shallow) to 4,670 $\mu \mathrm{g} / \mathrm{L}$ (MN shallow) (fig. 13). Samples from RB1 recharge water contained no measurable iron in solution. During artificial recharge, iron concentrations in all wells remained similar. Groundwater samples from RB1-MN shallow, RB1-MN deep, and RB1-MS shallow wells maintained concentrations of dissolved iron greater than the SDWR of $300 \mu \mathrm{g} / \mathrm{L}$, and those from RB1-TR, RB1-P well (shallow and deep sampling depths), RB1-PMS wells, RB1-MS deep and IW-09 wells were less than the SDWR with detections ranging from no detection to $240 \mu \mathrm{g} / \mathrm{L}$. Iron concentrations in groundwater samples collected after artificial recharge and before water withdrawal remained similar for each site; however, IRB BART suggest that IRB populations are affected and are more aggressive after recharge. This indicates artificial recharge may result in some clogging of well screens at locations with similar geochemistry. 


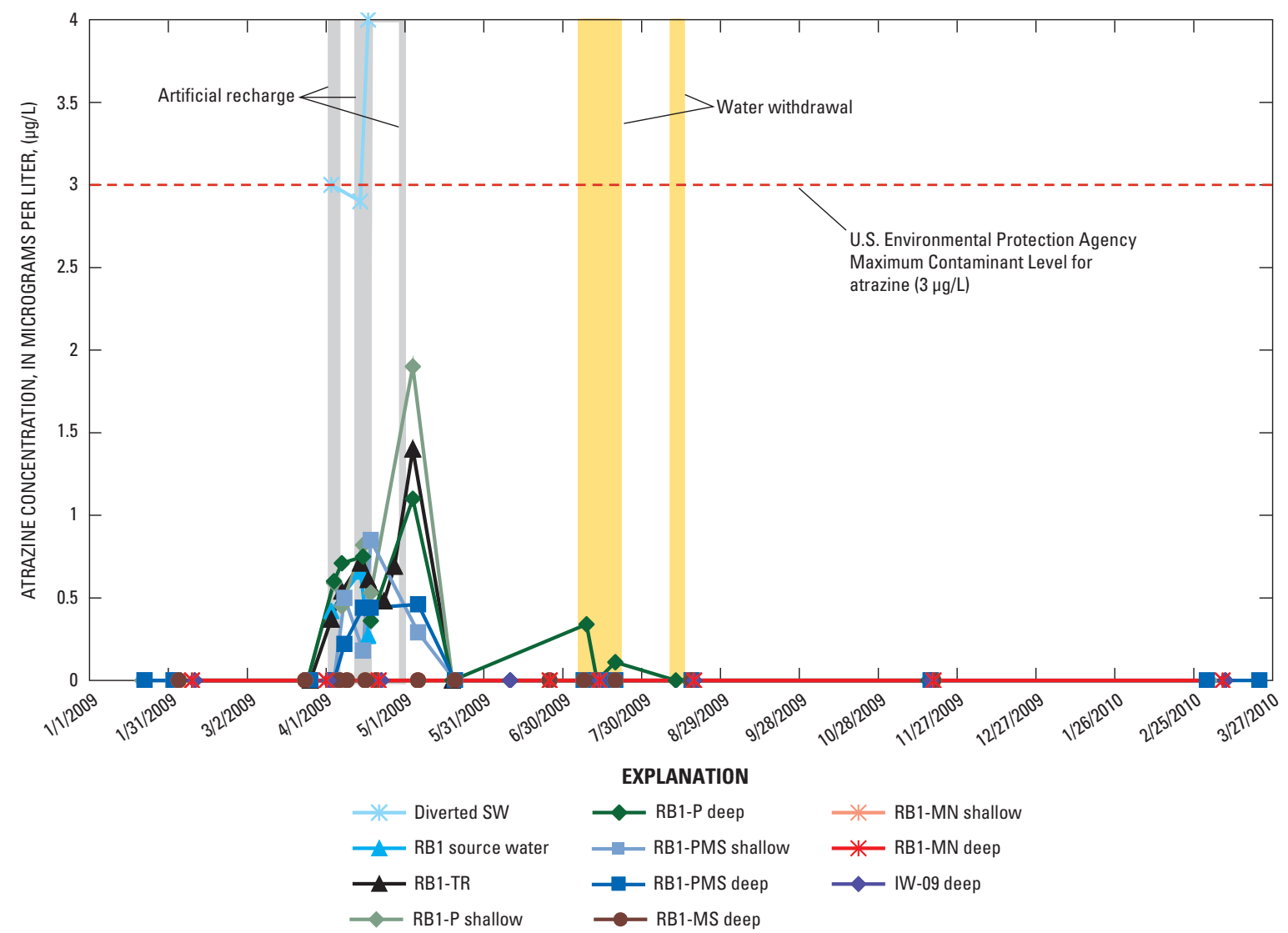

Figure 14. Measured atrazine concentrations in water samples collected from RB1 monitoring sites, January 2009 through March 2010.

\section{Atrazine}

Atrazine is a manmade herbicide used for control of broadleaf and grassy weeds in food crops such as corn and grain sorghum. It does not occur naturally in the environment. Atrazine can cause damage to internal organs in humans (USEPA Web site $h t t p: / / w w w . e p a . g o v / o g w d w 000 / p d f s / f a c t-$ sheets/soc/tech/altrazine.pdf). The Federal MCL in drinking water for atrazine is $3.0 \mu \mathrm{g} / \mathrm{L}$ as an annual average (U.S. Environmental Protection Agency, 2006a). The USEPA continues to investigate atrazine as a potential carcinogen (U.S. Environmental Protection Agency, 2009). Atrazine concentrations in samples collected from RB1 sites during the passive recharge well system test period did not exceed the MCL of $3 \mu \mathrm{g} / \mathrm{L}$.

Atrazine was not detectable in RB1 groundwater samples collected before artificial recharge. Diverted SW samples had atrazine concentrations ranging from 2.9 to $4 \mu \mathrm{g} / \mathrm{L}$ in three samples collected on April 3, 14, and 17, 2009. Concentrations of atrazine in samples of RB1 source water used for artificial recharge were .27 to $.66 \mu \mathrm{g} / \mathrm{L}$, indicating that water treatment removed much ( 77 to 93 percent) of the atrazine. During passive recharge, water samples from RB1-TR, RB1-P well (shallow and deep sampling depths), and RB1-PMS wells had concentrations of atrazine from .22 to $.85 \mu \mathrm{g} / \mathrm{L}$. Atrazine was not detected in the RB1-MS, RB1-MN, and IW-09 wells during passive recharge (fig. 14).

Samples collected 5 days after passive recharge was discontinued on May 4 and 5 from RB1-TR, RB1-P well (shallow and deep sampling depths), and RB1-PMS wells contained the largest concentrations of atrazine detected in the RB1 sites. Concentrations of atrazine measured in samples collected on May 4 and 5 had values from .29 to $1.9 \mu \mathrm{g} / \mathrm{L}$.

Samples were not collected from Diverted SW or from RB1 source water after April 17, 2009; therefore, the concentration of atrazine in the recharge water used for the third recharge period is not known. However, the concentration of atrazine in the Little Arkansas River at Hwy 50 near Halstead was $4.4 \mu \mathrm{g} / \mathrm{L}$ on April 28, 2009, $5.0 \mu \mathrm{g} / \mathrm{L}$ on April 30, 2009 , and $2.5 \mu \mathrm{g} / \mathrm{L}$ on May 4, 2009. If the treatment process removed 75 percent of the atrazine the concentration in the recharge water would have been about .62 to $1.25 \mu \mathrm{g} / \mathrm{L}$, which is less than the concentration measured in the samples. Field notes indicate that although RB1 source water was not being pumped into the basin, there was standing water in the basin. Precipitation was recorded at the Little Arkansas near Halstead continuous monitoring site on May 2 and 3 (.09 and .14 inches respectively). It is likely that the standing 
water in the RB1 basin was a combination of recharge water from artificial recharge on April 30 and rainfall runoff.

Atrazine was not detected in any samples collected from RB1-TR, the RB1-P well (shallow and deep sampling depths), or the RB1-PMS wells on May 19 and 20. There was no detection of atrazine in the RB1-MS, RB1-MN, or IW-09 wells during the period after recharge and before water withdrawal.

During water withdrawal, small concentrations (.34 and $.11 \mu \mathrm{g} / \mathrm{L}$ ) of atrazine were detected in samples collected of the withdrawn water (labeled RB1-P deep well on fig. 14). There were no detections in samples from other sites during water withdrawal, and there were no detections from any samples collected after water withdrawal was complete (August 2009 through March 2010).

\section{Geochemical Simulations}

Many of the changes in mineral saturation indices can be explained by changes in $\mathrm{pH}$. In general, the $\mathrm{pH}$ fluctuated at all sites during recharge, after artificial recharge and before water withdrawal, and during water withdrawal. The $\mathrm{pH}$ of recharge water was 5.9 on April 3, 2009, and increased rapidly to a value of 7.7 on April 14, 2009. It then decreased again to a value of 6.9 on April 17, 2009. This rapid increase and decrease caused associated changes in $\mathrm{pH}$ in the RB1 measurement sites, especially RB1-TR and RB1-P well (shallow and deep sampling depths). Additionally, while the trench and passive well were operational (January 1 through July 8, 2009) rainfall infiltration may have caused a decrease in $\mathrm{pH}$. During water withdrawal, $\mathrm{pH}$ also fluctuated, especially in the withdrawn water (labeled RB1-P deep well during this time period on all figures)

Saturation indices with respect to calcite (fig. 15A) generally indicated calcite undersaturation at all sites, indicating the potential for calcite dissolution if calcite is present; however, saturation indices for samples on June 25, 2009, at RB1MS deep well, July 20, 2009, at RB1-P well (deep sampling depth), and Novermber 17, 2009, at RB1-MN deep well and IW-09 deep well indicate the potential for calcite precipitation. Calcite saturation indices generally increased at all sites during artificial recharge, although overall the water remained undersaturated with respect to calcite. This is likely a result of increased $\mathrm{pH}$ values; the calcite saturation indices closely mirrored the sample $\mathrm{pH}$ measurements. In conjunction with the saturation index peaks during artificial recharge, the changing $\mathrm{pH}$ of $\mathrm{RB} 1$ source water indicates that mixing recharge water with aquifer water may have changed the water chemistry at RB1 sites, if only temporarily. All calculated saturation indices are provided in table 10 at the back of this report.

Saturation indices with respect to iron hydroxide (fig. 15B) indicate, in general, the water was undersaturated at RB1 source water, RB1-TR, RB1-P well (shallow and deep sampling depths), RB1-PMS shallow and deep wells, and IW-09 shallow and deep wells for most of the sampling period. Dissolved iron concentrations at these sites were equal to or near the reporting level and did not vary substantially; any changes in the saturation indices are likely because of changes in sample $\mathrm{pH}$. Iron hydroxide saturation indices for RB1-MN shallow and deep and RB1-MS shallow and deep indicate the water was oversaturated with respect to iron hydroxide and there is potential for iron hydroxide precipitation. Greater dissolved iron concentrations at these sites are the reason for oversaturation. Dissolved iron concentrations at these four sites remained relatively steady throughout the sampling period, so differences in the saturation indices are likely because of small variations in dissolved iron concentration and variations in $\mathrm{pH}$. However, if iron hydroxide precipitates and there is no direct source of dissolved iron, the observed dissolved iron concentrations should decrease. Because the observed dissolved iron concentrations remained relatively steady, iron hydroxide precipitation may have occurred if the surrounding aquifer acts as a source for dissolved iron. As with calcite, saturation indices with respect to iron hydroxide increased for all sites during artificial recharge because of increasing $\mathrm{pH}$ in the source water.

Similar to calcite, saturation indices with respect to manganite (fig. 15C) indicate the water was undersaturated at all sites, and there is the potential for manganite to dissolve if it is present. The dissolved manganese concentrations were more variable than dissolved iron and arsenic concentrations. Sample $\mathrm{pH}$ measurements more closely reflected the manganite saturation indices than did dissolved manganese concentrations. Like calcite and iron hydroxide, manganite saturation indices at all sites increased during artificial recharge, again possibly indicating a temporary change in the water chemistry likely because of the introduction of recharge water.

Saturation indices with respect to scorodite (fig. 15D) indicate the water was undersaturated at all sites. If scorodite is present, scorodite dissolution might occur and arsenic could be released to the aquifer. The presence of scorodite, though, is unlikely as it is too soluble under the conditions at the RB1 sites; however, scorodite saturation indices generally seem to decrease during the period of artificial recharge. This may indicate the changes in water chemistry associated with mixing recharge water with aquifer water cause the water to become less saturated for scorodite, which is opposite to the trends observed for calcite, iron hydroxide, and manganite in the same period.

Calcite and iron hydroxide precipitation and aquifer pore clogging are the primary concerns. In general, the saturation indices with respect to calcite and iron hydroxide increased in the study period. The calcite and iron hydroxide saturation indices indicate that calcite and iron hydroxide might have precipitated during the study period at some sites, and the potential for precipitation may be increasing. If calcite or iron hydroxide precipitation occurs, some aquifer pores may become clogged. The saturation indices with respect to manganite indicate that the potential for manganite dissolution is decreasing. If the trend were to continue, manganite might begin to precipitate and contribute to clogging of aquifer pores. The dissolution of scorodite is unlikely to have occurred 

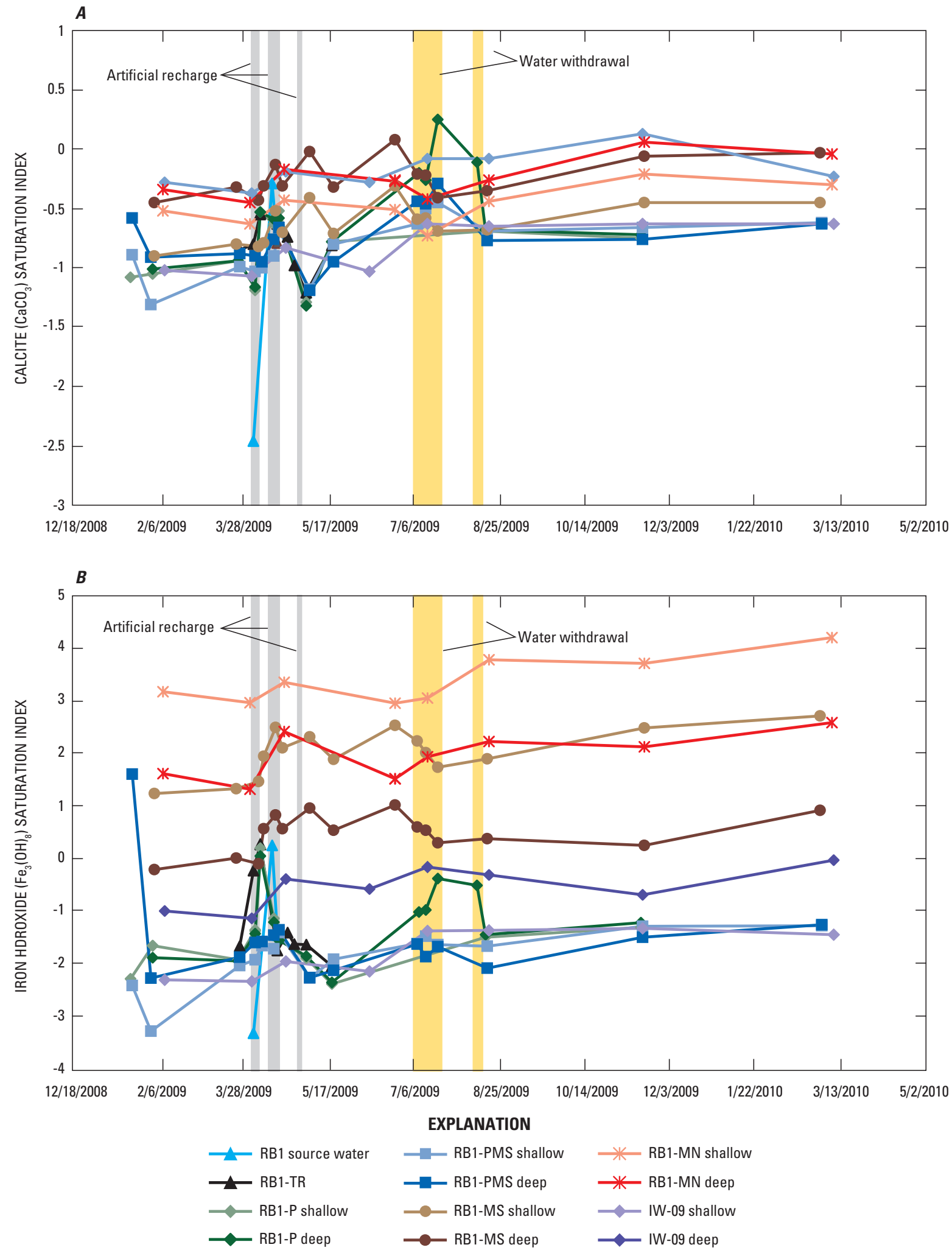

Figure 15. Saturation indices with respect to: $(A)$ calcite $(B)$ iron hydroxide $(C)$ manganite $(D)$ scorodite calculated for groundwater samples collected from RB1 site, 2009-2010. 

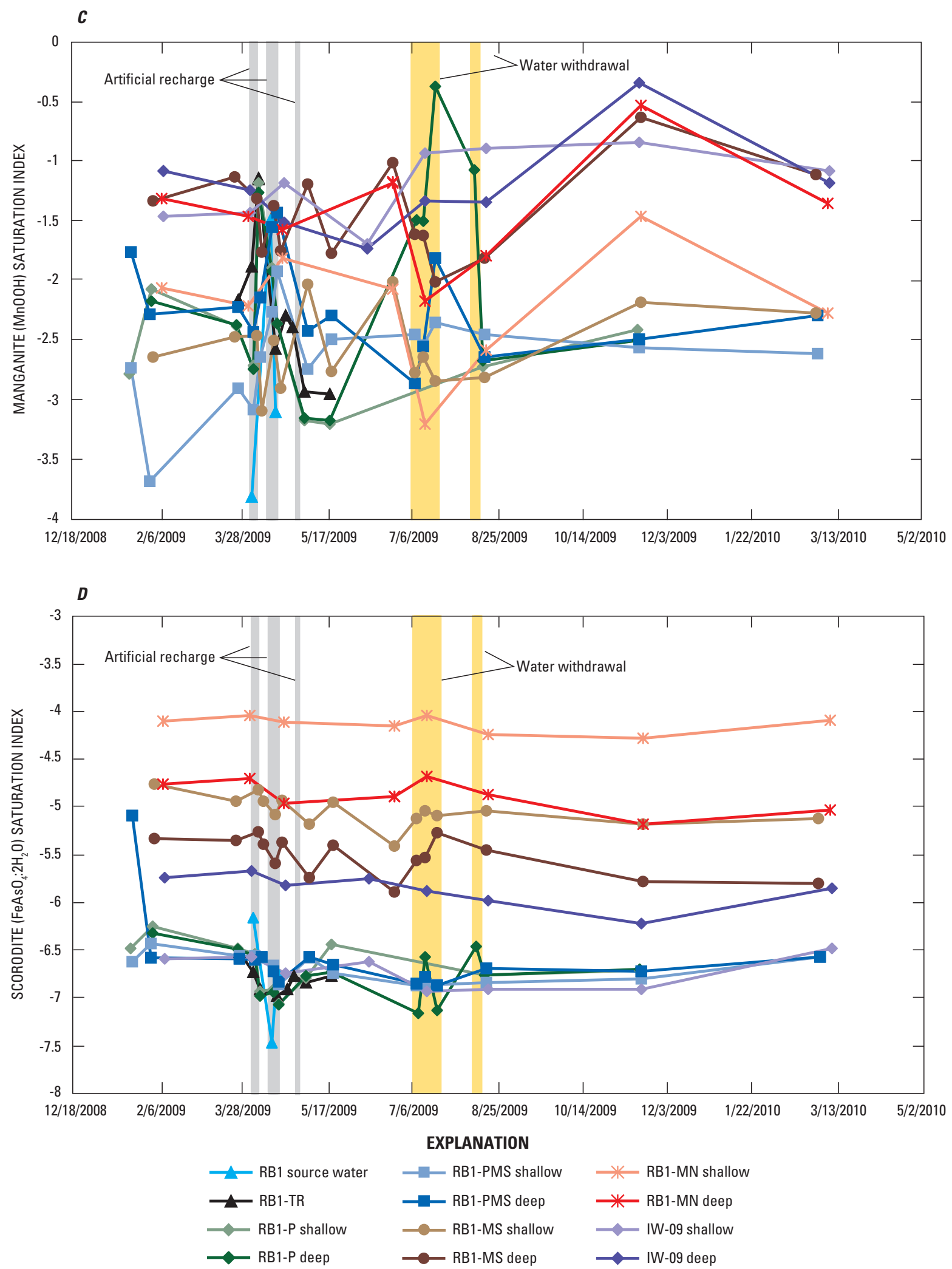

Figure 15. Saturation indices with respect to: $(A)$ calcite $(B)$ iron hydroxide $(C)$ manganite $(D)$ scorodite calculated for groundwater samples collected from RB1 site, 2009-2010.-Continued 
during the study period because its presence in the aquifer is unlikely.

Variations in saturation indices for calcite, iron hydroxide, manganite, and scorodite seem largely a result of changes in factors like $\mathrm{pH}$ rather than differences in dissolved concentrations of calcium, iron, manganese, and arsenic. Changes in $\mathrm{pH}$ throughout the period of artificial recharge likely occurred because of the introduction of recharge water.

\section{Effects of Experimental Passive Artificial Recharge: Synthesis}

Five distinct periods have been identified during the passive recharge experiment at RB1; before artificial recharge, during artificial recharge, after artificial recharge and before water withdrawal, during water withdrawal, and after water withdrawal. Piper diagrams show little change in water composition throughout the course of the experiment in IW-09 shallow, IW-09 deep (except for the sample collected on March 9, 2010 reporting a higher percentage of chloride), RB1-MN shallow, RB1-MN deep, RB1-MS shallow, and RB1-MS deep. Iron concentrations for individual sites remain similar throughout the study period. Saturation indices indicate that, in general, water is undersaturated with respect to calcite, iron hydroxide, manganite, and scorodite. The exception is that water samples from RB1-MN shallow and deep and RB1-MS shallow wells were oversaturated with respect to iron hydroxide during the entire study period, and that water samples from RB1-P well (deep sampling depth) were oversaturated with respect to calcite during water withdrawal. Changes in water properties that occurred as a result of the passive artificial recharge include changes in $\mathrm{DO}, \mathrm{ORP}, \mathrm{pH}$, water level, the populations of bacterial and viral indicators, and concentrations of major ions, trace elements, and organic constituents. A summary of the changes that occurred during the five periods follows.

\section{Before Artificial Recharge (January 1 Through April 2, 2009)}

Before treated surface water was introduced into the system, some surface water entered the trench and passive well system when rain fell into the basin area. Water-level altitude did not change substantially in any RB1 wells except RB1-MS deep. Large water-level changes in RB1-MS deep are related to nearby pumping and not related to artificial recharge. There were some detections of bacteria in groundwater from RB1-P well (shallow and deep sampling depths), RB1-PMS shallow and deep wells, and RB1-MS shallow well. IRB and SRB were detected in BART in samples from all sampled locations.

The piper diagram (fig. 10A) shows that the water generally includes a large amount of calcium and bicarbonate. There were no detections of atrazine in any RB1 samples collected in January, February, or March of 2009. Water samples from RB1-MN deep, RB1-MS deep, and IW-09 deep wells had dissolved arsenic concentrations above the MCL of $10 \mu \mathrm{g} / \mathrm{L}$. ORP was 100-200 $\mathrm{mV}$ in samples collected from the RB1MS shallow and deep wells, the RB1-MN shallow and deep wells, and the IW-09 deep well. ORP was near 400-500 $\mathrm{mV}$ in samples collected from RB1-TR, the RB1-P well (shallow and deep sampling depths), and the RB1-PMS wells.

The RB1-PMS deep well was drilled in January 2009, and is screened through the shallow and deep zones of the aquifer. The first set of samples collected from the RB1-PMS deep well have chloride, arsenic, and ORP concentrations similar to other deep wells, but subsequent samples are similar to the RB1-PMS shallow well. Profiles of physical properties and water levels (figs. 4 and $5 A$ ) indicate that water flows down the well from the shallow to the deep zone. This indication is supported by changing ORP, chloride concentrations, and arsenic concentrations in the RB1-PMS deep well (figs. 6, 11, and 12).

\section{During Artificial Recharge (April 3 Through April 30, 2009)}

During artificial recharge water levels increased rapidly in the RB1-P well and more slowly in the RB1-PMS wells when recharge water was added to the trench (fig. 5). ORP in these wells increased to values similar to RB1 source water (about $500 \mathrm{mV}$ ). Continuous monitors in RB1-TR, the RB1-P well (shallow and deep monitoring depths), and the RB1-PMS shallow and deep wells recorded a substantial increase in DO during artificial recharge because of the influx of oxygenated recharge water (table 5).

Coliform bacteria, fecal coliform bacteria, E. coli bacteria, coliphage virus, and clostridium perfringens bacteria were present in RB1 source water, and were detected in RB1-TR, the RB1-P well ( shallow and deep sampling depths), and RB1-PMS shallow and deep well samples (figs. 7 and 8, table 6). The percentage of samples with BART detections of iron-related bacteria and sulfate-reducing bacteria increased, probably because of the presence of the bacteria in the recharge water. Larger sulfate concentrations (table 8) may have contributed to the greater aggressiveness of SRB in the BART.

Piper diagrams (fig. 10B) show that the water in most samples from RB1-TR and the RB1-P well (shallow and deep sampling depths) increased in sulfate and chloride content. Concentrations of chloride and atrazine in RB1-TR, the RB1-P well (shallow and deep sampling depths), and the RB1-PMS wells increased to values similar to RB1 source water. Concentrations of chloride and atrazine in water samples from other wells in the system (the RB1-MS wells, the RB1-MN wells, and the IW-09 wells) remained similar to values before artificial recharge. Concentrations of iron and arsenic did not change substantially from pre-recharge concentrations in any RB1 samples collected during recharge. Overall, the properties 
of the treated surface water used for artificial recharge affected the water quality in the aquifer nearest the point of recharge (RB1-TR, the RB1-P well (shallow and deep sampling depths), and the RB1-PMS wells).

\section{After Artificial Recharge and Before Water Withdrawal (May 1 Through July 6, 2009)}

After artificial recharge and before water withdrawal, water was entering the system from rainfall only. Water levels in RB1-TR, the RB1-P well, and the RB1-PMS shallow and deep wells remained the same or rose slightly in response to rainfall. Values of SC in RB1-TR and the RB1-P well (shallow and deep monitoring depths) decreased when precipitation fell into the basin (fig. 5C). A decrease in SC in the RB1-PMS shallow and deep wells was measured 1 to 3 days after the decrease in RB1-TR and the RB1-P well (shallow and deep monitoring depths). DO (fig. 5D) and ORP (fig. 6) measurements decreased in response to the limited influx of oxygenated water.

Bacteria were detected in samples collected from RB1TR, the RB1-P well (shallow and deep sampling depths), the RB1-PMS shallow and deep wells, and the RB1-MS shallow wells (fig. 7 and table 6). Coliphage virus was detected in the RB1-PMS shallow and deep wells in early May 2009 (fig. 8 and table 6). It is likely that the recharged water flowed downgradient from the RB1-P well to the RB1-PMS wells, transporting bacterial and viral indicators to the RB1-PMS wells. The percentage of samples with IRB and SRB detections from BART decreased slightly during the period after artificial recharge and before water withdrawal.

Chloride concentrations in all wells either returned to, or remained near, pre-recharge values. Arsenic and iron concentrations in water samples from all wells remained similar to values before and during artificial recharge. After artificial recharge and before water withdrawal, concentrations of atrazine in samples from RB1-TR and the RB1-P well (shallow and deep sampling depths) increased to values larger than the RB1 source water that had previously entered the system.

\section{During Water Withdrawal (July 7 Through 21, 2009 and August 11 Through 14, 2009)}

Detections of bacterial and viral indicators in the recharge water and groundwater at RB1 prompted the City of Wichita to withdraw water from the site to remove the recharged water. About 1,825,000 gal of groundwater (more than three times the amount recharged) were withdrawn through the RB1-P well and deposited in an adjacent basin to allow for slow infiltration back into the aquifer. Water-level altitude decreased in all wells in response to the water withdrawal (fig. $5 A$ ).

Total coliform bacteria were detected in samples collected from the RB1-PMS shallow and deep wells, the RB1-MS shallow and deep wells, and the withdrawn water (labeled RB1-P deep well on figures and tables during water withdrawal). Fecal coliform bacteria were detected in a sample from the withdrawn water. E. coli and coliphage virus were detected in the RB1-PMS shallow well water sample. (figs. 7 and 8 and table 6). Detections of enteric bacteria from BART also increased, but the percentage of samples with detections of well-fouling IRB bacteria decreased, possibly because of the aggressiveness of the enteric bacteria. SRB detections also increased and were more aggressive. The presence of bacteria in groundwater samples can be attributed to the presence of bacteria in the recharge water. It is also likely that continuous pumping from the RB1-P well during this time created a steep hydraulic gradient (cone of depression) that increased surface water (previously withdrawn water) influx through the bottom of the basin and trench.

Relative concentrations of major ions in the IW-09 shallow and deep wells, RB1-MN shallow and deep wells, and RB1-MS shallow and deep wells changed little (fig. 10) from previous periods. Concentrations of chloride increased (fig. 11), and the relative percentage of the chloride ion increased (fig. 10) in samples collected from the RB1-PMS shallow and deep wells and the withdrawn water. The concentration of chloride in a sample collected from the RB1-PMS deep well on July 20, 2009 was $150 \mathrm{mg} / \mathrm{L}, 20 \mathrm{mg} / \mathrm{L}$ greater than the greatest concentration measured in the RB1 source water. A mass-balance calculation (see "Chloride" section in this report) indicated that during water withdrawal, about $116,700 \mathrm{~g}(257 \mathrm{lb})$ more chloride was pumped out of the aquifer than was introduced by artificial recharge. Although the concentration of chloride in the July 20, 2009 sample collected from the RB1-PMS deep well is similar to the concentration in the RB1-MN shallow well (fig. 11), concentrations of iron and arsenic (figs. 12 and 13) are not similar. This suggests that the source of the water with a greater chloride concentration is not from the area of the RB1-MN shallow well, but possibly from the deep aquifer near the RB1-PMS deep well.

Arsenic concentrations increased slightly in some water samples, most notably the withdrawn water samples (labeled RB1-P deep well on fig. 12), and is likely because of the flow of water with greater concentrations of arsenic flowing toward the RB1-P well in response to pumping. Arsenic concentrations remained greater than the MCL of $10 \mu \mathrm{g} / \mathrm{L}$ in the RB1MS deep, RB1-MN deep, and RB1-MN deep wells.

Small concentrations of atrazine were detected in samples collected from the withdrawn water (labeled RB1-P deep on fig. 14). Atrazine was not detected in any other RB1 wells during water withdrawal.

\section{After Water Withdrawal (August 15, 2009 Through March 22, 2010)}

Water-level altitude increased in RB1-PMS shallow and deep wells and the RB1-MS shallow well after water withdrawal ceased (fig. 5A). In March 2010, water-level altitudes were similar to those before artificial recharge. There were 
detections of total coliform bacteria in water samples collected from RB1-P well (shallow and deep sampling depths), the RB1-PMS shallow and deep wells, and the RB1-MS shallow and deep wells immediately after water withdrawal stopped (late August, 2009). There were detections of total coliform bacteria in samples collected during November, 2009, from the RB1-PMS shallow and deep wells. Total coliform was detected in one sample collected during March 2010 from the RB1-PMS deep well. When the RB1-PMS deep well was resampled 2 weeks later, there were no detections of bacteria or viral indicators. There were no detections of bacteria or viral indicators in the most recent samples from all RB1 sites (figs. 7 and 8, and table 6). A shift in bacterial populations after water withdrawal was indicated by BART, with fewer detections of SRB and enteric bacteria and greater detections of well-fouling IRB bacteria - similar to conditions before artificial recharge began.

Major ion chemistry as shown on Piper diagrams (fig. 10E) became similar to conditions observed before artificial recharge began (fig. 10A). Concentrations of chloride in samples from all RB1 wells were similar to concentrations measured before recharge began. Atrazine was not detected in samples from any RB1 wells after water withdrawal. Arsenic concentrations were similar to pre-recharge conditions in RB1 groundwater samples collected in November, 2009, and increased by about $1.0-2.5 \mu \mathrm{g} / \mathrm{L}$ in all RB1 groundwater samples collected in March 2010. The cause of the increased concentration of arsenic is not clear because $\mathrm{pH}$ or ORP values remained nearly constant after water withdrawal stopped at RB1.

\section{Summary and Conclusions}

The Equus Beds aquifer is a primary water supply source for Wichita, Kansas, and the surrounding area. Declining water levels in some parts of the Equus Beds aquifer and concerns about migration of a known saltwater plume upgradient from public supply wells prompted the City of Wichita to investigate the feasibility of using artificial recharge to replenish the water supply in the aquifer. A demonstration project conducted from 1995 to 2002 determined that the sources of recharge water were chemically compatible with the receiving groundwater, and in 2007 full-scale recharge began.

Recharge Basin 1 (RB1) was originally designed as a recharge basin into which treated surface water was to be discharged; however, because of greater than expected clay content in the bottom material of the basin, the infiltration rate of recharge water was less than required. Observation of recharge at RB1 during artificial recharge in 2007 and 2008 indicated the recharge capacity to be about $10.8(\mathrm{gal} / \mathrm{d}) / \mathrm{ft}^{2}$, "substantially less" than the design rate of $37.4(\mathrm{gal} / \mathrm{d}) / \mathrm{ft}^{2}$. The basin was reconstructed to include a 6-inch diameter passive gravity recharge well and trench system to facilitate the transport of recharge water into the aquifer and from 2009 to
2010 the system was tested. Information to address concerns related to the effectiveness of a passive recharge system at removing atrazine and microbes from treated surface water before it enters the aquifer, potential for changes in the microbial population in the aquifer resulting from the introduction of oxygenated surface water, and the potential effectiveness of using artificial recharge to stop or slow the migration of a chloride plume is needed. To address these needs the USGS, in cooperation with the City of Wichita, conducted a supplemental investigation as part of the Equus Beds groundwater recharge project designed to evaluate flow of recharge water through an experimental passive gravity recharge well system. About 576,000 gal of treated surface water were recharged through the passive gravity recharge system into the Equus Beds aquifer during April 2009. In July 2009, when laboratory test results indicated that bacteria were entering the aquifer through the passive recharge well, the trench collection system was disconnected from the passive gravity recharge well and $1,825,000$ gal of water were pumped out of the aquifer through the passive gravity recharge well in July and August, 2010. The water was deposited in a part of the RB1 basin separated from the passive gravity recharge well and trench by a berm.

Water samples were collected from Diverted SW, the RB1 source water, RB1-TR, the RB1-P well (shallow and deep sampling depths), the RB1-PMS shallow and deep wells, the RB1-MS shallow and deep wells, the RB1-MN shallow and deep wells, and the IW-09 shallow and deep wells . Continuous water-quality and water-level monitors were installed in RB1-TR, the RB1-P well (shallow and deep monitoring depths), the RB1-PMS shallow and deep wells, and the RB1MS shallow and deep wells during 2009-2010.

Continuous monitors recorded rising water-level altitudes in the RB1-P well (shallow and deep monitoring depths) (4.5 ft increase in altitude during artificial recharge) and nearby RB1-PMS and RB1-MS well pairs (about $1 \mathrm{ft}$ rise from April to July) during artificial recharge and precipitation events. The increase in water-level altitude decreased the hydraulic gradient to the west (upgradient) which would have the effect of slowing eastern migration of a known saltwater plume. The recharge rate in the original basin configuration at RB1 was about $10.8(\mathrm{gal} / \mathrm{d}) / \mathrm{ft}^{2}$. After installation of the passive recharge system, recharge water flowed through the sand filled filtration trench and entered the aquifer through the 6-inch passive well at a rate of about $19.2(\mathrm{gal} / \mathrm{d}) / \mathrm{ft}^{2}$. Recharge per unit area into the aquifer through the trench and passive gravity recharge well increased about 78 percent.

Turbidity values recorded by continuous monitors in the passive gravity recharge well increased immediately after artificial recharge and precipitation events indicating that turbid water was entering the passive gravity recharge well through the trench. Specific conductance values recorded by continuous monitors indicate larger specific conductance values during artificial recharge with treated surface water and smaller specific conductance values after precipitation entered the system. The decrease in specific conductance because of rainfall events was used to trace the flow of water from the trench 
through the passive gravity recharge well to the monitoring well pair about $30 \mathrm{ft}$ away in about 3 days.

Bacterial and viral indicators were detected in water samples collected before and after the installation of the passive gravity recharge well and trench system (when precipitation was the only source of recharge water), during artificial recharge with treated surface water, and after recharge. Large concentrations of total coliform, fecal coliform, Escherichia coli $(E$. coli), and coliphage virus were detected in the treated surface water used for recharge. The trench system at the RB1 passive recharge site did not remove all bacteria and viruses from water before water entered the aquifer. After the trench and passive gravity recharge well were disconnected and water was removed from the aquifer, detections of bacteria and indicator viruses decreased to concentrations similar to those before installation of the passive recharge system. Iron-related bacteria and sulfate-reducing bacteria concentrations were similar in samples collected during all periods of the evaluation. Enteric bacteria were detected more often during artificial recharge and water withdrawal than before artificial recharge, after artificial recharge and before water withdrawal, and after water withdrawal.

Concentrations of chloride in samples collected from the trench, passive gravity recharge well, and nearby monitoring wells increased from an average of 34 milligrams per liter $(\mathrm{mg} / \mathrm{L})$ before artificial recharge to an average of $64 \mathrm{mg} / \mathrm{L}$ during artificial recharge, reflecting the addition of recharge water with measured concentrations of 62 to $94 \mathrm{mg} / \mathrm{L}$. When water was pumped out of the RB1 site through the RB1-P well, chloride concentrations increased to $94 \mathrm{mg} / \mathrm{L}$ in the extracted water. During water withdrawal chloride concentrations increased $(40-150 \mathrm{mg} / \mathrm{L})$ in the RB1-PMS deep well, even though a mass balance indicates that an additional $116,700 \mathrm{~g}$ $(257 \mathrm{lb})$ more chloride was removed from the aquifer than was added by artificial recharge water. The large chloride concentration in the RB1-PMS deep well of $150 \mathrm{mg} / \mathrm{L}$ and the massbalance calculation suggest that as water was being pumped out of the RB1-P well, water with a large chloride concentration from elsewhere in the aquifer was flowing toward the RB1-P and RB1-PMS wells. Chloride concentrations did not exceed the United States Environmental Protection Agency (USEPA) Secondary Drinking Water Regulation (SDWR) of $250 \mathrm{mg} / \mathrm{L}$.

Passive artificial recharge and water withdrawal did not cause large changes in iron or arsenic concentrations in the RB1 wells. In the treated surface water used for artificial recharge, arsenic concentrations were less than the USEPA Maximum Contaminant Level (MCL) of $10 \mu \mathrm{g} / \mathrm{L}$ and iron concentrations were less than the SDWR of $300 \mu \mathrm{g} / \mathrm{L}$.

Atrazine concentrations in samples from RB1 sites did not exceed the USEPA MCL of $3 \mu \mathrm{g} / \mathrm{L}$. Atrazine concentrations in diverted surface water were greater than the USEPA MCL, but those in the treated water were less than the MCL, indicating the treatment process effectively reduced the concentration of atrazine in the recharge water. Atrazine concentrations in RB1 wells increased during artificial recharge with treated water, and after artificial recharge when precipitation was the only source of water to the passive recharge system. Concentrations of atrazine in RB1 wells returned to values similar to pre-recharge conditions after passive recharge was discontinued and water withdrawal was complete.

Saturation indices indicate the potential for calcite $\left(\mathrm{CaCO}_{3}\right)$ precipitation in one sample each at four deep wells during the study period. Calcite precipitation may cause the clogging of aquifer pores. Saturation indices indicate that water was oversaturated with respect to iron hydroxide $\left(\mathrm{Fe}_{3}(\mathrm{OH})_{8}\right)$ at RB1-MN shallow and deep, and RB1MS shallow and deep wells, and precipitation may have occurred. Water was undersaturated with respect to scorodite $\left(\mathrm{FeAsO}_{4}: 2 \mathrm{H}_{2} \mathrm{O}\right)$ and manganite $(\mathrm{MnOOH})$ and would likely have dissolved at the RB1 sites if either were present in aquifer material. During artificial recharge, saturation indices for calcite, iron hydroxide, and manganite increased while saturation indices for scorodite decreased, indicating that mixing artificial recharge water with aquifer water affected the water chemistry. Variations in saturation indices likely occurred because of changes in $\mathrm{pH}$, which could be affected by artificial recharge or rainfall events.

\section{References Cited}

Anders, R., and Schroeder, R.A., 2003, Use of water-quality indicators and environmental tracers to determine the fate and transport of recycled water in Los Angeles County, California: U.S. Geological Survey Water-Resources Investigations Report 03-4279, 104 p.

Anders, R., Yanko, W.A., Schroeder, R.A., and Jackson, J.L., 2004, Virus fate and transport during recharge using recycled water at a research field site in the Montebello Forebay, Los Angeles County, California, 1997-2000: U.S. Geological Survey Scientific Investigations Report 2004-5161, $74 \mathrm{p}$.

Armon, R., and Payment, P., 1988, A modified m-CP medium for enumerating Clostridium perfringens from water samples: Canadian Journal of Microbiology, v. 34, p. 78-79.

Aucott, W.R., Myers, N.C., and Dague, B.J., 1998, Status of groundwater levels and storage in the Wichita well field area, south-central Kansas, 1997: U.S. Geological Survey Water-Resources Investigations Report 98-4095, 15 p.

Barcina, I., Lebaron, P., and Vives-Rego, J., 1997, Survival of allochthonous bacteria in aquatic systems: a biological approach: FEMS Microbiology Ecology, v. 23, p. 1-9.

Bauder, T.A., Waskom, R.M., and Davis, J.G., 2007, Irrigation water quality criteria: Colorado State University Extension, information available on Web, accessed June 16, 2010, at http://www.ext.colostate.edu/PUBS/crops/00506.html. 
Bisson, J.W.,and Cabelli, V.J., 1979, Membrane filter enumeration method for Clostridium perfringens: Applied and Environmental Microbiology, v. 37, no. 1, p. 55-66.

Bisson, J.W., and Cabelli, V.J., 1980, Clostridium perfringens as a water pollution indicator: Journal of the Water Pollution Control Federation, v. 52, no. 2, p. 241-248.

Blanford,W.J., Brusseau, M.L., Jim Yeh, T.C., Gerba, C.P., and Harvey, R., 2005, Influence of water chemistry and travel distance on bacteriophage PRD-1 transport in a sandy aquifer: Water Research, v. 39, p. 2,345-2,357.

Britton, L.J., and Greeson, P.E., eds, 1987, Methods for collection and analysis of aquatic biological and microbiological samples: U.S. Geological Survey Techniques of WaterResources Investigations, book 5, chap. A4, 363 p.

Byrd, J.J., Xu, H., and Colwell, R.R., 1991, Viable but nonculturable bacteria in drinking water: Applied and Environmental Microbiology, v. 57, p. 875-878.

Charles, K.J., Shore, J., Sellwood, J., Laverick, M., Hart, A., and Pedley, S., 2009, Assessment of the stability of human viruses and coliphage in groundwater by PCR and infectivity methods: Journal of Applied Microbiology, v. 106, p. $1,827-1,837$.

Childress, C.J.O., Foreman, W.T., Connor, B.F., and Maloney, T.J., 1999, New reporting procedures based on longterm method detection levels and some considerations for interpretations of water-quality data provided by the U.S. Geological Survey National Water-Quality Laboratory: U.S. Geological Survey Open-File Report 99-193, 19 p.

Christensen, V.G., Jian Xiaodong, and Ziegler, A.C., 2000, Regression analysis and real-time water-quality monitoring to estimate constituent concentrations, loads, and yields in the Little Arkansas River, south-central Kansas, 1995-99: U.S. Geological Survey Water-Resources Investigations Report 00-4126, 36 p.

Christensen, V.G., Ziegler, A.C., Rasmussen, P.P., and Jian Xiaodong, 2003, Continuous real-time water-quality monitoring of Kansas streams, in Proceedings of 2003 Spring Specialty Conference on Agricultural Hydrology and Water Quality, May 12-14, 2003, Kansas City, Missouri: Middleburg, Virginia, American Water Resources Association Technical Publication Series No. TPS-03-1, compact disc.

Cook, K.L., and Bolster, C.H., 2007, Survival of Campylobacter jejuni and Escherichia coli in groundwater during prolonged starvation at low temperatures: Journal of Applied Microbiology, v. 103, p. 573-583.

Covert, T.C, Rice, E.W., Johnson, S.A., Berman, .D., Johnson C.H., and Mason, P.J., 1992, Comparing defined-substrate coliform tests for the detection of Escherichia coli in water: American Water Works Association, v. 84, no. 5, p. 98-104.
Cullimore, D. Roy, 2007, Practical manual of groundwater microbiology (2d edition): Boca Raton, Fl., CRC Press, $376 \mathrm{p}$.

Dillon, P., Toze, S., Pavelic, P., Vanderzalm,J., Barry, K., Ying, G., Kookana, R., Skjemstad, J., Nicholson, B., Miller, R., Correll, R., Prommer, H., Greskowiak, J., and Stuyfzand, P., 2005 , Water quality improvements during aquifer storage and recovery at ten sites: Proceedings, 5th International Symposium, Aquifer Recharge, Berlin, p. 86-93.

Droycon Bioconcepts Inc., 2004, Biological Activity Reaction Test BART ${ }^{\mathrm{TM}}$ User Manual ${ }^{\circ} 2004$ Edition, accessed March 1, 2011, at http://www.dbi.ca/BARTs/Docs/Manual. $p d f$.

Equus Beds Groundwater Management District No. 2, 1990, Equus Beds Groundwater Management District No. 2 management program: Halstead, Kansas, 91 p.

Fedder, C.W., 1994, Applied Hydrology (3d ed.): Upper Saddle River, New Jersey, Prentice-Hall, 691 p.

Foppen, J.W.A., and Schijven, J.F., 2006, Evaluation of data from the literature on the transport and survival of Escherichia coli and thermotolerant coliforms in aquiers under saturated conditions: Water Research, v. 40, p. 401-426.

Guy, H.P., 1969, Laboratory theory and methods for sediment analysis: U.S. Geological Survey Techniques of WaterResources Investigations, book 5, chap. C1, 58 p.

Hansen, C.V., 2007, Status of ground-water levels and storage volume in the Equus Beds aquifer near Wichita, Kansas, January 2003-January 2006: U.S. Geological Survey Scientific Investigations Report 2006-5321, 34 p.

Hansen, C.V., and Aucott, W.R., 2004, Status of groundwater levels and storage volume in the Equus Beds aquifer near Wichita, Kansas, January 2000-January 2003: U.S. Geological Survey Water-Resources Investigations Report 03-4298, $36 \mathrm{p}$.

Hamilton, W.P., Moonil, K., and Thackston, E.L., 2005, Comparison of commercially available Escherichia coli enumeration tests: Implications for attaining water quality standards, Water Research: v. 39, p. 4,869-4,878.

Hem, J.D., 1992, Study and interpretation of chemical characteristics of natural water (3rd ed.): U.S. Geological Survey Water-Supply Paper 2254, $263 \mathrm{p}$.

John, D.E., and Rose, J.B., 2005, Review of factors affecting microbial survival in groundwater: Environmental Science \& Technology, v. 39, no. 19, p. 7,345-7,356.

Juracek and Hansen, 1995, Digital hypsography maps created from 1:100,000-scale digital line Graph hypsography data for Kansas: U.S. Geological Survey Open-File Report 95-448, digital data set. 
Kansas Department of Agriculture, 2009, Kansas farm facts 2009: Topeka, Kansas, 81 p.

Keswick, B.H, Gerba, C.P., Secor. S.L., and Cech, I., 1982, Survival of enteric viruses and indicator bacteria in groundwater: Journal of Environmental Science and Health, v. A17, no. 6, p. 903-912.

Keys, W.S., 1990, Borehole geophysics applied to groundwater investigations: U. S. Geological Survey Techniques of Water-Resources Investigations, book 2, chap. E2, 150 p.

Koterba, M.T., Wilde, F.D., and Lapham, W.W., 1995, Groundwater data-collection protocols and procedures for the National Water-Quality Assessment Program-collection and documentation of water-quality samples and related data: U.S. Geological Survey Open-File Report 95-399, $113 \mathrm{p}$.

McFeters, G.A., 1993, Chlorine injury and the comparative performance of Colisure, ColiLert, and ColiQuik for the enumeration of coliform bacteria and E. coli in drinking water: Water Science and Technology, v. 27, no. 3, p. 261-265.

McFeters, G.A., Broadaway, S.C., Pyle, B.H., Pickett, M., and Egozy, Y., 1995, Comparative performance of Colisure (TM) and accepted methods in the detection of chlorineinjured total coliforms and E. coli.: Water Science and Technology, v. 31, no. (5-6) p. 259-261.

Molz, F.J., Boman, G.K., Young, S.C., and Waldrop, W.R., 1994, Borehole flowmeters: field application and data analysis: Journal of Hydrology, v. 163, p. 347-371.

Myers, N.C., Haragadine, G.D., and Gillespie, J.B., 1996, Hydrologic and chemical interactions of the Arkansas River and the Equus Beds aquifer between Hutchinson and Wichita, south-central Kansas: U.S. Geological Survey Water-Resources Investigations Report 95-4191, 100 p.

Nevecherya, I.K, Shestakov, V.M., Mazaev, V.T., and Shlepnina, T.G., 2005, Survival rate of pathogenic bacteria and viruses in groundwater: Water Resources, v. 32, no. 2, p. 209-214.

Paillet, F.L., 2001, Hydraulic head appplications of flow logs in the study of heterogeneous aquifers: Ground Water, v. 39, no. 5, p. 667-675.

Parkhurst, D.L., and Appelo, C.A.J., 1999, User's guide to PHREEQC (version 2) - a computer program for speciation, batch-reaction, one-dimensional transport, and inverse geochemical calculations: U.S. Geological Survey WaterResources Investigations Report 99-4259, 312 p.
Payment, P., and Franco, E., 1993, Clostridium perfringens and somatic coliphages as indicators of the efficiency of drinking water treatment for viruses and protozoan cysts: Applied and Environmental Microbiology, v. 59, no. 8, p. $2,418-2,424$.

Puls, R.W., and Barcelona, M.J., 1996, Low-flow (minimal drawdown) groundwater sampling procedures: U.S. Environmental Protection Agency Groundwater Issue, EPA 540/S-95/504, 12 p.

Rasmussen, P.P., and Ziegler, A.C., 2003, Comparison and continuous estimates of fecal coliform and Escherichia coli bacteria in selected Kansas streams, May 1999 through April 2002: U.S. Geological Survey Water-Resources Investigations Report 03-4056, $80 \mathrm{p}$.

Roszak, D.B, and Colwell, R.R., 1987, Survival strategies of bacteria in the natural environment: Microbiological. Reviews, v. 51, p. 365-379.

Schmidt, H.C.R., Ziegler, A.C., and Parkhurst, D.L., 2007, Geochemical effects of induced stream-water and artificial recharge on the Equus Beds aquifer, south-central Kansas, 1995-2004: U.S. Geological Survey Scientific Investigations Report 2007-5025, 58 p.

Stramel, G.J., 1956, Progress report on the groundwater hydrology of the Equus beds area, Kansas: Kansas Geological Survey Bulletin 119, part 1, 59 p.

Stramel, G.J., 1962a, A review of the geology and hydrology of the Wichita well field: Wichita, Kansas, City of Wichita Water Department, $29 \mathrm{p}$.

Stramel, G.J., 1962b, A preliminary review of artificial recharge potential in the area between Hutchinson and Wichita, Kansas: Wichita, Kansas, City of Wichita Water Department, $21 \mathrm{p}$.

Stramel, G.J., 1967, Progress report on the groundwater hydrology of the Equus beds area, Kansas-1966: Kansas Geological Survey Bulletin 187, part 2, 27 p.

Thurman, E.M., Meyer, M.T., Pomes, M.L., Perry, C.A., and Schwab, A.P., 1990, Enzyme-linked immunosorbent assay compared with gas chromatography/mass spectrometry for the determination of triazine herbicides in water: Analytical Chemistry, v. 62, no. 18, p. 2,043-2,048.

U.S. Environmental Protection Agency, 1986, Quality criterion for water, 1986: U.S. Environmental Protection Agency Report 440/5-86-001, unnumbered pages.

U.S. Environmental Protection Agency, 1989, Drinking water; National Primary Drinking Water Regulations; Total Coliforms (including Fecal Coliforms and E. Coli) - final rule: Federal Register, v.54, no. 124, p. 27,544-568, accessed September 10, 2010, at http://water.epa.gov/lawsregs/rulesregs/sdwa/tcr/upload/tcr1989.pdf. 
U.S. Environmental Protection Agency, 1996, EPA Information Collection Rule microbial laboratory manual: Washington, D.C., EPA-600-R-95-178, section XI., accessed March 1, 2011, at http://www.epa.gov/microbes/online.html.

U.S. Environmental Protection Agency, 2000, Improved enumeration methods for the recreational water quality indicators-enterococci and Escherichia coli: Washington D.C., Office of Science and Technology, EPA 821-R-97-04, 40 p., accessed March 1, 2011 at http://www.epa.gov/microbes/ online.html.

U.S. Environmental Protection Agency, 2001a, Method 1602 - male-specific $(\mathrm{F}+)$ and somatic coliphage in water by single agar layer (SAL) procedure: Office of Water, Washington, D.C., EPA 821-4-01-029, 30 p., accessed March 1, 2011, at http://www.epa.gov/microbes/online.html.

U.S. Environmental Protection Agency, 2001b, National primary drinking water regulations - arsenic and clarifications to compliance and new source contaminants monitoringfinal rule: Federal Register, v. 66, no. 14, p. 6,975-7,066, accessed May 13, 2010, at http://www.epa.gov/fedrgstr/ EPA-WATER/2001/January/Day-22/w1668.htm.

U.S. Environmental Protection Agency, 2005, Current drinking-water standards: Information available on Web, accessed May 13, 2010, at $h t t p: / / w w w . e p a . g o v / s a f e w a t e r /$ mcl.html.

U.S. Environmental Protection Agency, 2006a, 2006 Edition of the drinking water standards and health advisories: Office of Water, EPA 822-R-06-013, August 2006, 12 p., accessed May 13, 2010, at http://www.epa.gov/waterscience/criteria/ drinking/dwstandards.html.

U.S. Environmental Protection Agency, 2006b, Method 1103.1-Escherichia coli (E. coli) in water by membrane filtration using membrane-thermotolerant Escherichia coli agar (mTEC): Washington, D.C., EPA 821-R-06-010, 45 p., accessed March 1, 2011, at http://www.epa.gov/ microbes/1103_1sp02.pdf.

U.S. Environmental Protection Agency, 2006c, Method 1106.1-Enterococci in water by membrane filtration using membrane enterococcus esculin iron agar (mE-EIA): Washington, D.C., EPA 821-R-06-008, 42 p., accessed April 26, 2011, at http://www.epa.gov/microbes/1106_1sp02.pdf.

U.S. Environmental Protection Agency, 2006d, Method 1600 - Enterococci in water by membrane filtration using membrane enterococcus indoxyl- $\beta$-D-glucoside agar ( $\mathrm{mEI})$ : Washington, D.C., EPA 821-R-06-009, 42 p., accessed April 26, 2011, at http://www.epa.gov/microbes/1600sp02. $p d f$.
U.S. Environmental Protection Agency, 2006e, Method 1603-Escherichia coli (E. coli) in water by membrane filtration using modified membrane-thermotolerant Escherichia coli agar (modified mTEC): Washington, D.C., EPA 821-R-06-011, 42 p., accessed April 26, 2011, at http:// www.epa.gov/microbes/1603sp02.pdf.

U.S. Environmental Protection Agency, 2009, EPA Begins New Scientific Evaluation of Atrazine, EPA News Release, October 7, 2009, accessed May 13, 2010 at http://yosemite. epa.gov/opa/admpress.nsf/d0cf6618525a9efb85257359003 fb69d/554b6abea9d0672f85257648004a88c1!OpenDocum ent.

U.S. Geological Survey, 2006, Collection of water samples (ver. 2.0): U.S. Geological Survey Techniques of WaterResources Investigations, book 9, chap. A4, September, accessed November 12, 2010 at http://pubs.water.usgs.gov/ twri9A4/.

U.S. Geological Survey, 2008a, Results for the Spring 2008 Inter-laboratory Comparison Study: Office of Water Quality, Branch of Quality Systems, Standard Reference Sample Project, accessed November 17, 2010, at http:// qadata.cr.usgs.gov/srs_study/reports/round_details. php?fy $=2008$ \&eason $=1$.

U.S. Geological Survey, 2008b, Results for the Fall 2008 Inter-laboratory Comparison Study: Office of Water Quality, Branch of Quality Systems, Standard Reference Sample Project, accessed November 17, 2010, at http:// qadata.cr.usgs.gov/srs_study/reports/round_details. php?fy $=2008 \&$ season $=2$.

Wagner, Richard J.; Boulger, Robert W., Jr.; Oblinger, Carolyn J.; and Smith, Brett A., 2006, Guidelines and standard procedures for continuous water-quality monitors: Station operation, record computation, and data reporting: U.S. Geological Survey Techniques and Methods 1-D3, 51 p.

Wang, D., and Fiessel, W., 2008, Evaluation of media for simultaneous enumeration of total coliform and Escherichia coli in drinking water supplies by membrane filtration techniques: Journal of Environmental Sciences, v. 20, p. 273-277.

Warren, D.R., Blain, G.T., Shorney, F.L., and Klein, L.J., 1995, IRP-A case study from Kansas: Journal of the American Water Works Association, p. 57-71.

Whittemore, D.O., 2007, Fate and identification of oil-brine contamination in different hydrogeologic settings: Applied Geochemistry: v. 22, no. 10, p. 2,099-2,114.

Wilde, F.D., and Radke, D.B., eds., 1998, Field measurements, in National field manual for the collection of water-quality data: U.S. Geological Survey Techniques of WaterResources Investigations, book 9, chap. A6, p. 3-20. 
Williams, C.C., and Lohman, S.W., 1949, Geology and groundwater resources of a part of south-central Kansas: Kansas Geological Survey, Bulletin 79, 455 p.

Wood, W.W., 1976, Guidelines for collection and field analysis of groundwater samples for selected unstable constituents: U.S. Geological Survey Techniques of Water-Resources Investigations, book 1, chap. D2, 24 p.

Ziegler, A.C., and Combs, L.J., 1997, Baseline data-collection and quality control protocols and procedures for the Equus Beds Groundwater Recharge Demonstration Project near Wichita, Kansas, 1995-96: U.S. Geological Survey OpenFile Report 97-235, $57 \mathrm{p}$.

Ziegler, A.C., Christensen, V.G., and Ross, H.C., 1999, Baseline water-quality and preliminary effects of artificial recharge on groundwater, south-central Kansas, 1995-98: U.S. Geological Survey Water-Resources Investigations Report 99-4250, 74 p.

Ziegler, A.C., Ross, H.C., Trombley, T.J., and Christensen, V.C., 2001, Effects of artificial recharge on water quality in the Equus Beds aquifer, south-central Kansas, 1995-2000: U.S. Geological Survey Fact Sheet 096-01, 4 p.

Ziegler, A.C., Hansen, C.V., and Finn, D.A., 2010, Water quality in the Equus Beds aquifer and the Little Arkansas River before implementation of large-scale artificial recharge, south-central Kansas, 1995-2005: U.S. Geological Survey Scientific Investigations Report 2010-5023, 143 p. 

Supplemental Information 
[ELISA, enzyme-linked immunosorbent assay; m-TEC, membrane-thermotolerant Escherichia coli; BART, Biological Activity Reaction Test; C13, E. coli culture resistant to naladixic acid and used to detect somatic coliphages; Famp, E. coli culture resistant to ampicillin and streptomycin and used to detect male-specific coliphages; MF, membrane filter]

\section{Physical properties, dissolved and suspended solids, and suspended sediment}

\begin{tabular}{|c|c|c|c|}
\hline Oxidation reduction potential & Specific conductance & Alkalinity, dissolved & \\
\hline Turbidity & Water temperature & Total dissolved solids & \\
\hline Oxygen, dissolved & Carbonate hardness, total & Suspended solids & \\
\hline $\mathrm{pH}$ & Hardness & Suspended sediment & \\
\hline \multicolumn{4}{|c|}{ Major ions and nutrients } \\
\hline Calcium, dissolved & Bicarbonate, dissolved & Fluoride, dissolved & Nitrite plus nitrate, dissolved \\
\hline Magnesium, dissolved & Carbonate, dissolved & Sulfate, dissolved & Phosphorous, dissolved \\
\hline Potassium, dissolved & Bromide, dissolved & Ammonia, dissolved & Orthophosphate, dissolved \\
\hline Sodium, dissolved & Chloride, dissolved & Nitrate, dissolved & Organic carbon, total \\
\hline \multicolumn{4}{|c|}{ Trace elements and organic compounds } \\
\hline Arsenic, dissolved & Iron, dissolved & Manganese, dissolved & Triazine screen, dissolved, ELISA \\
\hline \multicolumn{4}{|c|}{ Bacterial and viral indicators } \\
\hline Clostridium perfringens & Escherichia coli, m-TEC method & Iron-related bacteria, BART & \\
\hline Coliphage, Escherichia coli, C13 host & Fecal coliform & Sulfate-reducing bacteria, BART & \\
\hline Coliphage, Escherichia coli, Famp host & Total coliform & & \\
\hline $\begin{array}{l}\text { Escherichia coli, modified m-TEC } \\
\text { MF method }\end{array}$ & & & \\
\hline
\end{tabular}

MF method 
Table 5. Summary of physical property data from water samples collected as part of the Equus Beds Experimental Passive Recharge Project at RB1, $2009-2010$.

[mg/L, milligrams per liter; $\mu \mathrm{S} / \mathrm{cm}$, microsiemens per centimeter at 25 degrees Celsius; ${ }^{\circ} \mathrm{C}$, degrees Celsius; $+/-$, plus or minus; NTU, nephelometric turbidity units; NTRU, nephelometric turbidity ratiometric units; $\mathrm{mV}$, millivolts; $\mathrm{CaCO}_{3}$, calcium carbonate; --, not determined or not applicable; <, less than; $\mathrm{M}^{*}$, presence of material verified, but not quantified; $\mathrm{E}^{* *}$, estimated]

\begin{tabular}{|c|c|c|c|c|c|c|c|c|c|c|c|c|}
\hline $\begin{array}{c}\text { Date of } \\
\text { sample } \\
\text { collection } \\
\text { (month/day/ } \\
\text { year) }\end{array}$ & $\begin{array}{c}\text { Sample } \\
\text { start } \\
\text { time }\end{array}$ & $\begin{array}{c}\text { Dissolved } \\
\text { oxygen } \\
\text { (mg/L) }\end{array}$ & $\begin{array}{c}\text { pH, field } \\
\text { (standard } \\
\text { units) }\end{array}$ & $\begin{array}{c}\text { Specific } \\
\text { conductance } \\
(\mu \mathrm{S} / \mathrm{cm})\end{array}$ & $\begin{array}{c}\text { Water } \\
\text { temperature } \\
\left({ }^{\circ} \mathrm{C}\right)\end{array}$ & $\begin{array}{l}\text { Turbdity, } \\
\text { detection } \\
\text { angle } 90+/-30 \\
\text { degrees } \\
\text { (NTU) }\end{array}$ & $\begin{array}{l}\text { Turbidity, detectors } \\
\text { at multiple angles } \\
\text { including } \\
90+/-30 \text { degrees, } \\
\text { radiometric correction } \\
\text { (NTRU) }\end{array}$ & $\begin{array}{c}\text { Oxidation- } \\
\text { reduction (redox) } \\
\text { potential } \\
\text { (mV relative to the } \\
\text { standard hydrogen } \\
\text { electrode) }\end{array}$ & $\begin{array}{c}\text { Dissolved } \\
\text { solids } \\
\text { (mg/L) }\end{array}$ & $\begin{array}{c}\text { Hardness } \\
\text { as } \mathrm{CaCO}_{3} \\
(\mathrm{mg} / \mathrm{L})\end{array}$ & $\begin{array}{l}\text { Suspended } \\
\text { solids } \\
\text { (mg/L) }\end{array}$ & $\begin{array}{c}\text { Alkalinity } \\
\text { as } \mathrm{CaCO}_{3} \\
\text { (mg/L) }\end{array}$ \\
\hline \multicolumn{13}{|c|}{ IW-09 shallow } \\
\hline $3 / 19 / 2002$ & 1100 & 1.4 & 6.9 & 558 & 15.2 & -- & $<0.1$ & 530 & -- & -- & -- & -- \\
\hline $3 / 19 / 2002$ & 1101 & -- & -- & -- & -- & 0.2 & -- & -- & 392 & 220 & $<4$ & 143 \\
\hline $6 / 20 / 2002$ & 0935 & 1.5 & 7.0 & 595 & 15.8 & -- & 0.3 & 370 & -- & -- & -- & -- \\
\hline $6 / 20 / 2002$ & 0936 & -- & -- & -- & -- & 0.2 & -- & -- & 374 & 210 & 4 & 144 \\
\hline $6 / 20 / 2002$ & 0940 & -- & -- & -- & -- & -- & -- & -- & -- & -- & -- & -- \\
\hline $2 / 14 / 2003$ & 1035 & 1.5 & 6.9 & 571 & 15.6 & -- & $<0.1$ & 600 & -- & -- & -- & -- \\
\hline $2 / 14 / 2003$ & 1036 & -- & -- & -- & -- & 0.2 & -- & -- & 380 & 210 & $<4$ & 131 \\
\hline $2 / 14 / 2003$ & 1037 & -- & -- & -- & -- & -- & -- & -- & -- & -- & -- & -- \\
\hline $6 / 25 / 2003$ & 0855 & 0.3 & 7.0 & 579 & 16.1 & -- & 0.3 & 560 & -- & -- & -- & -- \\
\hline $6 / 25 / 2003$ & 0856 & -- & -- & -- & -- & 0.4 & -- & -- & 382 & 230 & $<4$ & 121 \\
\hline $6 / 25 / 2003$ & 0900 & 0.3 & 7.0 & 579 & 16.1 & -- & 0.3 & 560 & -- & -- & -- & -- \\
\hline $6 / 25 / 2003$ & 0905 & 0.3 & 7.0 & 579 & 16.1 & -- & 0.3 & 560 & 392 & 230 & -- & -- \\
\hline $6 / 25 / 2003$ & 0906 & -- & -- & -- & -- & -- & 1.0 & -- & -- & -- & -- & -- \\
\hline $2 / 10 / 2004$ & 1030 & 1.1 & 7.0 & 563 & 15.3 & -- & 0.3 & 320 & -- & -- & -- & -- \\
\hline $2 / 10 / 2004$ & 1031 & -- & -- & -- & -- & 0.3 & -- & -- & 366 & 210 & $<4$ & 126 \\
\hline $6 / 25 / 2004$ & 0925 & 0.6 & 7.0 & 563 & 15.5 & -- & 0.6 & 410 & -- & -- & -- & -- \\
\hline $6 / 25 / 2004$ & 0926 & -- & -- & -- & -- & 1.0 & -- & -- & 372 & 220 & $<4$ & 118 \\
\hline $7 / 11 / 2005$ & 1200 & 0.3 & 7.0 & 546 & 15.9 & -- & 2.4 & 330 & -- & -- & -- & -- \\
\hline $7 / 11 / 2005$ & 1201 & -- & -- & -- & -- & 0.5 & -- & -- & 362 & 220 & $<4$ & 110 \\
\hline $6 / 14 / 2006$ & 1045 & 1.8 & 6.6 & 566 & 15.7 & -- & 1.4 & 400 & -- & -- & -- & -- \\
\hline $6 / 14 / 2006$ & 1046 & -- & -- & -- & -- & 1.8 & -- & -- & 379 & 210 & $<4$ & 129 \\
\hline $6 / 14 / 2006$ & 1050 & 1.8 & 6.6 & 566 & 15.7 & -- & 1.4 & 400 & 385 & 200 & -- & -- \\
\hline $6 / 14 / 2006$ & 1051 & -- & -- & -- & -- & -- & 2.6 & -- & -- & -- & -- & -- \\
\hline $6 / 20 / 2007$ & 1020 & 0.4 & 6.9 & 524 & 16.0 & -- & 4.5 & 480 & -- & -- & -- & -- \\
\hline $6 / 20 / 2007$ & 1021 & -- & -- & -- & -- & 0.4 & -- & -- & 353 & 200 & $<10$ & 116 \\
\hline $6 / 20 / 2007$ & 1025 & 0.4 & 6.9 & 524 & 16.0 & -- & 4.5 & 480 & -- & -- & -- & -- \\
\hline $6 / 12 / 2008$ & 0940 & 0.8 & 6.7 & 512 & 15.7 & -- & 0.9 & 410 & -- & -- & -- & -- \\
\hline $6 / 12 / 2008$ & 0941 & -- & -- & -- & -- & 0.2 & -- & -- & 337 & 190 & $<4$ & 117 \\
\hline $2 / 10 / 2009$ & 0955 & 0.4 & 6.7 & 486 & 15.4 & -- & 0.3 & 390 & -- & -- & -- & -- \\
\hline $2 / 10 / 2009$ & 0956 & -- & -- & -- & -- & $<0.1$ & -- & -- & 314 & 190 & $<4$ & 108 \\
\hline $4 / 2 / 2009$ & 1055 & 0.5 & 6.7 & 479 & 14.8 & -- & 0.7 & 510 & -- & -- & -- & -- \\
\hline $4 / 2 / 2009$ & 1056 & -- & -- & -- & -- & 0.8 & -- & -- & 289 & 180 & $<4$ & 102 \\
\hline
\end{tabular}


$\left[\mathrm{mg} / \mathrm{L}\right.$, milligrams per liter; $\mu \mathrm{S} / \mathrm{cm}$, microsiemens per centimeter at 25 degrees Celsius; ${ }^{\circ} \mathrm{C}$, degrees Celsius; +/-, plus or minus; NTU, nephelometric turbidity units; NTRU, nephelometric turbidity ratiometric units; $\mathrm{mV}$, millivolts; $\mathrm{CaCO}_{3}$, calcium carbonate; --, not determined or not applicable; <, less than; $\mathrm{M}^{*}$, presence of material verified, but not quantified; $\mathrm{E}^{* *}$, estimated]

\begin{tabular}{|c|c|c|c|c|c|c|c|c|c|c|c|c|}
\hline $\begin{array}{l}\text { Date of } \\
\text { sample } \\
\text { collection } \\
\text { (month/day/ } \\
\text { year) }\end{array}$ & $\begin{array}{c}\text { Sample } \\
\text { start } \\
\text { time }\end{array}$ & $\begin{array}{l}\text { Dissolved } \\
\text { oxygen } \\
\text { (mg/L) }\end{array}$ & $\begin{array}{l}\text { pH, field } \\
\text { (standard } \\
\text { units) }\end{array}$ & $\begin{array}{c}\text { Specific } \\
\text { conductance } \\
(\mu \mathrm{S} / \mathrm{cm})\end{array}$ & $\begin{array}{c}\text { Water } \\
\text { temperature } \\
\left({ }^{\circ} \mathrm{C}\right)\end{array}$ & $\begin{array}{l}\text { Turbdity, } \\
\text { detection } \\
\text { angle } 90+/-30 \\
\text { degrees } \\
\text { (NTU) }\end{array}$ & $\begin{array}{c}\text { Turbidity, detectors } \\
\text { at multiple angles } \\
\text { including } \\
90+/-30 \text { degrees, } \\
\text { radiometric correction } \\
\text { (NTRU) }\end{array}$ & $\begin{array}{c}\text { Oxidation- } \\
\text { reduction (redox) } \\
\text { potential } \\
\text { (mV relative to the } \\
\text { standard hydrogen } \\
\text { electrode) }\end{array}$ & $\begin{array}{l}\text { Dissolved } \\
\text { solids } \\
\text { (mg/L) }\end{array}$ & $\begin{array}{c}\text { Hardness } \\
\text { as } \mathrm{CaCO}_{3} \\
(\mathrm{mg} / \mathrm{L})\end{array}$ & $\begin{array}{l}\text { Suspended } \\
\text { solids } \\
\text { (mg/L) }\end{array}$ & $\begin{array}{c}\text { Alkalinity } \\
\text { as } \mathrm{CaCO}_{3} \\
\text { (mg/L) }\end{array}$ \\
\hline \multicolumn{13}{|c|}{ IW-09 shallow-Continued } \\
\hline $4 / 2 / 2009$ & 1100 & 0.5 & 6.7 & 479 & 14.8 & -- & 0.7 & 510 & -- & -- & -- & -- \\
\hline $4 / 22 / 2009$ & 1020 & 0.4 & 6.9 & 482 & 15.7 & -- & 0.9 & 360 & -- & -- & -- & -- \\
\hline $4 / 22 / 2009$ & 1021 & -- & -- & -- & -- & 0.4 & -- & -- & 297 & 180 & $<4$ & 107 \\
\hline $6 / 10 / 2009$ & 0955 & 0.2 & 6.7 & 482 & 16.0 & -- & 1.2 & 320 & -- & -- & -- & -- \\
\hline $6 / 10 / 2009$ & 0956 & -- & -- & -- & -- & 0.3 & -- & -- & 306 & 190 & $<4$ & 104 \\
\hline $6 / 10 / 2009$ & 1000 & 0.2 & 6.7 & 482 & 16.0 & -- & 1.2 & 320 & 330 & 180 & -- & -- \\
\hline $6 / 10 / 2009$ & 1001 & -- & -- & -- & -- & -- & -- & -- & -- & -- & -- & -- \\
\hline $7 / 14 / 2009$ & 1020 & -- & 7.1 & 488 & 15.8 & -- & 0.6 & 390 & -- & -- & -- & -- \\
\hline $7 / 14 / 2009$ & 1021 & -- & -- & -- & -- & 0.3 & -- & -- & 300 & 200 & $<4$ & 102 \\
\hline $7 / 14 / 2009$ & 1025 & -- & 7.1 & 488 & 15.8 & -- & 0.6 & 390 & -- & -- & -- & -- \\
\hline $8 / 19 / 2009$ & 1000 & 0.2 & 7.1 & 483 & 15.4 & -- & 0.6 & 360 & -- & -- & -- & -- \\
\hline $8 / 19 / 2009$ & 1001 & -- & -- & -- & -- & 0.1 & -- & -- & 317 & 190 & $<4$ & 102 \\
\hline $8 / 19 / 2009$ & 1005 & 0.2 & 7.1 & 483 & 15.4 & -- & 0.6 & 360 & -- & -- & -- & -- \\
\hline $11 / 17 / 2009$ & 1005 & 0.5 & 7.1 & 491 & 15.4 & -- & 0.7 & 250 & -- & -- & -- & -- \\
\hline $11 / 17 / 2009$ & 1006 & -- & -- & -- & -- & 0.2 & -- & -- & 310 & 190 & $<4$ & 109 \\
\hline $11 / 17 / 2009$ & 1010 & 0.5 & 7.1 & 491 & 15.4 & -- & 0.7 & 250 & -- & -- & -- & -- \\
\hline 3/9/2010 & 1010 & 0.7 & 7.1 & 496 & 15.8 & -- & 1.0 & 340 & -- & -- & -- & -- \\
\hline $3 / 9 / 2010$ & 1011 & -- & -- & -- & -- & 0.2 & -- & -- & 307 & 180 & $<10$ & 113 \\
\hline $3 / 9 / 2010$ & 1015 & 0.7 & 7.1 & 496 & 15.8 & -- & 1.0 & 340 & -- & -- & -- & -- \\
\hline \multicolumn{13}{|c|}{ IW-09 deep } \\
\hline $3 / 19 / 2002$ & 1305 & 0.2 & 7.2 & 404 & 15.7 & -- & 5.2 & 190 & -- & -- & -- & -- \\
\hline $3 / 19 / 2002$ & 1306 & -- & -- & -- & -- & 23.0 & -- & -- & 299 & 180 & 28 & 194 \\
\hline $6 / 24 / 2002$ & 1045 & 0.2 & 7.6 & 516 & 16.0 & -- & 1.1 & 180 & -- & -- & -- & -- \\
\hline $6 / 24 / 2002$ & 1046 & -- & -- & -- & -- & 27.0 & -- & -- & 294 & 190 & 40 & 197 \\
\hline $2 / 14 / 2003$ & 1335 & 0.2 & 7.3 & 513 & 16.0 & -- & 15.0 & 150 & -- & -- & -- & -- \\
\hline $2 / 14 / 2003$ & 1336 & -- & -- & -- & -- & 13.0 & -- & -- & 292 & 190 & 10 & 195 \\
\hline $6 / 25 / 2003$ & 1135 & $\mathrm{M}$ & 7.3 & 488 & 16.2 & -- & 2.5 & 190 & -- & -- & -- & -- \\
\hline $6 / 25 / 2003$ & 1136 & -- & -- & -- & -- & 2.5 & -- & -- & 306 & 180 & 4 & 196 \\
\hline $6 / 25 / 2003$ & 1140 & M & 7.3 & 488 & 16.2 & -- & 2.5 & 190 & -- & -- & -- & -- \\
\hline $6 / 25 / 2003$ & 1145 & $\mathrm{M}$ & 7.3 & 488 & 16.2 & -- & 2.5 & 190 & 312 & 180 & -- & -- \\
\hline $6 / 25 / 2003$ & 1146 & -- & -- & -- & -- & -- & 5.0 & -- & -- & -- & -- & -- \\
\hline $2 / 10 / 2004$ & 1225 & 0.1 & 7.3 & 575 & 15.9 & -- & 6.0 & 160 & -- & -- & -- & -- \\
\hline
\end{tabular}


Table 5. Summary of physical property data from water samples collected as part of the Equus Beds Experimental Passive Recharge Project at RB1, 2009-2010.—Continued [mg/L, milligrams per liter; $\mu \mathrm{S} / \mathrm{cm}$, microsiemens per centimeter at 25 degrees Celsius; ${ }^{\circ} \mathrm{C}$, degrees Celsius; +/-, plus or minus; NTU, nephelometric turbidity units; NTRU, nephelometric turbidity ratiometric units; $\mathrm{mV}$, millivolts; $\mathrm{CaCO}_{3}$, calcium carbonate; --, not determined or not applicable; <, less than; $\mathrm{M}^{*}$, presence of material verified, but not quantified; $\mathrm{E}^{* *}$, estimated]

\begin{tabular}{|c|c|c|c|c|c|c|c|c|c|c|c|c|}
\hline $\begin{array}{c}\text { Date of } \\
\text { sample } \\
\text { collection } \\
\text { (month/day/ } \\
\text { year) }\end{array}$ & $\begin{array}{c}\text { Sample } \\
\text { start } \\
\text { time }\end{array}$ & $\begin{array}{c}\text { Dissolved } \\
\text { oxygen } \\
\text { (mg/L) }\end{array}$ & $\begin{array}{c}\text { pH, field } \\
\text { (standard } \\
\text { units) }\end{array}$ & $\begin{array}{c}\text { Specific } \\
\text { conductance } \\
\text { ( } \mathrm{S} / \mathrm{cm})\end{array}$ & $\begin{array}{c}\text { Water } \\
\text { temperature } \\
\left({ }^{\circ} \mathrm{C}\right)\end{array}$ & $\begin{array}{l}\text { Turbdity, } \\
\text { detection } \\
\text { angle } 90+/-30 \\
\text { degrees } \\
\text { (NTU) }\end{array}$ & $\begin{array}{l}\text { Turbidity, detectors } \\
\text { at multiple angles } \\
\text { including } \\
90+/-30 \text { degrees, } \\
\text { radiometric correction } \\
\text { (NTRU) }\end{array}$ & $\begin{array}{c}\text { Oxidation- } \\
\text { reduction (redox) } \\
\text { potential } \\
\text { (mV relative to the } \\
\text { standard hydrogen } \\
\text { electrode) }\end{array}$ & $\begin{array}{l}\text { Dissolved } \\
\text { solids } \\
\text { (mg/L) }\end{array}$ & $\begin{array}{c}\text { Hardness } \\
\text { as } \mathrm{CaCO}_{3} \\
(\mathrm{mg} / \mathrm{L})\end{array}$ & $\begin{array}{l}\text { Suspended } \\
\text { solids } \\
\text { (mg/L) }\end{array}$ & $\begin{array}{c}\text { Alkalinity } \\
\text { as } \mathrm{CaCO}_{3} \\
\text { (mg/L) }\end{array}$ \\
\hline \multicolumn{13}{|c|}{ IW-09 deep-Continued } \\
\hline $2 / 10 / 2004$ & 1226 & -- & -- & -- & -- & 2.9 & -- & -- & 336 & 210 & 6 & 196 \\
\hline $2 / 10 / 2004$ & 1227 & -- & -- & -- & -- & -- & -- & -- & -- & -- & -- & -- \\
\hline $6 / 25 / 2004$ & 1130 & -- & 7.4 & 552 & 16.1 & -- & 4.2 & 140 & -- & -- & -- & -- \\
\hline $6 / 25 / 2004$ & 1131 & -- & -- & -- & -- & 3.4 & -- & -- & 328 & 210 & 6 & 192 \\
\hline $6 / 25 / 2004$ & 1132 & -- & -- & -- & -- & -- & -- & -- & -- & -- & -- & -- \\
\hline $6 / 25 / 2004$ & 1135 & 0.1 & 7.4 & 552 & 16.1 & -- & 4.2 & 140 & -- & -- & -- & -- \\
\hline $7 / 11 / 2005$ & 1030 & 0.1 & 7.3 & 579 & 16.2 & -- & 2.5 & 120 & -- & -- & -- & -- \\
\hline $7 / 11 / 2005$ & 1031 & -- & -- & -- & -- & 3.6 & -- & -- & 318 & 210 & 13 & 188 \\
\hline $6 / 14 / 2006$ & 1235 & 0.3 & 7.1 & 567 & 16.2 & -- & 1.9 & 240 & -- & -- & -- & -- \\
\hline $6 / 14 / 2006$ & 1236 & -- & -- & -- & -- & 1.3 & -- & -- & 318 & 210 & 8 & 187 \\
\hline $6 / 20 / 2007$ & 1220 & 0.1 & 7.3 & 550 & 16.1 & -- & 3.5 & 140 & -- & -- & -- & -- \\
\hline $6 / 20 / 2007$ & 1221 & -- & -- & -- & -- & 0.6 & -- & -- & 323 & 200 & $<10$ & 194 \\
\hline $6 / 20 / 2007$ & 1225 & 0.1 & 7.3 & 550 & 16.1 & -- & 3.5 & 140 & -- & -- & -- & -- \\
\hline $6 / 12 / 2008$ & 1110 & 0.1 & 7.0 & 593 & 16.0 & -- & 4.4 & 160 & -- & -- & -- & -- \\
\hline $6 / 12 / 2008$ & 1111 & -- & -- & -- & -- & 1.6 & -- & -- & 339 & 210 & 5 & 194 \\
\hline $2 / 10 / 2009$ & 1125 & 0.1 & 7.1 & 598 & 15.7 & -- & 9.2 & 200 & -- & -- & -- & -- \\
\hline $2 / 10 / 2009$ & 1126 & -- & -- & -- & -- & 3.7 & -- & -- & 350 & 220 & 9 & 191 \\
\hline $4 / 2 / 2009$ & 1215 & 0.1 & 7.0 & 600 & 15.5 & -- & 13.0 & 190 & -- & -- & -- & -- \\
\hline $4 / 2 / 2009$ & 1216 & -- & -- & -- & -- & 6.2 & -- & -- & 323 & 230 & 9 & 190 \\
\hline $4 / 2 / 2009$ & 1220 & 0.1 & 7.0 & 600 & 15.5 & -- & 13.0 & 190 & -- & -- & -- & -- \\
\hline $4 / 22 / 2009$ & 1200 & 0.1 & 7.2 & 603 & 15.9 & -- & 8.0 & 180 & -- & -- & -- & -- \\
\hline $4 / 22 / 2009$ & 1201 & -- & -- & -- & -- & 1.3 & -- & -- & 340 & 220 & 6 & 188 \\
\hline $6 / 10 / 2009$ & 1120 & 0.2 & 7.1 & 604 & 16.2 & -- & 4.2 & 210 & -- & -- & -- & -- \\
\hline $6 / 10 / 2009$ & 1121 & -- & -- & -- & -- & 2.1 & -- & -- & 342 & 220 & $<4$ & 188 \\
\hline $6 / 10 / 2009$ & 1125 & 0.2 & 7.1 & 604 & 16.2 & -- & 4.2 & 210 & 347 & 210 & -- & -- \\
\hline $6 / 10 / 2009$ & 1126 & -- & -- & -- & -- & -- & E3.5 & -- & -- & -- & -- & -- \\
\hline $7 / 14 / 2009$ & 1150 & 0.6 & 7.3 & 613 & 16.0 & -- & 3.3 & 210 & -- & -- & -- & -- \\
\hline $7 / 14 / 2009$ & 1151 & -- & -- & -- & -- & 1.1 & -- & -- & 332 & 230 & $<4$ & 188 \\
\hline $7 / 14 / 2009$ & 1155 & 0.6 & 7.3 & 613 & 16.0 & -- & 3.3 & 210 & -- & -- & -- & -- \\
\hline $8 / 19 / 2009$ & 1150 & 0.2 & 7.3 & 652 & 16.2 & -- & 7.5 & 180 & -- & -- & -- & -- \\
\hline $8 / 19 / 2009$ & 1151 & -- & -- & -- & -- & 2.2 & -- & -- & 363 & 230 & 6 & 188 \\
\hline $8 / 19 / 2009$ & 1155 & 0.2 & 7.3 & 652 & 16.2 & -- & 7.5 & 180 & -- & -- & -- & -- \\
\hline
\end{tabular}


$\left[\mathrm{mg} / \mathrm{L}\right.$, milligrams per liter; $\mu \mathrm{S} / \mathrm{cm}$, microsiemens per centimeter at 25 degrees Celsius; ${ }^{\circ} \mathrm{C}$, degrees Celsius; $+/-$, plus or minus; NTU, nephelometric turbidity units; NTRU, nephelometric turbidity ratiometric units; $\mathrm{mV}$, millivolts; $\mathrm{CaCO}_{3}$, calcium carbonate; --, not determined or not applicable; <, less than; $\mathrm{M}^{*}$, presence of material verified, but not quantified; $\mathrm{E}^{* *}$, estimated]

\begin{tabular}{|c|c|c|c|c|c|c|c|c|c|c|c|c|}
\hline $\begin{array}{c}\text { Date of } \\
\text { sample } \\
\text { collection } \\
\text { (month/day/ } \\
\text { year) }\end{array}$ & $\begin{array}{c}\text { Sample } \\
\text { start } \\
\text { time }\end{array}$ & $\begin{array}{l}\text { Dissolved } \\
\text { oxygen } \\
\text { (mg/L) }\end{array}$ & $\begin{array}{l}\text { pH, field } \\
\text { (standard } \\
\text { units) }\end{array}$ & $\begin{array}{c}\text { Specific } \\
\text { conductance } \\
(\mu \mathrm{S} / \mathrm{cm})\end{array}$ & $\begin{array}{c}\text { Water } \\
\text { temperature } \\
\left({ }^{\circ} \mathrm{C}\right)\end{array}$ & $\begin{array}{c}\text { Turbdity, } \\
\text { detection } \\
\text { angle } 90+/-30 \\
\text { degrees } \\
\text { (NTU) }\end{array}$ & $\begin{array}{l}\text { Turbidity, detectors } \\
\text { at multiple angles } \\
\text { including } \\
90+/-30 \text { degrees, } \\
\text { radiometric correction } \\
\text { (NTRU) }\end{array}$ & $\begin{array}{c}\text { Oxidation- } \\
\text { reduction (redox) } \\
\text { potential } \\
\text { (mV relative to the } \\
\text { standard hydrogen } \\
\text { electrode) }\end{array}$ & $\begin{array}{l}\text { Dissolved } \\
\text { solids } \\
\text { (mg/L) }\end{array}$ & $\begin{array}{c}\text { Hardness } \\
\text { as } \mathrm{CaCO}_{3} \\
(\mathrm{mg} / \mathrm{L})\end{array}$ & $\begin{array}{l}\text { Suspended } \\
\text { solids } \\
\text { (mg/L) }\end{array}$ & $\begin{array}{c}\text { Alkalinity } \\
\text { as } \mathrm{CaCO}_{3} \\
\text { (mg/L) }\end{array}$ \\
\hline \multicolumn{13}{|c|}{ IW-09 deep-Continued } \\
\hline $11 / 17 / 2009$ & 1145 & 0.2 & 7.5 & 606 & 16.0 & -- & 1.3 & 220 & -- & -- & -- & -- \\
\hline $11 / 17 / 2009$ & 1146 & -- & -- & -- & -- & 0.5 & -- & -- & 343 & 230 & $<4$ & 188 \\
\hline $11 / 17 / 2009$ & 1150 & 0.2 & 7.5 & 606 & 16.0 & -- & 1.3 & 220 & -- & -- & -- & -- \\
\hline 3/9/2010 & 1155 & 0.2 & 7.3 & 647 & 16.1 & -- & 1.2 & 170 & -- & -- & -- & -- \\
\hline $3 / 9 / 2010$ & 1156 & -- & -- & -- & -- & 0.6 & -- & -- & 359 & 240 & $<10$ & 113 \\
\hline $3 / 9 / 2010$ & 1200 & 0.2 & 7.3 & 647 & 16.1 & -- & 1.2 & 170 & -- & -- & -- & -- \\
\hline \multicolumn{13}{|c|}{ RB1 source water } \\
\hline $8 / 3 / 2007$ & 1105 & 6.6 & 7.2 & 420 & 26.1 & -- & 6.8 & 300 & -- & -- & -- & -- \\
\hline $8 / 3 / 2007$ & 1106 & -- & -- & -- & -- & -- & -- & -- & 263 & 76 & 6 & 90 \\
\hline $8 / 3 / 2007$ & 1107 & -- & -- & -- & -- & -- & -- & -- & -- & -- & -- & -- \\
\hline $8 / 3 / 2007$ & 1110 & 6.6 & 7.2 & 420 & 26.1 & -- & 6.8 & 300 & -- & -- & -- & -- \\
\hline $8 / 3 / 2007$ & 1115 & 6.6 & 7.2 & 420 & 26.1 & -- & 6.8 & 300 & -- & -- & -- & -- \\
\hline $8 / 3 / 2007$ & 1116 & -- & -- & -- & -- & -- & -- & -- & 245 & 76 & 6 & 64 \\
\hline $8 / 3 / 2007$ & 1120 & 6.6 & 7.2 & 420 & 26.1 & -- & 6.8 & 300 & -- & -- & -- & -- \\
\hline $4 / 3 / 2009$ & 1215 & 9.8 & 5.9 & 515 & 9.3 & -- & 5.7 & 490 & -- & -- & -- & -- \\
\hline $4 / 3 / 2009$ & 1216 & -- & -- & -- & -- & -- & -- & -- & 311 & 160 & $<4$ & 36 \\
\hline 4/3/2009 & 1220 & 9.8 & 5.9 & 515 & 9.3 & -- & 5.7 & 490 & -- & -- & -- & -- \\
\hline $4 / 14 / 2009$ & 1140 & 10.7 & 7.7 & 657 & 10.3 & -- & 8.4 & 510 & -- & -- & -- & -- \\
\hline $4 / 14 / 2009$ & 1141 & -- & -- & -- & -- & -- & -- & -- & 408 & 150 & 8 & 98 \\
\hline 4/17/2009 & 1110 & 9.4 & 6.9 & 791 & 14.6 & -- & 2.3 & 400 & -- & -- & -- & -- \\
\hline $4 / 17 / 2009$ & 1111 & -- & -- & -- & -- & -- & -- & -- & 493 & 230 & $<4$ & 114 \\
\hline \multicolumn{13}{|c|}{ RB1-MN shallow } \\
\hline $8 / 30 / 2006$ & 1010 & 0.2 & 6.8 & 1,060 & 15.8 & -- & 1.8 & 140 & -- & -- & -- & -- \\
\hline $8 / 30 / 2006$ & 1011 & -- & -- & -- & -- & -- & -- & -- & 626 & 360 & 6 & 202 \\
\hline $8 / 30 / 2006$ & 1015 & 0.2 & 6.8 & 1,060 & 15.8 & -- & 1.8 & 140 & -- & -- & -- & -- \\
\hline $11 / 29 / 2006$ & 1100 & 0.2 & 6.9 & 1,050 & 14.7 & -- & 1.5 & 120 & -- & -- & -- & -- \\
\hline $11 / 29 / 2006$ & 1101 & -- & -- & -- & -- & -- & -- & -- & 595 & 360 & $<4$ & 204 \\
\hline $2 / 23 / 2007$ & 1010 & 0.1 & 6.9 & 1,040 & 15.4 & -- & 1.3 & 110 & -- & -- & -- & -- \\
\hline $2 / 23 / 2007$ & 1011 & -- & -- & -- & -- & -- & -- & -- & 611 & 350 & 7 & 204 \\
\hline $6 / 4 / 2007$ & 1015 & M & 7.0 & 1,040 & 15.8 & -- & 2.4 & 140 & -- & -- & -- & -- \\
\hline $6 / 4 / 2007$ & 1016 & -- & -- & -- & -- & -- & -- & -- & 653 & 350 & $<10$ & 203 \\
\hline $6 / 4 / 2007$ & 1017 & -- & -- & -- & -- & -- & -- & -- & -- & -- & -- & -- \\
\hline
\end{tabular}


Table 5. Summary of physical property data from water samples collected as part of the Equus Beds Experimental Passive Recharge Project at RB1, 2009-2010.-Continued $\left[\mathrm{mg} / \mathrm{L}\right.$, milligrams per liter; $\mu \mathrm{S} / \mathrm{cm}$, microsiemens per centimeter at 25 degrees Celsius; ${ }^{\circ} \mathrm{C}$, degrees Celsius; $+/$, plus or minus; NTU, nephelometric turbidity units; NTRU, nephelometric turbidity ratiometric units; $\mathrm{mV}$, millivolts; $\mathrm{CaCO}_{3}$, calcium carbonate; --, not determined or not applicable; <, less than; $\mathrm{M}^{*}$, presence of material verified, but not quantified; $\mathrm{E}^{* *}$, estimated]

\begin{tabular}{|c|c|c|c|c|c|c|c|c|c|c|c|c|}
\hline $\begin{array}{c}\text { Date of } \\
\text { sample } \\
\text { collection } \\
\text { (month/day/ } \\
\text { year) }\end{array}$ & $\begin{array}{c}\text { Sample } \\
\text { start } \\
\text { time }\end{array}$ & $\begin{array}{l}\text { Dissolved } \\
\text { oxygen } \\
\text { (mg/L) }\end{array}$ & $\begin{array}{c}\text { pH, field } \\
\text { (standard } \\
\text { units) }\end{array}$ & 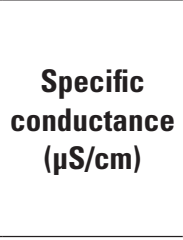 & $\begin{array}{c}\text { Water } \\
\text { temperature } \\
\left({ }^{\circ} \mathrm{C}\right)\end{array}$ & $\begin{array}{c}\text { Turbdity, } \\
\text { detection } \\
\text { angle } 90+/-30 \\
\text { degrees } \\
\text { (NTU) }\end{array}$ & $\begin{array}{l}\text { Turbidity, detectors } \\
\text { at multiple angles } \\
\text { including } \\
90+/-30 \text { degrees, } \\
\text { radiometric correction } \\
\text { (NTRU) }\end{array}$ & $\begin{array}{c}\text { Oxidation- } \\
\text { reduction (redox) } \\
\text { potential } \\
\text { (mV relative to the } \\
\text { standard hydrogen } \\
\text { electrode) }\end{array}$ & $\begin{array}{l}\text { Dissolved } \\
\text { solids } \\
\text { (mg/L) }\end{array}$ & $\begin{array}{c}\text { Hardness } \\
\text { as } \mathrm{CaCO}_{3} \\
(\mathrm{mg} / \mathrm{L})\end{array}$ & $\begin{array}{l}\text { Suspended } \\
\text { solids } \\
\text { (mg/L) }\end{array}$ & $\begin{array}{c}\text { Alkalinity } \\
\text { as } \mathrm{CaCO}_{3} \\
\text { (mg/L) }\end{array}$ \\
\hline \multicolumn{13}{|c|}{ RB1-MN shallow-Continued } \\
\hline $8 / 29 / 2007$ & 1020 & 0.1 & 6.7 & 978 & 15.8 & -- & 0.8 & 110 & -- & -- & -- & -- \\
\hline $8 / 29 / 2007$ & 1021 & -- & -- & -- & -- & -- & -- & -- & 559 & 330 & 4 & 200 \\
\hline $8 / 29 / 2007$ & 1025 & 0.1 & 6.7 & 978 & 15.8 & -- & 0.8 & 110 & -- & -- & -- & -- \\
\hline $8 / 29 / 2007$ & 1030 & 0.1 & 6.7 & 978 & 15.8 & -- & 0.8 & 110 & -- & -- & -- & -- \\
\hline $8 / 29 / 2007$ & 1031 & -- & -- & -- & -- & -- & -- & -- & 579 & 330 & 4 & 204 \\
\hline $8 / 29 / 2007$ & 1035 & 0.1 & 6.7 & 978 & 15.8 & -- & 0.8 & 110 & -- & -- & -- & -- \\
\hline $3 / 5 / 2008$ & 1025 & 0.1 & 7.0 & 1,040 & 15.0 & -- & 0.8 & 130 & -- & -- & -- & -- \\
\hline $3 / 5 / 2008$ & 1026 & -- & -- & -- & -- & -- & -- & -- & 593 & 370 & 4 & 196 \\
\hline $3 / 5 / 2008$ & 1030 & 0.1 & 7.0 & 1,040 & 15.0 & -- & 0.8 & 130 & -- & -- & -- & -- \\
\hline $3 / 5 / 2008$ & 1031 & -- & -- & -- & -- & -- & -- & -- & 599 & 380 & 4 & 196 \\
\hline $8 / 19 / 2008$ & 1010 & 0.1 & 6.8 & 993 & 15.6 & -- & 1.1 & 120 & -- & -- & -- & -- \\
\hline $8 / 19 / 2008$ & 1011 & -- & -- & -- & -- & -- & -- & -- & 591 & 360 & $<4$ & 202 \\
\hline $8 / 19 / 2008$ & 1015 & 0.1 & 6.8 & 993 & 15.6 & -- & 1.1 & 120 & -- & -- & -- & -- \\
\hline 2/9/2009 & 1020 & 0.1 & 6.7 & 1,040 & 15.1 & -- & 0.4 & 160 & -- & -- & -- & -- \\
\hline 2/9/2009 & 1021 & -- & -- & -- & -- & -- & -- & -- & 582 & 380 & $<4$ & 207 \\
\hline $4 / 1 / 2009$ & 1110 & 0.9 & 6.6 & 1,020 & 14.9 & -- & 0.5 & 150 & -- & -- & -- & -- \\
\hline $4 / 1 / 2009$ & 1111 & -- & -- & -- & -- & -- & -- & -- & 582 & 380 & 6 & 201 \\
\hline $4 / 1 / 2009$ & 1115 & 0.9 & 6.6 & 1,020 & 14.9 & -- & 0.5 & 150 & -- & -- & -- & -- \\
\hline $4 / 21 / 2009$ & 0955 & 0.2 & 6.8 & 1,060 & 15.2 & -- & 0.6 & 140 & -- & -- & -- & -- \\
\hline $4 / 21 / 2009$ & 0956 & -- & -- & -- & -- & -- & -- & -- & 332 & 380 & 9 & 200 \\
\hline $6 / 25 / 2009$ & 1000 & 0.2 & 6.7 & 1,050 & 16.6 & -- & 0.3 & 150 & -- & -- & -- & -- \\
\hline $6 / 25 / 2009$ & 1001 & -- & -- & -- & -- & -- & -- & -- & 635 & 380 & 8 & 200 \\
\hline $6 / 25 / 2009$ & 1005 & 0.2 & 6.7 & 1,050 & 16.6 & -- & 0.3 & 150 & -- & -- & -- & -- \\
\hline $6 / 25 / 2009$ & 1010 & 0.2 & 6.7 & 1,050 & 16.6 & -- & 0.3 & 150 & -- & -- & -- & -- \\
\hline $7 / 14 / 2009$ & 1025 & 0.4 & 6.5 & 1,010 & 16.7 & -- & 0.6 & 190 & -- & -- & -- & -- \\
\hline $7 / 14 / 2009$ & 1026 & -- & -- & -- & -- & -- & -- & -- & 570 & 360 & 5 & 204 \\
\hline $7 / 14 / 2009$ & 1030 & 0.4 & 6.5 & 1,010 & 16.7 & -- & 0.6 & 190 & -- & -- & -- & -- \\
\hline $8 / 19 / 2009$ & 0955 & 0.1 & 6.8 & 997 & 16.0 & -- & 0.6 & 170 & -- & -- & -- & -- \\
\hline $8 / 19 / 2009$ & 0956 & -- & -- & -- & -- & -- & -- & -- & 588 & 360 & 7 & 202 \\
\hline $8 / 19 / 2009$ & 0957 & -- & -- & -- & -- & -- & -- & -- & -- & -- & -- & -- \\
\hline $8 / 19 / 2009$ & 1000 & 0.1 & 6.8 & 997 & 16.0 & -- & 0.6 & 170 & -- & -- & -- & -- \\
\hline $11 / 18 / 2009$ & 1000 & 0.4 & 7.0 & 1,070 & 15.4 & -- & 0.2 & 190 & -- & -- & -- & -- \\
\hline
\end{tabular}


$\left[\mathrm{mg} / \mathrm{L}\right.$, milligrams per liter; $\mu \mathrm{S} / \mathrm{cm}$, microsiemens per centimeter at 25 degrees Celsius; ${ }^{\circ} \mathrm{C}$, degrees Celsius; +/-, plus or minus; NTU, nephelometric turbidity units; NTRU, nephelometric turbidity ratiometric units; $\mathrm{mV}$, millivolts; $\mathrm{CaCO}_{3}$, calcium carbonate; --, not determined or not applicable; <, less than; $\mathrm{M}^{*}$, presence of material verified, but not quantified; $\mathrm{E}^{* *}$, estimated]

\begin{tabular}{|c|c|c|c|c|c|c|c|c|c|c|c|c|}
\hline $\begin{array}{c}\text { Date of } \\
\text { sample } \\
\text { collection } \\
\text { (month/day/ } \\
\text { year) }\end{array}$ & $\begin{array}{c}\text { Sample } \\
\text { start } \\
\text { time }\end{array}$ & $\begin{array}{c}\text { Dissolved } \\
\text { oxygen } \\
\text { (mg/L) }\end{array}$ & $\begin{array}{c}\text { pH, field } \\
\text { (standard } \\
\text { units) }\end{array}$ & 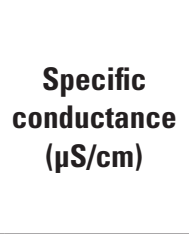 & $\begin{array}{c}\text { Water } \\
\text { temperature } \\
\left({ }^{\circ} \mathrm{C}\right)\end{array}$ & $\begin{array}{l}\text { Turbdity, } \\
\text { detection } \\
\text { angle } 90+/-30 \\
\text { degrees } \\
\text { (NTU) }\end{array}$ & $\begin{array}{l}\text { Turbidity, detectors } \\
\text { at multiple angles } \\
\text { including } \\
90+/-30 \text { degrees, } \\
\text { radiometric correction } \\
\text { (NTRU) }\end{array}$ & $\begin{array}{c}\text { Oxidation- } \\
\text { reduction (redox) } \\
\text { potential } \\
\text { (mV relative to the } \\
\text { standard hydrogen } \\
\text { electrode) }\end{array}$ & $\begin{array}{l}\text { Dissolved } \\
\text { solids } \\
\text { (mg/L) }\end{array}$ & $\begin{array}{l}\text { Hardness } \\
\text { as } \mathrm{CaCO}_{3} \\
(\mathrm{mg} / \mathrm{L})\end{array}$ & $\begin{array}{l}\text { Suspended } \\
\text { solids } \\
\text { (mg/L) }\end{array}$ & $\begin{array}{c}\text { Alkalinity } \\
\text { as } \mathrm{CaCO}_{3} \\
\text { (mg/L) }\end{array}$ \\
\hline \multicolumn{13}{|c|}{ RB1-MN shallow-Continued } \\
\hline $11 / 18 / 2009$ & 1001 & -- & -- & -- & -- & -- & -- & -- & 610 & 390 & 5 & 203 \\
\hline $11 / 18 / 2009$ & 1005 & 0.4 & 7.0 & 1,070 & 15.4 & -- & 0.2 & 190 & -- & -- & -- & -- \\
\hline $3 / 8 / 2010$ & 1005 & 0.4 & 6.9 & 1,050 & 15.2 & -- & 0.5 & -- & -- & -- & -- & -- \\
\hline $3 / 8 / 2010$ & 1006 & -- & -- & -- & -- & -- & -- & -- & 593 & 370 & $<10$ & 212 \\
\hline $3 / 8 / 2010$ & 1010 & 0.4 & 6.9 & 1,050 & 15.2 & -- & 0.5 & -- & -- & -- & -- & -- \\
\hline \multicolumn{13}{|c|}{ RB1-MN deep } \\
\hline $8 / 30 / 2006$ & 1155 & 0.1 & 7.1 & 596 & 16.0 & -- & 0.3 & 120 & -- & -- & -- & -- \\
\hline $8 / 30 / 2006$ & 1156 & -- & -- & -- & -- & -- & -- & -- & 339 & 210 & $<4$ & 203 \\
\hline $8 / 30 / 2006$ & 1200 & 0.1 & 7.1 & 596 & 16.0 & -- & 0.3 & 120 & -- & -- & -- & -- \\
\hline $11 / 29 / 2006$ & 0955 & 0.1 & 7.3 & 623 & 15.0 & -- & 0.1 & 110 & -- & -- & -- & -- \\
\hline $11 / 29 / 2006$ & 0956 & -- & -- & -- & -- & -- & -- & -- & 365 & 220 & $<4$ & 206 \\
\hline $2 / 23 / 2007$ & 1205 & 0.1 & 7.3 & 565 & 15.7 & -- & 0.6 & 100 & -- & -- & -- & -- \\
\hline $2 / 23 / 2007$ & 1206 & -- & -- & -- & -- & -- & -- & -- & 319 & 200 & $<4$ & 204 \\
\hline $6 / 4 / 2007$ & 1140 & 0.1 & 7.5 & 563 & 16.0 & -- & 0.5 & 110 & -- & -- & -- & -- \\
\hline $6 / 4 / 2007$ & 1141 & -- & -- & -- & -- & -- & -- & -- & 341 & 190 & $<10$ & 204 \\
\hline $6 / 4 / 2007$ & 1145 & 0.1 & 7.5 & 563 & 16.0 & -- & 0.5 & 110 & -- & -- & -- & -- \\
\hline $6 / 4 / 2007$ & 1146 & -- & -- & -- & -- & -- & -- & -- & 338 & 190 & $<10$ & 202 \\
\hline $8 / 29 / 2007$ & 1230 & 0.1 & 7.1 & 631 & 16.0 & -- & 0.2 & 100 & -- & -- & -- & -- \\
\hline $8 / 29 / 2007$ & 1231 & -- & -- & -- & -- & -- & -- & -- & 324 & 210 & $<4$ & 200 \\
\hline $8 / 29 / 2007$ & 1235 & 0.1 & 7.1 & 631 & 16.0 & -- & 0.2 & 100 & -- & -- & -- & -- \\
\hline $3 / 5 / 2008$ & 1155 & 0.2 & 7.4 & 625 & 15.5 & -- & 0.1 & 110 & -- & -- & -- & -- \\
\hline $3 / 5 / 2008$ & 1156 & -- & -- & -- & -- & -- & -- & -- & 352 & 230 & $<4$ & 194 \\
\hline $8 / 19 / 2008$ & 1150 & M & 7.1 & 642 & 15.8 & -- & 0.6 & 110 & -- & -- & -- & -- \\
\hline $8 / 19 / 2008$ & 1151 & -- & -- & -- & -- & -- & -- & -- & 370 & 230 & $<4$ & 202 \\
\hline $8 / 19 / 2008$ & 1155 & M & 7.1 & 642 & 15.8 & -- & 0.6 & 110 & -- & -- & -- & -- \\
\hline 2/9/2009 & 1150 & 0.1 & 7.0 & 635 & 15.6 & -- & 0.3 & 140 & -- & -- & -- & -- \\
\hline 2/9/2009 & 1151 & -- & -- & -- & -- & -- & -- & -- & 360 & 230 & $<4$ & 201 \\
\hline $4 / 1 / 2009$ & 1240 & 0.1 & 6.9 & 625 & 15.5 & -- & 0.3 & 130 & -- & -- & -- & -- \\
\hline $4 / 1 / 2009$ & 1241 & -- & -- & -- & -- & -- & -- & -- & 346 & 230 & $<4$ & 199 \\
\hline $4 / 1 / 2009$ & 1242 & -- & -- & -- & -- & -- & -- & -- & -- & -- & -- & -- \\
\hline $4 / 1 / 2009$ & 1245 & 0.1 & 6.9 & 625 & 15.5 & -- & 0.3 & 130 & -- & -- & -- & -- \\
\hline $4 / 21 / 2009$ & 1115 & 0.1 & 7.2 & 584 & 15.6 & -- & 0.4 & 120 & -- & -- & -- & -- \\
\hline
\end{tabular}


Table 5. Summary of physical property data from water samples collected as part of the Equus Beds Experimental Passive Recharge Project at RB1, 2009-2010.-Continued $\left[\mathrm{mg} / \mathrm{L}\right.$, milligrams per liter; $\mu \mathrm{S} / \mathrm{cm}$, microsiemens per centimeter at 25 degrees Celsius; ${ }^{\circ} \mathrm{C}$, degrees Celsius; $+/-$, plus or minus; NTU, nephelometric turbidity units; NTRU, nephelometric turbidity ratiometric units; $\mathrm{mV}$, millivolts; $\mathrm{CaCO}_{3}$, calcium carbonate; --, not determined or not applicable; <, less than; $\mathrm{M}^{*}$, presence of material verified, but not quantified; $\mathrm{E}^{* *}$, estimated

\begin{tabular}{|c|c|c|c|c|c|c|c|c|c|c|c|c|}
\hline $\begin{array}{c}\text { Date of } \\
\text { sample } \\
\text { collection } \\
\text { (month/day/ } \\
\text { year) }\end{array}$ & $\begin{array}{c}\text { Sample } \\
\text { start } \\
\text { time }\end{array}$ & $\begin{array}{l}\text { Dissolved } \\
\text { oxygen } \\
\text { (mg/L) }\end{array}$ & $\begin{array}{l}\text { pH, field } \\
\text { (standard } \\
\text { units) }\end{array}$ & $\begin{array}{c}\text { Specific } \\
\text { conductance } \\
\text { ( } \mathrm{SS} / \mathrm{cm})\end{array}$ & $\begin{array}{c}\text { Water } \\
\text { temperature } \\
\left({ }^{\circ} \mathrm{C}\right)\end{array}$ & $\begin{array}{l}\text { Turbdity, } \\
\text { detection } \\
\text { angle } 90+/-30 \\
\text { degrees } \\
\text { (NTU) }\end{array}$ & $\begin{array}{l}\text { Turbidity, detectors } \\
\text { at multiple angles } \\
\text { including } \\
90+/-30 \text { degrees, } \\
\text { radiometric correction } \\
\text { (NTRU) }\end{array}$ & $\begin{array}{c}\text { Oxidation- } \\
\text { reduction (redox) } \\
\text { potential } \\
\text { (mV relative to the } \\
\text { standard hydrogen } \\
\text { electrode) }\end{array}$ & $\begin{array}{l}\text { Dissolved } \\
\text { solids } \\
\text { (mg/L) }\end{array}$ & $\begin{array}{l}\text { Hardness } \\
\text { as } \mathrm{CaCO}_{3} \\
(\mathrm{mg} / \mathrm{L})\end{array}$ & $\begin{array}{l}\text { Suspended } \\
\text { solids } \\
\text { (mg/L) }\end{array}$ & $\begin{array}{c}\text { Alkalinity } \\
\text { as } \mathrm{CaCO}_{3} \\
(\mathrm{mg} / \mathrm{L})\end{array}$ \\
\hline \multicolumn{13}{|c|}{ RB1-MN deep-Continued } \\
\hline $4 / 21 / 2009$ & 1115 & 0.1 & 7.2 & 584 & 15.6 & -- & 0.4 & 120 & -- & -- & -- & -- \\
\hline $4 / 21 / 2009$ & 1116 & -- & -- & -- & -- & -- & -- & -- & 331 & 210 & $<4$ & 202 \\
\hline $6 / 25 / 2009$ & 1200 & 0.1 & 7.1 & 593 & 16.5 & -- & 0.2 & 140 & -- & -- & -- & -- \\
\hline $6 / 25 / 2009$ & 1201 & -- & -- & -- & -- & -- & -- & -- & 347 & 220 & $<4$ & 198 \\
\hline $6 / 25 / 2009$ & 1205 & 0.1 & 7.1 & 593 & 16.5 & -- & 0.2 & 140 & -- & -- & -- & -- \\
\hline $6 / 25 / 2009$ & 1210 & 0.1 & 7.1 & 593 & 16.5 & -- & 0.2 & 140 & -- & -- & -- & -- \\
\hline $6 / 25 / 2009$ & 1211 & -- & -- & -- & -- & -- & -- & -- & 347 & 220 & $<4$ & 198 \\
\hline $6 / 25 / 2009$ & 1215 & 0.1 & 7.1 & 593 & 16.5 & -- & 0.2 & 140 & -- & -- & -- & -- \\
\hline $7 / 14 / 2009$ & 1200 & 0.2 & 6.9 & 648 & 16.5 & -- & 0.3 & 160 & -- & -- & -- & -- \\
\hline $7 / 14 / 2009$ & 1201 & -- & -- & -- & -- & -- & -- & -- & 363 & 240 & $<4$ & 202 \\
\hline $7 / 14 / 2009$ & 1205 & 0.2 & 6.9 & 648 & 16.5 & -- & 0.3 & 160 & -- & -- & -- & -- \\
\hline $8 / 19 / 2009$ & 1125 & 0.1 & 7.1 & 600 & 16.1 & -- & 0.1 & 140 & -- & -- & -- & -- \\
\hline $8 / 19 / 2009$ & 1126 & -- & -- & -- & -- & -- & -- & -- & 358 & 220 & $<4$ & 200 \\
\hline $8 / 19 / 2009$ & 1130 & 0.1 & 7.1 & 600 & 16.1 & -- & 0.1 & 140 & -- & -- & -- & -- \\
\hline $11 / 18 / 2009$ & 1130 & 0.2 & 7.4 & 655 & 16.0 & -- & 0.1 & 180 & -- & -- & -- & -- \\
\hline $11 / 18 / 2009$ & 1131 & -- & -- & -- & -- & -- & -- & -- & 386 & 240 & $<4$ & 197 \\
\hline $11 / 18 / 2009$ & 1135 & 0.2 & 7.4 & 655 & 16.0 & -- & 0.1 & 180 & -- & -- & -- & -- \\
\hline $3 / 8 / 2010$ & 1145 & 0.2 & 7.3 & 624 & 15.7 & -- & 0.1 & -- & -- & -- & -- & -- \\
\hline $3 / 8 / 2010$ & 1146 & -- & -- & -- & -- & -- & -- & -- & 350 & 220 & $<10$ & 204 \\
\hline $3 / 8 / 2010$ & 1150 & 0.2 & 7.3 & 624 & 15.7 & -- & 0.1 & -- & -- & -- & -- & -- \\
\hline \multicolumn{13}{|c|}{ RB1-MS shallow } \\
\hline $8 / 29 / 2006$ & 1200 & -- & -- & -- & -- & -- & -- & -- & -- & -- & -- & -- \\
\hline $8 / 30 / 2006$ & 1030 & M & 7.1 & 573 & 16.1 & -- & 5.6 & 150 & -- & -- & -- & -- \\
\hline $8 / 30 / 2006$ & 1031 & -- & -- & -- & -- & -- & -- & -- & 356 & 180 & $<4$ & 184 \\
\hline $8 / 30 / 2006$ & 1035 & M & 7.1 & 573 & 16.1 & -- & 5.6 & 150 & -- & -- & -- & -- \\
\hline $11 / 29 / 2006$ & 1010 & 0.1 & 7.1 & 566 & 15.3 & -- & 5.4 & 120 & -- & -- & -- & -- \\
\hline $11 / 29 / 2006$ & 1011 & -- & -- & -- & -- & -- & -- & -- & 325 & 180 & $<4$ & 178 \\
\hline $2 / 23 / 2007$ & 1030 & 0.2 & 7.0 & 563 & 15.6 & -- & 2.5 & 150 & -- & -- & -- & -- \\
\hline $2 / 23 / 2007$ & 1031 & -- & -- & -- & -- & -- & -- & -- & 336 & 180 & 4 & 180 \\
\hline $2 / 23 / 2007$ & 1032 & -- & -- & -- & -- & -- & -- & -- & -- & -- & -- & -- \\
\hline $6 / 4 / 2007$ & 1020 & 0.6 & 7.0 & 561 & 16.3 & -- & 0.4 & 140 & -- & -- & -- & -- \\
\hline $6 / 4 / 2007$ & 1021 & -- & -- & -- & -- & -- & -- & -- & 347 & 180 & $<10$ & 176 \\
\hline
\end{tabular}


$\left[\mathrm{mg} / \mathrm{L}\right.$, milligrams per liter; $\mu \mathrm{S} / \mathrm{cm}$, microsiemens per centimeter at 25 degrees Celsius; ${ }^{\circ} \mathrm{C}$, degrees Celsius; +/-, plus or minus; NTU, nephelometric turbidity units; NTRU, nephelometric turbidity ratiometric units; $\mathrm{mV}$, millivolts; $\mathrm{CaCO}_{3}$, calcium carbonate; --, not determined or not applicable; <, less than; $\mathrm{M}^{*}$, presence of material verified, but not quantified; $\mathrm{E}^{* *}$, estimated]

\begin{tabular}{|c|c|c|c|c|c|c|c|c|c|c|c|c|}
\hline $\begin{array}{c}\text { Date of } \\
\text { sample } \\
\text { collection } \\
\text { (month/day/ } \\
\text { year) }\end{array}$ & $\begin{array}{c}\text { Sample } \\
\text { start } \\
\text { time }\end{array}$ & $\begin{array}{l}\text { Dissolved } \\
\text { oxygen } \\
\text { (mg/L) }\end{array}$ & $\begin{array}{l}\text { pH, field } \\
\text { (standard } \\
\text { units) }\end{array}$ & 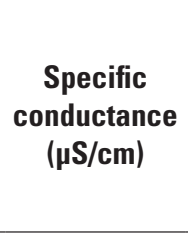 & $\begin{array}{c}\text { Water } \\
\text { temperature } \\
\left({ }^{\circ} \mathrm{C}\right)\end{array}$ & $\begin{array}{c}\text { Turbdity, } \\
\text { detection } \\
\text { angle } 90+/-30 \\
\text { degrees } \\
\text { (NTU) }\end{array}$ & $\begin{array}{l}\text { Turbidity, detectors } \\
\text { at multiple angles } \\
\text { including } \\
90+/-30 \text { degrees, } \\
\text { radiometric correction } \\
\text { (NTRU) }\end{array}$ & $\begin{array}{c}\text { Oxidation- } \\
\text { reduction (redox) } \\
\text { potential } \\
\text { (mV relative to the } \\
\text { standard hydrogen } \\
\text { electrode) } \\
\end{array}$ & $\begin{array}{l}\text { Dissolved } \\
\text { solids } \\
\text { (mg/L) }\end{array}$ & $\begin{array}{c}\text { Hardness } \\
\text { as } \mathrm{CaCO}_{3} \\
(\mathrm{mg} / \mathrm{L})\end{array}$ & $\begin{array}{l}\text { Suspended } \\
\text { solids } \\
\text { (mg/L) }\end{array}$ & $\begin{array}{c}\text { Alkalinity } \\
\text { as } \mathrm{CaCO}_{3} \\
\text { (mg/L) }\end{array}$ \\
\hline \multicolumn{13}{|c|}{ RB1-MS shallow-Continued } \\
\hline $8 / 29 / 2007$ & 1015 & 0.4 & 7.1 & 541 & 16.3 & -- & 0.5 & 150 & -- & -- & -- & -- \\
\hline $8 / 29 / 2007$ & 1016 & -- & -- & -- & -- & -- & -- & -- & 334 & 180 & $<4$ & 184 \\
\hline $8 / 29 / 2007$ & 1020 & 0.4 & 7.1 & 541 & 16.3 & -- & 0.5 & 150 & -- & -- & -- & -- \\
\hline $3 / 4 / 2008$ & 1015 & 0.1 & 7.0 & 526 & 15.5 & -- & 0.9 & 150 & -- & -- & -- & -- \\
\hline $3 / 4 / 2008$ & 1016 & -- & -- & -- & -- & -- & -- & -- & 323 & 180 & $<4$ & 176 \\
\hline $8 / 18 / 2008$ & 1030 & 0.1 & 6.9 & 527 & 16.2 & -- & 2.6 & 120 & -- & -- & -- & -- \\
\hline $8 / 18 / 2008$ & 1031 & -- & -- & -- & -- & -- & -- & -- & 326 & 180 & $<4$ & 184 \\
\hline $8 / 18 / 2008$ & 1032 & -- & -- & -- & -- & -- & -- & -- & -- & -- & -- & -- \\
\hline $8 / 18 / 2008$ & 1035 & 0.1 & 6.9 & 527 & 16.2 & -- & 2.6 & 120 & -- & -- & -- & -- \\
\hline $2 / 4 / 2009$ & 1005 & 0.5 & 6.6 & 531 & 14.9 & -- & 1.4 & 170 & -- & -- & -- & -- \\
\hline 2/4/2009 & 1006 & -- & -- & -- & -- & -- & -- & -- & 329 & 180 & $<4$ & 192 \\
\hline $3 / 24 / 2009$ & 1135 & 3.0 & 6.7 & 530 & 15.6 & -- & 2.1 & 180 & -- & -- & -- & -- \\
\hline $3 / 24 / 2009$ & 1136 & -- & -- & -- & -- & -- & -- & -- & 333 & 190 & $<4$ & 184 \\
\hline $3 / 24 / 2009$ & 1140 & 3.0 & 6.7 & 530 & 15.6 & -- & 2.1 & 180 & -- & -- & -- & -- \\
\hline 4/6/2009 & 1010 & 0.3 & 6.7 & 531 & 15.1 & -- & 2.3 & 170 & -- & -- & -- & -- \\
\hline 4/6/2009 & 1011 & -- & -- & -- & -- & -- & -- & -- & 331 & 190 & 9 & 180 \\
\hline 4/6/2009 & 1015 & 0.3 & 6.7 & 531 & 15.1 & -- & 2.3 & 170 & -- & -- & -- & -- \\
\hline 4/9/2009 & 1005 & 0.2 & 6.7 & 528 & 15.8 & -- & 0.9 & 170 & -- & -- & -- & -- \\
\hline 4/9/2009 & 1006 & -- & -- & -- & -- & -- & -- & -- & 326 & 190 & $<4$ & 188 \\
\hline 4/9/2009 & 1010 & 0.2 & 6.7 & 528 & 15.8 & -- & 0.9 & 170 & -- & -- & -- & -- \\
\hline $4 / 16 / 2009$ & 1015 & 0.1 & 7.0 & 537 & 15.9 & -- & 0.7 & 120 & -- & -- & -- & -- \\
\hline $4 / 16 / 2009$ & 1016 & -- & -- & -- & -- & -- & -- & -- & 330 & 180 & $<4$ & 178 \\
\hline $4 / 20 / 2009$ & 1005 & 0.2 & 6.8 & 531 & 15.8 & -- & 0.5 & 150 & -- & -- & -- & -- \\
\hline $4 / 20 / 2009$ & 1006 & -- & -- & -- & -- & -- & -- & -- & 329 & 190 & $<4$ & 183 \\
\hline $5 / 6 / 2009$ & 1025 & 0.1 & 7.1 & 538 & 16.1 & -- & 1.5 & 160 & -- & -- & -- & -- \\
\hline $5 / 6 / 2009$ & 1026 & -- & -- & -- & -- & -- & -- & -- & 318 & 180 & $<4$ & 182 \\
\hline $5 / 6 / 2009$ & 1030 & 0.1 & 7.1 & 538 & 16.1 & -- & 1.5 & 160 & -- & -- & -- & -- \\
\hline $5 / 20 / 2009$ & 1005 & 0.1 & 6.8 & 529 & 16.2 & -- & 0.8 & 160 & -- & -- & -- & -- \\
\hline $5 / 20 / 2009$ & 1006 & -- & -- & -- & -- & -- & -- & -- & 328 & 180 & $<4$ & 180 \\
\hline $5 / 20 / 2009$ & 1010 & 0.1 & 6.8 & 529 & 16.2 & -- & 0.8 & 160 & -- & -- & -- & -- \\
\hline $6 / 25 / 2009$ & 1000 & 0.1 & 7.2 & 533 & 16.6 & -- & 0.9 & 160 & -- & -- & -- & -- \\
\hline $6 / 25 / 2009$ & 1001 & -- & -- & -- & -- & -- & -- & -- & 335 & 180 & $<4$ & 180 \\
\hline
\end{tabular}


Table 5. Summary of physical property data from water samples collected as part of the Equus Beds Experimental Passive Recharge Project at RB1, 2009-2010.-Continued [mg/L, milligrams per liter; $\mu \mathrm{S} / \mathrm{cm}$, microsiemens per centimeter at 25 degrees Celsius; ${ }^{\circ} \mathrm{C}$, degrees Celsius; +/-, plus or minus; NTU, nephelometric turbidity units; NTRU, nephelometric turbidity ratiometric units; $\mathrm{mV}$, millivolts; $\mathrm{CaCO}_{3}$, calcium carbonate; --, not determined or not applicable; <, less than; $\mathrm{M}^{*}$, presence of material verified, but not quantified; $\mathrm{E}^{* *}$, estimated]

\begin{tabular}{|c|c|c|c|c|c|c|c|c|c|c|c|c|}
\hline $\begin{array}{l}\text { Date of } \\
\text { sample } \\
\text { collection } \\
\text { (month/day/ } \\
\text { year) }\end{array}$ & $\begin{array}{c}\text { Sample } \\
\text { start } \\
\text { time }\end{array}$ & $\begin{array}{c}\text { Dissolved } \\
\text { oxygen } \\
\text { (mg/L) }\end{array}$ & $\begin{array}{c}\text { pH, field } \\
\text { (standard } \\
\text { units) }\end{array}$ & $\begin{array}{c}\text { Specific } \\
\text { conductance } \\
(\mu \mathrm{S} / \mathrm{cm})\end{array}$ & $\begin{array}{c}\text { Water } \\
\text { temperature } \\
\left({ }^{\circ} \mathrm{C}\right)\end{array}$ & $\begin{array}{l}\text { Turbdity, } \\
\text { detection } \\
\text { angle } 90+/-30 \\
\text { degrees } \\
\text { (NTU) }\end{array}$ & $\begin{array}{l}\text { Turbidity, detectors } \\
\text { at multiple angles } \\
\text { including } \\
90+/-30 \text { degrees, } \\
\text { radiometric correction } \\
\text { (NTRU) }\end{array}$ & $\begin{array}{c}\text { Oxidation- } \\
\text { reduction (redox) } \\
\text { potential } \\
\text { (mV relative to the } \\
\text { standard hydrogen } \\
\text { electrode) }\end{array}$ & $\begin{array}{l}\text { Dissolved } \\
\text { solids } \\
\text { (mg/L) }\end{array}$ & $\begin{array}{c}\text { Hardness } \\
\text { as } \mathrm{CaCO}_{3} \\
(\mathrm{mg} / \mathrm{L})\end{array}$ & $\begin{array}{l}\text { Suspended } \\
\text { solids } \\
\text { (mg/L) }\end{array}$ & $\begin{array}{c}\text { Alkalinity } \\
\text { as } \mathrm{CaCO}_{3} \\
\text { (mg/L) }\end{array}$ \\
\hline \multicolumn{13}{|c|}{ RB1-MS shallow-Continued } \\
\hline $6 / 25 / 2009$ & 1005 & 0.1 & 7.2 & 533 & 16.6 & -- & 0.9 & 160 & -- & -- & -- & -- \\
\hline $6 / 25 / 2009$ & 1010 & 0.1 & 7.2 & 533 & 16.6 & -- & 0.9 & 160 & -- & -- & -- & -- \\
\hline $7 / 8 / 2009$ & 1020 & 0.2 & 6.9 & 533 & 17.0 & -- & 1.4 & 170 & -- & -- & -- & -- \\
\hline $7 / 8 / 2009$ & 1021 & -- & -- & -- & -- & -- & -- & -- & 333 & 190 & $<4$ & 182 \\
\hline $7 / 8 / 2009$ & 1025 & 0.2 & 6.9 & 533 & 17.0 & -- & 1.4 & 170 & -- & -- & -- & -- \\
\hline $7 / 13 / 2009$ & 1015 & 0.2 & 6.9 & 546 & 17.0 & -- & 0.6 & 200 & -- & -- & -- & -- \\
\hline $7 / 13 / 2009$ & 1016 & -- & -- & -- & -- & -- & -- & -- & 331 & 190 & $<4$ & 184 \\
\hline $7 / 13 / 2009$ & 1020 & 0.2 & 6.9 & 546 & 17.0 & -- & 0.6 & 200 & -- & -- & -- & -- \\
\hline $7 / 20 / 2009$ & 1015 & 0.3 & 6.8 & 545 & 16.7 & -- & 0.8 & 140 & -- & -- & -- & -- \\
\hline $7 / 20 / 2009$ & 1016 & -- & -- & -- & -- & -- & -- & -- & 332 & 190 & 6 & 185 \\
\hline $7 / 20 / 2009$ & 1020 & 0.3 & 6.8 & 545 & 16.7 & -- & 0.8 & 140 & -- & -- & -- & -- \\
\hline $8 / 18 / 2009$ & 1010 & 0.1 & 6.8 & 540 & 16.7 & -- & 1.1 & 180 & -- & -- & -- & -- \\
\hline $8 / 18 / 2009$ & 1011 & -- & -- & -- & -- & -- & -- & -- & 328 & 190 & 4 & 183 \\
\hline $8 / 18 / 2009$ & 1015 & 0.1 & 6.8 & 540 & 16.7 & -- & 1.1 & 180 & -- & -- & -- & -- \\
\hline $11 / 18 / 2009$ & 1005 & 2.7 & 7.1 & 528 & 15.9 & -- & 1.4 & 170 & -- & -- & -- & -- \\
\hline $11 / 18 / 2009$ & 1006 & -- & -- & -- & -- & -- & -- & -- & 327 & 180 & 4 & 170 \\
\hline $11 / 18 / 2009$ & 1010 & 2.7 & 7.1 & 528 & 15.9 & -- & 1.4 & 170 & -- & -- & -- & -- \\
\hline $3 / 1 / 2010$ & 1130 & 0.2 & 7.1 & 529 & 15.2 & -- & 2.4 & 170 & -- & -- & -- & -- \\
\hline $3 / 1 / 2010$ & 1131 & -- & -- & -- & -- & -- & -- & -- & 314 & 170 & $<10$ & 173 \\
\hline $3 / 1 / 2010$ & 1135 & 0.2 & 7.1 & 529 & 15.2 & -- & 2.4 & 170 & -- & -- & -- & -- \\
\hline \multicolumn{13}{|c|}{ RB1-MS deep } \\
\hline $8 / 29 / 2006$ & 1200 & -- & -- & -- & -- & -- & -- & -- & -- & -- & -- & -- \\
\hline $8 / 30 / 2006$ & 1245 & M & 7.3 & 551 & 16.0 & -- & 0.6 & 150 & -- & -- & -- & -- \\
\hline $8 / 30 / 2006$ & 1246 & -- & -- & -- & -- & -- & -- & -- & 330 & 200 & $<4$ & 197 \\
\hline $8 / 30 / 2006$ & 1250 & M & 7.3 & 551 & 16.0 & -- & 0.6 & 150 & -- & -- & -- & -- \\
\hline $12 / 4 / 2006$ & 1000 & 0.1 & 7.1 & 563 & 15.6 & -- & 0.7 & 130 & -- & -- & -- & -- \\
\hline $12 / 4 / 2006$ & 1001 & -- & -- & -- & -- & -- & -- & -- & 357 & 200 & $<4$ & 193 \\
\hline $2 / 23 / 2007$ & 1145 & 0.1 & 7.3 & 561 & 15.8 & -- & 0.7 & 140 & -- & -- & -- & -- \\
\hline $2 / 23 / 2007$ & 1146 & -- & -- & -- & -- & -- & -- & -- & 324 & 190 & $<4$ & 194 \\
\hline $6 / 4 / 2007$ & 1150 & 0.1 & 7.2 & 554 & 16.2 & -- & 0.2 & 130 & -- & -- & -- & -- \\
\hline $6 / 4 / 2007$ & 1151 & -- & -- & -- & -- & -- & -- & -- & 324 & 190 & $<10$ & 194 \\
\hline $8 / 29 / 2007$ & 1205 & 0.1 & 7.3 & 550 & 16.2 & -- & 0.2 & 150 & -- & -- & -- & -- \\
\hline
\end{tabular}


$\left[\mathrm{mg} / \mathrm{L}\right.$, milligrams per liter; $\mu \mathrm{S} / \mathrm{cm}$, microsiemens per centimeter at 25 degrees Celsius; ${ }^{\circ} \mathrm{C}$, degrees Celsius; +/-, plus or minus; NTU, nephelometric turbidity units; NTRU, nephelometric turbidity ratiometric units; $\mathrm{mV}$, millivolts; $\mathrm{CaCO}_{3}$, calcium carbonate; --, not determined or not applicable; <, less than; $\mathrm{M}^{*}$, presence of material verified, but not quantified; $\mathrm{E}^{* *}$, estimated]

\begin{tabular}{|c|c|c|c|c|c|c|c|c|c|c|c|c|}
\hline $\begin{array}{c}\text { Date of } \\
\text { sample } \\
\text { collection } \\
\text { (month/day/ } \\
\text { year) }\end{array}$ & $\begin{array}{c}\text { Sample } \\
\text { start } \\
\text { time }\end{array}$ & $\begin{array}{c}\text { Dissolved } \\
\text { oxygen } \\
\text { (mg/L) }\end{array}$ & $\begin{array}{c}\text { pH, field } \\
\text { (standard } \\
\text { units) }\end{array}$ & 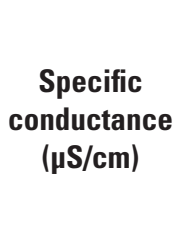 & $\begin{array}{c}\text { Water } \\
\text { temperature } \\
\left({ }^{\circ} \mathrm{C}\right)\end{array}$ & $\begin{array}{c}\text { Turbdity, } \\
\text { detection } \\
\text { angle } 90+/-30 \\
\text { degrees } \\
\text { (NTU) }\end{array}$ & $\begin{array}{l}\text { Turbidity, detectors } \\
\text { at multiple angles } \\
\text { including } \\
90+/-30 \text { degrees, } \\
\text { radiometric correction } \\
\text { (NTRU) }\end{array}$ & $\begin{array}{c}\text { Oxidation- } \\
\text { reduction (redox) } \\
\text { potential } \\
\text { (mV relative to the } \\
\text { standard hydrogen } \\
\text { electrode) }\end{array}$ & $\begin{array}{l}\text { Dissolved } \\
\text { solids } \\
\text { (mg/L) }\end{array}$ & $\begin{array}{c}\text { Hardness } \\
\text { as } \mathrm{CaCO}_{3} \\
(\mathrm{mg} / \mathrm{L})\end{array}$ & $\begin{array}{l}\text { Suspended } \\
\text { solids } \\
\text { (mg/L) }\end{array}$ & $\begin{array}{c}\text { Alkalinity } \\
\text { as } \mathrm{CaCO}_{3} \\
\text { (mg/L) }\end{array}$ \\
\hline \multicolumn{13}{|c|}{ RB1-MS deep-Continued } \\
\hline $8 / 29 / 2007$ & 1206 & -- & -- & -- & -- & -- & -- & -- & 321 & 190 & $<4$ & 192 \\
\hline $8 / 29 / 2007$ & 1210 & 0.1 & 7.3 & 550 & 16.2 & -- & 0.2 & 150 & -- & -- & -- & -- \\
\hline $3 / 4 / 2008$ & 1200 & 0.1 & 7.1 & 540 & 15.6 & -- & 0.2 & 150 & -- & -- & -- & -- \\
\hline $3 / 4 / 2008$ & 1201 & -- & -- & -- & -- & -- & -- & -- & 309 & 200 & $<4$ & 188 \\
\hline $8 / 18 / 2008$ & 1230 & 0.1 & 7.2 & 562 & 16.0 & -- & 0.3 & 60 & -- & -- & -- & -- \\
\hline $8 / 18 / 2008$ & 1231 & -- & -- & -- & -- & -- & -- & -- & 326 & 210 & $<4$ & 194 \\
\hline $8 / 18 / 2008$ & 1235 & 0.1 & 7.2 & 562 & 16.0 & -- & 0.3 & 60 & -- & -- & -- & -- \\
\hline 2/4/2009 & 1140 & 0.1 & 7.0 & 503 & 15.4 & -- & 0.3 & 100 & -- & -- & -- & -- \\
\hline 2/4/2009 & 1141 & -- & -- & -- & -- & -- & -- & -- & 283 & 190 & $<4$ & 192 \\
\hline $3 / 24 / 2009$ & 1305 & 0.1 & 7.1 & 536 & 15.8 & -- & 0.4 & 40 & -- & -- & -- & -- \\
\hline $3 / 24 / 2009$ & 1306 & -- & -- & -- & -- & -- & -- & -- & 311 & 200 & $<4$ & 188 \\
\hline $3 / 24 / 2009$ & 1310 & 0.1 & 7.1 & 536 & 15.8 & -- & 0.4 & 40 & -- & -- & -- & -- \\
\hline 4/6/2009 & 1140 & 0.2 & 7.0 & 517 & 15.4 & -- & 0.3 & 160 & -- & -- & -- & -- \\
\hline $4 / 6 / 2009$ & 1141 & -- & -- & -- & -- & -- & -- & -- & 303 & 200 & $<4$ & 187 \\
\hline $4 / 6 / 2009$ & 1145 & 0.2 & 7.0 & 517 & 15.4 & -- & 0.3 & 160 & -- & -- & -- & -- \\
\hline 4/9/2009 & 1135 & 0.1 & 7.1 & 513 & 15.8 & -- & 0.3 & 150 & -- & -- & -- & -- \\
\hline 4/9/2009 & 1136 & -- & -- & -- & -- & -- & -- & -- & 301 & 200 & $<4$ & 194 \\
\hline 4/9/2009 & 1140 & 0.1 & 7.1 & 513 & 15.8 & -- & 0.3 & 150 & -- & -- & -- & -- \\
\hline $4 / 16 / 2009$ & 1140 & 0.1 & 7.3 & 519 & 15.8 & -- & 0.2 & 120 & -- & -- & -- & -- \\
\hline $4 / 16 / 2009$ & 1141 & -- & -- & -- & -- & -- & -- & -- & 304 & 200 & $<4$ & 188 \\
\hline $4 / 20 / 2009$ & 1135 & 0.1 & 7.1 & 521 & 15.8 & -- & 0.3 & 150 & -- & -- & -- & -- \\
\hline $4 / 20 / 2009$ & 1136 & -- & -- & -- & -- & -- & -- & -- & 309 & 200 & $<4$ & 192 \\
\hline $5 / 6 / 2009$ & 1150 & 0.1 & 7.4 & 528 & 16.0 & -- & 0.1 & 140 & -- & -- & -- & -- \\
\hline $5 / 6 / 2009$ & 1151 & -- & -- & -- & -- & -- & -- & -- & 314 & 200 & $<4$ & 192 \\
\hline $5 / 6 / 2009$ & 1155 & 0.1 & 7.4 & 528 & 16.0 & -- & 0.1 & 140 & -- & -- & -- & -- \\
\hline $5 / 20 / 2009$ & 1140 & M & 7.1 & 519 & 16.0 & -- & 0.4 & 160 & -- & -- & -- & -- \\
\hline $5 / 20 / 2009$ & 1141 & -- & -- & -- & -- & -- & -- & -- & 300 & 200 & $<4$ & 192 \\
\hline $5 / 20 / 2009$ & 1145 & M & 7.1 & 519 & 16.0 & -- & 0.4 & 160 & -- & -- & -- & -- \\
\hline $6 / 25 / 2009$ & 1145 & 0.2 & 7.5 & 532 & 16.2 & -- & 0.5 & 150 & -- & -- & -- & -- \\
\hline $6 / 25 / 2009$ & 1146 & -- & -- & -- & -- & -- & -- & -- & 311 & 200 & $<4$ & 192 \\
\hline $6 / 25 / 2009$ & 1150 & 0.2 & 7.5 & 532 & 16.2 & -- & 0.5 & 150 & -- & -- & -- & -- \\
\hline $6 / 25 / 2009$ & 1155 & 0.2 & 7.5 & 532 & 16.2 & -- & 0.5 & 150 & -- & -- & -- & -- \\
\hline
\end{tabular}


Table 5. Summary of physical property data from water samples collected as part of the Equus Beds Experimental Passive Recharge Project at RB1, 2009-2010.—Continued [mg/L, milligrams per liter; $\mu \mathrm{S} / \mathrm{cm}$, microsiemens per centimeter at 25 degrees Celsius; ${ }^{\circ} \mathrm{C}$, degrees Celsius; $+/-$, plus or minus; NTU, nephelometric turbidity units; NTRU, nephelometric turbidity ratiometric units; $\mathrm{mV}$, millivolts; $\mathrm{CaCO}_{3}$, calcium carbonate; --, not determined or not applicable; <, less than; $\mathrm{M}^{*}$, presence of material verified, but not quantified; $\mathrm{E}^{* *}$, estimated]

\begin{tabular}{|c|c|c|c|c|c|c|c|c|c|c|c|c|}
\hline $\begin{array}{c}\text { Date of } \\
\text { sample } \\
\text { collection } \\
\text { (month/day/ } \\
\text { year) }\end{array}$ & $\begin{array}{c}\text { Sample } \\
\text { start } \\
\text { time }\end{array}$ & $\begin{array}{l}\text { Dissolved } \\
\text { oxygen } \\
\text { (mg/L) }\end{array}$ & $\begin{array}{c}\text { pH, field } \\
\text { (standard } \\
\text { units) }\end{array}$ & $\begin{array}{c}\text { Specific } \\
\text { conductance } \\
(\mu \mathrm{S} / \mathrm{cm})\end{array}$ & $\begin{array}{c}\text { Water } \\
\text { temperature } \\
\left({ }^{\circ} \mathrm{C}\right)\end{array}$ & $\begin{array}{l}\text { Turbdity, } \\
\text { detection } \\
\text { angle } 90+/-30 \\
\text { degrees } \\
\text { (NTU) }\end{array}$ & $\begin{array}{l}\text { Turbidity, detectors } \\
\text { at multiple angles } \\
\text { including } \\
90+/-30 \text { degrees, } \\
\text { radiometric correction } \\
\text { (NTRU) }\end{array}$ & $\begin{array}{c}\text { Oxidation- } \\
\text { reduction (redox) } \\
\text { potential } \\
\text { (mV relative to the } \\
\text { standard hydrogen } \\
\text { electrode) }\end{array}$ & $\begin{array}{l}\text { Dissolved } \\
\text { solids } \\
\text { (mg/L) }\end{array}$ & $\begin{array}{c}\text { Hardness } \\
\text { as } \mathrm{CaCO}_{3} \\
(\mathrm{mg} / \mathrm{L})\end{array}$ & $\begin{array}{l}\text { Suspended } \\
\text { solids } \\
\text { (mg/L) }\end{array}$ & $\begin{array}{c}\text { Alkalinity } \\
\text { as } \mathrm{CaCO}_{3} \\
\text { (mg/L) }\end{array}$ \\
\hline \multicolumn{13}{|c|}{ RB1-MS deep-Continued } \\
\hline $7 / 8 / 2009$ & 1205 & 0.1 & 7.2 & 522 & 16.6 & -- & 0.3 & 260 & -- & -- & -- & -- \\
\hline $7 / 8 / 2009$ & 1206 & -- & -- & -- & -- & -- & -- & -- & 307 & 190 & $<4$ & 193 \\
\hline $7 / 8 / 2009$ & 1210 & 0.1 & 7.2 & 522 & 16.6 & -- & 0.3 & 260 & -- & -- & -- & -- \\
\hline $7 / 13 / 2009$ & 1155 & 0.1 & 7.2 & 522 & 16.6 & -- & 0.4 & 180 & -- & -- & -- & -- \\
\hline $7 / 13 / 2009$ & 1156 & -- & -- & -- & -- & -- & -- & -- & 286 & 190 & $<4$ & 192 \\
\hline $7 / 13 / 2009$ & 1200 & 0.1 & 7.2 & 522 & 16.6 & -- & 0.4 & 180 & -- & -- & -- & -- \\
\hline $7 / 20 / 2009$ & 1240 & 0.2 & 7.0 & 515 & 16.6 & -- & 0.4 & 170 & -- & -- & -- & -- \\
\hline $7 / 20 / 2009$ & 1241 & -- & -- & -- & -- & -- & -- & -- & 297 & 190 & $<4$ & 195 \\
\hline $7 / 20 / 2009$ & 1245 & 0.2 & 7.0 & 515 & 16.6 & -- & 0.4 & 170 & -- & -- & -- & -- \\
\hline $8 / 18 / 2009$ & 1145 & 0.1 & 7.1 & 496 & 16.3 & -- & 0.1 & 160 & -- & -- & -- & -- \\
\hline $8 / 18 / 2009$ & 1146 & -- & -- & -- & -- & -- & -- & -- & 294 & 180 & $<4$ & 188 \\
\hline $8 / 18 / 2009$ & 1150 & 0.1 & 7.1 & 496 & 16.3 & -- & 0.1 & 160 & -- & -- & -- & -- \\
\hline $11 / 18 / 2009$ & 1135 & 0.1 & 7.4 & 488 & 15.7 & -- & 0.6 & 160 & -- & -- & -- & -- \\
\hline $11 / 18 / 2009$ & 1136 & -- & -- & -- & -- & -- & -- & -- & 331 & 180 & $<4$ & 188 \\
\hline $11 / 18 / 2009$ & 1140 & 0.1 & 7.4 & 488 & 15.7 & -- & 0.6 & 160 & -- & -- & -- & -- \\
\hline $3 / 1 / 2010$ & 1255 & 0.2 & 7.5 & 495 & 15.5 & -- & 0.4 & 190 & -- & -- & -- & -- \\
\hline $3 / 1 / 2010$ & 1256 & -- & -- & -- & -- & -- & -- & -- & 276 & 180 & $<10$ & 189 \\
\hline $3 / 1 / 2010$ & 1300 & 0.2 & 7.5 & 495 & 15.5 & -- & 0.4 & 190 & -- & -- & -- & -- \\
\hline \multicolumn{13}{|c|}{ RB1-PMS shallow } \\
\hline $1 / 22 / 2009$ & 1415 & 0.3 & 6.7 & 556 & 16.1 & -- & 0.3 & 320 & -- & -- & -- & -- \\
\hline $1 / 22 / 2009$ & 1416 & -- & -- & -- & -- & -- & -- & -- & 343 & 190 & $<4$ & 148 \\
\hline $2 / 2 / 2009$ & 1035 & 0.3 & 6.3 & 563 & 15.2 & -- & 0.5 & 400 & -- & -- & -- & -- \\
\hline $2 / 2 / 2009$ & 1036 & -- & -- & -- & -- & -- & -- & -- & 331 & 190 & $<4$ & 147 \\
\hline $2 / 11 / 2009$ & 1146 & 0.6 & 6.8 & 485 & 10.5 & -- & -- & -- & -- & -- & -- & -- \\
\hline $2 / 11 / 2009$ & 1147 & 0.5 & 6.8 & 486 & 11.6 & -- & -- & -- & -- & -- & -- & -- \\
\hline $2 / 11 / 2009$ & 1148 & 0.4 & 6.8 & 486 & 13.1 & -- & -- & -- & -- & -- & -- & -- \\
\hline $2 / 11 / 2009$ & 1149 & 0.4 & 6.8 & 490 & 14.6 & -- & -- & -- & -- & -- & -- & -- \\
\hline $2 / 11 / 2009$ & 1150 & 0.3 & 7.3 & 490 & 15.3 & -- & -- & -- & -- & -- & -- & -- \\
\hline $2 / 11 / 2009$ & 1151 & 0.3 & 7.5 & 489 & 15.4 & -- & -- & -- & -- & -- & -- & -- \\
\hline $2 / 11 / 2009$ & 1152 & 0.3 & 7.5 & 494 & 15.3 & -- & -- & -- & -- & -- & -- & -- \\
\hline $2 / 11 / 2009$ & 1153 & 0.3 & 7.2 & 506 & 15.3 & -- & -- & -- & -- & -- & -- & -- \\
\hline $2 / 11 / 2009$ & 1154 & 0.3 & 7.2 & 543 & 15.3 & -- & -- & -- & -- & -- & -- & -- \\
\hline
\end{tabular}


[mg/L, milligrams per liter; $\mu \mathrm{S} / \mathrm{cm}$, microsiemens per centimeter at 25 degrees Celsius; ${ }^{\circ} \mathrm{C}$, degrees Celsius; +/-, plus or minus; NTU, nephelometric turbidity units; NTRU, nephelometric turbidity ratiometric units; $\mathrm{mV}$, millivolts; $\mathrm{CaCO}_{3}$, calcium carbonate; --, not determined or not applicable; <, less than; $\mathrm{M}^{*}$, presence of material verified, but not quantified; $\mathrm{E}^{* *}$, estimated]

\begin{tabular}{|c|c|c|c|c|c|c|c|c|c|c|c|c|}
\hline $\begin{array}{c}\text { Date of } \\
\text { sample } \\
\text { collection } \\
\text { (month/day/ } \\
\text { year) }\end{array}$ & $\begin{array}{c}\text { Sample } \\
\text { start } \\
\text { time }\end{array}$ & $\begin{array}{c}\text { Dissolved } \\
\text { oxygen } \\
\text { (mg/L) }\end{array}$ & $\begin{array}{c}\text { pH, field } \\
\text { (standard } \\
\text { units) }\end{array}$ & $\begin{array}{c}\text { Specific } \\
\text { conductance } \\
(\mu \mathrm{S} / \mathrm{cm})\end{array}$ & $\begin{array}{c}\text { Water } \\
\text { temperature } \\
\left({ }^{\circ} \mathrm{C}\right)\end{array}$ & $\begin{array}{c}\text { Turbdity, } \\
\text { detection } \\
\text { angle } 90+/-30 \\
\text { degrees } \\
\text { (NTU) }\end{array}$ & $\begin{array}{c}\text { Turbidity, detectors } \\
\text { at multiple angles } \\
\text { including } \\
90+/-30 \text { degrees, } \\
\text { radiometric correction } \\
\text { (NTRU) }\end{array}$ & $\begin{array}{c}\text { Oxidation- } \\
\text { reduction (redox) } \\
\text { potential } \\
\text { (mV relative to the } \\
\text { standard hydrogen } \\
\text { electrode) }\end{array}$ & $\begin{array}{c}\text { Dissolved } \\
\text { solids } \\
\text { (mg/L) }\end{array}$ & $\begin{array}{c}\text { Hardness } \\
\text { as } \mathrm{CaCO}_{3} \\
(\mathrm{mg} / \mathrm{L})\end{array}$ & $\begin{array}{l}\text { Suspended } \\
\text { solids } \\
\text { (mg/L) }\end{array}$ & $\begin{array}{c}\text { Alkalinity } \\
\text { as } \mathrm{CaCO}_{3} \\
\text { (mg/L) }\end{array}$ \\
\hline \multicolumn{13}{|c|}{ RB1-PMS shallow-Continued } \\
\hline $2 / 11 / 2009$ & 1155 & 0.3 & 7.2 & 571 & 15.2 & -- & -- & -- & -- & -- & -- & -- \\
\hline $2 / 11 / 2009$ & 1156 & 0.3 & 7.2 & 571 & 15.2 & -- & -- & -- & -- & -- & -- & -- \\
\hline $2 / 11 / 2009$ & 1157 & 0.3 & 7.2 & 571 & 15.3 & -- & -- & -- & -- & -- & -- & -- \\
\hline $2 / 11 / 2009$ & 1158 & 0.3 & 7.2 & 573 & 15.3 & -- & -- & -- & -- & -- & -- & -- \\
\hline $2 / 11 / 2009$ & 1159 & 0.3 & 7.2 & 575 & 15.3 & -- & -- & -- & -- & -- & -- & -- \\
\hline $2 / 11 / 2009$ & 1200 & 0.3 & 7.2 & 576 & 15.3 & -- & -- & -- & -- & -- & -- & -- \\
\hline $3 / 9 / 2009$ & 1030 & 1.0 & 7.2 & 525 & 11.5 & -- & -- & -- & -- & -- & -- & -- \\
\hline $3 / 9 / 2009$ & 1032 & 0.8 & 7.2 & 524 & 11.6 & -- & -- & -- & -- & -- & -- & -- \\
\hline $3 / 9 / 2009$ & 1034 & 0.3 & 7.1 & 522 & 12.4 & -- & -- & -- & -- & -- & -- & -- \\
\hline $3 / 9 / 2009$ & 1035 & 0.2 & 7.1 & 521 & 13.7 & -- & -- & -- & -- & -- & -- & -- \\
\hline $3 / 9 / 2009$ & 1037 & 0.1 & 7.1 & 523 & 14.7 & -- & -- & -- & -- & -- & -- & -- \\
\hline $3 / 9 / 2009$ & 1038 & 0.1 & 7.1 & 522 & 15.2 & -- & -- & -- & -- & -- & -- & -- \\
\hline $3 / 9 / 2009$ & 1040 & 0.1 & 7.1 & 515 & 15.2 & -- & -- & -- & -- & -- & -- & -- \\
\hline $3 / 9 / 2009$ & 1042 & 0.1 & 7.1 & 528 & 15.2 & -- & -- & -- & -- & -- & -- & -- \\
\hline $3 / 9 / 2009$ & 1043 & 0.1 & 7.1 & 546 & 15.2 & -- & -- & -- & -- & -- & -- & -- \\
\hline $3 / 9 / 2009$ & 1044 & 0.1 & 7.1 & 539 & 15.2 & -- & -- & -- & -- & -- & -- & -- \\
\hline 3/9/2009 & 1045 & 0.2 & 7.1 & 588 & 15.2 & -- & -- & -- & -- & -- & -- & -- \\
\hline $3 / 26 / 2009$ & 1115 & 4.0 & 6.7 & 469 & 14.7 & -- & 1.2 & 400 & -- & -- & -- & -- \\
\hline $3 / 26 / 2009$ & 1116 & -- & -- & -- & -- & -- & -- & -- & 264 & 150 & $<4$ & 140 \\
\hline $3 / 26 / 2009$ & 1120 & 4.0 & 6.7 & 469 & 14.7 & -- & 1.2 & 400 & -- & -- & -- & -- \\
\hline $4 / 4 / 2009$ & 1005 & 3.1 & 6.7 & 482 & 14.6 & -- & 1.6 & 450 & -- & -- & -- & -- \\
\hline $4 / 4 / 2009$ & 1006 & -- & -- & -- & -- & -- & -- & -- & -- & -- & -- & -- \\
\hline $4 / 4 / 2009$ & 1010 & 3.1 & 6.7 & 482 & 14.6 & -- & 1.6 & 450 & -- & -- & -- & -- \\
\hline $4 / 8 / 2009$ & 1005 & 6.9 & 6.8 & 619 & 13.2 & -- & 1.2 & 420 & -- & -- & -- & -- \\
\hline $4 / 8 / 2009$ & 1006 & -- & -- & -- & -- & -- & -- & -- & 360 & 190 & $<4$ & 104 \\
\hline 4/8/2009 & 1010 & 6.9 & 6.8 & 619 & 13.2 & -- & 1.2 & 420 & -- & -- & -- & -- \\
\hline $4 / 15 / 2009$ & 1045 & 5.6 & 6.9 & 582 & 13.5 & -- & 4.9 & 420 & -- & -- & -- & -- \\
\hline $4 / 15 / 2009$ & 1046 & -- & -- & -- & -- & -- & -- & -- & 326 & 170 & $<4$ & 109 \\
\hline $4 / 18 / 2009$ & 1010 & 5.9 & 7.1 & 664 & 13.9 & -- & 0.9 & 310 & -- & -- & -- & -- \\
\hline $4 / 18 / 2009$ & 1011 & -- & -- & -- & -- & -- & -- & -- & 403 & 180 & $<4$ & 109 \\
\hline $5 / 6 / 2009$ & 1015 & 2.9 & 6.7 & 500 & 15.2 & -- & 2.1 & 360 & -- & -- & -- & -- \\
\hline $5 / 6 / 2009$ & 1016 & -- & -- & -- & -- & -- & -- & -- & 272 & 140 & $<4$ & 100 \\
\hline
\end{tabular}


Table 5. Summary of physical property data from water samples collected as part of the Equus Beds Experimental Passive Recharge Project at RB1, 2009-2010.-Continued [mg/L, milligrams per liter; $\mu \mathrm{S} / \mathrm{cm}$, microsiemens per centimeter at 25 degrees Celsius; ${ }^{\circ} \mathrm{C}$, degrees Celsius; +/-, plus or minus; NTU, nephelometric turbidity units; NTRU, nephelometric turbidity ratiometric units; $\mathrm{mV}$, millivolts; $\mathrm{CaCO}_{3}$, calcium carbonate; --, not determined or not applicable; <, less than; $\mathrm{M}^{*}$, presence of material verified, but not quantified; $\mathrm{E}^{* *}$, estimated]

\begin{tabular}{|c|c|c|c|c|c|c|c|c|c|c|c|c|}
\hline $\begin{array}{c}\text { Date of } \\
\text { sample } \\
\text { collection } \\
\text { (month/day/ } \\
\text { year) }\end{array}$ & $\begin{array}{c}\text { Sample } \\
\text { start } \\
\text { time }\end{array}$ & $\begin{array}{c}\text { Dissolved } \\
\text { oxygen } \\
\text { (mg/L) }\end{array}$ & $\begin{array}{l}\text { pH, field } \\
\text { (standard } \\
\text { units) }\end{array}$ & $\begin{array}{c}\text { Specific } \\
\text { conductance } \\
(\mu \mathrm{S} / \mathrm{cm})\end{array}$ & $\begin{array}{l}\text { Water } \\
\text { temperature } \\
\left({ }^{\circ} \mathrm{C}\right)\end{array}$ & $\begin{array}{c}\text { Turbdity, } \\
\text { detection } \\
\text { angle } 90+/-30 \\
\text { degrees } \\
\text { (NTU) }\end{array}$ & $\begin{array}{l}\text { Turbidity, detectors } \\
\text { at multiple angles } \\
\text { including } \\
90+/-30 \text { degrees, } \\
\text { radiometric correction } \\
\text { (NTRU) }\end{array}$ & $\begin{array}{c}\text { Oxidation- } \\
\text { reduction (redox) } \\
\text { potential } \\
\text { (mV relative to the } \\
\text { standard hydrogen } \\
\text { electrode) }\end{array}$ & $\begin{array}{l}\text { Dissolved } \\
\text { solids } \\
\text { (mg/L) }\end{array}$ & $\begin{array}{c}\text { Hardness } \\
\text { as } \mathrm{CaCO}_{3} \\
(\mathrm{mg} / \mathrm{L})\end{array}$ & $\begin{array}{l}\text { Suspended } \\
\text { solids } \\
\text { (mg/L) }\end{array}$ & $\begin{array}{c}\text { Alkalinity } \\
\text { as } \mathrm{CaCO}_{3} \\
\text { (mg/L) }\end{array}$ \\
\hline \multicolumn{13}{|c|}{ RB1-PMS shallow-Continued } \\
\hline $5 / 6 / 2009$ & 1020 & 2.9 & 6.7 & 500 & 15.2 & -- & 2.1 & 360 & -- & -- & -- & -- \\
\hline $5 / 20 / 2009$ & 1020 & 0.7 & 6.9 & 798 & 15.7 & -- & 0.5 & 300 & -- & -- & -- & -- \\
\hline $5 / 20 / 2009$ & 1021 & -- & -- & -- & -- & -- & -- & -- & 338 & 170 & $<4$ & 125 \\
\hline $5 / 20 / 2009$ & 1025 & -- & -- & -- & -- & -- & -- & -- & -- & -- & -- & -- \\
\hline 7/8/2009 & 1125 & 0.7 & 7.0 & 517 & 16.6 & -- & 0.7 & 350 & -- & -- & -- & -- \\
\hline $7 / 8 / 2009$ & 1126 & -- & -- & -- & -- & -- & -- & -- & 322 & 180 & $<4$ & 137 \\
\hline 7/8/2009 & 1135 & 0.7 & 7.0 & 517 & 16.6 & -- & 0.7 & 350 & -- & -- & -- & -- \\
\hline $7 / 13 / 2009$ & 1015 & 0.1 & 7.0 & 669 & 16.0 & -- & 1.7 & 390 & -- & -- & -- & -- \\
\hline $7 / 13 / 2009$ & 1016 & -- & -- & -- & -- & -- & -- & -- & 373 & 230 & $<4$ & 156 \\
\hline $7 / 13 / 2009$ & 1020 & 0.1 & 7.0 & 669 & 16.0 & -- & 1.7 & 390 & -- & -- & -- & -- \\
\hline $7 / 20 / 2009$ & 1025 & 0.5 & 7.0 & 767 & 16.0 & -- & 1.1 & 330 & -- & -- & -- & -- \\
\hline $7 / 20 / 2009$ & 1026 & -- & -- & -- & -- & -- & -- & -- & 423 & 240 & $<4$ & 162 \\
\hline $7 / 20 / 2009$ & 1035 & 0.5 & 7.0 & 767 & 16.0 & -- & 1.1 & 330 & -- & -- & -- & -- \\
\hline 8/18/2009 & 1010 & 0.2 & 7.0 & 541 & 16.1 & -- & 1.4 & 380 & -- & -- & -- & -- \\
\hline $8 / 18 / 2009$ & 1011 & -- & -- & -- & -- & -- & -- & -- & 320 & 180 & $<4$ & 126 \\
\hline $8 / 18 / 2009$ & 1015 & 0.2 & 7.0 & 541 & 16.1 & -- & 1.4 & 380 & -- & -- & -- & -- \\
\hline $11 / 17 / 2009$ & 0950 & 0.1 & 7.0 & 574 & 14.9 & -- & 5.8 & 340 & -- & -- & -- & -- \\
\hline $11 / 17 / 2009$ & 0951 & -- & -- & -- & -- & -- & -- & -- & 338 & 200 & $<4$ & 128 \\
\hline $11 / 17 / 2009$ & 0955 & 0.1 & 7.0 & 574 & 14.9 & -- & 5.8 & 340 & -- & -- & -- & -- \\
\hline $3 / 2 / 2010$ & 1045 & 3.0 & 7.0 & 682 & 15.2 & -- & 4.2 & 310 & -- & -- & -- & -- \\
\hline $3 / 2 / 2010$ & 1046 & -- & -- & -- & -- & -- & -- & -- & 345 & 190 & $<10$ & 133 \\
\hline $3 / 2 / 2010$ & 1050 & 3.0 & 7.0 & 682 & 15.2 & -- & 4.2 & 310 & -- & -- & -- & -- \\
\hline $3 / 2 / 2010$ & 1051 & -- & -- & -- & -- & -- & -- & -- & 350 & 190 & $<10$ & 132 \\
\hline \multicolumn{13}{|c|}{ RB1-PMS deep } \\
\hline $1 / 22 / 2009$ & 1300 & 0.3 & 6.9 & 670 & 15.9 & -- & 0.5 & 200 & -- & -- & -- & -- \\
\hline $1 / 22 / 2009$ & 1301 & -- & -- & -- & -- & -- & -- & -- & 394 & 230 & $<4$ & 164 \\
\hline $2 / 2 / 2009$ & 1205 & 0.4 & 6.7 & 568 & 15.0 & -- & 1.3 & 400 & -- & -- & -- & -- \\
\hline $2 / 2 / 2009$ & 1206 & -- & -- & -- & -- & -- & -- & -- & 339 & 190 & $<4$ & 150 \\
\hline $2 / 12 / 2009$ & 1035 & 2.5 & 6.8 & 568 & 10.8 & -- & -- & -- & -- & -- & -- & -- \\
\hline $2 / 12 / 2009$ & 1037 & 2.1 & 6.8 & 566 & 12.8 & -- & -- & -- & -- & -- & -- & -- \\
\hline $2 / 12 / 2009$ & 1038 & 1.6 & 6.8 & 560 & 14.2 & -- & -- & -- & -- & -- & -- & -- \\
\hline $2 / 12 / 2009$ & 1040 & 1.2 & 6.9 & 536 & 14.6 & -- & -- & -- & -- & -- & -- & -- \\
\hline
\end{tabular}


$\left[\mathrm{mg} / \mathrm{L}\right.$, milligrams per liter; $\mu \mathrm{S} / \mathrm{cm}$, microsiemens per centimeter at 25 degrees Celsius; ${ }^{\circ} \mathrm{C}$, degrees Celsius; +/-, plus or minus; NTU, nephelometric turbidity units; NTRU, nephelometric turbidity ratiometric units; $\mathrm{mV}$, millivolts; $\mathrm{CaCO}_{3}$, calcium carbonate; --, not determined or not applicable; <, less than; $\mathrm{M}^{*}$, presence of material verified, but not quantified; $\mathrm{E}^{* *}$, estimated]

\begin{tabular}{|c|c|c|c|c|c|c|c|c|c|c|c|c|}
\hline $\begin{array}{c}\text { Date of } \\
\text { sample } \\
\text { collection } \\
\text { (month/day/ } \\
\text { year) }\end{array}$ & $\begin{array}{c}\text { Sample } \\
\text { start } \\
\text { time }\end{array}$ & $\begin{array}{l}\text { Dissolved } \\
\text { oxygen } \\
\text { (mg/L) }\end{array}$ & $\begin{array}{c}\text { pH, field } \\
\text { (standard } \\
\text { units) }\end{array}$ & $\begin{array}{c}\text { Specific } \\
\text { conductance } \\
(\mu \mathrm{S} / \mathrm{cm})\end{array}$ & $\begin{array}{c}\text { Water } \\
\text { temperature } \\
\left({ }^{\circ} \mathrm{C}\right)\end{array}$ & $\begin{array}{c}\text { Turbdity, } \\
\text { detection } \\
\text { angle } 90+/-30 \\
\text { degrees } \\
\text { (NTU) }\end{array}$ & $\begin{array}{l}\text { Turbidity, detectors } \\
\text { at multiple angles } \\
\text { including } \\
90+/-30 \text { degrees, } \\
\text { radiometric correction } \\
\text { (NTRU) }\end{array}$ & $\begin{array}{c}\text { Oxidation- } \\
\text { reduction (redox) } \\
\text { potential } \\
\text { (mV relative to the } \\
\text { standard hydrogen } \\
\text { electrode) }\end{array}$ & $\begin{array}{l}\text { Dissolved } \\
\text { solids } \\
\text { (mg/L) }\end{array}$ & $\begin{array}{c}\text { Hardness } \\
\text { as } \mathrm{CaCO}_{3} \\
(\mathrm{mg} / \mathrm{L})\end{array}$ & $\begin{array}{l}\text { Suspended } \\
\text { solids } \\
\text { (mg/L) }\end{array}$ & $\begin{array}{c}\text { Alkalinity } \\
\text { as } \mathrm{CaCO}_{3} \\
\text { (mg/L) }\end{array}$ \\
\hline \multicolumn{13}{|c|}{ RB1-PMS deep-Continued } \\
\hline $2 / 12 / 2009$ & 1041 & 0.7 & 7.0 & 549 & 14.9 & -- & -- & -- & -- & -- & -- & -- \\
\hline $2 / 12 / 2009$ & 1042 & 0.6 & 7.0 & 571 & 15.0 & -- & -- & -- & -- & -- & -- & -- \\
\hline $2 / 12 / 2009$ & 1043 & 0.6 & 7.0 & 574 & 15.0 & -- & -- & -- & -- & -- & -- & -- \\
\hline $2 / 12 / 2009$ & 1044 & 0.5 & 7.0 & 572 & 15.0 & -- & -- & -- & -- & -- & -- & -- \\
\hline $2 / 12 / 2009$ & 1045 & 0.6 & 7.0 & 571 & 15.0 & -- & -- & -- & -- & -- & -- & -- \\
\hline $2 / 12 / 2009$ & 1046 & 0.5 & 7.0 & 570 & 15.0 & -- & -- & -- & -- & -- & -- & -- \\
\hline $2 / 12 / 2009$ & 1047 & 0.5 & 7.0 & 570 & 15.0 & -- & -- & -- & -- & -- & -- & -- \\
\hline $2 / 12 / 2009$ & 1048 & 0.5 & 7.0 & 570 & 15.0 & -- & -- & -- & -- & -- & -- & -- \\
\hline $2 / 12 / 2009$ & 1049 & 0.5 & 7.0 & 570 & 15.0 & -- & -- & -- & -- & -- & -- & -- \\
\hline $2 / 12 / 2009$ & 1050 & 0.5 & 7.0 & 571 & 15.0 & -- & -- & -- & -- & -- & -- & -- \\
\hline $2 / 12 / 2009$ & 1051 & 0.5 & 7.0 & 571 & 15.0 & -- & -- & -- & -- & -- & -- & -- \\
\hline $2 / 12 / 2009$ & 1052 & 0.5 & 7.0 & 573 & 15.0 & -- & -- & -- & -- & -- & -- & -- \\
\hline $2 / 12 / 2009$ & 1053 & 0.5 & 7.0 & 570 & 15.0 & -- & -- & -- & -- & -- & -- & -- \\
\hline $2 / 12 / 2009$ & 1054 & 0.5 & 7.0 & 570 & 15.0 & -- & -- & -- & -- & -- & -- & -- \\
\hline $2 / 12 / 2009$ & 1055 & 0.5 & 7.0 & 570 & 15.0 & -- & -- & -- & -- & -- & -- & -- \\
\hline $3 / 9 / 2009$ & 1048 & 3.0 & 6.9 & 577 & 11.3 & -- & -- & -- & -- & -- & -- & -- \\
\hline $3 / 9 / 2009$ & 1049 & 1.8 & 6.9 & 576 & 12.0 & -- & -- & -- & -- & -- & -- & -- \\
\hline $3 / 9 / 2009$ & 1050 & 1.5 & 6.9 & 573 & 13.5 & -- & -- & -- & -- & -- & -- & -- \\
\hline $3 / 9 / 2009$ & 1051 & 1.1 & 6.9 & 555 & 14.1 & -- & -- & -- & -- & -- & -- & -- \\
\hline $3 / 9 / 2009$ & 1052 & 0.7 & 7.0 & 547 & 14.6 & -- & -- & -- & -- & -- & -- & -- \\
\hline $3 / 9 / 2009$ & 1053 & 0.3 & 7.1 & 583 & 14.6 & -- & -- & -- & -- & -- & -- & -- \\
\hline $3 / 9 / 2009$ & 1054 & 0.3 & 7.1 & 586 & 14.8 & -- & -- & -- & -- & -- & -- & -- \\
\hline $3 / 9 / 2009$ & 1055 & 0.3 & 7.1 & 581 & 14.8 & -- & -- & -- & -- & -- & -- & -- \\
\hline $3 / 9 / 2009$ & 1056 & 0.3 & 7.1 & 581 & 14.8 & -- & -- & -- & -- & -- & -- & -- \\
\hline $3 / 9 / 2009$ & 1057 & 0.3 & 7.1 & 580 & 14.8 & -- & -- & -- & -- & -- & -- & -- \\
\hline $3 / 9 / 2009$ & 1058 & 0.3 & 7.1 & 580 & 14.8 & -- & -- & -- & -- & -- & -- & -- \\
\hline $3 / 9 / 2009$ & 1059 & 0.3 & 7.1 & 581 & 14.8 & -- & -- & -- & -- & -- & -- & -- \\
\hline $3 / 9 / 2009$ & 1100 & 0.3 & 7.1 & 581 & 14.8 & -- & -- & -- & -- & -- & -- & -- \\
\hline $3 / 9 / 2009$ & 1101 & 0.2 & 7.1 & 582 & 14.8 & -- & -- & -- & -- & -- & -- & -- \\
\hline $3 / 9 / 2009$ & 1102 & 0.2 & 7.1 & 582 & 14.8 & -- & -- & -- & -- & -- & -- & -- \\
\hline $3 / 9 / 2009$ & 1103 & 0.2 & 7.1 & 582 & 14.8 & -- & -- & -- & -- & -- & -- & -- \\
\hline $3 / 9 / 2009$ & 1104 & 0.2 & 7.1 & 583 & 14.8 & -- & -- & -- & -- & -- & -- & -- \\
\hline
\end{tabular}


Table 5. Summary of physical property data from water samples collected as part of the Equus Beds Experimental Passive Recharge Project at RB1, 2009-2010.-Continued [mg/L, milligrams per liter; $\mu \mathrm{S} / \mathrm{cm}$, microsiemens per centimeter at 25 degrees Celsius; ${ }^{\circ} \mathrm{C}$, degrees Celsius; +/-, plus or minus; NTU, nephelometric turbidity units; NTRU, nephelometric turbidity ratiometric units; $\mathrm{mV}$, millivolts; $\mathrm{CaCO}_{3}$, calcium carbonate; --, not determined or not applicable; <, less than; $\mathrm{M}^{*}$, presence of material verified, but not quantified; $\mathrm{E}^{* *}$, estimated]

\begin{tabular}{|c|c|c|c|c|c|c|c|c|c|c|c|c|}
\hline $\begin{array}{c}\text { Date of } \\
\text { sample } \\
\text { collection } \\
\text { (month/day/ } \\
\text { year) }\end{array}$ & $\begin{array}{c}\text { Sample } \\
\text { start } \\
\text { time }\end{array}$ & $\begin{array}{l}\text { Dissolved } \\
\text { oxygen } \\
\text { (mg/L) }\end{array}$ & $\begin{array}{l}\text { pH, field } \\
\text { (standard } \\
\text { units) }\end{array}$ & $\begin{array}{c}\text { Specific } \\
\text { conductance } \\
\text { ( } \mathrm{\mu S} / \mathrm{cm})\end{array}$ & $\begin{array}{c}\text { Water } \\
\text { temperature } \\
\left({ }^{\circ} \mathrm{C}\right)\end{array}$ & $\begin{array}{c}\text { Turbdity, } \\
\text { detection } \\
\text { angle } 90+/-30 \\
\text { degrees } \\
\text { (NTU) }\end{array}$ & $\begin{array}{l}\text { Turbidity, detectors } \\
\text { at multiple angles } \\
\text { including } \\
90+/-30 \text { degrees, } \\
\text { radiometric correction } \\
\text { (NTRU) }\end{array}$ & $\begin{array}{c}\text { Oxidation- } \\
\text { reduction (redox) } \\
\text { potential } \\
\text { (mV relative to the } \\
\text { standard hydrogen } \\
\text { electrode) }\end{array}$ & $\begin{array}{l}\text { Dissolved } \\
\text { solids } \\
\text { (mg/L) }\end{array}$ & $\begin{array}{c}\text { Hardness } \\
\text { as } \mathrm{CaCO}_{3} \\
(\mathrm{mg} / \mathrm{L})\end{array}$ & $\begin{array}{l}\text { Suspended } \\
\text { solids } \\
\text { (mg/L) }\end{array}$ & $\begin{array}{c}\text { Alkalinity } \\
\text { as } \mathrm{CaCO}_{3} \\
\text { (mg/L) }\end{array}$ \\
\hline \multicolumn{13}{|c|}{ RB1-PMS deep-Continued } \\
\hline $3 / 9 / 2009$ & 1105 & 0.2 & 7.1 & 589 & 14.8 & -- & -- & -- & -- & -- & -- & -- \\
\hline $3 / 26 / 2009$ & 1240 & 3.8 & 6.8 & 454 & 13.9 & -- & 3.8 & 380 & -- & -- & -- & -- \\
\hline $3 / 26 / 2009$ & 1241 & -- & -- & -- & -- & -- & -- & -- & 269 & 160 & $<4$ & 149 \\
\hline $3 / 26 / 2009$ & 1245 & 3.8 & 6.8 & 454 & 13.9 & -- & 3.8 & 380 & -- & -- & -- & -- \\
\hline $4 / 4 / 2009$ & 1130 & 3.5 & 6.8 & 491 & 13.9 & -- & 1.4 & 440 & -- & -- & -- & -- \\
\hline 4/4/2009 & 1131 & -- & -- & -- & -- & -- & -- & -- & 453 & 170 & $<4$ & 135 \\
\hline 4/4/2009 & 1135 & 3.5 & 6.8 & 491 & 13.9 & -- & 1.4 & 440 & -- & -- & -- & -- \\
\hline 4/8/2009 & 1130 & 6.4 & 6.8 & 625 & 12.8 & -- & 1.0 & 420 & -- & -- & -- & -- \\
\hline 4/8/2009 & 1131 & -- & -- & -- & -- & -- & -- & -- & 374 & 190 & $<4$ & 115 \\
\hline 4/8/2009 & 1135 & 6.4 & 6.8 & 625 & 12.8 & -- & 1.0 & 420 & -- & -- & -- & -- \\
\hline $4 / 15 / 2009$ & 1215 & 5.1 & 7.0 & 592 & 12.9 & -- & 1.1 & 340 & -- & -- & -- & -- \\
\hline $4 / 15 / 2009$ & 1216 & -- & -- & -- & -- & -- & -- & -- & 351 & 170 & $<4$ & 120 \\
\hline $4 / 15 / 2009$ & 1217 & -- & -- & -- & -- & -- & -- & -- & -- & -- & -- & -- \\
\hline $4 / 18 / 2009$ & 1145 & 5.3 & 7.1 & 668 & 13.3 & -- & 0.4 & 300 & -- & -- & -- & -- \\
\hline $4 / 18 / 2009$ & 1146 & -- & -- & -- & -- & -- & -- & -- & 400 & 190 & $<4$ & 117 \\
\hline $5 / 6 / 2009$ & 1140 & 3.3 & 6.7 & 466 & 15.0 & -- & 1.2 & 370 & -- & -- & -- & -- \\
\hline $5 / 6 / 2009$ & 1141 & -- & -- & -- & -- & -- & -- & -- & 272 & 140 & $<4$ & 101 \\
\hline $5 / 6 / 2009$ & 1145 & 3.3 & 6.7 & 466 & 15.0 & -- & 1.2 & 370 & -- & -- & -- & -- \\
\hline $5 / 20 / 2009$ & 1150 & 1.3 & 6.8 & 726 & 15.4 & -- & 0.4 & 300 & -- & -- & -- & -- \\
\hline $5 / 20 / 2009$ & 1151 & -- & -- & -- & -- & -- & -- & -- & 296 & 160 & $<4$ & 123 \\
\hline $5 / 20 / 2009$ & 1155 & 1.3 & 6.8 & 726 & 15.4 & -- & 0.4 & 300 & -- & -- & -- & -- \\
\hline 7/8/2009 & 1005 & 0.2 & 7.0 & 716 & 15.9 & -- & 1.1 & 310 & -- & -- & -- & -- \\
\hline $7 / 8 / 2009$ & 1006 & -- & -- & -- & -- & -- & -- & -- & 423 & 240 & $<4$ & 168 \\
\hline 7/8/2009 & 1015 & 0.2 & 7.0 & 716 & 15.9 & -- & 1.1 & 310 & -- & -- & -- & -- \\
\hline $7 / 13 / 2009$ & 1140 & 0.4 & 6.9 & 801 & 16.0 & -- & 3.2 & 420 & -- & -- & -- & -- \\
\hline 7/13/2009 & 1141 & -- & -- & -- & -- & -- & -- & -- & 455 & 270 & $<4$ & 182 \\
\hline $7 / 13 / 2009$ & 1145 & 0.4 & 6.9 & 801 & 16.0 & -- & 3.2 & 420 & -- & -- & -- & -- \\
\hline 7/20/2009 & 1200 & 0.5 & 7.0 & 927 & 16.1 & -- & 1.2 & 390 & -- & -- & -- & -- \\
\hline 7/20/2009 & 1201 & -- & -- & -- & -- & -- & -- & -- & 561 & 310 & $<4$ & 190 \\
\hline 7/20/2009 & 1210 & 0.5 & 7.0 & 927 & 16.1 & -- & 1.2 & 390 & -- & -- & -- & -- \\
\hline $8 / 18 / 2009$ & 1145 & 0.5 & 6.8 & 629 & 16.1 & -- & 0.8 & 420 & -- & -- & -- & -- \\
\hline $8 / 18 / 2009$ & 1146 & -- & -- & -- & -- & -- & -- & -- & 357 & 210 & $<4$ & 146 \\
\hline
\end{tabular}


$\left[\mathrm{mg} / \mathrm{L}\right.$, milligrams per liter; $\mu \mathrm{S} / \mathrm{cm}$, microsiemens per centimeter at 25 degrees Celsius; ${ }^{\circ} \mathrm{C}$, degrees Celsius; +/-, plus or minus; NTU, nephelometric turbidity units; NTRU, nephelometric turbidity ratiometric units; $\mathrm{mV}$, millivolts; $\mathrm{CaCO}_{3}$, calcium carbonate; --, not determined or not applicable; <, less than; $\mathrm{M}^{*}$, presence of material verified, but not quantified; $\mathrm{E}^{* *}$, estimated]

\begin{tabular}{|c|c|c|c|c|c|c|c|c|c|c|c|c|}
\hline $\begin{array}{c}\text { Date of } \\
\text { sample } \\
\text { collection } \\
\text { (month/day/ } \\
\text { year) }\end{array}$ & $\begin{array}{c}\text { Sample } \\
\text { start } \\
\text { time }\end{array}$ & $\begin{array}{l}\text { Dissolved } \\
\text { oxygen } \\
\text { (mg/L) }\end{array}$ & $\begin{array}{c}\text { pH, field } \\
\text { (standard } \\
\text { units) }\end{array}$ & $\begin{array}{c}\text { Specific } \\
\text { conductance } \\
(\mu \mathrm{S} / \mathrm{cm})\end{array}$ & $\begin{array}{c}\text { Water } \\
\text { temperature } \\
\left({ }^{\circ} \mathrm{C}\right)\end{array}$ & $\begin{array}{c}\text { Turbdity, } \\
\text { detection } \\
\text { angle } 90+/-30 \\
\text { degrees } \\
\text { (NTU) }\end{array}$ & $\begin{array}{l}\text { Turbidity, detectors } \\
\text { at multiple angles } \\
\text { including } \\
90+/-30 \text { degrees, } \\
\text { radiometric correction } \\
\text { (NTRU) }\end{array}$ & $\begin{array}{c}\text { Oxidation- } \\
\text { reduction (redox) } \\
\text { potential } \\
\text { (mV relative to the } \\
\text { standard hydrogen } \\
\text { electrode) }\end{array}$ & $\begin{array}{l}\text { Dissolved } \\
\text { solids } \\
\text { (mg/L) }\end{array}$ & $\begin{array}{c}\text { Hardness } \\
\text { as } \mathrm{CaCO}_{3} \\
(\mathrm{mg} / \mathrm{L})\end{array}$ & $\begin{array}{l}\text { Suspended } \\
\text { solids } \\
\text { (mg/L) }\end{array}$ & $\begin{array}{c}\text { Alkalinity } \\
\text { as } \mathrm{CaCO}_{3} \\
\text { (mg/L) }\end{array}$ \\
\hline \multicolumn{13}{|c|}{ RB1-PMS deep-Continued } \\
\hline $8 / 18 / 2009$ & 1150 & 0.5 & 6.8 & 629 & 16.1 & -- & 0.8 & 420 & -- & -- & -- & -- \\
\hline $11 / 17 / 2009$ & 1120 & 0.3 & 6.9 & 578 & 15.1 & -- & 3.0 & 360 & -- & -- & -- & -- \\
\hline $11 / 17 / 2009$ & 1121 & -- & -- & -- & -- & -- & -- & -- & 346 & 190 & $<4$ & 132 \\
\hline $11 / 17 / 2009$ & 1125 & 0.3 & 6.9 & 578 & 15.1 & -- & 3.0 & 360 & -- & -- & -- & -- \\
\hline $3 / 2 / 2010$ & 1255 & M & 7.0 & 709 & 14.8 & -- & 0.8 & 360 & -- & -- & -- & -- \\
\hline $3 / 2 / 2010$ & 1256 & -- & -- & -- & -- & -- & -- & -- & 373 & 200 & $<10$ & 138 \\
\hline $3 / 2 / 2010$ & 1300 & $\mathrm{M}$ & 7.0 & 709 & 14.8 & -- & 0.8 & 360 & -- & -- & -- & -- \\
\hline $3 / 22 / 2010$ & 1025 & 0.3 & 6.9 & 611 & 14.6 & -- & 1.1 & 400 & -- & -- & -- & -- \\
\hline $3 / 22 / 2010$ & 1026 & -- & -- & -- & -- & -- & -- & -- & 363 & 200 & $<10$ & 140 \\
\hline $3 / 22 / 2010$ & 1030 & 0.3 & 6.9 & 611 & 14.6 & -- & 1.1 & 400 & -- & -- & -- & -- \\
\hline \multicolumn{13}{|c|}{ RB1-P shallow } \\
\hline $1 / 21 / 2009$ & 1500 & 1.9 & 6.6 & 583 & 13.6 & -- & 1.1 & 410 & -- & -- & -- & -- \\
\hline $1 / 21 / 2009$ & 1501 & -- & -- & -- & -- & -- & -- & -- & 359 & 190 & $<4$ & 136 \\
\hline $2 / 3 / 2009$ & 1015 & 5.3 & 6.6 & 674 & 7.2 & -- & 0.4 & 440 & -- & -- & -- & -- \\
\hline $2 / 3 / 2009$ & 1016 & -- & -- & -- & -- & -- & -- & -- & 403 & 210 & $<4$ & 172 \\
\hline $2 / 3 / 2009$ & 1017 & -- & -- & -- & -- & -- & -- & -- & -- & -- & -- & -- \\
\hline $2 / 3 / 2009$ & 1020 & 5.3 & 6.6 & 674 & 7.2 & -- & 0.4 & 440 & -- & -- & -- & -- \\
\hline $2 / 3 / 2009$ & 1021 & -- & -- & -- & -- & -- & -- & -- & 418 & 210 & $<4$ & 174 \\
\hline $3 / 25 / 2009$ & 1035 & 5.3 & 6.7 & 561 & 12.3 & -- & 0.5 & 400 & -- & -- & -- & -- \\
\hline $3 / 25 / 2009$ & 1036 & -- & -- & -- & -- & -- & -- & -- & 351 & 190 & $<4$ & 152 \\
\hline $3 / 25 / 2009$ & 1040 & 5.3 & 6.7 & 561 & 12.3 & -- & 0.5 & 400 & -- & -- & -- & -- \\
\hline $4 / 4 / 2009$ & 1310 & 10.4 & 6.8 & 604 & 12.3 & -- & 0.9 & 480 & -- & -- & -- & -- \\
\hline $4 / 4 / 2009$ & 1311 & -- & -- & -- & -- & -- & -- & -- & 369 & 190 & $<4$ & 67 \\
\hline $4 / 4 / 2009$ & 1315 & 10.4 & 6.8 & 604 & 12.3 & -- & 0.9 & 480 & -- & -- & -- & -- \\
\hline $4 / 4 / 2009$ & 1316 & -- & -- & -- & -- & -- & -- & -- & 372 & 180 & $<4$ & 65 \\
\hline 4/7/2009 & 1155 & 10.7 & 7.4 & 722 & 7.9 & -- & 1.1 & 430 & -- & -- & -- & -- \\
\hline 4/7/2009 & 1156 & -- & -- & -- & -- & -- & -- & -- & 423 & 190 & $<4$ & 96 \\
\hline 4/7/2009 & 1200 & 10.7 & 7.4 & 722 & 7.9 & -- & 1.1 & 430 & -- & -- & -- & -- \\
\hline $4 / 15 / 2009$ & 1040 & 10.3 & 7.2 & 729 & 12.7 & -- & 1.3 & 400 & -- & -- & -- & -- \\
\hline $4 / 15 / 2009$ & 1041 & -- & -- & -- & -- & -- & -- & -- & 447 & 180 & $<4$ & 106 \\
\hline $4 / 18 / 2009$ & 1010 & 7.0 & 7.2 & 730 & 16.0 & -- & 1.5 & 350 & -- & -- & -- & -- \\
\hline $4 / 18 / 2009$ & 1011 & -- & -- & -- & -- & -- & -- & -- & 454 & 190 & $<4$ & 102 \\
\hline
\end{tabular}


Table 5. Summary of physical property data from water samples collected as part of the Equus Beds Experimental Passive Recharge Project at RB1, 2009-2010.-Continued [mg/L, milligrams per liter; $\mu \mathrm{S} / \mathrm{cm}$, microsiemens per centimeter at 25 degrees Celsius; ${ }^{\circ} \mathrm{C}$, degrees Celsius; $+/-$, plus or minus; NTU, nephelometric turbidity units; NTRU, nephelometric turbidity ratiometric units; $\mathrm{mV}$, millivolts; $\mathrm{CaCO}_{3}$, calcium carbonate; --, not determined or not applicable; <, less than; $\mathrm{M}^{*}$, presence of material verified, but not quantified; $\mathrm{E}^{* *}$, estimated]

\begin{tabular}{|c|c|c|c|c|c|c|c|c|c|c|c|c|}
\hline $\begin{array}{c}\text { Date of } \\
\text { sample } \\
\text { collection } \\
\text { (month/day/ } \\
\text { year) }\end{array}$ & $\begin{array}{l}\text { Sample } \\
\text { start } \\
\text { time }\end{array}$ & $\begin{array}{l}\text { Dissolved } \\
\text { oxygen } \\
\text { (mg/L) }\end{array}$ & $\begin{array}{c}\mathrm{pH} \text {, field } \\
\text { (standard } \\
\text { units) }\end{array}$ & $\begin{array}{c}\text { Specific } \\
\text { conductance } \\
(\mu \mathrm{S} / \mathrm{cm})\end{array}$ & $\begin{array}{c}\text { Water } \\
\text { temperature } \\
\left({ }^{\circ} \mathrm{C}\right)\end{array}$ & $\begin{array}{l}\text { Turbdity, } \\
\text { detection } \\
\text { angle } 90+/-30 \\
\text { degrees } \\
\text { (NTU) }\end{array}$ & $\begin{array}{l}\text { Turbidity, detectors } \\
\text { at multiple angles } \\
\text { including } \\
90+/-30 \text { degrees, } \\
\text { radiometric correction } \\
\text { (NTRU) }\end{array}$ & $\begin{array}{c}\text { Oxidation- } \\
\text { reduction (redox) } \\
\text { potential } \\
\text { ( } \mathrm{mV} \text { relative to the } \\
\text { standard hydrogen } \\
\text { electrode) }\end{array}$ & $\begin{array}{l}\text { Dissolved } \\
\text { solids } \\
\text { (mg/L) }\end{array}$ & $\begin{array}{c}\text { Hardness } \\
\text { as } \mathrm{CaCO}_{3} \\
(\mathrm{mg} / \mathrm{L})\end{array}$ & $\begin{array}{l}\text { Suspended } \\
\text { solids } \\
(\mathrm{mg} / \mathrm{L})\end{array}$ & $\begin{array}{c}\text { Alkalinity } \\
\text { as CaCo } \\
(\mathrm{mg} / \mathrm{L})^{3}\end{array}$ \\
\hline \multicolumn{13}{|c|}{ RB1-P shallow-Continued } \\
\hline 5/4/2009 & 1225 & 6.3 & 6.9 & 406 & 17.1 & -- & 1.2 & 370 & -- & -- & -- & -- \\
\hline $5 / 4 / 2009$ & 1226 & -- & -- & -- & -- & -- & -- & -- & 237 & 110 & $<4$ & 60 \\
\hline $5 / 4 / 2009$ & 1230 & 6.3 & 6.9 & 406 & 17.1 & -- & 1.2 & 370 & -- & -- & -- & -- \\
\hline $5 / 19 / 2009$ & 1145 & 3.5 & 6.8 & 595 & 17.4 & -- & 1.2 & 380 & -- & -- & -- & -- \\
\hline $5 / 19 / 2009$ & 1146 & -- & -- & -- & -- & -- & -- & -- & 363 & 180 & $<4$ & 157 \\
\hline $5 / 19 / 2009$ & 1150 & 3.5 & 6.8 & 595 & 17.4 & -- & 1.2 & 380 & -- & -- & -- & -- \\
\hline $8 / 17 / 2009$ & 1050 & 0.3 & 6.9 & 657 & 15.8 & -- & 1.3 & 290 & -- & -- & -- & -- \\
\hline $8 / 17 / 2009$ & 1051 & -- & -- & -- & -- & -- & -- & -- & 390 & 230 & $<4$ & 134 \\
\hline $8 / 17 / 2009$ & 1055 & 0.3 & 6.9 & 657 & 15.8 & -- & 1.3 & 290 & -- & -- & -- & -- \\
\hline $11 / 16 / 2009$ & 1015 & 0.2 & 6.9 & 624 & 14.6 & -- & 1.8 & 270 & -- & -- & -- & -- \\
\hline $11 / 16 / 2009$ & 1016 & -- & -- & -- & -- & -- & -- & -- & 378 & 210 & $<4$ & 128 \\
\hline $11 / 16 / 2009$ & 1017 & -- & -- & -- & -- & -- & -- & -- & -- & -- & -- & -- \\
\hline $11 / 16 / 2009$ & 1020 & 0.2 & 6.9 & 624 & 14.6 & -- & 1.8 & 270 & -- & -- & -- & -- \\
\hline $3 / 3 / 2010$ & 1020 & -- & 7.0 & 733 & 15.2 & -- & 4.6 & 330 & -- & -- & -- & -- \\
\hline $3 / 3 / 2010$ & 1021 & -- & -- & -- & -- & -- & -- & -- & 373 & 200 & $<10$ & 130 \\
\hline $3 / 3 / 2010$ & 1025 & -- & 7.0 & 733 & 15.2 & -- & 4.6 & 330 & -- & -- & -- & -- \\
\hline \multicolumn{13}{|c|}{ RB1-P deep } \\
\hline $2 / 3 / 2009$ & 1150 & 4.9 & 6.6 & 670 & 9.1 & -- & 12.0 & 430 & -- & -- & -- & -- \\
\hline $2 / 3 / 2009$ & 1151 & -- & -- & -- & -- & -- & -- & -- & 417 & 210 & 6 & 178 \\
\hline $2 / 12 / 2009$ & 1240 & 5.1 & 6.9 & 647 & 8.1 & -- & -- & -- & -- & -- & -- & -- \\
\hline $2 / 12 / 2009$ & 1242 & 4.9 & 6.8 & 657 & 8.2 & -- & -- & -- & -- & -- & -- & -- \\
\hline $2 / 12 / 2009$ & 1244 & 4.9 & 6.8 & 657 & 8.3 & -- & -- & -- & -- & -- & -- & -- \\
\hline $2 / 12 / 2009$ & 1245 & 4.7 & 6.8 & 653 & 8.6 & -- & -- & -- & -- & -- & -- & -- \\
\hline $2 / 12 / 2009$ & 1246 & 4.6 & 6.8 & 649 & 8.8 & -- & -- & -- & -- & -- & -- & -- \\
\hline $2 / 12 / 2009$ & 1247 & 4.3 & 6.8 & 642 & 9.2 & -- & -- & -- & -- & -- & -- & -- \\
\hline $2 / 12 / 2009$ & 1248 & 4.0 & 6.8 & 640 & 9.3 & -- & -- & -- & -- & -- & -- & -- \\
\hline $2 / 12 / 2009$ & 1249 & 3.6 & 6.8 & 636 & 9.8 & -- & -- & -- & -- & -- & -- & -- \\
\hline $2 / 12 / 2009$ & 1250 & 3.3 & 6.8 & 635 & 10.0 & -- & -- & -- & -- & -- & -- & -- \\
\hline $2 / 12 / 2009$ & 1251 & 3.3 & 6.8 & 636 & 10.3 & -- & -- & -- & -- & -- & -- & -- \\
\hline $2 / 12 / 2009$ & 1252 & 3.5 & 6.8 & 639 & 10.3 & -- & -- & -- & -- & -- & -- & -- \\
\hline $2 / 12 / 2009$ & 1253 & 5.0 & 6.9 & 655 & 8.5 & -- & -- & -- & -- & -- & -- & -- \\
\hline $2 / 12 / 2009$ & 1254 & 5.1 & 6.9 & 654 & 8.7 & -- & -- & -- & -- & -- & -- & -- \\
\hline
\end{tabular}


$\left[\mathrm{mg} / \mathrm{L}\right.$, milligrams per liter; $\mu \mathrm{S} / \mathrm{cm}$, microsiemens per centimeter at 25 degrees Celsius; ${ }^{\circ} \mathrm{C}$, degrees Celsius; +/-, plus or minus; NTU, nephelometric turbidity units; NTRU, nephelometric turbidity ratiometric units; $\mathrm{mV}$, millivolts; $\mathrm{CaCO}_{3}$, calcium carbonate; --, not determined or not applicable; <, less than; $\mathrm{M}^{*}$, presence of material verified, but not quantified; $\mathrm{E}^{* *}$, estimated]

\begin{tabular}{|c|c|c|c|c|c|c|c|c|c|c|c|c|}
\hline $\begin{array}{c}\text { Date of } \\
\text { sample } \\
\text { collection } \\
\text { (month/day/ } \\
\text { year) }\end{array}$ & $\begin{array}{c}\text { Sample } \\
\text { start } \\
\text { time }\end{array}$ & $\begin{array}{c}\text { Dissolved } \\
\text { oxygen } \\
\text { (mg/L) }\end{array}$ & $\begin{array}{c}\text { pH, field } \\
\text { (standard } \\
\text { units) }\end{array}$ & $\begin{array}{c}\text { Specific } \\
\text { conductance } \\
(\mu \mathrm{S} / \mathrm{cm})\end{array}$ & $\begin{array}{c}\text { Water } \\
\text { temperature } \\
\left({ }^{\circ} \mathrm{C}\right)\end{array}$ & $\begin{array}{c}\text { Turbdity, } \\
\text { detection } \\
\text { angle } 90+/-30 \\
\text { degrees } \\
\text { (NTU) }\end{array}$ & $\begin{array}{l}\text { Turbidity, detectors } \\
\text { at multiple angles } \\
\text { including } \\
90+/-30 \text { degrees, } \\
\text { radiometric correction } \\
\text { (NTRU) }\end{array}$ & $\begin{array}{c}\text { Oxidation- } \\
\text { reduction (redox) } \\
\text { potential } \\
\text { (mV relative to the } \\
\text { standard hydrogen } \\
\text { electrode) }\end{array}$ & $\begin{array}{l}\text { Dissolved } \\
\text { solids } \\
\text { (mg/L) }\end{array}$ & $\begin{array}{c}\text { Hardness } \\
\text { as } \mathrm{CaCO}_{3} \\
(\mathrm{mg} / \mathrm{L})\end{array}$ & $\begin{array}{l}\text { Suspended } \\
\text { solids } \\
\text { (mg/L) }\end{array}$ & $\begin{array}{c}\text { Alkalinity } \\
\text { as } \mathrm{CaCO}_{3} \\
\text { (mg/L) }\end{array}$ \\
\hline \multicolumn{13}{|c|}{ RB1-P deep-Continued } \\
\hline $2 / 12 / 2009$ & 1255 & 5.1 & 6.9 & 653 & 8.8 & -- & -- & -- & -- & -- & -- & -- \\
\hline $2 / 12 / 2009$ & 1256 & 5.1 & 6.9 & 653 & 8.9 & -- & -- & -- & -- & -- & -- & -- \\
\hline $2 / 12 / 2009$ & 1257 & 5.1 & 6.9 & 652 & 9.3 & -- & -- & -- & -- & -- & -- & -- \\
\hline $2 / 12 / 2009$ & 1258 & 5.2 & 6.9 & 652 & 9.9 & -- & -- & -- & -- & -- & -- & -- \\
\hline $2 / 12 / 2009$ & 1259 & 5.2 & 6.9 & 650 & 10.9 & -- & -- & -- & -- & -- & -- & -- \\
\hline $2 / 12 / 2009$ & 1300 & 5.4 & 6.9 & 646 & 12.0 & -- & -- & -- & -- & -- & -- & -- \\
\hline $2 / 12 / 2009$ & 1301 & 5.5 & 7.0 & 641 & 12.8 & -- & -- & -- & -- & -- & -- & -- \\
\hline $2 / 12 / 2009$ & 1302 & 5.5 & 7.0 & 635 & 13.4 & -- & -- & -- & -- & -- & -- & -- \\
\hline $2 / 12 / 2009$ & 1303 & 5.6 & 7.0 & 629 & 13.7 & -- & -- & -- & -- & -- & -- & -- \\
\hline $2 / 12 / 2009$ & 1304 & 5.6 & 7.0 & 626 & 14.0 & -- & -- & -- & -- & -- & -- & -- \\
\hline $2 / 12 / 2009$ & 1305 & 5.4 & 7.0 & 630 & 14.2 & -- & -- & -- & -- & -- & -- & -- \\
\hline $3 / 9 / 2009$ & 1110 & 7.4 & 7.1 & 599 & 10.0 & -- & -- & -- & -- & -- & -- & -- \\
\hline $3 / 9 / 2009$ & 1111 & 7.3 & 7.1 & 619 & 9.9 & -- & -- & -- & -- & -- & -- & -- \\
\hline $3 / 9 / 2009$ & 1112 & 6.8 & 7.0 & 643 & 10.0 & -- & -- & -- & -- & -- & -- & -- \\
\hline $3 / 9 / 2009$ & 1113 & 6.7 & 7.0 & 650 & 10.1 & -- & -- & -- & -- & -- & -- & -- \\
\hline $3 / 9 / 2009$ & 1114 & 6.5 & 7.0 & 657 & 10.1 & -- & -- & -- & -- & -- & -- & -- \\
\hline $3 / 9 / 2009$ & 1115 & 6.2 & 7.0 & 667 & 10.0 & -- & -- & -- & -- & -- & -- & -- \\
\hline $3 / 9 / 2009$ & 1116 & 5.6 & 7.0 & 623 & 10.4 & -- & -- & -- & -- & -- & -- & -- \\
\hline $3 / 9 / 2009$ & 1117 & 5.4 & 7.0 & 610 & 10.5 & -- & -- & -- & -- & -- & -- & -- \\
\hline $3 / 9 / 2009$ & 1118 & 5.9 & 7.0 & 687 & 10.1 & -- & -- & -- & -- & -- & -- & -- \\
\hline $3 / 9 / 2009$ & 1119 & 6.0 & 7.0 & 684 & 10.2 & -- & -- & -- & -- & -- & -- & -- \\
\hline $3 / 9 / 2009$ & 1120 & 6.0 & 7.0 & 678 & 10.4 & -- & -- & -- & -- & -- & -- & -- \\
\hline $3 / 9 / 2009$ & 1121 & 6.1 & 7.0 & 668 & 10.8 & -- & -- & -- & -- & -- & -- & -- \\
\hline $3 / 9 / 2009$ & 1122 & 6.2 & 7.0 & 654 & 11.3 & -- & -- & -- & -- & -- & -- & -- \\
\hline $3 / 9 / 2009$ & 1123 & 6.3 & 7.0 & 631 & 12.1 & -- & -- & -- & -- & -- & -- & -- \\
\hline 3/9/2009 & 1124 & 6.4 & 7.0 & 609 & 12.7 & -- & -- & -- & -- & -- & -- & -- \\
\hline $3 / 9 / 2009$ & 1125 & 6.5 & 7.0 & 582 & 13.2 & -- & -- & -- & -- & -- & -- & -- \\
\hline 3/9/2009 & 1126 & 6.6 & 7.1 & 560 & 13.5 & -- & -- & -- & -- & -- & -- & -- \\
\hline $3 / 25 / 2009$ & 1205 & 5.3 & 6.7 & 558 & 12.5 & -- & 1.3 & 400 & -- & -- & -- & -- \\
\hline $3 / 25 / 2009$ & 1206 & -- & -- & -- & -- & -- & -- & -- & 351 & 190 & $<4$ & 150 \\
\hline $3 / 25 / 2009$ & 1210 & 5.3 & 6.7 & 558 & 12.5 & -- & 1.3 & 400 & -- & -- & -- & -- \\
\hline $4 / 4 / 2009$ & 1440 & 10.2 & 6.8 & 601 & 12.7 & -- & 1.6 & 450 & -- & -- & -- & -- \\
\hline
\end{tabular}


Table 5. Summary of physical property data from water samples collected as part of the Equus Beds Experimental Passive Recharge Project at RB1, 2009-2010.-Continued $\left[\mathrm{mg} / \mathrm{L}\right.$, milligrams per liter; $\mu \mathrm{S} / \mathrm{cm}$, microsiemens per centimeter at 25 degrees Celsius; ${ }^{\circ} \mathrm{C}$, degrees Celsius; +/-, plus or minus; NTU, nephelometric turbidity units; NTRU, nephelometric turbidity ratiometric units; $\mathrm{mV}$, millivolts; $\mathrm{CaCO}_{3}$, calcium carbonate; --, not determined or not applicable; <, less than; $\mathrm{M}^{*}$, presence of material verified, but not quantified; $\mathrm{E}^{* *}$, estimated]

\begin{tabular}{|c|c|c|c|c|c|c|c|c|c|c|c|c|}
\hline $\begin{array}{c}\text { Date of } \\
\text { sample } \\
\text { collection } \\
\text { (month/day/ } \\
\text { year) }\end{array}$ & $\begin{array}{c}\text { Sample } \\
\text { start } \\
\text { time }\end{array}$ & $\begin{array}{c}\text { Dissolved } \\
\text { oxygen } \\
\text { (mg/L) }\end{array}$ & $\begin{array}{c}\text { pH, field } \\
\text { (standard } \\
\text { units) }\end{array}$ & 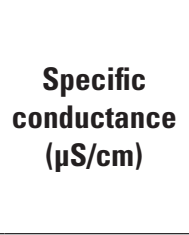 & $\begin{array}{c}\text { Water } \\
\text { temperature } \\
\left({ }^{\circ} \mathrm{C}\right)\end{array}$ & $\begin{array}{c}\text { Turbdity, } \\
\text { detection } \\
\text { angle } 90+/-30 \\
\text { degrees } \\
\text { (NTU) }\end{array}$ & $\begin{array}{l}\text { Turbidity, detectors } \\
\text { at multiple angles } \\
\text { including } \\
90+/-30 \text { degrees, } \\
\text { radiometric correction } \\
\text { (NTRU) }\end{array}$ & $\begin{array}{c}\text { Oxidation- } \\
\text { reduction (redox) } \\
\text { potential } \\
\text { (mV relative to the } \\
\text { standard hydrogen } \\
\text { electrode) }\end{array}$ & $\begin{array}{l}\text { Dissolved } \\
\text { solids } \\
\text { (mg/L) }\end{array}$ & $\begin{array}{c}\text { Hardness } \\
\text { as } \mathrm{CaCO}_{3} \\
(\mathrm{mg} / \mathrm{L})\end{array}$ & $\begin{array}{l}\text { Suspended } \\
\text { solids } \\
\text { (mg/L) }\end{array}$ & $\begin{array}{c}\text { Alkalinity } \\
\text { as } \mathrm{CaCO}_{3} \\
(\mathrm{mg} / \mathrm{L})\end{array}$ \\
\hline \multicolumn{13}{|c|}{ RB1-P deep-Continued } \\
\hline $4 / 4 / 2009$ & 1441 & -- & -- & -- & -- & -- & -- & -- & 354 & 190 & $<4$ & 68 \\
\hline $4 / 4 / 2009$ & 1445 & 10.2 & 6.8 & 601 & 12.7 & -- & 1.6 & 450 & -- & -- & -- & -- \\
\hline $4 / 7 / 2009$ & 1320 & 10.5 & 7.4 & 718 & 8.9 & -- & 1.5 & 430 & -- & -- & -- & -- \\
\hline 4/7/2009 & 1321 & -- & -- & -- & -- & -- & -- & -- & 437 & 190 & $<4$ & 94 \\
\hline 4/7/2009 & 1325 & 10.5 & 7.4 & 718 & 8.9 & -- & 1.5 & 430 & -- & -- & -- & -- \\
\hline $4 / 15 / 2009$ & 1210 & 10.4 & 7.2 & 726 & 13.2 & -- & 1.5 & 400 & -- & -- & -- & -- \\
\hline $4 / 15 / 2009$ & 1211 & -- & -- & -- & -- & -- & -- & -- & 437 & 180 & $<4$ & 112 \\
\hline $4 / 18 / 2009$ & 1130 & 7.0 & 7.2 & 734 & 16.2 & -- & 1.5 & 370 & -- & -- & -- & -- \\
\hline $4 / 18 / 2009$ & 1131 & -- & -- & -- & -- & -- & -- & -- & 448 & 190 & $<4$ & 102 \\
\hline $4 / 18 / 2009$ & 1132 & -- & -- & -- & -- & -- & -- & -- & -- & -- & -- & -- \\
\hline $5 / 4 / 2009$ & 1335 & 6.4 & 6.9 & 409 & 16.8 & -- & 2.5 & 370 & -- & -- & -- & -- \\
\hline $5 / 4 / 2009$ & 1336 & -- & -- & -- & -- & -- & -- & -- & 231 & 110 & $<4$ & 56 \\
\hline $5 / 4 / 2009$ & 1340 & 6.4 & 6.9 & 409 & 16.8 & -- & 2.5 & 370 & -- & -- & -- & -- \\
\hline $5 / 19 / 2009$ & 1300 & 3.5 & 6.8 & 598 & 17.1 & -- & 5.2 & 400 & -- & -- & -- & -- \\
\hline $5 / 19 / 2009$ & 1301 & -- & -- & -- & -- & -- & -- & -- & 363 & 180 & $<4$ & 156 \\
\hline $5 / 19 / 2009$ & 1302 & -- & -- & -- & -- & -- & -- & -- & -- & -- & -- & -- \\
\hline $5 / 19 / 2009$ & 1305 & 3.5 & 6.8 & 598 & 17.1 & -- & 5.2 & 400 & -- & -- & -- & -- \\
\hline 7/9/2009 & 1055 & 3.8 & 7.3 & 675 & 15.6 & -- & 1.3 & 480 & -- & -- & -- & -- \\
\hline $7 / 9 / 2009$ & 1056 & -- & -- & -- & -- & -- & -- & -- & 391 & 220 & $<4$ & 160 \\
\hline 7/9/2009 & 1100 & 3.8 & 7.3 & 675 & 15.6 & -- & 1.3 & 480 & -- & -- & -- & -- \\
\hline $7 / 13 / 2009$ & 1235 & 3.9 & 7.2 & 684 & 15.8 & -- & $<0.1$ & -- & -- & -- & -- & -- \\
\hline $7 / 13 / 2009$ & 1236 & -- & -- & -- & -- & -- & -- & -- & 400 & 230 & $<4$ & 166 \\
\hline $7 / 13 / 2009$ & 1240 & 3.9 & 7.2 & 684 & 15.8 & -- & $<0.1$ & -- & -- & -- & -- & -- \\
\hline $7 / 20 / 2009$ & 1000 & 6.4 & 7.7 & 650 & 15.2 & -- & -- & 430 & -- & -- & -- & -- \\
\hline $7 / 20 / 2009$ & 1001 & -- & -- & -- & -- & -- & -- & -- & 423 & 250 & $<4$ & 168 \\
\hline $7 / 20 / 2009$ & 1005 & 6.4 & 7.7 & 650 & 15.2 & -- & -- & 430 & -- & -- & -- & -- \\
\hline $8 / 12 / 2009$ & 1020 & 5.0 & 7.3 & 761 & 15.8 & -- & 1.1 & -- & -- & -- & -- & -- \\
\hline $8 / 12 / 2009$ & 1021 & -- & -- & -- & -- & -- & -- & -- & 441 & 270 & $<4$ & 170 \\
\hline $8 / 12 / 2009$ & 1025 & 5.0 & 7.3 & 761 & 15.8 & -- & 1.1 & -- & -- & -- & -- & -- \\
\hline $8 / 17 / 2009$ & 1210 & 0.1 & 6.9 & 668 & 15.7 & -- & 0.8 & 280 & -- & -- & -- & -- \\
\hline $8 / 17 / 2009$ & 1211 & -- & -- & -- & -- & -- & -- & -- & 398 & 230 & $<4$ & 135 \\
\hline $8 / 17 / 2009$ & 1215 & 0.1 & 6.9 & 668 & 15.7 & -- & 0.8 & 280 & -- & -- & -- & -- \\
\hline
\end{tabular}


$\left[\mathrm{mg} / \mathrm{L}\right.$, milligrams per liter; $\mu \mathrm{S} / \mathrm{cm}$, microsiemens per centimeter at 25 degrees Celsius; ${ }^{\circ} \mathrm{C}$, degrees Celsius; $+/$-, plus or minus; NTU, nephelometric turbidity units; NTRU, nephelometric turbidity ratiometric units; $\mathrm{mV}$, millivolts; $\mathrm{CaCO}_{3}$, calcium carbonate; --, not determined or not applicable; <, less than; $\mathrm{M}^{*}$, presence of material verified, but not quantified; $\mathrm{E}^{* *}$, estimated]

\begin{tabular}{|c|c|c|c|c|c|c|c|c|c|c|c|c|}
\hline $\begin{array}{c}\text { Date of } \\
\text { sample } \\
\text { collection } \\
\text { (month/day/ } \\
\text { year) }\end{array}$ & $\begin{array}{c}\text { Sample } \\
\text { start } \\
\text { time }\end{array}$ & $\begin{array}{c}\text { Dissolved } \\
\text { oxygen } \\
\text { (mg/L) }\end{array}$ & $\begin{array}{c}\text { pH, field } \\
\text { (standard } \\
\text { units) }\end{array}$ & 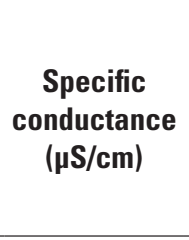 & $\begin{array}{c}\text { Water } \\
\text { temperature } \\
\left({ }^{\circ} \mathrm{C}\right)\end{array}$ & $\begin{array}{c}\text { Turbdity, } \\
\text { detection } \\
\text { angle } 90+/-30 \\
\text { degrees } \\
\text { (NTU) }\end{array}$ & $\begin{array}{l}\text { Turbidity, detectors } \\
\text { at multiple angles } \\
\text { including } \\
90+/-30 \text { degrees, } \\
\text { radiometric correction } \\
\text { (NTRU) }\end{array}$ & $\begin{array}{c}\text { Oxidation- } \\
\text { reduction (redox) } \\
\text { potential } \\
\text { (mV relative to the } \\
\text { standard hydrogen } \\
\text { electrode) } \\
\end{array}$ & $\begin{array}{l}\text { Dissolved } \\
\text { solids } \\
\text { (mg/L) }\end{array}$ & $\begin{array}{l}\text { Hardness } \\
\text { as } \mathrm{CaCO}_{3} \\
(\mathrm{mg} / \mathrm{L})\end{array}$ & $\begin{array}{l}\text { Suspended } \\
\text { solids } \\
\text { (mg/L) }\end{array}$ & $\begin{array}{c}\text { Alkalinity } \\
\text { as } \mathrm{CaCO}_{3} \\
(\mathrm{mg} / \mathrm{L})\end{array}$ \\
\hline \multicolumn{13}{|c|}{ RB1-P deep-Continued } \\
\hline $11 / 16 / 2009$ & 1125 & 0.2 & 6.9 & 668 & 14.4 & -- & 2.5 & 300 & -- & -- & -- & -- \\
\hline $11 / 16 / 2009$ & 1126 & -- & -- & -- & -- & -- & -- & -- & 402 & 230 & $<4$ & 132 \\
\hline $11 / 16 / 2009$ & 1130 & 0.2 & 6.9 & 668 & 14.4 & -- & 2.5 & 300 & -- & -- & -- & -- \\
\hline $3 / 3 / 2010$ & 1135 & -- & 7.0 & 784 & 15.4 & -- & 2.2 & 310 & -- & -- & -- & -- \\
\hline $3 / 3 / 2010$ & 1136 & -- & -- & -- & -- & -- & -- & -- & 391 & 220 & $<10$ & 130 \\
\hline $3 / 3 / 2010$ & 1140 & -- & 7.0 & 784 & 15.4 & -- & 2.2 & 310 & -- & -- & -- & -- \\
\hline \multicolumn{13}{|c|}{ RB1-TR } \\
\hline $3 / 26 / 2009$ & 1020 & 6.0 & 6.8 & 543 & 11.8 & -- & 1.2 & 410 & -- & -- & -- & -- \\
\hline $3 / 26 / 2009$ & 1021 & -- & -- & -- & -- & -- & -- & -- & 344 & 190 & $<4$ & 151 \\
\hline $3 / 26 / 2009$ & 1025 & 6.0 & 6.8 & 543 & 11.8 & -- & 1.2 & 410 & -- & -- & -- & -- \\
\hline 4/3/2009 & 1350 & 10.7 & 7.2 & 499 & 8.8 & -- & 2.8 & 480 & -- & -- & -- & -- \\
\hline 4/3/2009 & 1351 & -- & -- & -- & -- & -- & -- & -- & 312 & 180 & $<4$ & 70 \\
\hline 4/3/2009 & 1352 & -- & -- & -- & -- & -- & -- & -- & -- & -- & -- & -- \\
\hline 4/3/2009 & 1355 & 10.7 & 7.2 & 499 & 8.8 & -- & 2.8 & 480 & -- & -- & -- & -- \\
\hline 4/7/2009 & 1000 & 11.4 & 7.4 & 723 & 7.4 & -- & 1.2 & 420 & -- & -- & -- & -- \\
\hline 4/7/2009 & 1001 & -- & -- & -- & -- & -- & -- & -- & 429 & 190 & $<4$ & 94 \\
\hline 4/7/2009 & 1002 & -- & -- & -- & -- & -- & -- & -- & -- & -- & -- & -- \\
\hline 4/7/2009 & 1005 & 11.4 & 7.4 & 723 & 7.4 & -- & 1.2 & 420 & -- & -- & -- & -- \\
\hline 4/7/2009 & 1006 & -- & -- & -- & -- & -- & -- & -- & 428 & 190 & $<4$ & 94 \\
\hline $4 / 14 / 2009$ & 1131 & -- & -- & -- & -- & -- & -- & -- & 459 & 190 & $<4$ & 118 \\
\hline $4 / 14 / 2009$ & 1330 & 9.6 & 7.3 & 653 & 10.8 & -- & 1.5 & 380 & -- & -- & -- & -- \\
\hline $4 / 17 / 2009$ & 1250 & 7.5 & 7.1 & 742 & 16.5 & -- & 1.5 & 400 & -- & -- & -- & -- \\
\hline $4 / 17 / 2009$ & 1251 & -- & -- & -- & -- & -- & -- & -- & 449 & 200 & $<4$ & 111 \\
\hline $4 / 23 / 2009$ & 1121 & -- & -- & -- & -- & -- & -- & -- & 349 & 130 & 4 & 74 \\
\hline $4 / 23 / 2009$ & 1220 & 7.5 & 7.3 & 600 & 16.9 & -- & 8.1 & 360 & -- & -- & -- & -- \\
\hline $4 / 23 / 2009$ & 1222 & -- & -- & -- & -- & -- & -- & -- & -- & -- & -- & -- \\
\hline $4 / 27 / 2009$ & 1140 & 6.5 & 7.2 & 361 & 17.2 & -- & 20.0 & 360 & -- & -- & -- & -- \\
\hline $4 / 27 / 2009$ & 1141 & -- & -- & -- & -- & -- & -- & -- & 223 & 88 & 7 & 70 \\
\hline $4 / 27 / 2009$ & 1145 & 6.5 & 7.2 & 361 & 17.2 & -- & 20.0 & 360 & -- & -- & -- & -- \\
\hline $5 / 4 / 2009$ & 1055 & 6.6 & 7.0 & 407 & 16.4 & -- & 0.9 & 390 & -- & -- & -- & -- \\
\hline $5 / 4 / 2009$ & 1056 & -- & -- & -- & -- & -- & -- & -- & 245 & 110 & $<4$ & 58 \\
\hline $5 / 4 / 2009$ & 1057 & -- & -- & -- & -- & -- & -- & -- & -- & -- & -- & -- \\
\hline
\end{tabular}


Table 5. Summary of physical property data from water samples collected as part of the Equus Beds Experimental Passive Recharge Project at RB1, 2009-2010.-Continued $\left[\mathrm{mg} / \mathrm{L}\right.$, milligrams per liter; $\mu \mathrm{S} / \mathrm{cm}$, microsiemens per centimeter at 25 degrees Celsius; ${ }^{\circ} \mathrm{C}$, degrees Celsius; +/-, plus or minus; NTU, nephelometric turbidity units; NTRU, nephelometric turbidity ratiometric units; $\mathrm{mV}$, millivolts; $\mathrm{CaCO}_{3}$, calcium carbonate; --, not determined or not applicable; <, less than; $\mathrm{M}^{*}$, presence of material verified, but not quantified; $\mathrm{E}^{* *}$, estimated]

\begin{tabular}{|c|c|c|c|c|c|c|c|c|c|c|c|c|}
\hline $\begin{array}{c}\text { Date of } \\
\text { sample } \\
\text { collection } \\
\text { (month/day/ } \\
\text { year) }\end{array}$ & $\begin{array}{l}\text { Sample } \\
\text { start } \\
\text { time }\end{array}$ & $\begin{array}{l}\text { Dissolved } \\
\text { oxygen } \\
\text { (mg/L) }\end{array}$ & $\begin{array}{l}\text { pH, field } \\
\text { (standard } \\
\text { units) }\end{array}$ & $\begin{array}{c}\text { Specific } \\
\text { conductance } \\
\text { ( } \mathrm{S} / \mathrm{cm})\end{array}$ & $\begin{array}{c}\text { Water } \\
\text { temperature } \\
\left({ }^{\circ} \mathrm{C}\right)\end{array}$ & $\begin{array}{c}\text { Turbdity, } \\
\text { detection } \\
\text { angle } 90+/-30 \\
\text { degrees } \\
\text { (NTU) }\end{array}$ & $\begin{array}{l}\text { Turbidity, detectors } \\
\text { at multiple angles } \\
\text { including } \\
90+/-30 \text { degrees, } \\
\text { radiometric correction } \\
\text { (NTRU) }\end{array}$ & $\begin{array}{c}\text { Oxidation- } \\
\text { reduction (redox) } \\
\text { potential } \\
\text { (mV relative to the } \\
\text { standard hydrogen } \\
\text { electrode) } \\
\end{array}$ & $\begin{array}{l}\text { Dissolved } \\
\text { solids } \\
\text { (mg/L) }\end{array}$ & $\begin{array}{l}\text { Hardness } \\
\text { as } \mathrm{CaCO}_{3} \\
(\mathrm{mg} / \mathrm{L})\end{array}$ & $\begin{array}{l}\text { Suspended } \\
\text { solids } \\
\text { (mg/L) }\end{array}$ & $\begin{array}{c}\text { Alkalinity } \\
\text { as } \mathrm{CaCO}_{3} \\
(\mathrm{mg} / \mathrm{L})\end{array}$ \\
\hline \multicolumn{13}{|c|}{ RB1-TR-Continued } \\
\hline $5 / 4 / 2009$ & 1100 & 6.6 & 7.0 & 407 & 16.5 & -- & 0.9 & 390 & -- & -- & -- & -- \\
\hline $5 / 19 / 2009$ & 1020 & 2.9 & 6.9 & 493 & 16.4 & -- & 1.4 & 440 & -- & -- & -- & -- \\
\hline $5 / 19 / 2009$ & 1021 & -- & -- & -- & -- & -- & -- & -- & 306 & 160 & $<4$ & 132 \\
\hline $5 / 19 / 2009$ & 1025 & 2.9 & 6.9 & 493 & 16.4 & -- & 1.4 & 440 & -- & -- & -- & -- \\
\hline \multicolumn{13}{|c|}{ Diverted SW, PAC building } \\
\hline $4 / 3 / 2009$ & 1010 & 10.4 & 7.4 & 522 & 7.0 & -- & 215.0 & 430 & -- & -- & -- & -- \\
\hline 4/3/2009 & 1011 & -- & -- & -- & -- & -- & -- & -- & 314 & 169 & 176 & 96 \\
\hline 4/3/2009 & 1015 & 10.4 & 7.4 & 522 & 7.0 & -- & 215.0 & 430 & -- & -- & -- & -- \\
\hline 4/14/2009 & 1010 & 10.1 & 7.4 & 496 & 8.7 & -- & 274.0 & 550 & -- & -- & -- & -- \\
\hline 4/14/2009 & 1011 & -- & -- & -- & -- & -- & -- & -- & 322 & 153 & 317 & 106 \\
\hline 4/17/2009 & 0950 & 8.7 & 7.5 & 721 & 14.5 & -- & 105.0 & 390 & -- & & -- & -- \\
\hline $4 / 17 / 2009$ & 0951 & -- & -- & -- & -- & -- & -- & -- & 450 & 245 & 75 & 154 \\
\hline
\end{tabular}

"National Water Information System: Web Interface Help System, accessed March 17, 2011, at http://nwis.waterdata.usgs.gov/nwis/help/help?codes_help\#remark_cd.

${ }^{*}$ Values may be reported as estimated (E) if values are out of instrument calibration range, data quantification was not performed according to method specific criteria, or deviation for the standard operating procedure was required. Values are considered detections. (Childress and others, 1999). 
Table 6. Summary of bacterial and viral indicator data from water samples collected as part of the Equus Beds Experimental Passive Recharge Project at RB1, 2009-2010.

[mCP, membrane filtration Clostridum perfringens agar; MF, membrane filter; $\mathrm{CFU} / 100 \mathrm{~mL}$, colony forming units per 100 milliliters; E. coli, Escherichia coli; C13, E. coli culture resistant to naladixic acid and used to detect somatic coliphages; PFU/100 milliliters, plaque forming units per 100 milliliters; Famp, E. coli culture resistant to ampicillin and streptomycin and used to detect male-specific coliphages; MPN/100 mL, most probable number per 100 milliliters; m-TEC, membrane-thermotolerant Escherichia coli; M-FC, membrane method fecal coliform; LES, Lawrence Experiment Station;

,-- not determined or not applicable; $<$, less than; $E^{* *}$, estimated; >, greater than]

\begin{tabular}{|c|c|c|c|c|c|c|c|c|c|c|c|}
\hline $\begin{array}{c}\text { Date of } \\
\text { sample } \\
\text { collection } \\
\text { (month/day/ } \\
\text { year) }\end{array}$ & $\begin{array}{c}\text { Sample } \\
\text { start } \\
\text { time }\end{array}$ & $\begin{array}{c}\text { Clostridium } \\
\text { perfringens, } \\
\text { mCP MF } \\
\text { method } \\
\text { (CFU/100 mL) }\end{array}$ & $\begin{array}{l}\text { Coliphage, } \\
\text { E. coli, } \\
\text { C13 host, } \\
\text { MF method } \\
\text { (PFU/100 mL) }\end{array}$ & $\begin{array}{c}\text { Coliphage, } \\
\text { E. coli, } \\
\text { Famp host, } \\
\text { MF method } \\
\text { (PFU/100 mL) }\end{array}$ & $\begin{array}{c}\text { Escherichia } \\
\text { coli, } \\
\text { defined } \\
\text { substrate } \\
\text { technology } \\
\text { (MPN/100 mL) }\end{array}$ & $\begin{array}{c}\text { Escherichia } \\
\text { coli, } \\
\text { modified } \\
\text { m-TEC MF } \\
\text { method } \\
\text { (CFU/100 mL) }\end{array}$ & $\begin{array}{c}\text { Fecal } \\
\text { coliform, } \\
\text { M-FC MF } \\
\text { (0.7 micron) } \\
\text { method } \\
\text { (CFU/100 mL) }\end{array}$ & $\begin{array}{c}\text { Total } \\
\text { coliform, } \\
\text { defined } \\
\text { substrate } \\
\text { technology } \\
\text { (MPN/100 mL) }\end{array}$ & $\begin{array}{c}\text { Total } \\
\text { coliform, } \\
\text { LES Endo } \\
\text { method } \\
\text { (CFU/100 mL) }\end{array}$ & $\begin{array}{c}\text { Total } \\
\text { coliform } \\
\text { (CFU/100 mL) }\end{array}$ & $\begin{array}{c}\text { Total } \\
\text { coliform, } \\
\text { water, } \\
\text { m-ColiBlue } \\
\text { method } \\
\text { (CFU/100 mL) }\end{array}$ \\
\hline
\end{tabular}

\begin{tabular}{|c|c|c|c|c|c|c|c|}
\hline & & & & \multicolumn{4}{|c|}{ IW-09 shallow } \\
\hline $3 / 19 / 2002$ & 1101 & -- & -- & -- & -- & -- & 1 \\
\hline $6 / 20 / 2002$ & 0936 & -- & -- & -- & -- & -- & $<1$ \\
\hline $2 / 14 / 2003$ & 1036 & -- & -- & -- & -- & -- & $<1$ \\
\hline $6 / 25 / 2003$ & 0856 & -- & -- & -- & -- & -- & $<1$ \\
\hline $2 / 10 / 2004$ & 1030 & $<1$ & $<1$ & $<1$ & -- & -- & -- \\
\hline $6 / 25 / 2004$ & 0926 & -- & -- & -- & -- & -- & $<1$ \\
\hline $7 / 11 / 2005$ & 1201 & -- & -- & -- & -- & -- & $<1$ \\
\hline $6 / 14 / 2006$ & 1046 & -- & -- & -- & -- & -- & $<1$ \\
\hline $6 / 20 / 2007$ & 1020 & -- & $<1$ & $<1$ & -- & -- & -- \\
\hline $6 / 20 / 2007$ & 1021 & -- & -- & -- & -- & -- & $<1$ \\
\hline $6 / 12 / 2008$ & 0941 & -- & -- & -- & -- & -- & $<1$ \\
\hline $2 / 10 / 2009$ & 0955 & $<1$ & $<1$ & $<1$ & -- & -- & -- \\
\hline $2 / 10 / 2009$ & 0956 & -- & -- & -- & $<1$ & -- & $<1$ \\
\hline 4/2/2009 & 1055 & $<1$ & $<1$ & $<1$ & -- & -- & -- \\
\hline $4 / 2 / 2009$ & 1056 & -- & -- & -- & $<1$ & -- & $<1$ \\
\hline $4 / 22 / 2009$ & 1020 & $<1$ & $<1$ & $<1$ & -- & -- & -- \\
\hline $4 / 22 / 2009$ & 1021 & -- & -- & -- & $<1$ & -- & $<1$ \\
\hline $6 / 10 / 2009$ & 0956 & -- & -- & -- & $<1$ & -- & $<1$ \\
\hline $7 / 14 / 2009$ & 1020 & $<1$ & $<1$ & $<1$ & -- & -- & -- \\
\hline $7 / 14 / 2009$ & 1021 & -- & -- & -- & $<1$ & -- & $<1$ \\
\hline $8 / 19 / 2009$ & 1000 & $<1$ & $<1$ & $<1$ & -- & -- & -- \\
\hline $8 / 19 / 2009$ & 1001 & -- & -- & -- & $<1$ & -- & $<1$ \\
\hline $11 / 17 / 2009$ & 1005 & $<1$ & $<1$ & $<1$ & -- & $<1$ & E2 \\
\hline $11 / 17 / 2009$ & 1006 & -- & -- & -- & $<1$ & -- & $<1$ \\
\hline 3/9/2010 & 1010 & $<1$ & $<1$ & $<1$ & -- & $<1$ & $<1$ \\
\hline $3 / 9 / 2010$ & 1011 & -- & -- & -- & $<1$ & -- & $<1$ \\
\hline
\end{tabular}

$\begin{array}{cc}-- & 99 \\ -- & 2 \\ -- & <1 \\ -- & 2 \\ -- & -- \\ -- & 6 \\ -- & <1 \\ -- & <1 \\ -- & -- \\ -- & <1 \\ -- & <1 \\ -- & -- \\ 1 & <1 \\ -- & -- \\ <1 & <1 \\ -- & -- \\ <1 & <1 \\ <1 & <1 \\ -- & -- \\ <1 & <1 \\ -- & -- \\ <1 & <1 \\ -- & -- \\ <1 & <1 \\ -- & -- \\ <1 & <1 \\ -1 & \end{array}$


Table 6. Summary of bacterial and viral indicator data from water samples collected as part of the Equus Beds Experimental Passive Recharge Project at RB1, 2009-2010.Continued

[mCP, membrane filtration Clostridum perfringens agar; MF, membrane filter; CFU/100 mL, colony forming units per 100 milliliters; E. coli, Escherichia coli; C13, E. coli culture resistant to naladixic acid and used to detect somatic coliphages; PFU/100 milliliters, plaque forming units per 100 milliliters; Famp, E. coli culture resistant to ampicillin and streptomycin and used to detect male-specific coliphages; MPN/100 mL, most probable number per 100 milliliters; m-TEC, membrane-thermotolerant Escherichia coli; M-FC, membrane method fecal coliform; LES, Lawrence Experiment Station;

,-- not determined or not applicable; $<$, less than; $E^{* *}$, estimated; $>$, greater than]

\begin{tabular}{|c|c|c|c|c|c|c|c|c|c|c|c|}
\hline $\begin{array}{c}\text { Date of } \\
\text { sample } \\
\text { collection } \\
\text { (month/day/ } \\
\text { year) }\end{array}$ & $\begin{array}{c}\text { Sample } \\
\text { start } \\
\text { time }\end{array}$ & $\begin{array}{c}\text { Clostridium } \\
\text { perfringens, } \\
\text { mCP MF } \\
\text { method } \\
\text { (CFU/100 mL) }\end{array}$ & $\begin{array}{c}\text { Coliphage, } \\
\text { E. coli, } \\
\text { C13 host, } \\
\text { MF method } \\
\text { (PFU/100 mL) }\end{array}$ & $\begin{array}{c}\text { Coliphage, } \\
\text { E. coli, } \\
\text { Famp host, } \\
\text { MF method } \\
\text { (PFU/100 mL) }\end{array}$ & $\begin{array}{c}\text { Escherichia } \\
\text { coli, } \\
\text { defined } \\
\text { substrate } \\
\text { technology } \\
\text { (MPN/100 mL) }\end{array}$ & $\begin{array}{c}\text { Escherichia } \\
\text { coli, } \\
\text { modified } \\
\text { m-TEC MF } \\
\text { method } \\
\text { (CFU/100 mL) }\end{array}$ & $\begin{array}{c}\text { Fecal } \\
\text { coliform, } \\
\text { M-FC MF } \\
\text { (0.7 micron) } \\
\text { method } \\
\text { (CFU/100 mL) }\end{array}$ & $\begin{array}{c}\text { Total } \\
\text { coliform, } \\
\text { defined } \\
\text { substrate } \\
\text { technology } \\
\text { (MPN/100 mL) }\end{array}$ & $\begin{array}{c}\text { Total } \\
\text { coliform, } \\
\text { LES Endo } \\
\text { method } \\
\text { (CFU/100 mL) }\end{array}$ & $\begin{array}{c}\text { Total } \\
\text { coliform } \\
\text { (CFU/100 mL) }\end{array}$ & $\begin{array}{c}\text { Total } \\
\text { coliform, } \\
\text { water, } \\
\text { m-ColiBlue } \\
\text { method } \\
\text { (CFU/100 mL) }\end{array}$ \\
\hline
\end{tabular}

\begin{tabular}{|c|c|c|c|c|c|c|c|c|c|c|c|}
\hline \multicolumn{12}{|c|}{ IW-09 deep } \\
\hline $3 / 19 / 2002$ & 1306 & -- & -- & -- & -- & -- & $<1$ & -- & 20 & -- & -- \\
\hline $6 / 24 / 2002$ & 1046 & -- & -- & -- & -- & -- & $<1$ & -- & 5 & -- & -- \\
\hline $2 / 14 / 2003$ & 1336 & -- & -- & -- & -- & -- & $<1$ & -- & $<1$ & -- & -- \\
\hline $6 / 25 / 2003$ & 1136 & -- & -- & -- & -- & -- & $<1$ & -- & $<1$ & -- & -- \\
\hline $2 / 10 / 2004$ & 1225 & $<1$ & $<1$ & $<1$ & -- & -- & -- & -- & -- & -- & -- \\
\hline $2 / 10 / 2004$ & 1226 & -- & -- & -- & -- & -- & $<1$ & -- & $<1$ & -- & -- \\
\hline $6 / 25 / 2004$ & 1131 & -- & -- & -- & -- & -- & $<1$ & -- & 1 & -- & -- \\
\hline $7 / 11 / 2005$ & 1031 & -- & -- & -- & -- & -- & $<1$ & -- & $<1$ & -- & -- \\
\hline $6 / 14 / 2006$ & 1236 & -- & -- & -- & -- & -- & $<1$ & -- & $<1$ & -- & -- \\
\hline $6 / 20 / 2007$ & 1221 & -- & -- & -- & -- & -- & $<1$ & -- & $<1$ & -- & -- \\
\hline $6 / 12 / 2008$ & 1111 & -- & -- & -- & -- & -- & $<1$ & -- & $<1$ & -- & -- \\
\hline $2 / 10 / 2009$ & 1125 & $<1$ & $<1$ & $<1$ & -- & -- & -- & -- & -- & -- & -- \\
\hline $2 / 10 / 2009$ & 1126 & -- & -- & -- & $<1$ & -- & $<1$ & $<1$ & $<1$ & -- & -- \\
\hline $4 / 2 / 2009$ & 1215 & $<1$ & $<1$ & $<1$ & -- & -- & -- & -- & -- & -- & -- \\
\hline $4 / 2 / 2009$ & 1216 & -- & -- & -- & $<1$ & -- & $<1$ & $<1$ & $<1$ & -- & -- \\
\hline $4 / 22 / 2009$ & 1200 & $<1$ & $<1$ & $<1$ & -- & -- & -- & -- & -- & -- & -- \\
\hline $4 / 22 / 2009$ & 1201 & -- & -- & -- & $<1$ & -- & $<1$ & $<1$ & $<1$ & -- & -- \\
\hline $6 / 10 / 2009$ & 1121 & -- & -- & -- & $<1$ & -- & $<1$ & $<1$ & $<1$ & -- & -- \\
\hline $7 / 14 / 2009$ & 1150 & $<1$ & $<1$ & $<1$ & -- & -- & -- & -- & -- & -- & -- \\
\hline $7 / 14 / 2009$ & 1151 & -- & -- & -- & $<1$ & -- & $<1$ & $<1$ & $<1$ & -- & -- \\
\hline $8 / 19 / 2009$ & 1150 & $<1$ & $<1$ & $<1$ & -- & -- & -- & -- & -- & -- & -- \\
\hline 8/19/2009 & 1151 & -- & -- & -- & $<1$ & -- & $<1$ & $<1$ & $<1$ & -- & -- \\
\hline $11 / 17 / 2009$ & 1146 & -- & -- & -- & $<1$ & -- & 2 & $<1$ & $<1$ & -- & -- \\
\hline 3/9/2010 & 1155 & $<1$ & $<1$ & $<1$ & -- & $<1$ & $<1$ & -- & -- & $<1$ & -- \\
\hline $3 / 9 / 2010$ & 1156 & -- & -- & -- & $<1$ & -- & $<1$ & $<1$ & $<1$ & -- & -- \\
\hline
\end{tabular}


Table 6. Summary of bacterial and viral indicator data from water samples collected as part of the Equus Beds Experimental Passive Recharge Project at RB1, 2009-2010.Continued

[mCP, membrane filtration Clostridum perfringens agar; MF, membrane filter; CFU/100 mL, colony forming units per 100 milliliters; E. coli, Escherichia coli; C13, E. coli culture resistant to naladixic acid and used to detect somatic coliphages; PFU/100 milliliters, plaque forming units per 100 milliliters; Famp, E. coli culture resistant to ampicillin and streptomycin and used to detect male-specific coliphages; MPN/100 mL, most probable number per 100 milliliters; m-TEC, membrane-thermotolerant Escherichia coli; M-FC, membrane method fecal coliform; LES, Lawrence Experiment Station;

,-- not determined or not applicable; $<$, less than; $\mathrm{E}^{* *}$, estimated; >, greater than]

\begin{tabular}{|c|c|c|c|c|c|c|c|c|c|c|c|}
\hline $\begin{array}{c}\text { Date of } \\
\text { sample } \\
\text { collection } \\
\text { (month/day/ } \\
\text { year) }\end{array}$ & $\begin{array}{c}\text { Sample } \\
\text { start } \\
\text { time }\end{array}$ & $\begin{array}{c}\text { Clostridium } \\
\text { perfringens, } \\
\text { mCP MF } \\
\text { method } \\
\text { (CFU/100 mL) }\end{array}$ & $\begin{array}{c}\text { Coliphage, } \\
\text { E. coli, } \\
\text { C13 host, } \\
\text { MF method } \\
\text { (PFU/100 mL) }\end{array}$ & $\begin{array}{l}\text { Coliphage, } \\
\text { E. coli, } \\
\text { Famp host, } \\
\text { MF method } \\
\text { (PFU/100 mL) }\end{array}$ & $\begin{array}{c}\text { Escherichia } \\
\text { coli, } \\
\text { defined } \\
\text { substrate } \\
\text { technology } \\
\text { (MPN/100 mL) }\end{array}$ & $\begin{array}{c}\text { Escherichia } \\
\text { coli, } \\
\text { modified } \\
\text { m-TEC MF } \\
\text { method } \\
\text { (CFU/100 mL) }\end{array}$ & $\begin{array}{c}\text { Fecal } \\
\text { coliform, } \\
\text { M-FC MF } \\
\text { (0.7 micron) } \\
\text { method } \\
\text { (CFU/100 mL) }\end{array}$ & $\begin{array}{c}\text { Total } \\
\text { coliform, } \\
\text { defined } \\
\text { substrate } \\
\text { technology } \\
\text { (MPN/100 mL) }\end{array}$ & $\begin{array}{c}\text { Total } \\
\text { coliform, } \\
\text { LES Endo } \\
\text { method } \\
\text { (CFU/100 mL) }\end{array}$ & $\begin{array}{c}\text { Total } \\
\text { coliform } \\
\text { (CFU/100 mL) }\end{array}$ & $\begin{array}{c}\text { Total } \\
\text { coliform, } \\
\text { water, } \\
\text { m-ColiBlue } \\
\text { method } \\
\text { (CFU/100 mL) }\end{array}$ \\
\hline \multicolumn{12}{|c|}{ RB1 source water } \\
\hline $8 / 3 / 2007$ & 1106 & -- & -- & -- & -- & -- & 120 & -- & 180 & -- & -- \\
\hline $8 / 3 / 2007$ & 1116 & -- & -- & -- & -- & -- & 120 & -- & 180 & -- & -- \\
\hline $4 / 3 / 2009$ & 1215 & $<1$ & 1 & $<1$ & -- & -- & -- & -- & -- & -- & -- \\
\hline $4 / 3 / 2009$ & 1216 & -- & -- & -- & 34 & -- & 22 & $>200$ & 37 & -- & -- \\
\hline $4 / 14 / 2009$ & 1140 & $<1$ & 980 & $<1$ & -- & -- & -- & -- & -- & -- & -- \\
\hline $4 / 14 / 2009$ & 1141 & -- & -- & -- & 390 & -- & 200 & $>2,400$ & 110 & -- & -- \\
\hline $4 / 17 / 2009$ & 1110 & E1 & 52 & $<1$ & -- & -- & -- & -- & -- & -- & -- \\
\hline $4 / 17 / 2009$ & 1111 & -- & -- & -- & 14 & -- & 5 & 520 & 23 & -- & -- \\
\hline \multicolumn{12}{|c|}{ RB1-MN shallow } \\
\hline $8 / 30 / 2006$ & 1011 & -- & -- & -- & -- & -- & 3 & -- & 1 & -- & -- \\
\hline $11 / 29 / 2006$ & 1101 & -- & -- & -- & -- & -- & $<1$ & -- & $<1$ & -- & -- \\
\hline $2 / 23 / 2007$ & 1011 & -- & -- & -- & -- & -- & $<1$ & -- & $<1$ & -- & -- \\
\hline $6 / 4 / 2007$ & 1016 & -- & -- & -- & -- & -- & $<1$ & -- & $<1$ & -- & -- \\
\hline $8 / 29 / 2007$ & 1021 & -- & -- & -- & -- & -- & $<1$ & -- & $<1$ & -- & -- \\
\hline $8 / 29 / 2007$ & 1031 & -- & -- & -- & -- & -- & $<1$ & -- & $<1$ & -- & -- \\
\hline $3 / 5 / 2008$ & 1026 & -- & -- & -- & -- & -- & $<1$ & -- & $<1$ & -- & -- \\
\hline $3 / 5 / 2008$ & 1031 & -- & -- & -- & -- & -- & $<1$ & -- & $<1$ & -- & -- \\
\hline $8 / 19 / 2008$ & 1011 & -- & -- & -- & -- & -- & $<1$ & -- & $<1$ & -- & -- \\
\hline $2 / 9 / 2009$ & 1020 & $<1$ & $<1$ & $<1$ & -- & -- & -- & -- & -- & -- & -- \\
\hline 2/9/2009 & 1021 & -- & -- & -- & $<1$ & -- & $<1$ & 1 & $<1$ & -- & -- \\
\hline $4 / 1 / 2009$ & 1110 & $<1$ & $<1$ & $<1$ & -- & -- & -- & -- & -- & -- & -- \\
\hline $4 / 1 / 2009$ & 1111 & -- & -- & -- & $<1$ & -- & $<1$ & $<1$ & $<1$ & -- & -- \\
\hline $4 / 21 / 2009$ & 0955 & $<1$ & $<1$ & $<1$ & -- & -- & -- & -- & -- & -- & -- \\
\hline $4 / 21 / 2009$ & 0956 & -- & -- & -- & $<1$ & -- & $<1$ & $<1$ & $<1$ & -- & -- \\
\hline $6 / 25 / 2009$ & 1000 & $<1$ & $<1$ & $<1$ & -- & -- & -- & -- & -- & -- & -- \\
\hline $6 / 25 / 2009$ & 1001 & -- & -- & -- & $<1$ & -- & $<1$ & $<1$ & $<1$ & -- & -- \\
\hline $7 / 14 / 2009$ & 1025 & $<1$ & $<1$ & $<1$ & -- & -- & -- & -- & -- & -- & -- \\
\hline $7 / 14 / 2009$ & 1026 & -- & -- & -- & $<1$ & -- & $<1$ & $<1$ & $<1$ & -- & -- \\
\hline $8 / 19 / 2009$ & 0956 & -- & -- & -- & $<1$ & -- & $<1$ & $<1$ & $<1$ & -- & -- \\
\hline $11 / 18 / 2009$ & 1000 & $<1$ & $<1$ & $<1$ & -- & $<1$ & $<1$ & -- & -- & -- & -- \\
\hline $11 / 18 / 2009$ & 1001 & -- & -- & -- & $<1$ & -- & $<1$ & $<1$ & $<1$ & -- & -- \\
\hline $3 / 8 / 2010$ & 1005 & $<1$ & $<1$ & $<1$ & -- & $<1$ & $<1$ & -- & -- & $<1$ & -- \\
\hline $3 / 8 / 2010$ & 1006 & -- & -- & -- & $<1$ & -- & $<1$ & $<1$ & $<1$ & -- & -- \\
\hline
\end{tabular}


Table 6. Summary of bacterial and viral indicator data from water samples collected as part of the Equus Beds Experimental Passive Recharge Project at RB1, 2009-2010.Continued

[mCP, membrane filtration Clostridum perfringens agar; MF, membrane filter; $\mathrm{CFU} / 100 \mathrm{~mL}$, colony forming units per 100 milliliters; E. coli, Escherichia coli; C13, E. coli culture resistant to naladixic acid and used to detect somatic coliphages; PFU/100 milliliters, plaque forming units per 100 milliliters; Famp, E. coli culture resistant to ampicillin and streptomycin and used to detect male-specific coliphages; MPN/100 mL, most probable number per 100 milliliters; m-TEC, membrane-thermotolerant Escherichia coli; M-FC, membrane method fecal coliform; LES, Lawrence Experiment Station;

--, not determined or not applicable; <, less than; $\mathrm{E}^{* *}$, estimated; $>$, greater than]

\begin{tabular}{|c|c|c|c|c|c|c|c|c|c|c|c|}
\hline $\begin{array}{c}\text { Date of } \\
\text { sample } \\
\text { collection } \\
\text { (month/day/ } \\
\text { year) }\end{array}$ & $\begin{array}{c}\text { Sample } \\
\text { start } \\
\text { time }\end{array}$ & $\begin{array}{c}\text { Clostridium } \\
\text { perfringens, } \\
\text { mCP MF } \\
\text { method } \\
\text { (CFU/100 mL) }\end{array}$ & $\begin{array}{c}\text { Coliphage, } \\
\text { E. coli, } \\
\text { C13 host, } \\
\text { MF method } \\
\text { (PFU/100 mL) }\end{array}$ & $\begin{array}{l}\text { Coliphage, } \\
\text { E. coli, } \\
\text { Famp host, } \\
\text { MF method } \\
\text { (PFU/100 mL) }\end{array}$ & $\begin{array}{c}\text { Escherichia } \\
\text { coli, } \\
\text { defined } \\
\text { substrate } \\
\text { technology } \\
\text { (MPN/100 mL) }\end{array}$ & $\begin{array}{c}\text { Escherichia } \\
\text { coli, } \\
\text { modified } \\
\text { m-TEC MF } \\
\text { method } \\
\text { (CFU/100 mL) }\end{array}$ & $\begin{array}{c}\text { Fecal } \\
\text { coliform, } \\
\text { M-FC MF } \\
\text { (0.7 micron) } \\
\text { method } \\
\text { (CFU } / 100 \mathrm{~mL} \text { ) }\end{array}$ & $\begin{array}{c}\text { Total } \\
\text { coliform, } \\
\text { defined } \\
\text { substrate } \\
\text { technology } \\
\text { (MPN/100 mL) }\end{array}$ & $\begin{array}{c}\text { Total } \\
\text { coliform, } \\
\text { LES Endo } \\
\text { method } \\
\text { (CFU/100 mL) }\end{array}$ & $\begin{array}{c}\text { Total } \\
\text { coliform } \\
\text { (CFU/100 mL) }\end{array}$ & $\begin{array}{c}\text { Total } \\
\text { coliform, } \\
\text { water, } \\
\text { m-ColiBlue } \\
\text { method } \\
\text { (CFU/100 mL) }\end{array}$ \\
\hline
\end{tabular}

\begin{tabular}{|c|c|c|c|c|c|c|c|c|c|c|c|}
\hline \multicolumn{12}{|c|}{ RB1-MN deep } \\
\hline $8 / 30 / 2006$ & 1156 & -- & -- & -- & -- & -- & $<1$ & -- & $<1$ & -- & -- \\
\hline $11 / 29 / 2006$ & 0956 & -- & -- & -- & -- & -- & $<1$ & -- & $<1$ & -- & -- \\
\hline $2 / 23 / 2007$ & 1206 & -- & -- & -- & -- & -- & $<1$ & -- & $<1$ & -- & -- \\
\hline $6 / 4 / 2007$ & 1141 & -- & -- & -- & -- & -- & $<1$ & -- & $<1$ & -- & -- \\
\hline $6 / 4 / 2007$ & 1146 & -- & -- & -- & -- & -- & $<1$ & -- & $<1$ & -- & -- \\
\hline $8 / 29 / 2007$ & 1231 & -- & -- & -- & -- & -- & $<1$ & -- & $<1$ & -- & -- \\
\hline $3 / 5 / 2008$ & 1156 & -- & -- & -- & -- & -- & $<1$ & -- & $<1$ & -- & -- \\
\hline $8 / 19 / 2008$ & 1151 & -- & -- & -- & -- & -- & $<1$ & -- & $<1$ & -- & -- \\
\hline $2 / 9 / 2009$ & 1150 & $<1$ & $<1$ & $<1$ & -- & -- & -- & -- & -- & -- & -- \\
\hline 2/9/2009 & 1151 & -- & -- & -- & $<1$ & -- & $<1$ & $<1$ & $<1$ & -- & -- \\
\hline $4 / 1 / 2009$ & 1240 & $<1$ & $<1$ & $<1$ & -- & -- & -- & -- & -- & -- & -- \\
\hline $4 / 1 / 2009$ & 1241 & -- & -- & -- & $<1$ & -- & $<1$ & $<1$ & $<1$ & -- & -- \\
\hline $4 / 21 / 2009$ & 1115 & $<1$ & $<1$ & $<1$ & -- & -- & -- & -- & -- & -- & -- \\
\hline $4 / 21 / 2009$ & 1116 & -- & -- & -- & $<1$ & -- & $<1$ & $<1$ & $<1$ & -- & -- \\
\hline $6 / 25 / 2009$ & 1200 & $<1$ & $<1$ & $<1$ & -- & -- & -- & -- & -- & -- & -- \\
\hline $6 / 25 / 2009$ & 1201 & -- & -- & -- & $<1$ & -- & $<1$ & $<1$ & $<1$ & -- & -- \\
\hline $6 / 25 / 2009$ & 1210 & $<1$ & $<1$ & $<1$ & -- & -- & -- & -- & -- & -- & -- \\
\hline $6 / 25 / 2009$ & 1211 & -- & -- & -- & $<1$ & -- & $<1$ & $<1$ & $<1$ & -- & -- \\
\hline $7 / 14 / 2009$ & 1200 & $<1$ & $<1$ & $<1$ & -- & -- & -- & -- & -- & -- & -- \\
\hline $7 / 14 / 2009$ & 1201 & -- & -- & -- & $<1$ & -- & $<1$ & $<1$ & $<1$ & -- & -- \\
\hline $8 / 19 / 2009$ & 1125 & $<1$ & $<1$ & $<1$ & -- & -- & -- & -- & -- & -- & -- \\
\hline $8 / 19 / 2009$ & 1126 & -- & -- & -- & $<1$ & -- & $<1$ & $<1$ & $<1$ & -- & -- \\
\hline $11 / 18 / 2009$ & 1130 & $<1$ & $<1$ & $<1$ & -- & $<1$ & $<1$ & -- & -- & -- & -- \\
\hline $11 / 18 / 2009$ & 1131 & -- & -- & -- & $<1$ & -- & $<1$ & $<1$ & $<1$ & -- & -- \\
\hline 3/8/2010 & 1145 & $<1$ & $<1$ & $<1$ & -- & $<1$ & $<1$ & -- & -- & $<1$ & -- \\
\hline $3 / 8 / 2010$ & 1146 & -- & -- & -- & $<1$ & -- & $<1$ & $<1$ & $<1$ & -- & -- \\
\hline
\end{tabular}


Table 6. Summary of bacterial and viral indicator data from water samples collected as part of the Equus Beds Experimental Passive Recharge Project at RB1, 2009-2010.Continued

[mCP, membrane filtration Clostridum perfringens agar; MF, membrane filter; CFU/100 mL, colony forming units per 100 milliliters; E. coli, Escherichia coli; C13, E. coli culture resistant to naladixic acid and used to detect somatic coliphages; PFU/100 milliliters, plaque forming units per 100 milliliters; Famp, E. coli culture resistant to ampicillin and streptomycin and used to detect male-specific coliphages; MPN/100 mL, most probable number per 100 milliliters; m-TEC, membrane-thermotolerant Escherichia coli; M-FC, membrane method fecal coliform; LES, Lawrence Experiment Station;

,-- not determined or not applicable; $<$, less than; $\mathrm{E}^{* *}$, estimated; >, greater than]

\begin{tabular}{|c|c|c|c|c|c|c|c|c|c|c|c|}
\hline $\begin{array}{c}\text { Date of } \\
\text { sample } \\
\text { collection } \\
\text { (month/day/ } \\
\text { year) }\end{array}$ & $\begin{array}{c}\text { Sample } \\
\text { start } \\
\text { time }\end{array}$ & $\begin{array}{c}\text { Clostridium } \\
\text { perfringens, } \\
\text { mCP MF } \\
\text { method } \\
\text { (CFU/100 mL) }\end{array}$ & $\begin{array}{c}\text { Coliphage, } \\
\text { E. coli, } \\
\text { C13 host, } \\
\text { MF method } \\
\text { (PFU/100 mL) }\end{array}$ & $\begin{array}{l}\text { Coliphage, } \\
\text { E. coli, } \\
\text { Famp host, } \\
\text { MF method } \\
\text { (PFU/100 mL) }\end{array}$ & $\begin{array}{c}\text { Escherichia } \\
\text { coli, } \\
\text { defined } \\
\text { substrate } \\
\text { technology } \\
\text { (MPN/100 mL) }\end{array}$ & $\begin{array}{c}\text { Escherichia } \\
\text { coli, } \\
\text { modified } \\
\text { m-TEC MF } \\
\text { method } \\
\text { (CFU/100 mL) }\end{array}$ & $\begin{array}{c}\text { Fecal } \\
\text { coliform, } \\
\text { M-FC MF } \\
\text { (0.7 micron) } \\
\text { method } \\
\text { (CFU/100 mL) }\end{array}$ & $\begin{array}{c}\text { Total } \\
\text { coliform, } \\
\text { defined } \\
\text { substrate } \\
\text { technology } \\
\text { (MPN/100 mL) }\end{array}$ & $\begin{array}{c}\text { Total } \\
\text { coliform, } \\
\text { LES Endo } \\
\text { method } \\
\text { (CFU/100 mL) }\end{array}$ & $\begin{array}{c}\text { Total } \\
\text { coliform } \\
\text { (CFU/100 mL) }\end{array}$ & $\begin{array}{c}\text { Total } \\
\text { coliform, } \\
\text { water, } \\
\text { m-ColiBlue } \\
\text { method } \\
\text { (CFU/100 mL) }\end{array}$ \\
\hline
\end{tabular}

\begin{tabular}{|c|c|c|c|c|c|c|c|c|c|c|c|}
\hline \multicolumn{12}{|c|}{ RB1-MS shallow } \\
\hline $8 / 30 / 2006$ & 1031 & -- & -- & -- & -- & -- & 6 & -- & $<1$ & -- & -- \\
\hline $11 / 29 / 2006$ & 1011 & -- & -- & -- & -- & -- & $<1$ & -- & $<1$ & -- & -- \\
\hline $2 / 23 / 2007$ & 1031 & -- & -- & -- & -- & -- & $<1$ & -- & $<1$ & -- & -- \\
\hline $6 / 4 / 2007$ & 1021 & -- & -- & -- & -- & -- & $<1$ & -- & $<1$ & -- & -- \\
\hline $8 / 29 / 2007$ & 1016 & -- & -- & -- & -- & -- & $<1$ & -- & $<1$ & -- & - \\
\hline $3 / 4 / 2008$ & 1015 & $<1$ & $<1$ & $<1$ & -- & $<1$ & -- & -- & -- & -- & - \\
\hline 3/4/2008 & 1016 & -- & -- & -- & -- & -- & $<1$ & -- & $<1$ & -- & -- \\
\hline $8 / 18 / 2008$ & 1031 & -- & -- & -- & -- & -- & $<1$ & -- & $<1$ & -- & -- \\
\hline $2 / 4 / 2009$ & 1005 & $<1$ & $<1$ & $<1$ & -- & -- & -- & -- & -- & -- & -- \\
\hline $2 / 4 / 2009$ & 1006 & -- & -- & -- & $>200$ & -- & $<1$ & $<1$ & $<1$ & -- & - \\
\hline $3 / 24 / 2009$ & 1135 & $<1$ & $<1$ & $<1$ & -- & -- & -- & -- & -- & -- & -- \\
\hline $3 / 24 / 2009$ & 1136 & -- & -- & -- & $<1$ & -- & $<1$ & $<1$ & $<1$ & -- & -- \\
\hline $4 / 6 / 2009$ & 1010 & $<1$ & $<1$ & $<1$ & -- & -- & -- & -- & -- & -- & -- \\
\hline $4 / 6 / 2009$ & 1011 & -- & -- & -- & $<1$ & -- & $<1$ & $<1$ & $<1$ & -- & -- \\
\hline 4/9/2009 & 1005 & $<1$ & $<1$ & $<1$ & -- & -- & -- & -- & -- & -- & -- \\
\hline $4 / 9 / 2009$ & 1006 & -- & -- & -- & $<1$ & -- & $<1$ & $<1$ & $<1$ & -- & -- \\
\hline $4 / 16 / 2009$ & 1015 & $<1$ & $<1$ & $<1$ & -- & -- & -- & -- & -- & -- & -- \\
\hline $4 / 16 / 2009$ & 1016 & -- & -- & -- & $<1$ & -- & $<1$ & $<1$ & $<1$ & -- & -- \\
\hline $4 / 20 / 2009$ & 1005 & $<1$ & $<1$ & $<1$ & -- & -- & -- & -- & -- & -- & -- \\
\hline $4 / 20 / 2009$ & 1006 & -- & -- & -- & $<1$ & -- & $<1$ & $<1$ & $<1$ & -- & -- \\
\hline $5 / 6 / 2009$ & 1025 & $<1$ & $<1$ & $<1$ & -- & -- & -- & -- & -- & -- & -- \\
\hline $5 / 6 / 2009$ & 1026 & -- & -- & -- & $<1$ & -- & $<1$ & 12 & 11 & -- & -- \\
\hline $5 / 20 / 2009$ & 1005 & $<1$ & $<1$ & $<1$ & -- & $<1$ & $<1$ & -- & -- & E3 & -- \\
\hline $5 / 20 / 2009$ & 1006 & -- & -- & -- & $<1$ & -- & $<1$ & 6 & $<1$ & -- & -- \\
\hline $6 / 25 / 2009$ & 1000 & $<1$ & $<1$ & $<1$ & -- & -- & -- & -- & -- & -- & -- \\
\hline $6 / 25 / 2009$ & 1001 & -- & -- & -- & $<1$ & -- & $<1$ & $<1$ & $<1$ & -- & -- \\
\hline $7 / 8 / 2009$ & 1020 & $<1$ & $<1$ & $<1$ & -- & -- & -- & -- & -- & -- & -- \\
\hline 7/8/2009 & 1021 & -- & -- & -- & $<1$ & -- & $<1$ & $<1$ & $<1$ & -- & -- \\
\hline $7 / 13 / 2009$ & 1015 & $<1$ & $<1$ & $<1$ & -- & $<1$ & $<1$ & -- & -- & E6 & -- \\
\hline $7 / 13 / 2009$ & 1016 & -- & -- & -- & $<1$ & -- & $<1$ & 3 & $<1$ & -- & -- \\
\hline
\end{tabular}


Table 6. Summary of bacterial and viral indicator data from water samples collected as part of the Equus Beds Experimental Passive Recharge Project at RB1, 2009-2010.Continued

[mCP, membrane filtration Clostridum perfringens agar; MF, membrane filter; $\mathrm{CFU} / 100 \mathrm{~mL}$, colony forming units per 100 milliliters; E. coli, Escherichia coli; C13, E. coli culture resistant to naladixic acid and used to detect somatic coliphages; PFU/100 milliliters, plaque forming units per 100 milliliters; Famp, E. coli culture resistant to ampicillin and streptomycin and used to detect male-specific coliphages; MPN/100 mL, most probable number per 100 milliliters; m-TEC, membrane-thermotolerant Escherichia coli; M-FC, membrane method fecal coliform; LES, Lawrence Experiment Station;

--, not determined or not applicable; <, less than; $\mathrm{E}^{* *}$, estimated; $>$, greater than]

\begin{tabular}{|c|c|c|c|c|c|c|c|c|c|c|c|}
\hline $\begin{array}{c}\text { Date of } \\
\text { sample } \\
\text { collection } \\
\text { (month/day/ } \\
\text { year) }\end{array}$ & $\begin{array}{c}\text { Sample } \\
\text { start } \\
\text { time }\end{array}$ & $\begin{array}{c}\text { Clostridium } \\
\text { perfringens, } \\
\text { mCP MF } \\
\text { method } \\
\text { (CFU/100 mL) }\end{array}$ & $\begin{array}{c}\text { Coliphage, } \\
\text { E. coli, } \\
\text { C13 host, } \\
\text { MF method } \\
\text { (PFU/100 mL) }\end{array}$ & $\begin{array}{c}\text { Coliphage, } \\
\text { E. coli, } \\
\text { Famp host, } \\
\text { MF method } \\
\text { (PFU/100 mL) }\end{array}$ & $\begin{array}{c}\text { Escherichia } \\
\text { coli, } \\
\text { defined } \\
\text { substrate } \\
\text { technology } \\
\text { (MPN/100 mL) }\end{array}$ & $\begin{array}{c}\text { Escherichia } \\
\text { coli, } \\
\text { modified } \\
\text { m-TEC MF } \\
\text { method } \\
\text { (CFU/100 mL) }\end{array}$ & $\begin{array}{c}\text { Fecal } \\
\text { coliform, } \\
\text { M-FC MF } \\
\text { (0.7 micron) } \\
\text { method } \\
\text { (CFU } / 100 \mathrm{~mL} \text { ) }\end{array}$ & $\begin{array}{c}\text { Total } \\
\text { coliform, } \\
\text { defined } \\
\text { substrate } \\
\text { technology } \\
\text { (MPN/100 mL) }\end{array}$ & $\begin{array}{c}\text { Total } \\
\text { coliform, } \\
\text { LES Endo } \\
\text { method } \\
\text { (CFU/100 mL) }\end{array}$ & $\begin{array}{c}\text { Total } \\
\text { coliform } \\
\text { (CFU/100 mL) }\end{array}$ & $\begin{array}{c}\text { Total } \\
\text { coliform, } \\
\text { water, } \\
\text { m-ColiBlue } \\
\text { method } \\
\text { (CFU/100 mL) }\end{array}$ \\
\hline
\end{tabular}

\begin{tabular}{|c|c|c|c|c|c|c|c|c|c|c|c|}
\hline \multicolumn{12}{|c|}{ RB1-MS shallow-Continued } \\
\hline 7/20/2009 & 1015 & $<1$ & $<1$ & $<1$ & -- & $<1$ & $<1$ & -- & -- & -- & E17 \\
\hline $7 / 20 / 2009$ & 1016 & -- & -- & -- & $<1$ & -- & $<1$ & 32 & 1 & -- & -- \\
\hline $8 / 18 / 2009$ & 1010 & $<1$ & $<1$ & $<1$ & -- & -- & -- & -- & -- & -- & -- \\
\hline $8 / 18 / 2009$ & 1011 & -- & -- & -- & $<1$ & -- & $<1$ & 1 & 1 & -- & -- \\
\hline $11 / 18 / 2009$ & 1005 & $<1$ & $<1$ & $<1$ & -- & $<1$ & $<1$ & -- & -- & -- & $<1$ \\
\hline $11 / 18 / 2009$ & 1006 & -- & -- & -- & $<1$ & -- & $<1$ & $<1$ & $<1$ & -- & -- \\
\hline $3 / 1 / 2010$ & 1130 & $<1$ & $<1$ & $<1$ & -- & $<1$ & $<1$ & -- & -- & $<1$ & -- \\
\hline $3 / 1 / 2010$ & 1131 & -- & -- & -- & $<1$ & -- & $<1$ & $<1$ & $<1$ & -- & -- \\
\hline \multicolumn{12}{|c|}{ RB1-MS deep } \\
\hline
\end{tabular}

\begin{tabular}{|c|c|c|c|c|c|c|c|c|c|c|c|}
\hline \multicolumn{12}{|c|}{ RBI-IVIS deep } \\
\hline $8 / 30 / 2006$ & 1246 & -- & -- & -- & -- & -- & $<1$ & -- & $<1$ & -- & -- \\
\hline $12 / 4 / 2006$ & 1001 & -- & -- & -- & -- & -- & $<1$ & -- & $<1$ & -- & -- \\
\hline $2 / 23 / 2007$ & 1146 & -- & -- & -- & -- & -- & $<1$ & -- & $<1$ & -- & -- \\
\hline $6 / 4 / 2007$ & 1151 & -- & -- & -- & -- & -- & $<1$ & -- & $<1$ & -- & -- \\
\hline $8 / 29 / 2007$ & 1206 & -- & -- & -- & -- & -- & $<1$ & -- & $<1$ & -- & -- \\
\hline $3 / 4 / 2008$ & 1200 & $<1$ & $<1$ & $<1$ & -- & $<1$ & -- & -- & -- & -- & -- \\
\hline $3 / 4 / 2008$ & 1201 & -- & -- & -- & -- & -- & $<1$ & -- & $<1$ & -- & -- \\
\hline $8 / 18 / 2008$ & 1231 & -- & -- & -- & -- & -- & $<1$ & -- & 1 & -- & -- \\
\hline 2/4/2009 & 1140 & $<1$ & $<1$ & $<1$ & -- & -- & -- & -- & -- & -- & -- \\
\hline $2 / 4 / 2009$ & 1141 & -- & -- & -- & $<1$ & -- & -- & $<1$ & $<1$ & -- & -- \\
\hline $3 / 24 / 2009$ & 1305 & $<1$ & $<1$ & $<1$ & -- & -- & -- & -- & -- & -- & -- \\
\hline $3 / 24 / 2009$ & 1306 & -- & -- & -- & $<1$ & -- & $<1$ & $<1$ & $<1$ & -- & -- \\
\hline $4 / 6 / 2009$ & 1140 & $<1$ & $<1$ & $<1$ & -- & -- & -- & -- & -- & -- & -- \\
\hline $4 / 6 / 2009$ & 1141 & -- & -- & -- & $<1$ & -- & $<1$ & $<1$ & $<1$ & -- & -- \\
\hline 4/9/2009 & 1135 & $<1$ & $<1$ & $<1$ & -- & -- & -- & -- & -- & -- & -- \\
\hline 4/9/2009 & 1136 & -- & -- & -- & $<1$ & -- & $<1$ & $<1$ & $<1$ & -- & -- \\
\hline $4 / 16 / 2009$ & 1140 & $<1$ & $<1$ & $<1$ & -- & -- & -- & -- & -- & -- & -- \\
\hline $4 / 16 / 2009$ & 1141 & -- & -- & -- & $<1$ & -- & $<1$ & $<1$ & $<1$ & -- & -- \\
\hline $4 / 20 / 2009$ & 1135 & $<1$ & $<1$ & $<1$ & -- & -- & -- & -- & -- & -- & -- \\
\hline $4 / 20 / 2009$ & 1136 & -- & -- & -- & $<1$ & -- & $<1$ & $<1$ & $<1$ & -- & -- \\
\hline $5 / 6 / 2009$ & 1150 & $<1$ & $<1$ & $<1$ & -- & -- & -- & -- & -- & -- & -- \\
\hline
\end{tabular}


Table 6. Summary of bacterial and viral indicator data from water samples collected as part of the Equus Beds Experimental Passive Recharge Project at RB1, 2009-2010.Continued

[mCP, membrane filtration Clostridum perfringens agar; MF, membrane filter; CFU/100 mL, colony forming units per 100 milliliters; E. coli, Escherichia coli; C13, E. coli culture resistant to naladixic acid and used to detect somatic coliphages; PFU/100 milliliters, plaque forming units per 100 milliliters; Famp, E. coli culture resistant to ampicillin and streptomycin and used to detect male-specific coliphages; MPN/100 mL, most probable number per 100 milliliters; m-TEC, membrane-thermotolerant Escherichia coli; M-FC, membrane method fecal coliform; LES, Lawrence Experiment Station;

--, not determined or not applicable; <, less than; $\mathrm{E}^{* *}$, estimated; >, greater than]

\begin{tabular}{|c|c|c|c|c|c|c|c|c|c|c|c|}
\hline $\begin{array}{c}\text { Date of } \\
\text { sample } \\
\text { collection } \\
\text { (month/day/ } \\
\text { year) }\end{array}$ & $\begin{array}{c}\text { Sample } \\
\text { start } \\
\text { time }\end{array}$ & $\begin{array}{c}\text { Clostridium } \\
\text { perfringens, } \\
\text { mCP MF } \\
\text { method } \\
\text { (CFU/100 mL) }\end{array}$ & $\begin{array}{c}\text { Coliphage, } \\
\text { E. coli, } \\
\text { C13 host, } \\
\text { MF method } \\
\text { (PFU/100 mL) }\end{array}$ & $\begin{array}{c}\text { Coliphage, } \\
\text { E. coli, } \\
\text { Famp host, } \\
\text { MF method } \\
\text { (PFU/100 mL) }\end{array}$ & $\begin{array}{c}\text { Escherichia } \\
\text { coli, } \\
\text { defined } \\
\text { substrate } \\
\text { technology } \\
\text { (MPN/100 mL) }\end{array}$ & $\begin{array}{c}\text { Escherichia } \\
\text { coli, } \\
\text { modified } \\
\text { m-TEC MF } \\
\text { method } \\
\text { (CFU/100 mL) }\end{array}$ & $\begin{array}{c}\text { Fecal } \\
\text { coliform, } \\
\text { M-FC MF } \\
\text { (0.7 micron) } \\
\text { method } \\
\text { (CFU/100 mL) }\end{array}$ & $\begin{array}{c}\text { Total } \\
\text { coliform, } \\
\text { defined } \\
\text { substrate } \\
\text { technology } \\
\text { (MPN/100 mL) }\end{array}$ & $\begin{array}{c}\text { Total } \\
\text { coliform, } \\
\text { LES Endo } \\
\text { method } \\
\text { (CFU/100 mL) }\end{array}$ & $\begin{array}{c}\text { Total } \\
\text { coliform } \\
\text { (CFU/100 mL) }\end{array}$ & $\begin{array}{c}\text { Total } \\
\text { coliform, } \\
\text { water, } \\
\text { m-ColiBlue } \\
\text { method } \\
\text { (CFU/100 mL) }\end{array}$ \\
\hline \multicolumn{12}{|c|}{ RB1-MS deep-Continued } \\
\hline $5 / 6 / 2009$ & 1151 & -- & -- & -- & $<1$ & -- & $<1$ & $<1$ & $<1$ & -- & -- \\
\hline $5 / 20 / 2009$ & 1140 & $<1$ & $<1$ & $<1$ & -- & $<1$ & $<1$ & -- & -- & $<1$ & -- \\
\hline $5 / 20 / 2009$ & 1141 & -- & -- & -- & $<1$ & -- & $<1$ & $<1$ & $<1$ & -- & -- \\
\hline $6 / 25 / 2009$ & 1145 & $<1$ & $<1$ & $<1$ & -- & -- & -- & -- & -- & -- & -- \\
\hline $6 / 25 / 2009$ & 1146 & -- & -- & -- & $<1$ & -- & $<1$ & $<1$ & $<1$ & -- & -- \\
\hline 7/8/2009 & 1205 & $<1$ & $<1$ & $<1$ & -- & -- & -- & -- & -- & -- & -- \\
\hline 7/8/2009 & 1206 & -- & -- & -- & $<1$ & -- & $<1$ & $>200$ & $<1$ & -- & -- \\
\hline $7 / 13 / 2009$ & 1155 & $<1$ & $<1$ & $<1$ & -- & -- & -- & -- & -- & -- & -- \\
\hline $7 / 13 / 2009$ & 1156 & -- & -- & -- & $<1$ & -- & $<1$ & 37 & $<1$ & -- & -- \\
\hline $7 / 20 / 2009$ & 1240 & $<1$ & $<1$ & $<1$ & -- & $<1$ & $<1$ & -- & -- & -- & E8 \\
\hline $7 / 20 / 2009$ & 1241 & -- & -- & -- & $<1$ & -- & $<1$ & 15 & $<1$ & -- & -- \\
\hline $8 / 18 / 2009$ & 1145 & $<1$ & $<1$ & $<1$ & -- & -- & -- & -- & -- & -- & -- \\
\hline 8/18/2009 & 1146 & -- & -- & -- & $<1$ & -- & $<1$ & 2 & 1 & -- & -- \\
\hline $11 / 18 / 2009$ & 1135 & $<1$ & $<1$ & $<1$ & -- & $<1$ & $<1$ & -- & -- & -- & $<1$ \\
\hline $11 / 18 / 2009$ & 1136 & -- & -- & -- & $<1$ & -- & $<1$ & 2 & $<1$ & -- & -- \\
\hline $3 / 1 / 2010$ & 1255 & $<1$ & $<1$ & $<1$ & -- & $<1$ & $<1$ & -- & -- & $<1$ & -- \\
\hline $3 / 1 / 2010$ & 1256 & -- & -- & -- & $<1$ & -- & $<1$ & $<1$ & $<1$ & -- & -- \\
\hline \multicolumn{12}{|c|}{ RB1-PMS shallow } \\
\hline $2 / 2 / 2009$ & 1035 & $<1$ & $<1$ & $<1$ & -- & -- & -- & -- & -- & -- & -- \\
\hline $2 / 2 / 2009$ & 1036 & -- & -- & -- & $<1$ & -- & $<1$ & $<1$ & $<1$ & -- & -- \\
\hline $3 / 26 / 2009$ & 1115 & $<1$ & $<1$ & $<1$ & -- & -- & -- & -- & -- & -- & -- \\
\hline $3 / 26 / 2009$ & 1116 & -- & -- & -- & $<1$ & -- & $<1$ & 1 & $<1$ & -- & -- \\
\hline $4 / 4 / 2009$ & 1005 & $<1$ & $<1$ & $<1$ & -- & $<1$ & $<1$ & -- & -- & E23 & -- \\
\hline 4/8/2009 & 1005 & $<1$ & 14 & $<1$ & -- & -- & -- & -- & -- & -- & -- \\
\hline 4/8/2009 & 1006 & -- & -- & -- & -- & -- & $<1$ & -- & $<1$ & -- & -- \\
\hline $4 / 15 / 2009$ & 1045 & $<1$ & 9 & $<1$ & -- & -- & -- & -- & -- & -- & -- \\
\hline $4 / 15 / 2009$ & 1046 & -- & -- & -- & $<1$ & -- & $<1$ & 19 & 1 & -- & -- \\
\hline $4 / 18 / 2009$ & 1010 & $<1$ & 1 & $<1$ & -- & $<1$ & $<1$ & -- & -- & E10 & -- \\
\hline $5 / 6 / 2009$ & 1015 & $<1$ & 2 & $<1$ & -- & -- & -- & -- & -- & -- & -- \\
\hline $5 / 6 / 2009$ & 1016 & -- & -- & -- & $<1$ & -- & $<1$ & 1 & 18 & -- & -- \\
\hline
\end{tabular}


Table 6. Summary of bacterial and viral indicator data from water samples collected as part of the Equus Beds Experimental Passive Recharge Project at RB1, 2009-2010.Continued

[mCP, membrane filtration Clostridum perfringens agar; MF, membrane filter; $\mathrm{CFU} / 100 \mathrm{~mL}$, colony forming units per 100 milliliters; E. coli, Escherichia coli; C13, E. coli culture resistant to naladixic acid and used to detect somatic coliphages; PFU/100 milliliters, plaque forming units per 100 milliliters; Famp, E. coli culture resistant to ampicillin and streptomycin and used to detect male-specific coliphages; MPN/100 mL, most probable number per 100 milliliters; m-TEC, membrane-thermotolerant Escherichia coli; M-FC, membrane method fecal coliform; LES, Lawrence Experiment Station;

,-- not determined or not applicable; <, less than; $\mathrm{E}^{* *}$, estimated; >, greater than]

\begin{tabular}{|c|c|c|c|c|c|c|c|c|c|c|c|}
\hline $\begin{array}{c}\text { Date of } \\
\text { sample } \\
\text { collection } \\
\text { (month/day/ } \\
\text { year) }\end{array}$ & $\begin{array}{c}\text { Sample } \\
\text { start } \\
\text { time }\end{array}$ & $\begin{array}{c}\text { Clostridium } \\
\text { perfringens, } \\
\text { mCP MF } \\
\text { method } \\
\text { (CFU/100 mL) }\end{array}$ & $\begin{array}{c}\text { Coliphage, } \\
\text { E. coli, } \\
\text { C13 host, } \\
\text { MF method } \\
\text { (PFU/100 mL) }\end{array}$ & $\begin{array}{l}\text { Coliphage, } \\
\text { E. coli, } \\
\text { Famp host, } \\
\text { MF method } \\
\text { (PFU/100 mL) }\end{array}$ & $\begin{array}{c}\text { Escherichia } \\
\text { coli, } \\
\text { defined } \\
\text { substrate } \\
\text { technology } \\
\text { (MPN/100 mL) }\end{array}$ & $\begin{array}{c}\text { Escherichia } \\
\text { coli, } \\
\text { modified } \\
\text { m-TEC MF } \\
\text { method } \\
\text { (CFU/100 mL) }\end{array}$ & $\begin{array}{c}\text { Fecal } \\
\text { coliform, } \\
\text { M-FC MF } \\
\text { (0.7 micron) } \\
\text { method } \\
\text { (CFU/100 mL) }\end{array}$ & $\begin{array}{c}\text { Total } \\
\text { coliform, } \\
\text { defined } \\
\text { substrate } \\
\text { technology } \\
\text { (MPN/100 mL) }\end{array}$ & $\begin{array}{c}\text { Total } \\
\text { coliform, } \\
\text { LES Endo } \\
\text { method } \\
\text { (CFU/100 mL) }\end{array}$ & $\begin{array}{c}\text { Total } \\
\text { coliform } \\
\text { (CFU/100 mL) }\end{array}$ & $\begin{array}{c}\text { Total } \\
\text { coliform, } \\
\text { water, } \\
\text { m-ColiBlue } \\
\text { method } \\
\text { (CFU/100 mL) }\end{array}$ \\
\hline
\end{tabular}

\begin{tabular}{|c|c|c|c|c|c|c|c|c|c|c|c|}
\hline \multicolumn{12}{|c|}{ RB1-PMS shallow-Continued } \\
\hline $5 / 20 / 2009$ & 1020 & $<1$ & $<1$ & $<1$ & -- & $<1$ & $<1$ & -- & -- & $<1$ & -- \\
\hline $5 / 20 / 2009$ & 1021 & -- & -- & -- & $<1$ & -- & $<1$ & $<1$ & $<1$ & -- & -- \\
\hline 7/8/2009 & 1125 & $<1$ & $<1$ & $<1$ & -- & -- & -- & -- & -- & -- & -- \\
\hline 7/8/2009 & 1126 & -- & -- & -- & $<1$ & -- & $<1$ & $>200$ & 100 & -- & -- \\
\hline $7 / 13 / 2009$ & 1015 & $<1$ & $<1$ & $<1$ & -- & $<1$ & E3 & -- & -- & -- & -- \\
\hline $7 / 13 / 2009$ & 1016 & -- & -- & -- & $<1$ & -- & $<1$ & $>2,400$ & -- & -- & -- \\
\hline $7 / 20 / 2009$ & 1025 & $<1$ & 40 & $<1$ & -- & E1 & $<1$ & -- & -- & -- & $\mathrm{E} 2,000$ \\
\hline $7 / 20 / 2009$ & 1026 & -- & -- & -- & $<1$ & -- & $<1$ & $>200$ & $<1$ & -- & - \\
\hline $8 / 18 / 2009$ & 1010 & $<1$ & $<1$ & $<1$ & -- & -- & -- & -- & -- & -- & -- \\
\hline $8 / 18 / 2009$ & 1011 & -- & -- & -- & $<1$ & -- & $<1$ & 1 & 1 & -- & -- \\
\hline $11 / 17 / 2009$ & 0950 & $<1$ & $<1$ & $<1$ & -- & $<1$ & $<1$ & -- & -- & -- & 20 \\
\hline $11 / 17 / 2009$ & 0951 & -- & -- & -- & $<1$ & -- & $<1$ & 2 & 4 & -- & -- \\
\hline $3 / 2 / 2010$ & 1045 & $<1$ & $<1$ & $<1$ & -- & $<1$ & $<1$ & -- & -- & $<1$ & -- \\
\hline $3 / 2 / 2010$ & 1046 & -- & -- & -- & $<1$ & -- & $<1$ & $<1$ & $<1$ & -- & -- \\
\hline $3 / 2 / 2010$ & 1050 & E1 & $<1$ & $<1$ & -- & $<1$ & $<1$ & -- & -- & $<1$ & -- \\
\hline $3 / 2 / 2010$ & 1051 & -- & -- & -- & $<1$ & -- & $<1$ & $<1$ & $<1$ & -- & -- \\
\hline \multicolumn{12}{|c|}{ RB1-PMS deep } \\
\hline $1 / 22 / 2009$ & 1300 & -- & -- & -- & -- & $<1$ & $<1$ & -- & -- & E1 & -- \\
\hline $2 / 2 / 2009$ & 1205 & $<1$ & $<1$ & $<1$ & -- & -- & -- & -- & -- & -- & -- \\
\hline $2 / 2 / 2009$ & 1206 & -- & -- & -- & $<1$ & -- & $<1$ & $<1$ & $<1$ & -- & -- \\
\hline $3 / 26 / 2009$ & 1240 & $<1$ & $<1$ & $<1$ & -- & -- & -- & -- & -- & -- & -- \\
\hline $3 / 26 / 2009$ & 1241 & -- & -- & -- & $<1$ & -- & $<1$ & $<1$ & $<1$ & -- & -- \\
\hline $4 / 4 / 2009$ & 1130 & $<1$ & $<1$ & $<1$ & -- & $<1$ & $<1$ & -- & -- & 40 & -- \\
\hline $4 / 8 / 2009$ & 1130 & $<1$ & 11 & $<1$ & -- & -- & -- & -- & -- & -- & -- \\
\hline 4/8/2009 & 1131 & -- & -- & -- & $<1$ & -- & $<1$ & 21 & $<1$ & -- & -- \\
\hline $4 / 15 / 2009$ & 1215 & $<1$ & 8 & $<1$ & -- & -- & -- & -- & -- & -- & -- \\
\hline $4 / 15 / 2009$ & 1216 & -- & -- & -- & $<1$ & -- & $<1$ & 8 & 3 & -- & -- \\
\hline $4 / 18 / 2009$ & 1145 & $<1$ & 1 & $<1$ & -- & $<1$ & $<1$ & -- & -- & E9 & -- \\
\hline $5 / 6 / 2009$ & 1140 & $<1$ & 1 & $<1$ & -- & -- & -- & -- & -- & -- & -- \\
\hline $5 / 6 / 2009$ & 1141 & -- & -- & -- & $<1$ & -- & $<1$ & 1 & 5 & -- & -- \\
\hline
\end{tabular}


Table 6. Summary of bacterial and viral indicator data from water samples collected as part of the Equus Beds Experimental Passive Recharge Project at RB1, 2009-2010.Continued

[mCP, membrane filtration Clostridum perfringens agar; MF, membrane filter; CFU/100 mL, colony forming units per 100 milliliters; E. coli, Escherichia coli; C13, E. coli culture resistant to naladixic acid and used to detect somatic coliphages; PFU/100 milliliters, plaque forming units per 100 milliliters; Famp, E. coli culture resistant to ampicillin and streptomycin and used to detect male-specific coliphages; MPN/100 mL, most probable number per 100 milliliters; m-TEC, membrane-thermotolerant Escherichia coli; M-FC, membrane method fecal coliform; LES, Lawrence Experiment Station;

,-- not determined or not applicable; $<$, less than; $\mathrm{E}^{* *}$, estimated; >, greater than]

\begin{tabular}{|c|c|c|c|c|c|c|c|c|c|c|c|}
\hline $\begin{array}{c}\text { Date of } \\
\text { sample } \\
\text { collection } \\
\text { (month/day/ } \\
\text { year) }\end{array}$ & $\begin{array}{c}\text { Sample } \\
\text { start } \\
\text { time }\end{array}$ & $\begin{array}{c}\text { Clostridium } \\
\text { perfringens, } \\
\text { mCP MF } \\
\text { method } \\
\text { (CFU/100 mL) }\end{array}$ & $\begin{array}{c}\text { Coliphage, } \\
\text { E. coli, } \\
\text { C13 host, } \\
\text { MF method } \\
\text { (PFU/100 mL) }\end{array}$ & $\begin{array}{c}\text { Coliphage, } \\
\text { E. coli, } \\
\text { Famp host, } \\
\text { MF method } \\
\text { (PFU/100 mL) }\end{array}$ & $\begin{array}{c}\text { Escherichia } \\
\text { coli, } \\
\text { defined } \\
\text { substrate } \\
\text { technology } \\
\text { (MPN/100 mL) }\end{array}$ & $\begin{array}{c}\text { Escherichia } \\
\text { coli, } \\
\text { modified } \\
\text { m-TEC MF } \\
\text { method } \\
\text { (CFU/100 mL) }\end{array}$ & $\begin{array}{c}\text { Fecal } \\
\text { coliform, } \\
\text { M-FC MF } \\
\text { (0.7 micron) } \\
\text { method } \\
\text { (CFU/100 mL) }\end{array}$ & $\begin{array}{c}\text { Total } \\
\text { coliform, } \\
\text { defined } \\
\text { substrate } \\
\text { technology } \\
\text { (MPN/100 mL) }\end{array}$ & $\begin{array}{c}\text { Total } \\
\text { coliform, } \\
\text { LES Endo } \\
\text { method } \\
\text { (CFU/100 mL) }\end{array}$ & $\begin{array}{c}\text { Total } \\
\text { coliform } \\
\text { (CFU/100 mL) }\end{array}$ & $\begin{array}{c}\text { Total } \\
\text { coliform, } \\
\text { water, } \\
\text { m-ColiBlue } \\
\text { method } \\
\text { (CFU/100 mL) }\end{array}$ \\
\hline \multicolumn{12}{|c|}{ RB1-PMS deep—Continued } \\
\hline $5 / 20 / 2009$ & 1150 & $<1$ & $<1$ & $<1$ & -- & $<1$ & $<1$ & -- & -- & E1 & -- \\
\hline $5 / 20 / 2009$ & 1151 & -- & -- & -- & $<1$ & -- & $<1$ & $<1$ & 1 & -- & -- \\
\hline $7 / 8 / 2009$ & 1005 & $<1$ & $<1$ & $<1$ & -- & -- & -- & -- & -- & -- & -- \\
\hline 7/8/2009 & 1006 & -- & -- & -- & $<1$ & -- & $<1$ & $>200$ & 12 & -- & -- \\
\hline $7 / 13 / 2009$ & 1140 & $<1$ & $<1$ & $<1$ & -- & $<1$ & $<1$ & -- & -- & -- & -- \\
\hline $7 / 13 / 2009$ & 1141 & -- & -- & -- & $<1$ & -- & $<1$ & 690 & -- & -- & -- \\
\hline $7 / 20 / 2009$ & 1200 & $<1$ & $<1$ & $<1$ & -- & $<1$ & $<1$ & -- & -- & -- & E37 \\
\hline $7 / 20 / 2009$ & 1201 & -- & -- & -- & $<1$ & -- & $<1$ & 43 & $<1$ & -- & -- \\
\hline $8 / 18 / 2009$ & 1145 & $<1$ & $<1$ & $<1$ & -- & -- & -- & -- & -- & -- & -- \\
\hline 8/18/2009 & 1146 & -- & -- & -- & $<1$ & -- & $<1$ & 8 & 2 & -- & -- \\
\hline $11 / 17 / 2009$ & 1120 & $<1$ & $<1$ & $<1$ & -- & $<1$ & E1 & -- & -- & -- & E7 \\
\hline $11 / 17 / 2009$ & 1121 & -- & -- & -- & $<1$ & -- & $<1$ & 6 & 6 & -- & -- \\
\hline $3 / 2 / 2010$ & 1255 & $<1$ & $<1$ & $<1$ & -- & $<1$ & $<1$ & -- & -- & E120 & -- \\
\hline $3 / 2 / 2010$ & 1256 & -- & -- & -- & $<1$ & -- & $<1$ & 16 & -- & -- & -- \\
\hline $3 / 22 / 2010$ & 1025 & -- & -- & -- & -- & $<1$ & $<1$ & -- & -- & -- & $<1$ \\
\hline $3 / 22 / 2010$ & 1026 & -- & -- & -- & $<1$ & -- & $<1$ & $<1$ & $<1$ & -- & -- \\
\hline \multicolumn{12}{|c|}{ RB1-P shallow } \\
\hline $1 / 21 / 2009$ & 1500 & -- & -- & -- & -- & $<1$ & $<1$ & -- & -- & 59 & -- \\
\hline $2 / 3 / 2009$ & 1015 & E1 & $<1$ & $<1$ & -- & -- & -- & -- & -- & -- & -- \\
\hline $2 / 3 / 2009$ & 1016 & -- & -- & -- & 29 & -- & $<1$ & $<1$ & 1 & -- & -- \\
\hline $2 / 3 / 2009$ & 1020 & $<1$ & $<1$ & $<1$ & -- & -- & -- & -- & -- & -- & -- \\
\hline $2 / 3 / 2009$ & 1021 & -- & -- & -- & 19 & -- & $<1$ & $<1$ & 1 & -- & -- \\
\hline $3 / 25 / 2009$ & 1035 & $<1$ & $<1$ & $<1$ & -- & -- & -- & -- & -- & -- & -- \\
\hline $3 / 25 / 2009$ & 1036 & -- & -- & -- & $<1$ & -- & $<1$ & $<1$ & $<1$ & -- & -- \\
\hline $4 / 4 / 2009$ & 1310 & $<1$ & E46 & $<1$ & -- & E11 & E9 & -- & -- & $>120$ & -- \\
\hline $4 / 4 / 2009$ & 1315 & $<1$ & E63 & E1 & -- & E11 & E9 & -- & -- & $>120$ & -- \\
\hline 4/7/2009 & 1155 & E1 & 32 & 1 & -- & -- & -- & -- & -- & -- & -- \\
\hline $4 / 7 / 2009$ & 1156 & -- & -- & -- & $<1$ & -- & 1 & $>200$ & 3 & -- & -- \\
\hline $4 / 15 / 2009$ & 1040 & E1 & 110 & $<1$ & -- & -- & -- & -- & -- & -- & -- \\
\hline $4 / 15 / 2009$ & 1041 & -- & -- & -- & $<1$ & -- & $<1$ & $>200$ & 5 & -- & -- \\
\hline
\end{tabular}


Table 6. Summary of bacterial and viral indicator data from water samples collected as part of the Equus Beds Experimental Passive Recharge Project at RB1, 2009-2010.Continued

[mCP, membrane filtration Clostridum perfringens agar; MF, membrane filter; CFU/100 mL, colony forming units per 100 milliliters; E. coli, Escherichia coli; C13, E. coli culture resistant to naladixic acid and used to detect somatic coliphages; PFU/100 milliliters, plaque forming units per 100 milliliters; Famp, E. coli culture resistant to ampicillin and streptomycin and used to detect male-specific coliphages; MPN/100 mL, most probable number per 100 milliliters; m-TEC, membrane-thermotolerant Escherichia coli; M-FC, membrane method fecal coliform; LES, Lawrence Experiment Station;

,-- not determined or not applicable; $<$, less than; $\mathrm{E}^{* *}$, estimated; $>$, greater than]

\begin{tabular}{|c|c|c|c|c|c|c|c|c|c|c|c|}
\hline $\begin{array}{c}\text { Date of } \\
\text { sample } \\
\text { collection } \\
\text { (month/day/ } \\
\text { year) }\end{array}$ & $\begin{array}{c}\text { Sample } \\
\text { start } \\
\text { time }\end{array}$ & $\begin{array}{c}\text { Clostridium } \\
\text { perfringens, } \\
\text { mCP MF } \\
\text { method } \\
\text { (CFU/100 mL) }\end{array}$ & $\begin{array}{c}\text { Coliphage, } \\
\text { E. coli, } \\
\text { C13 host, } \\
\text { MF method } \\
\text { (PFU/100 mL) }\end{array}$ & $\begin{array}{l}\text { Coliphage, } \\
\text { E. coli, } \\
\text { Famp host, } \\
\text { MF method } \\
\text { (PFU/100 mL) }\end{array}$ & $\begin{array}{c}\text { Escherichia } \\
\text { coli, } \\
\text { defined } \\
\text { substrate } \\
\text { technology } \\
\text { (MPN/100 mL) }\end{array}$ & $\begin{array}{c}\text { Escherichia } \\
\text { coli, } \\
\text { modified } \\
\text { m-TEC MF } \\
\text { method } \\
\text { (CFU/100 mL) }\end{array}$ & $\begin{array}{c}\text { Fecal } \\
\text { coliform, } \\
\text { M-FC MF } \\
\text { (0.7 micron) } \\
\text { method } \\
\text { (CFU/100 mL) }\end{array}$ & $\begin{array}{c}\text { Total } \\
\text { coliform, } \\
\text { defined } \\
\text { substrate } \\
\text { technology } \\
\text { (MPN/100 mL) }\end{array}$ & $\begin{array}{c}\text { Total } \\
\text { coliform, } \\
\text { LES Endo } \\
\text { method } \\
\text { (CFU/100 mL) }\end{array}$ & $\begin{array}{c}\text { Total } \\
\text { coliform } \\
\text { (CFU/100 mL) }\end{array}$ & $\begin{array}{c}\text { Total } \\
\text { coliform, } \\
\text { water, } \\
\text { m-ColiBlue } \\
\text { method } \\
\text { (CFU/100 mL) }\end{array}$ \\
\hline
\end{tabular}

\begin{tabular}{|c|c|c|c|c|c|c|c|c|c|c|c|}
\hline \multicolumn{12}{|c|}{ RB1-P shallow-Continued } \\
\hline $4 / 18 / 2009$ & 1010 & E1 & 3 & $<1$ & -- & $\mathrm{E} 4$ & $<1$ & -- & -- & E14 & -- \\
\hline $5 / 4 / 2009$ & 1225 & $<1$ & $<1$ & $<1$ & -- & -- & -- & -- & -- & -- & -- \\
\hline $5 / 4 / 2009$ & 1226 & -- & -- & -- & $<1$ & -- & $<1$ & 6 & 1 & -- & -- \\
\hline $5 / 19 / 2009$ & 1145 & $<1$ & $<1$ & $<1$ & -- & E2 & E2 & -- & -- & E4 & -- \\
\hline $5 / 19 / 2009$ & 1146 & -- & -- & -- & $<1$ & -- & $<1$ & 11 & 1 & -- & -- \\
\hline $8 / 17 / 2009$ & 1050 & E1 & $<1$ & $<1$ & -- & -- & -- & -- & -- & -- & -- \\
\hline $8 / 17 / 2009$ & 1051 & -- & -- & -- & $<1$ & -- & $<1$ & $>200$ & 10 & -- & -- \\
\hline 11/16/2009 & 1015 & $<1$ & $<1$ & $<1$ & -- & $<1$ & $<1$ & -- & -- & -- & $<1$ \\
\hline $11 / 16 / 2009$ & 1016 & -- & -- & -- & $<1$ & -- & $<1$ & $<1$ & $<1$ & -- & -- \\
\hline $3 / 3 / 2010$ & 1020 & $<1$ & $<1$ & $<1$ & -- & $<1$ & $<1$ & -- & -- & $<1$ & -- \\
\hline $3 / 3 / 2010$ & 1021 & -- & -- & -- & $<1$ & -- & $<1$ & $<1$ & $<1$ & -- & -- \\
\hline \multicolumn{12}{|c|}{ RB1-P deep } \\
\hline $2 / 3 / 2009$ & 1150 & $<1$ & $<1$ & $<1$ & -- & -- & -- & -- & -- & -- & -- \\
\hline $2 / 3 / 2009$ & 1151 & -- & -- & -- & 22 & -- & $<1$ & $<1$ & 4 & -- & -- \\
\hline $3 / 25 / 2009$ & 1205 & $<1$ & $<1$ & $<1$ & -- & -- & -- & -- & -- & -- & -- \\
\hline $3 / 25 / 2009$ & 1206 & -- & -- & -- & $<1$ & -- & $<1$ & 32 & $<1$ & -- & -- \\
\hline $4 / 4 / 2009$ & 1440 & $<1$ & E59 & $<1$ & -- & E13 & E11 & -- & -- & $>120$ & -- \\
\hline 4/7/2009 & 1320 & E1 & 40 & $<1$ & -- & -- & -- & -- & -- & -- & -- \\
\hline 4/7/2009 & 1321 & -- & -- & -- & $<1$ & -- & 2 & $>200$ & 14 & -- & -- \\
\hline $4 / 15 / 2009$ & 1210 & E1 & 100 & $<1$ & -- & -- & -- & -- & -- & -- & -- \\
\hline $4 / 15 / 2009$ & 1211 & -- & -- & -- & 2 & -- & 1 & $>200$ & 8 & -- & -- \\
\hline 4/18/2009 & 1130 & E1 & 1 & $<1$ & -- & E4 & $<1$ & -- & -- & E12 & -- \\
\hline $5 / 4 / 2009$ & 1335 & $<1$ & 2 & $<1$ & -- & -- & -- & -- & -- & -- & -- \\
\hline $5 / 4 / 2009$ & 1336 & -- & -- & -- & $<1$ & -- & $<1$ & 5 & 1 & -- & -- \\
\hline $5 / 19 / 2009$ & 1300 & $<1$ & $<1$ & $<1$ & -- & $<1$ & $<1$ & -- & -- & E27 & -- \\
\hline $5 / 19 / 2009$ & 1301 & -- & -- & -- & $<1$ & -- & $<1$ & 11 & $<1$ & -- & -- \\
\hline 7/9/2009 & 1055 & $<1$ & $<1$ & $<1$ & -- & $<1$ & $<1$ & -- & -- & 17 & -- \\
\hline 7/9/2009 & 1056 & -- & -- & -- & $<1$ & -- & $<1$ & 4 & $<1$ & -- & -- \\
\hline $7 / 13 / 2009$ & 1235 & $<1$ & $<1$ & $<1$ & -- & $<1$ & $<1$ & -- & -- & E10 & -- \\
\hline $7 / 13 / 2009$ & 1236 & -- & -- & -- & $<1$ & -- & $<1$ & 5 & $<1$ & -- & -- \\
\hline
\end{tabular}


Table 6. Summary of bacterial and viral indicator data from water samples collected as part of the Equus Beds Experimental Passive Recharge Project at RB1, 2009-2010.Continued

[mCP, membrane filtration Clostridum perfringens agar; MF, membrane filter; CFU/100 mL, colony forming units per 100 milliliters; E. coli, Escherichia coli; C13, E. coli culture resistant to naladixic acid and used to detect somatic coliphages; PFU/100 milliliters, plaque forming units per 100 milliliters; Famp, E. coli culture resistant to ampicillin and streptomycin and used to detect male-specific coliphages; MPN/100 mL, most probable number per 100 milliliters; m-TEC, membrane-thermotolerant Escherichia coli; M-FC, membrane method fecal coliform; LES, Lawrence Experiment Station;

-- , not determined or not applicable; <, less than; $E^{* *}$, estimated; >, greater than]

\begin{tabular}{|c|c|c|c|c|c|c|c|c|c|c|c|}
\hline $\begin{array}{c}\text { Date of } \\
\text { sample } \\
\text { collection } \\
\text { (month/day/ } \\
\text { year) }\end{array}$ & $\begin{array}{c}\text { Sample } \\
\text { start } \\
\text { time }\end{array}$ & $\begin{array}{c}\text { Clostridium } \\
\text { perfringens, } \\
\text { mCP MF } \\
\text { method } \\
\text { (CFU/100 mL) }\end{array}$ & $\begin{array}{c}\text { Coliphage, } \\
\text { E. coli, } \\
\text { C13 host, } \\
\text { MF method } \\
\text { (PFU/100 mL) }\end{array}$ & $\begin{array}{c}\text { Coliphage, } \\
\text { E. coli, } \\
\text { Famp host, } \\
\text { MF method } \\
\text { (PFU/100 mL) }\end{array}$ & $\begin{array}{c}\text { Escherichia } \\
\text { coli, } \\
\text { defined } \\
\text { substrate } \\
\text { technology } \\
\text { (MPN/100 mL) }\end{array}$ & $\begin{array}{c}\text { Escherichia } \\
\text { coli, } \\
\text { modified } \\
\text { m-TEC MF } \\
\text { method } \\
\text { (CFU/100 mL) }\end{array}$ & $\begin{array}{c}\text { Fecal } \\
\text { coliform, } \\
\text { M-FC MF } \\
\text { (0.7 micron) } \\
\text { method } \\
\text { (CFU/100 mL) }\end{array}$ & $\begin{array}{c}\text { Total } \\
\text { coliform, } \\
\text { defined } \\
\text { substrate } \\
\text { technology } \\
\text { (MPN/100 mL) }\end{array}$ & $\begin{array}{c}\text { Total } \\
\text { coliform, } \\
\text { LES Endo } \\
\text { method } \\
\text { (CFU/100 mL) }\end{array}$ & $\begin{array}{c}\text { Total } \\
\text { coliform } \\
\text { (CFU/100 mL) }\end{array}$ & $\begin{array}{c}\text { Total } \\
\text { coliform, } \\
\text { water, } \\
\text { m-ColiBlue } \\
\text { method } \\
\text { (CFU/100 mL) }\end{array}$ \\
\hline \multicolumn{12}{|c|}{ RB1-P deep-Continued } \\
\hline $7 / 20 / 2009$ & 1000 & $<1$ & $<1$ & $<1$ & -- & $<1$ & $<1$ & -- & -- & -- & E6 \\
\hline $7 / 20 / 2009$ & 1001 & -- & -- & -- & $<1$ & -- & 1 & 3 & 1 & -- & -- \\
\hline $8 / 12 / 2009$ & 1020 & $<1$ & $<1$ & $<1$ & -- & $<1$ & $<1$ & -- & -- & -- & E4 \\
\hline $8 / 12 / 2009$ & 1021 & -- & -- & -- & $<1$ & -- & $<1$ & $<1$ & 1 & -- & -- \\
\hline $8 / 17 / 2009$ & 1210 & $<1$ & $<1$ & $<1$ & -- & -- & -- & -- & -- & -- & -- \\
\hline $8 / 17 / 2009$ & 1211 & -- & -- & -- & $<1$ & -- & $<1$ & 74 & 6 & -- & -- \\
\hline $11 / 16 / 2009$ & 1125 & $<1$ & $<1$ & $<1$ & -- & $<1$ & $<1$ & -- & -- & -- & $<1$ \\
\hline $11 / 16 / 2009$ & 1126 & -- & -- & -- & $<1$ & -- & $<1$ & $<1$ & $<1$ & -- & -- \\
\hline $3 / 3 / 2010$ & 1135 & $<1$ & $<1$ & $<1$ & -- & $<1$ & $<1$ & -- & -- & $<1$ & -- \\
\hline $3 / 3 / 2010$ & 1136 & -- & -- & -- & $<1$ & -- & $<1$ & $<1$ & $<1$ & -- & -- \\
\hline \multicolumn{12}{|c|}{ RB1-TR } \\
\hline $3 / 26 / 2009$ & 1020 & $<1$ & $<1$ & $<1$ & -- & -- & -- & -- & -- & -- & -- \\
\hline $3 / 26 / 2009$ & 1021 & -- & -- & -- & $<1$ & -- & $<1$ & 6 & $<1$ & -- & -- \\
\hline 4/3/2009 & 1350 & $<1$ & 1 & $<1$ & -- & -- & -- & -- & -- & -- & -- \\
\hline $4 / 3 / 2009$ & 1351 & -- & -- & -- & 5 & -- & 1 & $>200$ & 7 & -- & -- \\
\hline $4 / 7 / 2009$ & 1000 & $<1$ & 36 & 2 & -- & -- & -- & -- & -- & -- & -- \\
\hline 4/7/2009 & 1001 & -- & -- & -- & 1 & -- & 2 & 370 & 4 & -- & -- \\
\hline 4/7/2009 & 1005 & 1 & 42 & $<1$ & -- & -- & -- & -- & -- & -- & -- \\
\hline 4/7/2009 & 1006 & -- & -- & -- & $<1$ & -- & 4 & 390 & 6 & -- & -- \\
\hline $4 / 14 / 2009$ & 1131 & -- & -- & -- & 2 & -- & 7 & 1,600 & 14 & -- & -- \\
\hline $4 / 14 / 2009$ & 1330 & E1 & 100 & $<1$ & -- & -- & -- & -- & -- & -- & -- \\
\hline $4 / 17 / 2009$ & 1250 & $<1$ & 1 & $<1$ & -- & -- & -- & -- & -- & -- & -- \\
\hline $4 / 17 / 2009$ & 1251 & -- & -- & -- & 1 & -- & $<1$ & 16 & 17 & -- & -- \\
\hline $4 / 23 / 2009$ & 1121 & -- & -- & -- & 1 & -- & 4 & 32 & 16 & -- & -- \\
\hline 4/23/2009 & 1220 & E1 & 1 & $<1$ & -- & E1 & E2 & -- & -- & 120 & -- \\
\hline $4 / 27 / 2009$ & 1140 & E1 & 3 & $<1$ & -- & -- & -- & -- & -- & -- & -- \\
\hline 4/27/2009 & 1141 & -- & -- & -- & 1 & -- & 4 & 200 & 24 & -- & -- \\
\hline $5 / 4 / 2009$ & 1055 & $<1$ & $<1$ & $<1$ & -- & -- & -- & -- & -- & -- & -- \\
\hline $5 / 4 / 2009$ & 1056 & -- & -- & -- & $<1$ & -- & $<1$ & 3 & 1 & -- & -- \\
\hline $5 / 19 / 2009$ & 1020 & $<1$ & $<1$ & $<1$ & -- & $<1$ & $<1$ & -- & -- & 50 & -- \\
\hline $5 / 19 / 2009$ & 1021 & -- & -- & -- & $<1$ & -- & $<1$ & 34 & $<1$ & -- & -- \\
\hline
\end{tabular}


Table 6. Summary of bacterial and viral indicator data from water samples collected as part of the Equus Beds Experimental Passive Recharge Project at RB1, 2009-2010.Continued

[mCP, membrane filtration Clostridum perfringens agar; MF, membrane filter; CFU/100 mL, colony forming units per 100 milliliters; E. coli, Escherichia coli; C13, E. coli culture resistant to naladixic acid and used to detect somatic coliphages; PFU/100 milliliters, plaque forming units per 100 milliliters; Famp, E. coli culture resistant to ampicillin and streptomycin and used to detect male-specific coliphages; MPN/100 mL, most probable number per 100 milliliters; m-TEC, membrane-thermotolerant Escherichia coli; M-FC, membrane method fecal coliform; LES, Lawrence Experiment Station;

,-- not determined or not applicable; $<$, less than; $E^{* *}$, estimated; $>$, greater than]

\begin{tabular}{|c|c|c|c|c|c|c|c|c|c|c|c|}
\hline $\begin{array}{c}\text { Date of } \\
\text { sample } \\
\text { collection } \\
\text { (month/day/ } \\
\text { year) }\end{array}$ & $\begin{array}{c}\text { Sample } \\
\text { start } \\
\text { time }\end{array}$ & $\begin{array}{c}\text { Clostridium } \\
\text { perfringens, } \\
\text { mCP MF } \\
\text { method } \\
\text { (CFU/100 mL) }\end{array}$ & $\begin{array}{c}\text { Coliphage, } \\
\text { E. coli, } \\
\text { C13 host, } \\
\text { MF method } \\
\text { (PFU/100 mL) }\end{array}$ & $\begin{array}{c}\text { Coliphage, } \\
\text { E. coli, } \\
\text { Famp host, } \\
\text { MF method } \\
\text { (PFU/100 mL) }\end{array}$ & $\begin{array}{c}\text { Escherichia } \\
\text { coli, } \\
\text { defined } \\
\text { substrate } \\
\text { technology } \\
\text { (MPN/100 mL) }\end{array}$ & $\begin{array}{c}\text { Escherichia } \\
\text { coli, } \\
\text { modified } \\
\text { m-TEC MF } \\
\text { method } \\
\text { (CFU/100 mL) }\end{array}$ & $\begin{array}{c}\text { Fecal } \\
\text { coliform, } \\
\text { M-FC MF } \\
\text { (0.7 micron) } \\
\text { method } \\
\text { (CFU/100 mL) }\end{array}$ & $\begin{array}{c}\text { Total } \\
\text { coliform, } \\
\text { defined } \\
\text { substrate } \\
\text { technology } \\
\text { (MPN/100 mL) }\end{array}$ & $\begin{array}{c}\text { Total } \\
\text { coliform, } \\
\text { LES Endo } \\
\text { method } \\
\text { (CFU/100 mL) }\end{array}$ & $\begin{array}{c}\text { Total } \\
\text { coliform } \\
\text { (CFU/100 mL) }\end{array}$ & $\begin{array}{c}\text { Total } \\
\text { coliform, } \\
\text { water, } \\
\text { m-ColiBlue } \\
\text { method } \\
\text { (CFU/100 mL) }\end{array}$ \\
\hline \multicolumn{12}{|c|}{ Diverted SW, PAC building } \\
\hline $4 / 3 / 2009$ & 1010 & 130 & 1,300 & 14 & -- & -- & -- & -- & -- & -- & -- \\
\hline $4 / 3 / 2009$ & 1011 & -- & -- & -- & 906 & -- & 2,700 & 24,196 & 2,300 & -- & -- \\
\hline $4 / 14 / 2009$ & 1010 & 8 & 5,500 & $<1$ & -- & -- & -- & -- & -- & -- & -- \\
\hline $4 / 14 / 2009$ & 1011 & -- & -- & -- & 1,600 & -- & 5,000 & 72,700 & 8,000 & -- & -- \\
\hline $4 / 17 / 2009$ & 0950 & 92 & 2,800 & 2 & -- & -- & 42 & -- & -- & -- & -- \\
\hline $4 / 17 / 2009$ & 0951 & -- & -- & -- & 473 & -- & -- & 6,867 & 1,100 & -- & -- \\
\hline
\end{tabular}

${ }^{* *}$ Values may be reported as estimated (E) if values are out of instrument calibration range, data quantification was not performed according to method specific criteria, or deviation for the standard operating procedure was required. Values are considered detections. (Childress and others, 1999). 
Table 7. Summary of iron-related bacteria data and sulfate-reducing bacteria data from biotester analysis of water samples collected as part of the Equus Beds Passive Recharge Project at RB1, 2009-2010.

[IRB, iron-related bacteria; $\mathrm{CFU} / \mathrm{mL}$, colony forming units per 100 milliliters; $\mathrm{SRB}$, sulfate-reducing bacteria; BR, brown ring; <, less than; N/A, non-aggressive; FO, foam; RC, red cloudy; BA, blackened top and base; BC, brown cloudy; BT, blackened top; $\mathrm{BB}$, blackened base; GC, green cloudy; BL, black liquid; --, not determined or not applicable]

\begin{tabular}{|c|c|c|c|c|c|}
\hline $\begin{array}{c}\text { Date of sample } \\
\text { collection } \\
\text { (month/day/ } \\
\text { year) }\end{array}$ & $\begin{array}{c}\text { Sample } \\
\text { start } \\
\text { time }\end{array}$ & $\begin{array}{c}\text { IRB } \\
\text { Biotester } \\
\text { (CFU/mL) }\end{array}$ & $\begin{array}{c}\text { IRB } \\
\text { Biotester Reaction } \\
\text { Pattern Signature }\end{array}$ & $\begin{array}{c}\text { SRB } \\
\text { Biotester } \\
\text { (CFU/mL) }\end{array}$ & $\begin{array}{c}\text { SRB } \\
\text { Biotester Reaction } \\
\text { Pattern Signature }\end{array}$ \\
\hline \multicolumn{6}{|c|}{ IW-09 shallow } \\
\hline $2 / 10 / 2009$ & 0955 & 150 & $\mathrm{BR}$ & $<200$ & $\mathrm{~N} / \mathrm{A}$ \\
\hline $4 / 2 / 2009$ & 1055 & 35,000 & FO-BR & $<200$ & N/A \\
\hline $4 / 22 / 2009$ & 1020 & 25 & $\mathrm{RC}$ & $<200$ & N/A \\
\hline $6 / 10 / 2009$ & 0955 & 2,300 & $\mathrm{FO}$ & $<200$ & $\mathrm{~N} / \mathrm{A}$ \\
\hline $7 / 14 / 2009$ & 1020 & $<25$ & N/A & $<200$ & N/A \\
\hline $8 / 19 / 2009$ & 1000 & 25 & $\mathrm{BR}$ & 200 & $\mathrm{BA}$ \\
\hline $11 / 17 / 2009$ & 1005 & 9,000 & FO-BR & $<200$ & N/A \\
\hline $3 / 9 / 2010$ & 1010 & 9,000 & FO-BR & $<200$ & $\mathrm{~N} / \mathrm{A}$ \\
\hline \multicolumn{6}{|c|}{ IW-09 deep } \\
\hline $2 / 10 / 2009$ & 1125 & 150 & $\mathrm{BR}$ & $<200$ & N/A \\
\hline $4 / 2 / 2009$ & 1215 & 500 & FO-BC, BR & 5,000 & BT-BA \\
\hline $4 / 22 / 2009$ & 1200 & 150 & FO & $<200$ & $\mathrm{~N} / \mathrm{A}$ \\
\hline $8 / 19 / 2009$ & 1150 & 25 & FO & 200 & $\mathrm{BB}$ \\
\hline $11 / 17 / 2009$ & 1145 & 500 & FO & $<200$ & N/A \\
\hline $3 / 9 / 2010$ & 1155 & 150 & FO-BR & $<200$ & N/A \\
\hline \multicolumn{6}{|c|}{ RB1 source water } \\
\hline $4 / 3 / 2009$ & 1215 & 35,000 & FO-GC, BL & 100,000 & BT-BA \\
\hline $4 / 14 / 2009$ & 1140 & 35,000 & FO-BC-BR/BL & 100,000 & BT-BA \\
\hline $4 / 17 / 2009$ & 1110 & 35,000 & FO-BL-BR & 100,000 & BT-BA \\
\hline \multicolumn{6}{|c|}{ RB1-MN shallow } \\
\hline $2 / 9 / 2009$ & 1020 & 9,000 & FO & 200 & $\mathrm{BB}$ \\
\hline $4 / 1 / 2009$ & 1110 & 9,000 & $\mathrm{FO}$ & 5,000 & BB-BA \\
\hline $4 / 21 / 2009$ & 0955 & 9,000 & FO & 18,000 & BT-BA \\
\hline $6 / 25 / 2009$ & 1000 & 35,000 & FO-BR & 5,000 & BT-BA \\
\hline $7 / 14 / 2009$ & 1025 & $<25$ & N/A & $<200$ & $\mathrm{~N} / \mathrm{A}$ \\
\hline $8 / 19 / 2009$ & 0955 & 35,000 & FO & 18,000 & BT-BA \\
\hline $11 / 18 / 2009$ & 1005 & 35,000 & FO-BR & 18,000 & BT-BA \\
\hline $3 / 8 / 2010$ & 1010 & 9,000 & FO-BR & $<200$ & NA \\
\hline \multicolumn{6}{|c|}{ RB1-MN deep } \\
\hline $2 / 9 / 2009$ & 1150 & 9,000 & $\mathrm{BR}$ & 18,000 & BB-BA \\
\hline $4 / 1 / 2009$ & 1240 & 150 & FO & $<200$ & N/A \\
\hline $4 / 21 / 2009$ & 1115 & 500 & FO-GC & 18,000 & BT-BA \\
\hline $6 / 25 / 2009$ & 1200 & 500 & FO-BR & $<200$ & N/A \\
\hline $7 / 14 / 2009$ & 1200 & 25 & FO & 200 & $\mathrm{BB}$ \\
\hline $8 / 19 / 2009$ & 1125 & 2,300 & FO & $<200$ & N/A \\
\hline $11 / 24 / 2009$ & 1130 & 500 & FO-BR & $<200$ & N/A \\
\hline $3 / 8 / 2010$ & 1145 & 25 & $\mathrm{BR}$ & $<200$ & N/A \\
\hline \multicolumn{6}{|c|}{ RB1-MS shallow } \\
\hline $2 / 4 / 2009$ & 1005 & 25 & -- & 100,000 & BT-BA \\
\hline $3 / 4 / 2009$ & 1015 & 2,300 & FO & 200 & $\mathrm{BB}$ \\
\hline $3 / 24 / 2009$ & 1135 & 2,300 & FO & 18,000 & BT-BA \\
\hline $4 / 6 / 2009$ & 1010 & 9,000 & FO & 18,000 & BT-BA \\
\hline $4 / 9 / 2009$ & 1005 & 9,000 & FO & 1,200 & BT-BA \\
\hline $4 / 16 / 2009$ & 1015 & 9,000 & FO & 18,000 & BT-BA \\
\hline $4 / 20 / 2009$ & 1005 & 35,000 & FO & 100,000 & BT-BA \\
\hline $5 / 6 / 2009$ & 1025 & 35,000 & FO-GC & 5,000 & BT-BA \\
\hline $5 / 20 / 2009$ & 1005 & $<25$ & N/A & 100,000 & $\mathrm{BT}$ \\
\hline $6 / 25 / 2009$ & 1000 & 2,300 & BR-FO & 100,000 & BT-BA \\
\hline $7 / 8 / 2009$ & 1020 & 35,000 & FO-GC & 100,000 & BT-BA \\
\hline $7 / 13 / 2009$ & 1015 & 140,000 & FO-GC & 100,000 & BT-BA \\
\hline
\end{tabular}


Table 7. Summary of iron-related bacteria data and sulfate-reducing bacteria data from biotester analysis of water samples collected as part of the Equus Beds Passive Recharge Project at RB1, 2009-2010.-Continued

[IRB, iron-related bacteria; $\mathrm{CFU} / \mathrm{mL}$, colony forming units per 100 milliliters; SRB, sulfate-reducing bacteria; BR, brown ring; <, less than; N/A, non-aggressive; FO, foam; RC, red cloudy; BA, blackened top and base; BC, brown cloudy; BT, blackened top; $\mathrm{BB}$, blackened base; GC, green cloudy; BL, black liquid; --, not determined or not applicable]

\begin{tabular}{|c|c|c|c|c|c|}
\hline $\begin{array}{c}\text { Date of sample } \\
\text { collection } \\
\text { (month/day/ } \\
\text { year) }\end{array}$ & $\begin{array}{c}\text { Sample } \\
\text { start } \\
\text { time }\end{array}$ & $\begin{array}{c}\text { IRB } \\
\text { Biotester } \\
\text { (CFU/mL) }\end{array}$ & $\begin{array}{c}\text { IRB } \\
\text { Biotester Reaction } \\
\text { Pattern Signature }\end{array}$ & $\begin{array}{c}\text { SRB } \\
\text { Biotester } \\
\text { (CFU/mL) }\end{array}$ & $\begin{array}{c}\text { SRB } \\
\text { Biotester Reaction } \\
\text { Pattern Signature }\end{array}$ \\
\hline \multicolumn{6}{|c|}{ RB1-MS shallow-Continued } \\
\hline $7 / 20 / 2009$ & 1015 & 140,000 & FO-BC-BG & 100,000 & BT-BA \\
\hline $8 / 18 / 2009$ & 1010 & 140,000 & FO-BG, BR & 100,000 & BT-BA \\
\hline $11 / 18 / 2009$ & 1005 & 35,000 & FO-BR-GC & 1,200 & BT \\
\hline $3 / 1 / 2010$ & 1130 & 150 & $\mathrm{FO}$ & $<200$ & N/A \\
\hline \multicolumn{6}{|c|}{ RB1-MS deep } \\
\hline $2 / 4 / 2009$ & 1140 & 9,000 & FO & 5,000 & BT-BA \\
\hline $3 / 4 / 2009$ & 1200 & $<25$ & N/A & 500 & BB-BA \\
\hline $3 / 24 / 2009$ & 1305 & 2,300 & FO-BR & 18,000 & BT-BA \\
\hline $4 / 6 / 2009$ & 1140 & 35,000 & FO-BR & 18,000 & BT-BA \\
\hline 4/9/2009 & 1135 & 35,000 & FO-BR & 100,000 & BT-BA \\
\hline $4 / 16 / 2009$ & 1140 & 35,000 & FO-CL-BR & 100,000 & BB-BA \\
\hline $4 / 20 / 2009$ & 1135 & 35,000 & $\mathrm{FO}$ & 100,000 & BT-BA \\
\hline $5 / 6 / 2009$ & 1150 & 35,000 & FO & 5,000 & BT-BA \\
\hline $5 / 20 / 2009$ & 1140 & 35,000 & $\mathrm{FO}$ & $<200$ & N/A \\
\hline $6 / 25 / 2009$ & 1145 & 35,000 & FO-BR-BC, BG-GC & 100,000 & BT-BA \\
\hline $7 / 8 / 2009$ & 1205 & 35,000 & FO-RC & 100,000 & BT-BA \\
\hline $7 / 13 / 2009$ & 1155 & 35,000 & FO-RC & 100,000 & BT-BA \\
\hline $7 / 20 / 2009$ & 1240 & 35,000 & FO-BG, BR-GC & 100,000 & BT-BA \\
\hline $8 / 18 / 2009$ & 1145 & 35,000 & FO-BG-BR & $<200$ & N/A \\
\hline $11 / 18 / 2009$ & 1135 & 35,000 & FO-RC & $<200$ & $\mathrm{~N} / \mathrm{A}$ \\
\hline $3 / 1 / 2010$ & 1255 & $<25$ & $\mathrm{FO}$ & $<200$ & $\mathrm{~N} / \mathrm{A}$ \\
\hline \multicolumn{6}{|c|}{ RB1-PMS shallow } \\
\hline $1 / 22 / 2009$ & 1415 & 500 & $\mathrm{FO}, \mathrm{BR}, \mathrm{BC}$ & 18,000 & BT-BA \\
\hline $2 / 2 / 2009$ & 1035 & 500 & FO & $<200$ & N/A \\
\hline $3 / 26 / 2009$ & 1115 & 35,000 & FO-CL & 100,000 & BT-BA \\
\hline $4 / 4 / 2009$ & 1005 & 35,000 & FO-BR, GC-BL & 700,000 & BT-BA \\
\hline $4 / 8 / 2009$ & 1005 & 35,000 & FO-BR & 700,000 & BT-BA \\
\hline $4 / 15 / 2009$ & 1045 & 9,000 & FO, BC-GC, BR & 5,000 & BT \\
\hline $5 / 6 / 2009$ & 1015 & 35,000 & FO-GC & 100,000 & BT-BA \\
\hline $5 / 20 / 2009$ & 1020 & 9,000 & FO-GC,B R & 5,000 & BT-BA \\
\hline $7 / 8 / 2009$ & 1125 & 9,000 & FO-RC & 100,000 & BT-BA \\
\hline $7 / 13 / 2009$ & 1015 & 9,000 & FO-RC-BL & 700,000 & BT-BA \\
\hline $7 / 20 / 2009$ & 1025 & 9,000 & FO-GC-BL & 100,000 & BT-BA \\
\hline $8 / 18 / 2009$ & 1010 & 2,300 & FO-BC, BG-BR & 200 & $\mathrm{BA}$ \\
\hline $11 / 17 / 2009$ & 0950 & 9,000 & FO-GC & 1,200 & BT-BA \\
\hline $3 / 2 / 2010$ & -- & 35,000 & FO-GC & 18,000 & BT-BA \\
\hline \multicolumn{6}{|c|}{ RB1-PMS deep } \\
\hline $1 / 22 / 2009$ & 1300 & 500 & FO, BR, BC & 1,200 & BA \\
\hline $2 / 2 / 2009$ & 1205 & 2,300 & $\mathrm{FO}, \mathrm{BR}, \mathrm{BC}$ & 18,000 & BA \\
\hline $3 / 26 / 2009$ & 1240 & 35,000 & FO-GC-BL & 700,000 & BT-BA \\
\hline $4 / 4 / 2009$ & 1130 & 35,000 & FO-GC, BR & 100,000 & BT \\
\hline $4 / 8 / 2009$ & 1130 & 35,000 & FO-GC-BL & 5,000 & BT-BA \\
\hline $4 / 15 / 2009$ & 1215 & 35,000 & FO-BC-BR & $<200$ & N/A \\
\hline $4 / 18 / 2009$ & 1145 & 35,000 & FO-RC & $<200$ & N/A \\
\hline $5 / 6 / 2009$ & 1140 & 35,000 & FO-RC-BL & 18,000 & $\mathrm{BT}$ \\
\hline $5 / 20 / 2009$ & 1150 & 35,000 & FO & $<200$ & N/A \\
\hline $7 / 8 / 2009$ & 1005 & 35,000 & FO-RC-BL & 5,000 & BT-BA \\
\hline $7 / 13 / 2009$ & 1140 & 35,000 & FO-RC-BL & 100,000 & BT-BA \\
\hline $7 / 20 / 2009$ & 1200 & 35,000 & FO-BR, BC, BG-BL & 100,000 & BT-BA \\
\hline $8 / 18 / 2009$ & 1145 & 35,000 & FO-BG-BC & 1,200 & $\mathrm{BA}$ \\
\hline
\end{tabular}


Table 7. Summary of iron-related bacteria data and sulfate-reducing bacteria data from biotester analysis of water samples collected as part of the Equus Beds Passive Recharge Project at RB1, 2009-2010._-Continued

[IRB, iron-related bacteria; CFU/mL, colony forming units per 100 milliliters; SRB, sulfate-reducing bacteria; BR, brown ring; <, less than; N/A, non-aggressive; FO, foam; RC, red cloudy; BA, blackened top and base; BC, brown cloudy; BT, blackened top; BB, blackened base; GC, green cloudy; BL, black liquid; --, not determined or not applicable]

\begin{tabular}{|c|c|c|c|c|c|}
\hline $\begin{array}{c}\text { Date of sample } \\
\text { collection } \\
\text { (month/day/ } \\
\text { year) }\end{array}$ & $\begin{array}{l}\text { Sample } \\
\text { start } \\
\text { time }\end{array}$ & $\begin{array}{c}\text { IRB } \\
\text { Biotester } \\
\text { (CFU/mL) }\end{array}$ & $\begin{array}{c}\text { IRB } \\
\text { Biotester Reaction } \\
\text { Pattern Signature }\end{array}$ & $\begin{array}{c}\text { SRB } \\
\text { Biotester } \\
\text { (CFU/mL) }\end{array}$ & $\begin{array}{c}\text { SRB } \\
\text { Biotester Reaction } \\
\text { Pattern Signature }\end{array}$ \\
\hline \multicolumn{6}{|c|}{ RB1-PMS deep-Continued } \\
\hline $11 / 17 / 2009$ & 1120 & 500 & FO-GC & 18,000 & BT-BA \\
\hline $3 / 2 / 2010$ & -- & 35,000 & FO-GC & 100,000 & BT-BA \\
\hline $3 / 22 / 2010$ & 1025 & $<25$ & N/A & 200 & $\mathrm{BB}$ \\
\hline \multicolumn{6}{|c|}{ RB1-P shallow } \\
\hline $1 / 21 / 2009$ & 1500 & 2,300 & FO-BC, BR & 5,000 & BB-BA \\
\hline 2/3/2009 & 1015 & 2,300 & FO-BR, BC & 100,000 & $\mathrm{BA}$ \\
\hline $3 / 25 / 2009$ & 1035 & 35,000 & FO-GC-BL & 700,000 & BT-BA \\
\hline $4 / 4 / 2009$ & 1310 & 35,000 & FO-BC-RC-BR, BL & 700,000 & BT-BA \\
\hline $4 / 7 / 2009$ & 1155 & 35,000 & FO-BG-BR & 18,000 & BT-BA \\
\hline $4 / 15 / 2009$ & 1040 & 35,000 & FO-BR-BG & 500 & $\mathrm{BB}$ \\
\hline $4 / 18 / 2009$ & 1010 & 35,000 & FO-GC & 500 & BA \\
\hline $5 / 4 / 2009$ & 1225 & 35,000 & $\mathrm{FO}$ & 18,000 & BB-BA \\
\hline $5 / 19 / 2009$ & 1145 & 35,000 & FO-RC-BR-BL & 100,000 & BT-BA \\
\hline $8 / 17 / 2009$ & 1050 & 140,000 & FO-BG-BC-GC-BL & $<200$ & N/A \\
\hline $11 / 16 / 2009$ & 1015 & 35,000 & FO-BR-GC & 5,000 & BB-BA \\
\hline $3 / 3 / 2010$ & -- & 35,000 & FO & 200 & $\mathrm{BB}$ \\
\hline \multicolumn{6}{|c|}{ RB1-P deep } \\
\hline $2 / 3 / 2009$ & 1150 & 9,000 & FO-BR, BG & 100,000 & BT-BA \\
\hline $3 / 25 / 2009$ & 1205 & 35,000 & FO-GC-BL & 100,000 & BT-BA \\
\hline $4 / 4 / 2009$ & 1440 & 35,000 & FO-BC-BL & 700,000 & BT-BA \\
\hline $4 / 18 / 2009$ & 1130 & 35,000 & FO-RC & $<200$ & N/A \\
\hline $5 / 4 / 2009$ & 1035 & 35,000 & FO & 100,000 & BT-BA \\
\hline $5 / 19 / 2009$ & 1300 & 35,000 & FO-RC,BR & 100,000 & BT-BA \\
\hline $7 / 9 / 2009$ & 1055 & 35,000 & FO-GC & $<200$ & N/A \\
\hline $7 / 13 / 2009$ & 1235 & 35,000 & FO-GC & 200 & BB-BA \\
\hline $7 / 20 / 2009$ & 1000 & 35,000 & FO-RC-BL & 700,000 & BT-BA \\
\hline $8 / 12 / 2009$ & 1020 & 35,000 & FO-BR-BG-BC & $<200$ & N/A \\
\hline $8 / 17 / 2009$ & 1210 & 140,000 & FO-BG-BC-BR & 200 & BA \\
\hline $11 / 16 / 2009$ & 1125 & 35,000 & FO-GC & 1,200 & BB-BA \\
\hline $3 / 3 / 2010$ & -- & 35,000 & $\mathrm{FO}$ & 200 & $\mathrm{BB}$ \\
\hline \multicolumn{6}{|c|}{ RB1-P TR } \\
\hline $3 / 26 / 2009$ & 1020 & 35,000 & FO-BR-BC & 700,000 & BT-BA \\
\hline $4 / 3 / 2009$ & 1350 & 35,000 & FO-GC-BL & 18,000 & BT-BA \\
\hline $4 / 7 / 2009$ & 1000 & 35,000 & FO-BC-GC-BL & 18,000 & BT-BA \\
\hline $4 / 14 / 2009$ & 1330 & 35,000 & FO-BC-BR & 1,200 & BT-BA \\
\hline $4 / 17 / 2009$ & 1250 & 35,000 & FO-BR,BC & 200 & $\mathrm{BB}$ \\
\hline $4 / 23 / 2009$ & 1220 & 140,000 & FO-GC-RC & 700,000 & BT-BA \\
\hline $4 / 27 / 2009$ & 1140 & 35,000 & FG-GC & 100,000 & BT-BA \\
\hline $5 / 4 / 2009$ & 1055 & 35,000 & FO & 18,000 & BT-BA \\
\hline $5 / 19 / 2009$ & 1020 & 35,000 & FO-RC-BR & $<200$ & N/A \\
\hline \multicolumn{6}{|c|}{ Diverted SW, PAC building } \\
\hline $4 / 3 / 2009$ & 1010 & 35,000 & FO-BC-BL & 700,000 & BT-BA \\
\hline $4 / 14 / 2009$ & 1010 & 35,000 & FO-GC, BG-BL & 100,000 & BT-BA \\
\hline 4/17/2009 & 0950 & 35,000 & FO-BL-BR & 100,000 & $\mathrm{BA}$ \\
\hline
\end{tabular}


Table 8. Summary of major ion data from water samples collected as part of the Equus Beds Experimental Passive Recharge Project at RB1, $2009-2010$.

$\left[\mathrm{mg} / \mathrm{L}\right.$, milligrams per liter; --, not determined or not applicable; $<$, less than; $\mathrm{E}^{* *}$, estimated]

\begin{tabular}{|c|c|c|c|c|c|c|c|c|c|c|c|c|c|c|c|c|}
\hline $\begin{array}{c}\text { Date of } \\
\text { sample } \\
\text { collection } \\
\text { (month/day/ } \\
\text { year) }\end{array}$ & $\begin{array}{c}\text { Sample } \\
\text { start } \\
\text { time }\end{array}$ & $\begin{array}{l}\text { Calcium } \\
\text { (mg/L) }\end{array}$ & $\begin{array}{l}\text { Magnesium } \\
\quad(\mathrm{mg} / \mathrm{L})\end{array}$ & $\begin{array}{l}\text { Potassium } \\
\text { (mg/L) }\end{array}$ & $\begin{array}{c}\text { Sodium } \\
\text { (mg/L) }\end{array}$ & $\begin{array}{l}\text { Bicarbonate, } \\
\text { inflection- } \\
\text { point titration } \\
\text { method } \\
\text { (mg/L) }\end{array}$ & $\begin{array}{c}\text { Bromide } \\
\text { (mg/L) }\end{array}$ & $\begin{array}{c}\text { Carbonate, } \\
\text { inflection- } \\
\text { point titration } \\
\text { method } \\
\text { (mg/L) }\end{array}$ & $\begin{array}{c}\text { Chloride } \\
\text { (mg/L) }\end{array}$ & $\begin{array}{l}\text { Sulfate } \\
\text { (mg/L) }\end{array}$ & $\begin{array}{c}\text { Ammonia } \\
\text { (mg/L) }\end{array}$ & $\begin{array}{l}\text { Nitrate } \\
\text { plus } \\
\text { nitrite } \\
\text { (mg/L) }\end{array}$ & $\begin{array}{l}\text { Nitrate } \\
\text { (mg/L) }\end{array}$ & $\begin{array}{c}\text { Ortho- } \\
\text { phosphate } \\
\text { (mg/L) }\end{array}$ & $\begin{array}{l}\text { Phosphorus } \\
\text { (mg/L) }\end{array}$ & $\begin{array}{c}\text { Organic } \\
\text { carbon } \\
(\mathrm{mg} / \mathrm{L})\end{array}$ \\
\hline \multicolumn{17}{|c|}{ IW-09 shallow } \\
\hline $3 / 19 / 2002$ & 1101 & 65.5 & 12.5 & 3.53 & 45.1 & 170 & 0.1 & 0 & 16 & 86 & 0.06 & 10.8 & 10.8 & 0.215 & 0.1 & -- \\
\hline $6 / 20 / 2002$ & 0936 & 63.5 & 12.7 & 3.47 & 42.4 & 180 & 0.2 & 0 & 16 & 95 & 0.05 & 13.3 & 13.2 & 0.215 & 0.1 & 1.3 \\
\hline $2 / 14 / 2003$ & 1036 & 64.9 & 12.2 & 3.75 & 41.3 & 160 & 0.1 & 0 & 16 & 79 & $<0.03$ & -- & $<0.01$ & 0.276 & 0.15 & -- \\
\hline $6 / 25 / 2003$ & 0856 & 69.9 & 12.9 & 3.71 & 32 & 150 & 0.1 & 0 & 19 & 139 & $<0.03$ & 6.35 & 6.29 & 0.552 & 0.211 & 0.6 \\
\hline $6 / 25 / 2003$ & 0905 & 70.1 & 12.8 & 3.51 & 31.3 & -- & -- & -- & 10.4 & 130 & $<0.04$ & 6.12 & 6.01 & 0.595 & 0.21 & 0.6 \\
\hline $2 / 10 / 2004$ & 1031 & 65 & 12.1 & 3.55 & 34.2 & 150 & 0.1 & 0 & 16 & 104 & $<0.03$ & 9 & 9 & -- & 0.23 & -- \\
\hline $6 / 25 / 2004$ & 0926 & 68.4 & 12.5 & 3.45 & 30.8 & 140 & 0.1 & 0 & 15 & 136 & $<0.03$ & 6.96 & 6.96 & 0.276 & 0.244 & 0.8 \\
\hline $7 / 11 / 2005$ & 1201 & 69.4 & 12.4 & 3.82 & 31.3 & 130 & 0.1 & 0 & 10.5 & 127 & $<0.03$ & 5.06 & 5.06 & 0.736 & 0.247 & -- \\
\hline $6 / 14 / 2006$ & 1046 & 62.5 & 12.2 & 3.44 & 39.3 & 160 & $<0.03$ & 0 & 20.6 & 82.7 & $<0.03$ & 11.4 & 11.4 & 0.491 & 0.091 & -- \\
\hline $6 / 14 / 2006$ & 1050 & 62.4 & 11.8 & 3.22 & 37.8 & -- & -- & -- & 19 & 84.1 & E0.006 & 12.4 & 12.3 & 0.519 & 0.16 & 0.8 \\
\hline $6 / 20 / 2007$ & 1021 & 61.2 & 11.9 & 4 & 28.3 & 140 & 0.1 & 0 & 11 & 110 & 0.05 & 5.62 & 5.62 & 0.705 & 0.227 & 0.71 \\
\hline $6 / 12 / 2008$ & 0941 & 57.6 & 10.8 & 3 & 27.6 & 140 & 0.1 & 0 & $<5$ & 87 & 0.08 & 8.46 & 8.42 & 0.552 & 0.22 & -- \\
\hline 2/10/2009 & 0956 & 58.6 & 10.8 & 3 & 30 & 130 & 0.1 & 0 & 16 & 83 & 0.04 & 6.57 & 6.53 & 0.675 & 0.23 & 0.69 \\
\hline $4 / 2 / 2009$ & 1056 & 55.4 & 10 & 3 & 31.1 & 120 & 0.1 & 0 & 18 & 77 & 0.2 & 5.36 & 5.34 & 0.644 & 0.21 & 0.67 \\
\hline $4 / 22 / 2009$ & 1021 & 56.5 & 10.4 & 3 & 30.1 & 130 & 0.1 & 0 & 18 & 81 & 0.06 & 5.39 & 5.36 & 0.644 & 0.2 & 0.7 \\
\hline $6 / 10 / 2009$ & 0956 & 59.6 & 10.7 & 3 & 25.2 & 130 & 0.1 & 0 & 11 & 100 & $<0.03$ & 3.9 & 3.83 & 0.736 & 0.24 & -- \\
\hline $6 / 10 / 2009$ & 1000 & 56.5 & 10.5 & 3.14 & 24.4 & -- & -- & -- & 13.4 & 104 & $<0.02$ & 4.01 & 3.95 & 0.855 & 0.26 & 1.1 \\
\hline $7 / 14 / 2009$ & 1021 & 60.4 & 10.8 & 3 & 25.8 & 120 & 0.1 & 0 & 12 & 100 & $<0.03$ & 3.81 & 3.74 & 0.705 & 0.36 & 0.71 \\
\hline 8/19/2009 & 1001 & 59 & 10.8 & 3 & 26.9 & 120 & 0.1 & 0 & 14 & 98 & $<0.03$ & 4.62 & 4.55 & 0.736 & 0.26 & 0.63 \\
\hline $11 / 17 / 2009$ & 1006 & 57.9 & 10.5 & 3 & 30.5 & 130 & 0.1 & 0 & 21 & 86 & $<0.03$ & 4.44 & 4.36 & 0.736 & 0.22 & 0.75 \\
\hline 3/9/2010 & 1011 & 55.7 & 9.9 & 3 & 32.2 & 140 & 0.1 & 0 & 19 & 80 & $<0.03$ & 5.42 & 5.34 & 0.644 & 0.19 & 0.68 \\
\hline
\end{tabular}


[mg/L, milligrams per liter; --, not determined or not applicable; <, less than; $\mathrm{E}^{* *}$, estimated]

\begin{tabular}{|c|c|c|c|c|c|c|c|c|c|c|c|c|c|c|c|c|}
\hline $\begin{array}{c}\text { Date of } \\
\text { sample } \\
\text { collection } \\
\text { (month/day/ } \\
\text { year) }\end{array}$ & $\begin{array}{l}\text { Sample } \\
\text { start } \\
\text { time }\end{array}$ & $\begin{array}{c}\text { Calcium } \\
\text { (mg/L) }\end{array}$ & $\begin{array}{l}\text { Magnesium } \\
(\mathrm{mg} / \mathrm{L})\end{array}$ & $\begin{array}{l}\text { Potassium } \\
\text { (mg/L) }\end{array}$ & $\begin{array}{c}\text { Sodium } \\
\text { (mg/L) }\end{array}$ & $\begin{array}{l}\text { Bicarbonate, } \\
\text { inflection- } \\
\text { point titration } \\
\text { method } \\
\text { (mg/L) }\end{array}$ & $\begin{array}{c}\text { Bromide } \\
\text { (mg/L) }\end{array}$ & $\begin{array}{c}\text { Carbonate, } \\
\text { inflection- } \\
\text { point titration } \\
\text { method } \\
\text { (mg/L) }\end{array}$ & $\begin{array}{c}\text { Chloride } \\
\text { (mg/L) }\end{array}$ & $\begin{array}{l}\text { Sulfate } \\
\text { (mg/L) }\end{array}$ & $\begin{array}{c}\text { Ammonia } \\
(\mathrm{mg} / \mathrm{L})\end{array}$ & $\begin{array}{c}\text { Nitrate } \\
\text { plus } \\
\text { nitrite } \\
\text { (mg/L) }\end{array}$ & $\begin{array}{l}\text { Nitrate } \\
\text { (mg/L) }\end{array}$ & $\begin{array}{c}\text { Ortho- } \\
\text { phosphate } \\
\text { (mg/L) }\end{array}$ & $\begin{array}{l}\text { Phosphorus } \\
\text { (mg/L) }\end{array}$ & $\begin{array}{c}\text { Organic } \\
\text { carbon } \\
(\mathrm{mg} / \mathrm{L})\end{array}$ \\
\hline \multicolumn{17}{|c|}{ IW-09 deep } \\
\hline $3 / 19 / 2002$ & 1306 & 57.9 & 8.71 & 2.45 & 38.8 & 240 & 0.1 & 0 & 22 & 25 & 0.26 & 0.02 & 0.02 & 0.429 & 0.21 & -- \\
\hline $6 / 24 / 2002$ & 1046 & 59.7 & 9.17 & 2.67 & 37.9 & 240 & 0.1 & 0 & 31 & 22 & 0.24 & 0.41 & 0.41 & 0.46 & 0.26 & 0.7 \\
\hline $2 / 14 / 2003$ & 1336 & 62.0 & 9.34 & 2.66 & 39.3 & 240 & 0.1 & 0 & 29 & 23 & 0.2 & 0.31 & 0.31 & 0.46 & 0.22 & -- \\
\hline $6 / 25 / 2003$ & 1136 & 58.2 & 8.94 & 2.5 & 38.1 & 240 & 0.1 & 0 & 30 & 25 & 0.2 & 0.03 & 0.03 & 0.552 & 0.212 & 0.5 \\
\hline $6 / 25 / 2003$ & 1145 & 57.4 & 8.66 & 2.33 & 36.3 & -- & -- & -- & 30.5 & 26.2 & 0.21 & $<0.06$ & -- & 0.552 & 0.19 & 0.5 \\
\hline $2 / 10 / 2004$ & 1226 & 67.2 & 10.2 & 2.61 & 39.8 & 240 & 0.1 & 0 & 49 & 27 & 0.17 & $<0.02$ & $<0.01$ & -- & 0.21 & -- \\
\hline $6 / 25 / 2004$ & 1131 & 66.9 & 10 & 2.56 & 40.1 & 230 & 0.1 & 0 & 51 & 31 & 0.22 & 0.13 & 0.13 & 0.46 & 0.226 & 0.6 \\
\hline $7 / 11 / 2005$ & 1031 & 68.1 & 10.1 & 2.74 & 41.9 & 230 & 0.2 & 0 & 47.5 & 31.1 & 0.18 & 0.36 & 0.36 & 0.521 & 0.203 & -- \\
\hline $6 / 14 / 2006$ & 1236 & 66.7 & 10.2 & 2.59 & 39.3 & 230 & 0.2 & 0 & 49.8 & 27.1 & 0.2 & 0.3 & 0.3 & 0.521 & 0.142 & -- \\
\hline $6 / 20 / 2007$ & 1221 & 62.3 & 9.57 & 2 & 38.1 & 240 & 0.2 & 0 & 42 & 22 & 0.32 & $<0.02$ & $<0.01$ & 0.552 & 0.208 & 0.6 \\
\hline $6 / 12 / 2008$ & 1111 & 66.2 & 9.84 & 2 & 38.6 & 240 & 0.1 & 0 & 55 & 23 & 0.18 & 0.06 & 0.06 & 0.429 & 0.19 & -- \\
\hline $2 / 10 / 2009$ & 1126 & 71.8 & 10.7 & 3 & 41.8 & 230 & 0.2 & 0 & 58 & 24 & 0.24 & 0.17 & 0.17 & 0.491 & 0.222 & 0.64 \\
\hline $4 / 2 / 2009$ & 1216 & 74.2 & 11 & 3 & 44.5 & 230 & 0.2 & 0 & 56 & 24 & 0.29 & 0.18 & 0.18 & 0.705 & 0.19 & 0.56 \\
\hline $4 / 22 / 2009$ & 1201 & 71.5 & 10.6 & 2 & 40.9 & 230 & 0.2 & 0 & 58 & 24 & 0.23 & $<0.02$ & $<0.01$ & 0.675 & 0.18 & 0.62 \\
\hline $6 / 10 / 2009$ & 1121 & 71.3 & 10.5 & 2 & 42.2 & 230 & 0.1 & 0 & 57 & 23 & 0.22 & $<0.02$ & $<0.01$ & 0.521 & 0.18 & -- \\
\hline $6 / 10 / 2009$ & 1125 & 66.3 & 10 & 2.33 & 39.5 & -- & -- & -- & 59.2 & 27.7 & 0.223 & E.02 & E.02 & 0.586 & 0.18 & 0.8 \\
\hline $7 / 14 / 2009$ & 1151 & 73.2 & 10.8 & 3 & 41.1 & 230 & 0.2 & 0 & 58 & 24 & 0.22 & $<0.02$ & $<0.01$ & 0.46 & 0.28 & 0.62 \\
\hline 8/19/2009 & 1151 & 72.6 & 11.1 & 3 & 44.1 & 230 & 0.1 & 0 & 67 & 25 & 0.24 & $<0.02$ & $<0.01$ & 0.552 & 0.2 & 0.52 \\
\hline $11 / 17 / 2009$ & 1146 & 73.5 & 10.7 & 3 & 41 & 230 & 0.2 & 0 & 56 & 22 & 0.23 & 0.16 & 0.16 & 0.46 & 0.21 & 0.6 \\
\hline $3 / 9 / 2010$ & 1156 & 77.5 & 11.2 & 3 & 41.6 & 140 & 0.3 & 0 & 74 & 24 & 0.25 & 0.01 & 0.01 & 0.521 & 0.18 & 0.57 \\
\hline \multicolumn{17}{|c|}{ RB1 source water } \\
\hline $8 / 3 / 2007$ & 1106 & 23.6 & 4.12 & 12 & 47 & 110 & 0.1 & 0 & 21 & 86 & 0.05 & 0.79 & 0.76 & -- & 0.08 & 5.53 \\
\hline $8 / 3 / 2007$ & 1116 & 23.6 & 4.14 & 12 & 46.7 & 78 & 0.1 & 0 & 21 & 86 & 0.04 & 0.79 & 0.76 & -- & 0.105 & 5.49 \\
\hline $4 / 3 / 2009$ & 1216 & 49.5 & 9.87 & 11 & 39.1 & 44 & 0.1 & 0 & 62 & 100 & 0.54 & 2.68 & 2.58 & -- & $<0.03$ & 6.62 \\
\hline 4/14/2009 & 1141 & 43.4 & 9.5 & 9 & 77.9 & 120 & 0.2 & 0 & 65 & 110 & 0.15 & 2.29 & 2.19 & -- & 0.03 & 11.9 \\
\hline 4/17/2009 & 1111 & 67.9 & 13.8 & 10 & 86.5 & 140 & 0.2 & 0 & 94 & 130 & 0.03 & 1.3 & 1.26 & -- & $<0.03$ & 8.16 \\
\hline
\end{tabular}


Table 8. Summary of major ion data from water samples collected as part of the Equus Beds Experimental Passive Recharge Project at RB1, 2009-2010.-Continued [mg/L, milligrams per liter; --, not determined or not applicable; <, less than; $\mathrm{E}^{* *}$, estimated]

\begin{tabular}{|c|c|c|c|c|c|c|c|c|c|c|c|c|c|c|c|c|}
\hline $\begin{array}{c}\text { Date of } \\
\text { sample } \\
\text { collection } \\
\text { (month/day/ } \\
\text { year) }\end{array}$ & $\begin{array}{c}\text { Sample } \\
\text { start } \\
\text { time }\end{array}$ & $\begin{array}{l}\text { Calcium } \\
\text { (mg/L) }\end{array}$ & $\begin{array}{l}\text { Magnesium } \\
\quad(\mathrm{mg} / \mathrm{L})\end{array}$ & $\begin{array}{l}\text { Potassium } \\
\text { (mg/L) }\end{array}$ & $\begin{array}{l}\text { Sodium } \\
\text { (mg/L) }\end{array}$ & $\begin{array}{c}\text { Bicarbonate, } \\
\text { inflection- } \\
\text { point titration } \\
\text { method } \\
\text { (mg/L) }\end{array}$ & $\begin{array}{c}\text { Bromide } \\
\text { (mg/L) }\end{array}$ & $\begin{array}{c}\text { Carbonate, } \\
\text { inflection- } \\
\text { point titration } \\
\text { method } \\
\text { (mg/L) }\end{array}$ & $\begin{array}{c}\text { Chloride } \\
\text { (mg/L) }\end{array}$ & $\begin{array}{c}\text { Sulfate } \\
\text { (mg/L) }\end{array}$ & $\begin{array}{c}\text { Ammonia } \\
(\mathrm{mg} / \mathrm{L})\end{array}$ & $\begin{array}{c}\text { Nitrate } \\
\text { plus } \\
\text { nitrite } \\
\text { (mg/L) }\end{array}$ & $\begin{array}{l}\text { Nitrate } \\
\text { (mg/L) }\end{array}$ & $\begin{array}{c}\text { Ortho- } \\
\text { phosphate } \\
\text { (mg/L) }\end{array}$ & $\begin{array}{l}\text { Phosphorus } \\
\text { (mg/L) }\end{array}$ & $\begin{array}{c}\text { Organic } \\
\text { carbon } \\
\text { (mg/L) }\end{array}$ \\
\hline \multicolumn{17}{|c|}{ RB1-MN shallow } \\
\hline $8 / 30 / 2006$ & 1011 & 107.0 & 23.3 & 4.36 & 82.1 & 250 & 0.4 & 0 & 170 & 77.9 & 0.08 & $<0.02$ & $<0.01$ & 0.368 & 0.169 & 0.8 \\
\hline $11 / 29 / 2006$ & 1101 & 107.0 & 22.4 & 4.07 & 77.6 & 250 & 0.5 & 0 & 150 & 65.1 & -- & $<0.02$ & $<0.01$ & 0.307 & 0.257 & -- \\
\hline $2 / 23 / 2007$ & 1011 & 105.0 & 22.5 & 3.92 & 71.6 & 250 & 0.6 & 0 & 162 & 69.7 & -- & $<0.02$ & $<0.01$ & 0.368 & 0.275 & -- \\
\hline $6 / 4 / 2007$ & 1016 & 105.0 & 22.2 & 4 & 71 & 250 & 0.6 & 0 & 170 & 68 & -- & 0.19 & 0.19 & -- & 0.265 & -- \\
\hline $8 / 29 / 2007$ & 1021 & 97.6 & 20.3 & 4 & 70.5 & 240 & 0.4 & 0 & 150 & 78 & 0.08 & $<0.02$ & $<0.01$ & -- & 0.286 & 0.67 \\
\hline $8 / 29 / 2007$ & 1031 & 98.4 & 20.4 & 4 & 70.6 & 250 & 0.3 & 0 & 150 & 78 & 0.06 & $<0.02$ & $<0.01$ & -- & 0.319 & 0.64 \\
\hline $3 / 5 / 2008$ & 1026 & 111.0 & 22.8 & 4 & 69.8 & 240 & 0.7 & 0 & 160 & 74 & -- & $<0.02$ & $<0.01$ & -- & 0.267 & -- \\
\hline $3 / 5 / 2008$ & 1031 & 113.0 & 23.1 & 4 & 71.4 & 240 & 0.7 & 0 & 160 & 74 & -- & $<0.02$ & $<0.01$ & -- & 0.271 & -- \\
\hline $8 / 19 / 2008$ & 1011 & 107.0 & 22.2 & 4 & 70.9 & 250 & 0.7 & 0 & 150 & 84 & 0.06 & $<0.02$ & $<0.01$ & -- & 0.24 & 0.96 \\
\hline $2 / 9 / 2009$ & 1021 & 114.0 & 23.7 & 4 & 73.1 & 250 & 0.6 & 0 & 160 & 81 & 0.08 & 0.18 & 0.18 & -- & 0.269 & 0.65 \\
\hline 4/1/2009 & 1111 & 114.0 & 23.1 & 4 & 71 & 240 & 0.7 & 0 & 160 & 78 & 0.08 & 0.2 & 0.2 & -- & 0.22 & 0.66 \\
\hline $4 / 21 / 2009$ & 0956 & 115.0 & 23.3 & 4 & 68.7 & 240 & 0.7 & 0 & 160 & 79 & 0.07 & 0.22 & 0.22 & -- & 0.28 & 0.76 \\
\hline $6 / 25 / 2009$ & 1001 & 114.0 & 23.1 & 4 & 71.7 & 240 & 0.4 & 0 & 160 & 79 & 0.06 & 0.24 & 0.24 & -- & 0.24 & 1.03 \\
\hline $7 / 14 / 2009$ & 1026 & 107.0 & 21.9 & 4 & 70.2 & 250 & 0.3 & 0 & 150 & 84 & 0.06 & $<0.02$ & $<0.01$ & 0.184 & 0.38 & 0.82 \\
\hline $8 / 19 / 2009$ & 0956 & 107.0 & 22.3 & 4 & 71.6 & 250 & 0.3 & 0 & 150 & 89 & 0.09 & $<0.02$ & $<0.01$ & -- & 0.28 & 0.64 \\
\hline $11 / 18 / 2009$ & 1001 & 118.0 & 23.8 & 4 & 72.4 & 250 & 0.7 & 0 & 170 & 79 & 0.08 & 0.2 & 0.2 & -- & 0.25 & 0.72 \\
\hline $3 / 8 / 2010$ & 1006 & 112.0 & 22.5 & 4 & 72.1 & 260 & 0.6 & 0 & 160 & 84 & 0.07 & $<0.02$ & $<0.01$ & -- & 0.22 & 0.83 \\
\hline \multicolumn{17}{|c|}{ RB1-MN deep } \\
\hline $8 / 30 / 2006$ & 1156 & 65.8 & 11 & 3.06 & 49.2 & 250 & 0.1 & 0 & 47.8 & 28.8 & 0.22 & 0.23 & 0.23 & 0.521 & 0.243 & 1 \\
\hline $11 / 29 / 2006$ & 956 & 69.7 & 10.8 & 2.9 & 48.4 & 250 & 0.1 & 0 & 63.4 & 28.7 & -- & 0.1 & 0.1 & 0.429 & 0.261 & -- \\
\hline $2 / 23 / 2007$ & 1206 & 62.9 & 9.59 & 2.64 & 44.1 & 250 & 0.2 & 0 & 49.9 & 26.7 & -- & $<0.02$ & $<0.01$ & 0.491 & 0.287 & -- \\
\hline $6 / 4 / 2007$ & 1141 & 62.3 & 9.34 & 3 & 42.9 & 250 & 0.2 & 0 & 42 & 21 & -- & 0.16 & 0.16 & 0.245 & 0.273 & -- \\
\hline $6 / 4 / 2007$ & 1146 & 62.4 & 9.34 & 3 & 43 & 250 & 0.2 & 0 & 42 & 21 & -- & 0.16 & 0.16 & 0.276 & 0.273 & -- \\
\hline $8 / 29 / 2007$ & 1231 & 65.8 & 9.95 & 3 & 43.9 & 240 & 0.2 & 0 & 53 & 22 & 0.2 & $<0.02$ & $<0.01$ & 0.184 & 0.336 & 0.57 \\
\hline $3 / 5 / 2008$ & 1156 & 73.0 & 10.7 & 3 & 47.2 & 240 & 0.3 & 0 & 63 & 22 & -- & $<0.02$ & $<0.01$ & 0.153 & 0.266 & -- \\
\hline $8 / 19 / 2008$ & 1151 & 74.1 & 11.2 & 3 & 47.3 & 250 & 0.3 & 0 & 66 & 22 & 0.22 & $<0.02$ & $<0.01$ & 0.276 & 0.27 & 0.81 \\
\hline 2/9/2009 & 1151 & 75.3 & 11.2 & 3 & 48.6 & 240 & 0.3 & 0 & 64 & 22 & 0.26 & 0.17 & 0.17 & 0.184 & 0.247 & 0.67 \\
\hline 4/1/2009 & 1241 & 74.0 & 10.8 & 3 & 46.4 & 240 & 0.2 & 0 & 59 & 21 & 0.27 & 0.2 & 0.2 & 0.245 & 0.23 & 0.62 \\
\hline $4 / 21 / 2009$ & 1116 & 69.3 & 10.1 & 3 & 44.1 & 250 & 0.2 & 0 & 49 & 22 & 0.22 & $<0.02$ & $<0.01$ & 0.399 & 0.24 & 0.66 \\
\hline $6 / 25 / 2009$ & 1201 & 69.4 & 10.0 & 3 & 45.3 & 240 & 0.1 & 0 & 52 & 21 & 0.18 & 0.19 & 0.19 & 0.245 & 0.26 & 0.64 \\
\hline $6 / 25 / 2009$ & 1211 & 69.8 & 10.1 & 3 & 45.6 & 240 & 0.1 & 0 & 51 & 21 & 0.18 & 0.19 & 0.19 & 0.245 & 0.252 & 0.79 \\
\hline $7 / 14 / 2009$ & 1201 & 76.3 & 11.2 & 3 & 47 & 250 & 0.1 & 0 & 66 & 21 & 0.22 & $<0.02$ & $<0.01$ & 0.184 & 0.37 & 0.7 \\
\hline $8 / 19 / 2009$ & 1126 & 70.9 & 10.5 & 3 & 46.3 & 240 & 0.1 & 0 & 58 & 22 & 0.28 & $<0.02$ & $<0.01$ & 0.307 & 0.26 & 0.55 \\
\hline $11 / 18 / 2009$ & 1131 & 77.4 & 11.4 & 3 & 47.2 & 240 & 0.3 & 0 & 73 & 22 & 0.22 & 0.19 & 0.19 & 0.307 & 0.23 & 0.64 \\
\hline $3 / 8 / 2010$ & 1146 & 71.8 & 10.3 & 3 & 45.8 & 250 & 0.3 & 0 & 64 & 22 & 0.25 & 0.01 & 0.01 & 0.307 & 0.23 & 0.62 \\
\hline
\end{tabular}


$\left[\mathrm{mg} / \mathrm{L}\right.$, milligrams per liter; --, not determined or not applicable; <, less than; $\mathrm{E}^{* *}$, estimated]

\begin{tabular}{|c|c|c|c|c|c|c|c|c|c|c|c|c|c|c|c|c|}
\hline $\begin{array}{c}\text { Date of } \\
\text { sample } \\
\text { collection } \\
\text { (month/day/ } \\
\text { year) }\end{array}$ & $\begin{array}{c}\text { Sample } \\
\text { start } \\
\text { time }\end{array}$ & $\begin{array}{l}\text { Calcium } \\
\text { (mg/L) }\end{array}$ & $\begin{array}{l}\text { Magnesium } \\
\quad(\mathrm{mg} / \mathrm{L})\end{array}$ & $\begin{array}{l}\text { Potassium } \\
\text { (mg/L) }\end{array}$ & $\begin{array}{c}\text { Sodium } \\
\text { (mg/L) }\end{array}$ & $\begin{array}{c}\text { Bicarbonate, } \\
\text { inflection- } \\
\text { point titration } \\
\text { method } \\
(\mathrm{mg} / \mathrm{L})\end{array}$ & $\begin{array}{c}\text { Bromide } \\
\text { (mg/L) }\end{array}$ & $\begin{array}{c}\text { Carbonate, } \\
\text { inflection- } \\
\text { point titration } \\
\text { method } \\
\text { (mg/L) }\end{array}$ & $\begin{array}{c}\text { Chloride } \\
\text { (mg/L) }\end{array}$ & $\begin{array}{c}\text { Sulfate } \\
\text { (mg/L) }\end{array}$ & $\begin{array}{c}\text { Ammonia } \\
\text { (mg/L) }\end{array}$ & $\begin{array}{c}\text { Nitrate } \\
\text { plus } \\
\text { nitrite } \\
\text { (mg/L) }\end{array}$ & $\begin{array}{r}\text { Nitrate } \\
\text { (mg/L) }\end{array}$ & $\begin{array}{c}\text { Ortho- } \\
\text { phosphate } \\
\text { (mg/L) }\end{array}$ & $\begin{array}{l}\text { Phosphorus } \\
\text { (mg/L) }\end{array}$ & $\begin{array}{c}\text { Organic } \\
\text { carbon } \\
(\mathrm{mg} / \mathrm{L})\end{array}$ \\
\hline \multicolumn{17}{|c|}{ RB1-MS shallow } \\
\hline $8 / 30 / 2006$ & 1031 & 53.7 & 11.2 & 3.12 & 64 & 220 & $<0.03$ & 0 & 29.7 & 78 & 0.06 & 0.37 & 0.37 & 0.337 & 0.184 & 1 \\
\hline $11 / 29 / 2006$ & 1011 & 56.1 & 10.8 & 3.02 & 51.3 & 220 & 0.1 & 0 & 48.2 & 67.1 & -- & 0.16 & 0.16 & 0.399 & 0.224 & -- \\
\hline $2 / 23 / 2007$ & 1031 & 55 & 10.9 & 2.94 & 48 & 220 & 0.1 & 0 & 29.3 & 66.1 & -- & 0.19 & 0.19 & 0.368 & 0.231 & -- \\
\hline $6 / 4 / 2007$ & 1021 & 54.1 & 10.5 & 3 & 47.6 & 220 & 0.2 & 0 & 26 & 62 & -- & 0.32 & 0.32 & 0.061 & 0.215 & -- \\
\hline $8 / 29 / 2007$ & 1016 & 53.2 & 10.2 & 3 & 46.8 & 220 & 0.1 & 0 & 19 & 66 & 0.05 & $<0.02$ & $<0.01$ & 0.031 & 0.252 & 0.89 \\
\hline $3 / 4 / 2008$ & 1016 & 54.4 & 10.3 & 3 & 48.4 & 220 & 0.1 & 0 & 15 & 62 & 0.04 & $<0.02$ & $<0.01$ & 0.307 & 0.219 & -- \\
\hline $8 / 18 / 2008$ & 1031 & 53.7 & 10.4 & 3 & 49.4 & 220 & 0.1 & 0 & 14 & 64 & 0.05 & $<0.02$ & $<0.01$ & 0.123 & 0.22 & 0.95 \\
\hline 2/4/2009 & 1006 & 56 & 10.7 & 3 & 50.1 & 230 & 0.1 & 0 & 13 & 65 & $<0.03$ & 0.15 & 0.15 & 0.061 & 0.23 & 0.82 \\
\hline $3 / 24 / 2009$ & 1136 & 57.4 & 10.8 & 3 & 49 & 220 & 0.1 & 0 & 12 & 66 & 0.04 & 0.17 & 0.17 & 0.245 & 0.23 & 0.81 \\
\hline 4/6/2009 & 1011 & 57.3 & 11 & 3 & 51.2 & 220 & 0.1 & 0 & 13 & 66 & 0.05 & 0.14 & 0.14 & 0.337 & 0.25 & 0.86 \\
\hline 4/9/2009 & 1006 & 57.4 & 11 & 3 & 50.3 & 230 & 0.1 & 0 & 14 & 68 & 0.04 & $<0.02$ & $<0.01$ & 0.153 & 0.2 & 0.87 \\
\hline $4 / 16 / 2009$ & 1016 & 56 & 10.8 & 3 & 49.6 & 220 & 0.1 & 0 & 14 & 68 & $<0.03$ & $<0.02$ & $<0.01$ & 0.153 & 0.25 & 0.89 \\
\hline $4 / 20 / 2009$ & 1006 & 57.3 & 11.3 & 3 & 52.6 & 220 & 0.1 & 0 & 14 & 67 & 0.04 & $<0.02$ & $<0.01$ & 0.245 & 0.2 & 0.89 \\
\hline $5 / 6 / 2009$ & 1026 & 55.9 & 10.8 & 3 & 49 & 220 & 0.1 & 0 & 14 & 64 & 0.032 & 0.04 & 0.04 & 0.061 & 0.25 & 0.87 \\
\hline $5 / 20 / 2009$ & 1006 & 56.2 & 10.8 & 3 & 50.3 & 220 & 0.1 & 0 & 15 & 64 & 0.03 & 0.02 & 0.02 & 0.061 & 0.252 & 0.95 \\
\hline $6 / 25 / 2009$ & 1001 & 55.1 & 10.5 & 3 & 49.4 & 220 & 0.2 & 0 & 16 & 66 & 0.04 & 0.02 & 0.02 & 0.123 & 0.215 & 0.85 \\
\hline 7/8/2009 & 1021 & 56.8 & 10.7 & 3 & 49 & 220 & 0.1 & 0 & 15 & 69 & 0.05 & $<0.02$ & $<0.01$ & -- & 0.22 & 0.89 \\
\hline $7 / 13 / 2009$ & 1016 & 57.5 & 11 & 3 & 49.5 & 220 & 0.1 & 0 & 14 & 71 & 0.04 & $<0.02$ & $<0.01$ & -- & 0.35 & 0.85 \\
\hline $7 / 20 / 2009$ & 1016 & 57.5 & 11.1 & 3 & 49.7 & 230 & 0.4 & 0 & 13 & 73 & 0.03 & $<0.02$ & $<0.01$ & 0.061 & 0.18 & 0.91 \\
\hline $8 / 18 / 2009$ & 1011 & 59.4 & 11.3 & 3 & 51.1 & 220 & 0.1 & 0 & 14 & 75 & 0.06 & $<0.02$ & $<0.01$ & 0.184 & 0.24 & 0.72 \\
\hline $11 / 18 / 2009$ & 1006 & 55.3 & 10.5 & 3 & 48.2 & 210 & 0.1 & 0 & 15 & 68 & 0.09 & $<0.02$ & $<0.01$ & 0.184 & 0.24 & 0.87 \\
\hline $3 / 1 / 2010$ & 1131 & 53.3 & 10.1 & 3 & 46.6 & 210 & 0.1 & 0 & 20 & 69 & 0.06 & 0.01 & 0.01 & 0.215 & 0.19 & 0.84 \\
\hline
\end{tabular}


Table 8. Summary of major ion data from water samples collected as part of the Equus Beds Experimental Passive Recharge Project at RB1, 2009-2010.—Continued [mg/L, milligrams per liter; --, not determined or not applicable; <, less than; $\mathrm{E}^{* *}$, estimated]

\begin{tabular}{|c|c|c|c|c|c|c|c|c|c|c|c|c|c|c|c|c|}
\hline $\begin{array}{c}\text { Date of } \\
\text { sample } \\
\text { collection } \\
\text { (month/day/ } \\
\text { year) } \\
\end{array}$ & $\begin{array}{c}\text { Sample } \\
\text { start } \\
\text { time }\end{array}$ & $\begin{array}{l}\text { Calcium } \\
\text { (mg/L) }\end{array}$ & $\begin{array}{l}\text { Magnesium } \\
\quad(\mathrm{mg} / \mathrm{L})\end{array}$ & $\begin{array}{l}\text { Potassium } \\
\text { (mg/L) }\end{array}$ & $\begin{array}{c}\text { Sodium } \\
\text { (mg/L) }\end{array}$ & $\begin{array}{c}\text { Bicarbonate, } \\
\text { inflection- } \\
\text { point titration } \\
\text { method } \\
\text { (mg/L) }\end{array}$ & $\begin{array}{c}\text { Bromide } \\
\text { (mg/L) }\end{array}$ & $\begin{array}{c}\text { Carbonate, } \\
\text { inflection- } \\
\text { point titration } \\
\text { method } \\
(\mathrm{mg} / \mathrm{L})\end{array}$ & $\begin{array}{c}\text { Chloride } \\
\text { (mg/L) }\end{array}$ & $\begin{array}{l}\text { Sulfate } \\
\text { (mg/L) }\end{array}$ & $\begin{array}{c}\text { Ammonia } \\
\text { (mg/L) }\end{array}$ & $\begin{array}{c}\text { Nitrate } \\
\text { plus } \\
\text { nitrite } \\
\text { (mg/L) }\end{array}$ & $\begin{array}{l}\text { Nitrate } \\
\text { (mg/L) }\end{array}$ & $\begin{array}{c}\text { Ortho- } \\
\text { phosphate } \\
\text { (mg/L) }\end{array}$ & $\begin{array}{c}\text { Phosphorus } \\
\text { (mg/L) }\end{array}$ & $\begin{array}{c}\text { Organic } \\
\text { carbon } \\
(\mathrm{mg} / \mathrm{L})\end{array}$ \\
\hline \multicolumn{17}{|c|}{ RB1-MS deep } \\
\hline $8 / 30 / 2006$ & 1246 & 64.9 & 10.2 & 2.75 & 44.9 & 240 & 0.1 & 0 & 45.1 & 27.6 & 0.24 & 0.05 & 0.05 & 0.613 & 0.214 & 0.8 \\
\hline $12 / 4 / 2006$ & 1001 & 64.2 & 9.41 & 2.52 & 41.8 & 240 & 0.1 & 0 & 44.7 & 26.6 & -- & 0.07 & 0.07 & 0.583 & 0.238 & -- \\
\hline $2 / 23 / 2007$ & 1146 & 62.2 & 9.43 & 2.43 & 40.1 & 240 & 0.3 & 0 & 43.9 & 31.8 & -- & 0.02 & 0.02 & 0.429 & 0.235 & -- \\
\hline $6 / 4 / 2007$ & 1151 & 62 & 9.28 & 2 & 39.2 & 240 & 0.2 & 0 & 41 & 22 & -- & $<0.02$ & $<0.01$ & 0.491 & 0.231 & -- \\
\hline $8 / 29 / 2007$ & 1206 & 61.4 & 9.01 & 2 & 38.6 & 230 & 0.2 & 0 & 40 & 24 & 0.22 & $<0.02$ & $<0.01$ & 0.429 & 0.258 & 0.68 \\
\hline $3 / 4 / 2008$ & 1201 & 64.2 & 9.27 & 2 & 40.2 & 230 & 0.2 & 0 & 37 & 23 & 0.2 & $<0.02$ & $<0.01$ & 0.491 & 0.212 & -- \\
\hline $8 / 18 / 2008$ & 1231 & 67.3 & 9.83 & 3 & 42.1 & 240 & 0.2 & 0 & 44 & 24 & 0.27 & $<0.02$ & $<0.01$ & 0.521 & 0.21 & 0.84 \\
\hline 2/4/2009 & 1141 & 59.9 & 8.66 & 2 & 39 & 230 & 0.1 & 0 & 26 & 25 & 0.2 & 0.17 & 0.17 & 0.491 & 0.24 & 0.66 \\
\hline $3 / 24 / 2009$ & 1306 & 64.6 & 9.2 & 2 & 39.2 & 230 & 0.1 & 0 & 35 & 23 & 0.24 & 0.17 & 0.17 & 0.583 & 0.23 & 0.6 \\
\hline 4/6/2009 & 1141 & 64.4 & 9.4 & 3 & 41.5 & 230 & 0.1 & 0 & 30 & 24 & 0.28 & 0.17 & 0.17 & 0.613 & 0.21 & 0.68 \\
\hline 4/9/2009 & 1136 & 64.8 & 9.46 & 2 & 41.8 & 240 & 0.1 & 0 & 30 & 24 & 0.21 & $<0.02$ & $<0.01$ & 0.644 & 0.2 & 0.66 \\
\hline 4/16/2009 & 1141 & 63 & 9.24 & 2 & 40.2 & 230 & 0.1 & 0 & 31 & 24 & 0.16 & $<0.02$ & $<0.01$ & 0.675 & 0.21 & 0.74 \\
\hline $4 / 20 / 2009$ & 1136 & 65.1 & 9.66 & 3 & 42 & 230 & 0.1 & 0 & 33 & 24 & 0.23 & $<0.02$ & $<0.01$ & 0.613 & 0.21 & 0.69 \\
\hline $5 / 6 / 2009$ & 1151 & 64 & 9.35 & 2 & 39.4 & 230 & 0.1 & 0 & 31 & 24 & 0.262 & $<0.02$ & $<0.01$ & 0.46 & 0.22 & 0.62 \\
\hline $5 / 20 / 2009$ & 1141 & 63.2 & 9.16 & 2 & 39.8 & 230 & 0.1 & 0 & 29 & 24 & 0.2 & $<0.02$ & $<0.01$ & 0.491 & 0.221 & 0.73 \\
\hline $6 / 25 / 2009$ & 1146 & 63.2 & 9.14 & 2 & 40 & 230 & 0.1 & 0 & 31 & 24 & 0.18 & $<0.02$ & $<0.01$ & 0.46 & 0.237 & 0.65 \\
\hline 7/8/2009 & 1206 & 62.7 & 8.95 & 2 & 38.8 & 240 & 0.1 & 0 & 30 & 25 & 0.22 & $<0.02$ & $<0.01$ & 0.46 & 0.21 & 0.67 \\
\hline 7/13/2009 & 1156 & 62.3 & 8.98 & 2 & 38.9 & 230 & 0.1 & 0 & 30 & 25 & 0.22 & $<0.02$ & $<0.01$ & 0.491 & 0.24 & 0.68 \\
\hline 7/20/2009 & 1241 & 62.8 & 9.08 & 2 & 39.4 & 240 & 0.1 & 0 & 29 & 25 & 0.22 & $<0.02$ & $<0.01$ & 0.613 & 0.24 & 0.63 \\
\hline 8/18/2009 & 1146 & 59.5 & 8.7 & 2 & 38.3 & 230 & 0.1 & 0 & 25 & 26 & 0.24 & $<0.02$ & $<0.01$ & 0.552 & 0.24 & 0.55 \\
\hline 11/18/2009 & 1136 & 58.6 & 8.36 & 2 & 37.2 & 230 & 0.1 & 0 & 22 & 26 & 0.21 & 0.15 & 0.15 & 0.583 & 0.24 & 0.75 \\
\hline 3/1/2010 & 1256 & 57 & 8.09 & 2 & 36.7 & 230 & 0.1 & 0 & 24 & 26 & 0.26 & $<0.02$ & $<0.01$ & 0.552 & 0.21 & 0.6 \\
\hline
\end{tabular}


[mg/L, milligrams per liter; --, not determined or not applicable; <, less than; $\mathrm{E}^{* *}$, estimated]

\begin{tabular}{|c|c|c|c|c|c|c|c|c|c|c|c|c|c|c|c|c|}
\hline $\begin{array}{c}\text { Date of } \\
\text { sample } \\
\text { collection } \\
\text { (month/day/ } \\
\text { year) }\end{array}$ & $\begin{array}{c}\text { Sample } \\
\text { start } \\
\text { time }\end{array}$ & $\begin{array}{c}\text { Calcium } \\
\text { (mg/L) }\end{array}$ & $\begin{array}{l}\text { Magnesium } \\
\quad(\mathrm{mg} / \mathrm{L})\end{array}$ & $\begin{array}{l}\text { Potassium } \\
\text { (mg/L) }\end{array}$ & $\begin{array}{l}\text { Sodium } \\
\text { (mg/L) }\end{array}$ & $\begin{array}{c}\text { Bicarbonate, } \\
\text { inflection- } \\
\text { point titration } \\
\text { method } \\
\text { (mg/L) }\end{array}$ & $\begin{array}{c}\text { Bromide } \\
\text { (mg/L) }\end{array}$ & $\begin{array}{c}\text { Carbonate, } \\
\text { inflection- } \\
\text { point titration } \\
\text { method } \\
\text { (mg/L) }\end{array}$ & $\begin{array}{c}\text { Chloride } \\
\text { (mg/L) }\end{array}$ & $\begin{array}{c}\text { Sulfate } \\
\text { (mg/L) }\end{array}$ & $\begin{array}{c}\text { Ammonia } \\
\text { (mg/L) }\end{array}$ & $\begin{array}{c}\text { Nitrate } \\
\text { plus } \\
\text { nitrite } \\
\text { (mg/L) }\end{array}$ & $\begin{array}{l}\text { Nitrate } \\
\text { (mg/L) }\end{array}$ & $\begin{array}{c}\text { Ortho- } \\
\text { phosphate } \\
\text { (mg/L) }\end{array}$ & $\begin{array}{l}\text { Phosphorus } \\
\text { (mg/L) }\end{array}$ & $\begin{array}{c}\text { Organic } \\
\text { carbon } \\
(\mathrm{mg} / \mathrm{L})\end{array}$ \\
\hline \multicolumn{17}{|c|}{ RB1-PMS shallow } \\
\hline $1 / 22 / 2009$ & 1416 & 56.5 & 11.3 & 3 & 48.1 & 180 & 0.2 & 0 & 39 & 67 & $<0.03$ & 1.8 & 1.79 & 0.307 & 0.09 & 0.79 \\
\hline $2 / 2 / 2009$ & 1036 & 56.2 & 11.4 & 3 & 48.3 & 180 & 0.2 & 0 & 42 & 67 & $<0.03$ & 1.91 & 1.91 & 0.184 & 0.07 & 0.73 \\
\hline $3 / 26 / 2009$ & 1116 & 46.7 & 9.3 & 3 & 39.4 & 170 & 0.1 & 0 & 21 & 41 & $<0.03$ & 1.42 & 1.4 & 0.307 & 0.11 & 0.64 \\
\hline 4/4/2009 & 1006 & 48.7 & 9.94 & 3 & 42.7 & 150 & 0.1 & 0 & 25 & 54 & $<0.03$ & 1.82 & 1.78 & 0.307 & 0.1 & 0.94 \\
\hline $4 / 8 / 2009$ & 1006 & 56.5 & 11.3 & 3 & 59.1 & 130 & 0.2 & 0 & 57 & 92 & $<0.03$ & 2.23 & 2.2 & 0.307 & 0.09 & 4.44 \\
\hline $4 / 15 / 2009$ & 1046 & 51 & 9.76 & 4 & 51.7 & 130 & 0.1 & 0 & 48 & 74 & $<0.03$ & 2.08 & 2.08 & 0.276 & 0.09 & 2.82 \\
\hline $4 / 18 / 2009$ & 1011 & 56.1 & 10.6 & 6 & 69.7 & 130 & 0.2 & 0 & 66 & 98 & $<0.03$ & 1.9 & 1.9 & 0.337 & 0.12 & 4.67 \\
\hline $5 / 6 / 2009$ & 1016 & 42.2 & 8.4 & 4 & 43 & 120 & 0.1 & 0 & 34 & 62 & $<0.03$ & 1.59 & 1.59 & 0.46 & 0.16 & 2.27 \\
\hline $5 / 20 / 2009$ & 1021 & 51.6 & 10.2 & 5 & 47.6 & 150 & 0.2 & 0 & 39 & 64 & $<0.03$ & 1.47 & 1.47 & 0.337 & 0.127 & 1.36 \\
\hline 7/8/2009 & 1126 & 55.2 & 10.9 & 3 & 44.6 & 170 & 0.3 & 0 & 81 & 58 & $<0.03$ & 0.98 & 0.96 & 0.644 & 0.1 & 0.84 \\
\hline $7 / 13 / 2009$ & 1016 & 68.1 & 13.4 & 4 & 54.4 & 190 & 0.4 & 0 & 78 & 50 & 0.08 & 0.73 & 0.71 & 0.429 & 0.13 & 0.91 \\
\hline $7 / 20 / 2009$ & 1026 & 73.4 & 14.5 & 4 & 57.7 & 200 & 0.4 & 0 & 98 & 46 & $<0.03$ & 0.74 & 0.73 & 0.429 & 0.16 & 0.82 \\
\hline $8 / 18 / 2009$ & 1011 & 52.7 & 10.9 & 3 & 43.9 & 150 & 0.2 & 0 & 40 & 68 & $<0.03$ & 0.82 & 0.81 & 0.215 & 0.09 & 0.83 \\
\hline $11 / 17 / 2009$ & 0951 & 58.8 & 11.8 & 3 & 46.3 & 160 & 0.2 & 0 & 44 & 78 & $<0.03$ & 1.2 & 1.16 & 0.245 & 0.07 & 0.99 \\
\hline $3 / 2 / 2010$ & 1046 & 57.2 & 11.5 & 3 & 45.6 & 160 & 0.2 & 0 & 46 & 83 & 0.04 & 1.18 & 1.14 & 0.245 & 0.08 & 0.77 \\
\hline $3 / 2 / 2010$ & 1051 & 57.9 & 11.5 & 3 & 45.6 & 160 & 0.2 & 0 & 46 & 83 & $<0.03$ & 1.17 & 1.13 & 0.245 & 0.08 & 0.76 \\
\hline \multicolumn{17}{|c|}{ RB1-PMS deep } \\
\hline $1 / 22 / 2009$ & 1301 & 68.1 & 13.3 & 3 & 56.4 & 200 & 0.4 & 0 & 75 & 58 & 0.05 & 1.13 & 1.09 & -- & 0.15 & 0.85 \\
\hline $2 / 2 / 2009$ & 1206 & 56.1 & 11.5 & 3 & 51.1 & 180 & 0.2 & 0 & 38 & 72 & $<0.03$ & 1.77 & 1.77 & 0.583 & 0.2 & 0.83 \\
\hline $3 / 26 / 2009$ & 1241 & 47.2 & 9.6 & 3 & 41 & 180 & 0.1 & 0 & 17 & 42 & 0.03 & 1.39 & 1.38 & 0.613 & 0.21 & 0.82 \\
\hline 4/4/2009 & 1131 & 50.4 & 10.3 & 3 & 46.1 & 160 & 0.1 & 0 & 25 & 59 & 0.04 & 1.95 & 1.9 & 0.644 & 0.21 & 1.19 \\
\hline $4 / 8 / 2009$ & 1131 & 58.4 & 11.5 & 3 & 66.1 & 140 & 0.2 & 0 & 59 & 94 & 0.04 & 2.51 & 2.47 & 0.644 & 0.2 & 3.95 \\
\hline $4 / 15 / 2009$ & 1216 & 53.5 & 10 & 5 & 57.6 & 150 & 0.2 & 0 & 52 & 75 & $<0.03$ & 2.09 & 2.09 & 0.675 & 0.23 & 2.93 \\
\hline $4 / 18 / 2009$ & 1146 & 56.6 & 10.9 & 6 & 73.1 & 140 & 0.2 & 0 & 64 & 99 & $<0.03$ & 2.15 & 2.15 & 0.644 & 0.23 & 4.7 \\
\hline $5 / 6 / 2009$ & 1141 & 41.9 & 8.72 & 5 & 43.4 & 120 & 0.1 & 0 & 30 & 65 & $<0.03$ & 1.72 & 1.72 & 0.675 & 0.23 & 2.19 \\
\hline $5 / 20 / 2009$ & 1151 & 46.5 & 9.48 & 5 & 45.8 & 150 & 0.1 & 0 & 28 & 58 & 0.03 & 1.86 & 1.86 & 0.675 & 0.212 & 1.66 \\
\hline 7/8/2009 & 1006 & 73.4 & 14.4 & 5 & 57 & 200 & 0.2 & 0 & 40 & 59 & $<0.03$ & 1.5 & 1.48 & 0.307 & 0.19 & 1.06 \\
\hline $7 / 13 / 2009$ & 1141 & 83.2 & 16 & 5 & 63 & 220 & 0.2 & 0 & 110 & 47 & 0.04 & 0.93 & 0.92 & 0.705 & 0.18 & 1.06 \\
\hline $7 / 20 / 2009$ & 1201 & 95 & 18.1 & 6 & 70 & 230 & 0.3 & 0 & 150 & 41 & $<0.03$ & 0.8 & 0.8 & 0.491 & 0.2 & 0.95 \\
\hline $8 / 18 / 2009$ & 1146 & 61.1 & 13 & 4 & 50.8 & 180 & 0.2 & 0 & 50 & 77 & $<0.03$ & 1.02 & 1.01 & 0.613 & 0.2 & 1 \\
\hline $11 / 17 / 2009$ & 1121 & 56.2 & 11.7 & 3 & 48.4 & 160 & 0.2 & 0 & 44 & 79 & $<0.03$ & 1.21 & 1.17 & 0.613 & 0.18 & 1.09 \\
\hline $3 / 2 / 2010$ & 1256 & 58.8 & 11.9 & 3 & 49 & 170 & 0.2 & 0 & 47 & 88 & $<0.03$ & 0.92 & 0.88 & 0.521 & 0.15 & 0.95 \\
\hline $3 / 22 / 2010$ & 1026 & 60 & 12.4 & 3 & 51.2 & 170 & 0.2 & 0 & 48 & 90 & $<0.03$ & 0.89 & 0.86 & 0.521 & 0.17 & 0.97 \\
\hline
\end{tabular}


Table 8. Summary of major ion data from water samples collected as part of the Equus Beds Experimental Passive Recharge Project at RB1, 2009-2010.—Continued $\left[\mathrm{mg} / \mathrm{L}\right.$, milligrams per liter; --, not determined or not applicable; $<$, less than; $\mathrm{E}^{* *}$, estimated]

\begin{tabular}{|c|c|c|c|c|c|c|c|c|c|c|c|c|c|c|c|c|}
\hline $\begin{array}{c}\text { Date of } \\
\text { sample } \\
\text { collection } \\
\text { (month/day/ } \\
\text { year) }\end{array}$ & $\begin{array}{c}\text { Sample } \\
\text { start } \\
\text { time }\end{array}$ & $\begin{array}{l}\text { Calcium } \\
\text { (mg/L) }\end{array}$ & $\begin{array}{l}\text { Magnesium } \\
\quad(\mathrm{mg} / \mathrm{L})\end{array}$ & $\begin{array}{l}\text { Potassium } \\
\text { (mg/L) }\end{array}$ & $\begin{array}{c}\text { Sodium } \\
\text { (mg/L) }\end{array}$ & $\begin{array}{l}\text { Bicarbonate, } \\
\text { inflection- } \\
\text { point titration } \\
\text { method } \\
\text { (mg/L) }\end{array}$ & $\begin{array}{c}\text { Bromide } \\
\text { (mg/L) }\end{array}$ & $\begin{array}{c}\text { Carbonate, } \\
\text { inflection- } \\
\text { point titration } \\
\text { method } \\
\text { (mg/L) }\end{array}$ & $\begin{array}{c}\text { Chloride } \\
\text { (mg/L) }\end{array}$ & $\begin{array}{l}\text { Sulfate } \\
\text { (mg/L) }\end{array}$ & $\begin{array}{c}\text { Ammonia } \\
\text { (mg/L) }\end{array}$ & $\begin{array}{l}\text { Nitrate } \\
\text { plus } \\
\text { nitrite } \\
\text { (mg/L) }\end{array}$ & $\begin{array}{l}\text { Nitrate } \\
\text { (mg/L) }\end{array}$ & $\begin{array}{c}\text { Ortho- } \\
\text { phosphate } \\
\text { (mg/L) }\end{array}$ & $\begin{array}{l}\text { Phosphorus } \\
\text { (mg/L) }\end{array}$ & $\begin{array}{c}\text { Organic } \\
\text { carbon } \\
(\mathrm{mg} / \mathrm{L})\end{array}$ \\
\hline \multicolumn{17}{|c|}{ RB1-P shallow } \\
\hline $1 / 21 / 2009$ & 1501 & 56 & 11.7 & 3 & 52.6 & 170 & 0.2 & 0 & 40 & 84 & 0.05 & 1.36 & 1.36 & 0.307 & 0.08 & 0.96 \\
\hline 2/3/2009 & 1016 & 62.9 & 13.6 & 3 & 70.6 & 210 & 0.2 & 0 & 38 & 110 & $<0.03$ & 2.36 & 2.36 & 0.307 & 0.11 & 1.36 \\
\hline $2 / 3 / 2009$ & 1021 & 62.3 & 13.3 & 3 & 68.8 & 210 & 0.1 & 0 & 38 & 110 & $<0.03$ & 2.37 & 2.37 & 0.307 & 0.12 & 1.32 \\
\hline $3 / 25 / 2009$ & 1036 & 58.1 & 10.7 & 3 & 52.7 & 180 & 0.1 & 0 & 19 & 90 & $<0.03$ & 1.5 & 1.5 & 0.429 & 0.11 & 1.04 \\
\hline 4/4/2009 & 1311 & 61.6 & 8.23 & 5 & 58.1 & 82 & 0.1 & 0 & 64 & 110 & 0.2 & 2.75 & 2.66 & 0.245 & 0.06 & 5.59 \\
\hline $4 / 4 / 2009$ & 1316 & 60.3 & 8.02 & 5 & 56.6 & 79 & 0.1 & 0 & 64 & 110 & 0.2 & 2.78 & 2.7 & 0.245 & 0.06 & 5.72 \\
\hline 4/7/2009 & 1156 & 57.9 & 11.1 & 11 & 83.4 & 120 & 0.2 & 0 & 80 & 120 & 0.17 & 2.73 & 2.66 & 0.153 & 0.06 & 7.29 \\
\hline 4/15/2009 & 1041 & 54.4 & 10.6 & 9 & 80.5 & 130 & 0.2 & 0 & 80 & 110 & 0.04 & 2.32 & 2.32 & 0.184 & 0.06 & 7.68 \\
\hline $4 / 18 / 2009$ & 1011 & 56.5 & 11.7 & 10 & 85.9 & 120 & 0.2 & 0 & 84 & 120 & $<0.03$ & 1.77 & 1.77 & 0.153 & 0.06 & 7.2 \\
\hline $5 / 4 / 2009$ & 1226 & 32.3 & 6.51 & 7 & 38.4 & 73 & 0.1 & 0 & 24 & 86 & $<0.03$ & 0.6 & 0.6 & 0.123 & 0.04 & 3.18 \\
\hline $5 / 19 / 2009$ & 1146 & 54.2 & 11 & 7 & 61.4 & 190 & 0.1 & 0 & 34 & 80 & 0.03 & 1.99 & 1.99 & 0.276 & 0.111 & 2.27 \\
\hline $8 / 17 / 2009$ & 1051 & 68.3 & 13.9 & 4 & 55.6 & 160 & 0.2 & 0 & 54 & 110 & $<0.03$ & 0.19 & 0.19 & 0.215 & 0.07 & 1.01 \\
\hline $11 / 16 / 2009$ & 1016 & 62.2 & 12.9 & 3 & 52 & 160 & 0.2 & 0 & 47 & 100 & $<0.03$ & 0.52 & 0.49 & 0.215 & 0.06 & 1.11 \\
\hline $3 / 3 / 2010$ & 1021 & 59.4 & 12 & 3 & 50.9 & 160 & 0.2 & 0 & 43 & 110 & 0.05 & 0.36 & 0.32 & 0.307 & 0.1 & 1.19 \\
\hline \multicolumn{17}{|c|}{ RB1-P deep } \\
\hline $2 / 3 / 2009$ & 1151 & 62.9 & 13.5 & 3 & 69.1 & 220 & 0.1 & 0 & 38 & 120 & $<0.03$ & 2.46 & 2.46 & 0.399 & 0.11 & 1.33 \\
\hline $3 / 25 / 2009$ & 1206 & 57.6 & 10.6 & 3 & 51.9 & 180 & 0.1 & 0 & 19 & 89 & $<0.03$ & 1.52 & 1.52 & 0.429 & 0.11 & 1.04 \\
\hline $4 / 4 / 2009$ & 1441 & 61.3 & 8.2 & 5 & 58 & 83 & 0.1 & 0 & 64 & 110 & 0.17 & 2.76 & 2.68 & 0.245 & 0.06 & 5.71 \\
\hline 4/7/2009 & 1321 & 56.9 & 10.9 & 11 & 81.9 & 120 & 0.2 & 0 & 80 & 120 & 0.2 & 2.72 & 2.65 & 0.153 & 0.07 & 7.2 \\
\hline $4 / 15 / 2009$ & 1211 & 55.1 & 10.7 & 9 & 80.9 & 140 & 0.2 & 0 & 80 & 110 & 0.03 & 2.31 & 2.31 & 0.184 & 0.06 & 7.51 \\
\hline $4 / 18 / 2009$ & 1131 & 57.1 & 11.7 & 10 & 85.8 & 120 & 0.2 & 0 & 84 & 120 & $<0.03$ & 1.78 & 1.78 & 0.153 & 0.06 & 7.43 \\
\hline $5 / 4 / 2009$ & 1336 & 32.4 & 6.56 & 7 & 38.8 & 68 & 0.1 & 0 & 24 & 86 & $<0.03$ & 0.6 & 0.6 & 0.092 & 0.04 & 3.2 \\
\hline $5 / 19 / 2009$ & 1301 & 54.5 & 11.1 & 7 & 61.3 & 190 & 0.1 & 0 & 33 & 79 & $<0.03$ & 2.04 & 2.04 & 0.276 & 0.102 & 2.24 \\
\hline 7/9/2009 & 1056 & 67.5 & 12.1 & 5 & 56.8 & 200 & 0.3 & 0 & 73 & 62 & 0.05 & 0.4 & 0.39 & 0.184 & 0.06 & 1.41 \\
\hline 7/13/2009 & 1236 & 71.8 & 12.9 & 4 & 56.6 & 200 & 0.3 & 0 & 74 & 61 & 0.12 & 0.16 & 0.16 & 0.184 & 0.07 & 1.13 \\
\hline $7 / 20 / 2009$ & 1001 & 75.7 & 13.9 & 4 & 58 & 200 & 0.3 & 0 & 81 & 63 & 0.09 & 0.12 & 0.12 & 0.153 & 0.07 & 1.07 \\
\hline $8 / 12 / 2009$ & 1021 & 81.70 & 15.1 & 4 & 60.6 & 210 & 0.2 & 0 & 95 & 69 & 0.078 & 0.15 & 0.15 & 0.245 & 0.07 & 0.84 \\
\hline 8/17/2009 & 1211 & 69.30 & 14.1 & 4 & 55.7 & 160 & 0.2 & 0 & 56 & 110 & 0.04 & 0.16 & 0.16 & 0.215 & 0.08 & 0.99 \\
\hline $11 / 16 / 2009$ & 1126 & 67.70 & 13.8 & 3 & 54 & 160 & 0.2 & 0 & 53 & 110 & 0.05 & 0.39 & 0.36 & 0.215 & 0.06 & 1 \\
\hline $3 / 3 / 2010$ & 1136 & 65.00 & 13 & 3 & 52.4 & 160 & 0.2 & 0 & 50 & 110 & $<0.03$ & 0.28 & 0.22 & 0.215 & 0.08 & 0.97 \\
\hline
\end{tabular}


[mg/L, milligrams per liter; --, not determined or not applicable; <, less than; $\mathrm{E}^{* *}$, estimated]

\begin{tabular}{|c|c|c|c|c|c|c|c|c|c|c|c|c|c|c|c|c|}
\hline $\begin{array}{c}\text { Date of } \\
\text { sample } \\
\text { collection } \\
\text { (month/day/ } \\
\text { year) }\end{array}$ & $\begin{array}{c}\text { Sample } \\
\text { start } \\
\text { time }\end{array}$ & $\begin{array}{c}\text { Calcium } \\
\text { (mg/L) }\end{array}$ & $\begin{array}{l}\text { Magnesium } \\
\quad(\mathrm{mg} / \mathrm{L})\end{array}$ & $\begin{array}{l}\text { Potassium } \\
\text { (mg/L) }\end{array}$ & $\begin{array}{c}\text { Sodium } \\
\text { (mg/L) }\end{array}$ & $\begin{array}{l}\text { Bicarbonate, } \\
\text { inflection- } \\
\text { point titration } \\
\text { method } \\
\text { (mg/L) }\end{array}$ & $\begin{array}{c}\text { Bromide } \\
\text { (mg/L) }\end{array}$ & $\begin{array}{c}\text { Carbonate, } \\
\text { inflection- } \\
\text { point titration } \\
\text { method (mg/L) }\end{array}$ & $\begin{array}{c}\text { Chloride } \\
\text { (mg/L) }\end{array}$ & $\begin{array}{c}\text { Sulfate } \\
\text { (mg/L) }\end{array}$ & $\begin{array}{c}\text { Ammonia } \\
\text { (mg/L) }\end{array}$ & $\begin{array}{l}\text { Nitrate } \\
\text { plus } \\
\text { nitrite } \\
\text { (mg/L) }\end{array}$ & $\begin{array}{c}\text { Nitrate } \\
\text { (mg/L) }\end{array}$ & $\begin{array}{c}\text { Ortho- } \\
\text { phosphate } \\
\text { (mg/L) }\end{array}$ & $\begin{array}{c}\text { Phosphorus } \\
\text { (mg/L) }\end{array}$ & $\begin{array}{c}\text { Organic } \\
\text { carbon } \\
(\mathrm{mg} / \mathrm{L})\end{array}$ \\
\hline \multicolumn{17}{|c|}{ RB1-P TR } \\
\hline $3 / 26 / 2009$ & 1021 & 57.40 & 11.00 & 3.00 & 54.40 & 180 & 0.10 & 0 & 20.0 & 90.0 & $<0.030$ & 1.70 & 1.69 & 0.491 & 0.130 & 1.15 \\
\hline $4 / 3 / 2009$ & 1351 & 59.50 & 8.26 & 3.00 & 36.10 & 85 & 0.10 & 0 & 43.0 & 89.0 & 0.090 & 2.66 & 2.60 & 0.276 & 0.080 & 3.78 \\
\hline $4 / 7 / 2009$ & 1001 & 57.40 & 10.90 & 11.00 & 82.40 & 120 & 0.20 & 0 & 80.0 & 120.0 & 0.260 & 2.73 & 2.66 & 0.153 & 0.070 & 7.17 \\
\hline 4/7/2009 & 1006 & 58.30 & 11.10 & 11.00 & 83.60 & 120 & 0.20 & 0 & 80.0 & 120.0 & 0.220 & 2.72 & 2.65 & 0.153 & 0.080 & 7.24 \\
\hline $4 / 14 / 2009$ & 1131 & 58.90 & 11.60 & 10.00 & 79.60 & 140 & 0.20 & 0 & 88.0 & 110.0 & 0.060 & 2.25 & 2.25 & 0.276 & 0.060 & 6.73 \\
\hline 4/17/2009 & 1251 & 58.80 & 12.00 & 11.00 & 86.10 & 140 & 0.20 & 0 & 84.0 & 120.0 & 0.030 & 1.87 & 1.87 & 0.153 & 0.060 & 7.51 \\
\hline $4 / 23 / 2009$ & 1121 & 40.00 & 8.00 & 8.00 & 67.80 & 90 & 0.20 & 0 & 68.0 & 98.0 & 0.040 & 1.01 & 1.01 & 0.184 & 0.080 & 5.28 \\
\hline $4 / 27 / 2009$ & 1141 & 26.40 & 5.37 & 6.00 & 40.50 & 85 & 0.10 & 0 & 27.0 & 47.0 & 0.040 & 1.38 & 1.38 & 0.245 & 0.100 & 3.20 \\
\hline $5 / 4 / 2009$ & 1056 & 32.60 & 6.56 & 7.00 & 38.20 & 71 & 0.10 & 0 & 24.0 & 86.0 & 0.030 & 0.62 & 0.62 & 0.123 & 0.050 & 3.23 \\
\hline $5 / 19 / 2009$ & 1021 & 46.70 & 9.38 & 7.00 & 51.20 & 160 & 0.10 & 0 & 29.0 & 68.0 & 0.030 & 1.76 & 1.76 & 0.245 & 0.081 & 2.16 \\
\hline \multicolumn{17}{|c|}{ Diverted SW, PAC building } \\
\hline $4 / 3 / 2009$ & 1011 & 50.53 & 10.50 & 11.03 & 39.89 & 117 & 0.14 & 0 & 69.2 & 31.0 & 0.580 & 2.83 & 2.74 & 1.104 & 0.360 & 19.00 \\
\hline $4 / 14 / 2009$ & 1011 & 45.21 & 9.84 & 9.28 & 36.13 & 129 & 0.16 & 0 & 63.3 & 27.3 & 0.170 & 1.84 & 1.78 & 0.889 & 0.300 & 26.30 \\
\hline $4 / 17 / 2009$ & 0951 & 73.87 & 14.77 & 9.91 & 59.90 & 188 & 0.26 & 0 & 104.2 & 38.6 & 0.060 & 1.35 & 1.30 & 0.797 & 0.230 & 24.20 \\
\hline
\end{tabular}

${ }^{* *}$ Values may be reported as estimated (E) if values are out of instrument calibration range, data quantification was not performed according to method specific criteria, or deviation for the standard operating procedure was required. Values are considered detections. (Childress and others, 1999). 
Table 9. Summary of trace element and atrazine concentrations from water samples collected as part of the Equus Beds Experimental Passive Recharge Project at RB1, 2009-2010.

$\left[\mu \mathrm{g} / \mathrm{L}\right.$, micrograms per liter; --, not determined or not applicable; $\mathrm{M}^{*}$, presence of material verified, but not quantified; $\mathrm{E}^{* *}$, estimated: $<$, less than; >, greater than]

\begin{tabular}{|c|c|c|c|c|c|c|}
\hline $\begin{array}{c}\text { Date of sample } \\
\text { collection } \\
\text { (month/day/year) }\end{array}$ & $\begin{array}{c}\text { Sample } \\
\text { start } \\
\text { time }\end{array}$ & $\begin{array}{l}\text { Iron } \\
\text { ( } \mu \mathrm{g} / \mathrm{L})\end{array}$ & $\begin{array}{c}\text { Manganese } \\
(\mu \mathrm{g} / \mathrm{L})\end{array}$ & $\begin{array}{c}\text { Arsenic } \\
(\mu \mathrm{g} / \mathrm{L})\end{array}$ & $\begin{array}{c}\text { Atrazine, } \\
\text { recoverable } \\
\text { ( } \mu \mathrm{g} / \mathrm{L})\end{array}$ & $\begin{array}{l}\text { Triazine screen, } \\
\text { enzyme link } \\
\text { immuno sorbent } \\
\text { assay, recoverable } \\
(\mu \mathrm{g} / \mathrm{L})\end{array}$ \\
\hline \multicolumn{7}{|c|}{ IW-09 shallow } \\
\hline $3 / 19 / 2002$ & 1100 & -- & -- & -- & -- & $<0.10$ \\
\hline $3 / 19 / 2002$ & 1101 & $<5$ & 100 & $<1.00$ & -- & -- \\
\hline $6 / 20 / 2002$ & 0935 & -- & -- & -- & 0.011 & $<0.10$ \\
\hline $6 / 20 / 2002$ & 0936 & $<5$ & 120 & $<1.00$ & -- & -- \\
\hline $2 / 14 / 2003$ & 1035 & -- & -- & -- & -- & $<0.10$ \\
\hline $2 / 14 / 2003$ & 1036 & M & 250 & $<1.00$ & -- & -- \\
\hline $2 / 14 / 2003$ & 1037 & -- & -- & -- & -- & $<0.10$ \\
\hline $6 / 25 / 2003$ & 0855 & -- & -- & -- & 0.009 & $<0.10$ \\
\hline $6 / 25 / 2003$ & 0856 & $<5$ & 360 & $<1.00$ & -- & -- \\
\hline $6 / 25 / 2003$ & 0905 & $<8$ & 362 & -- & -- & -- \\
\hline $2 / 10 / 2004$ & 1030 & -- & -- & -- & -- & $<0.10$ \\
\hline $2 / 10 / 2004$ & 1031 & $<5$ & 300 & $<1.00$ & -- & -- \\
\hline $6 / 25 / 2004$ & 0925 & -- & -- & -- & -- & $<0.10$ \\
\hline $6 / 25 / 2004$ & 0926 & $<5$ & 330 & 1.20 & -- & -- \\
\hline $7 / 11 / 2005$ & 1200 & -- & -- & -- & -- & $<0.10$ \\
\hline $7 / 11 / 2005$ & 1201 & $<5$ & 360 & $<1.00$ & -- & -- \\
\hline $6 / 14 / 2006$ & 1045 & -- & -- & -- & -- & $<0.10$ \\
\hline $6 / 14 / 2006$ & 1046 & $<50$ & 170 & $<1.00$ & -- & -- \\
\hline $6 / 14 / 2006$ & 1050 & E5 & 159 & 0.65 & -- & -- \\
\hline $6 / 20 / 2007$ & 1020 & -- & -- & -- & 0.014 & $<0.10$ \\
\hline $6 / 20 / 2007$ & 1021 & $<100$ & 26 & $<1.00$ & -- & -- \\
\hline $6 / 12 / 2008$ & 0940 & -- & -- & -- & -- & $<0.10$ \\
\hline $6 / 12 / 2008$ & 0941 & $<100$ & 426 & $<1.00$ & -- & -- \\
\hline $2 / 10 / 2009$ & 0955 & -- & -- & -- & -- & $<0.10$ \\
\hline $2 / 10 / 2009$ & 0956 & $<100$ & 339 & $<1.00$ & -- & -- \\
\hline $4 / 2 / 2009$ & 1055 & -- & -- & -- & -- & $<0.10$ \\
\hline 4/2/2009 & 1056 & $<100$ & 259 & $<1.00$ & -- & -- \\
\hline $4 / 22 / 2009$ & 1020 & -- & -- & -- & -- & $<0.10$ \\
\hline $4 / 22 / 2009$ & 1021 & $<100$ & 255 & $<1.00$ & -- & -- \\
\hline $6 / 10 / 2009$ & 0955 & -- & -- & -- & -- & $<0.10$ \\
\hline $6 / 10 / 2009$ & 0956 & $<100$ & 376 & $<1.00$ & -- & -- \\
\hline $6 / 10 / 2009$ & 1000 & $<4$ & 337 & 1.00 & -- & -- \\
\hline $7 / 14 / 2009$ & 1020 & -- & -- & -- & -- & $<0.10$ \\
\hline $7 / 14 / 2009$ & 1021 & $<100$ & 345 & $<1.00$ & -- & -- \\
\hline 8/19/2009 & 1000 & -- & -- & -- & -- & $<0.10$ \\
\hline $8 / 19 / 2009$ & 1001 & $<100$ & 321 & $<1.00$ & -- & -- \\
\hline $11 / 17 / 2009$ & 1005 & -- & -- & -- & -- & $<0.10$ \\
\hline $11 / 17 / 2009$ & 1006 & $<100$ & 295 & $<1.00$ & -- & -- \\
\hline $3 / 9 / 2010$ & 1010 & -- & -- & -- & -- & $<0.10$ \\
\hline $3 / 9 / 2010$ & 1011 & $<100$ & 229 & 2.70 & -- & -- \\
\hline \multicolumn{7}{|c|}{ IW-09 deep } \\
\hline $3 / 19 / 2002$ & 1305 & -- & -- & -- & -- & $<0.10$ \\
\hline $3 / 19 / 2002$ & 1306 & 80 & 400 & 16.90 & -- & -- \\
\hline $6 / 24 / 2002$ & 1045 & -- & -- & -- & -- & $<0.10$ \\
\hline $6 / 24 / 2002$ & 1046 & 100 & 410 & 17.00 & -- & -- \\
\hline $2 / 14 / 2003$ & 1335 & -- & -- & -- & -- & $<0.10$ \\
\hline $2 / 14 / 2003$ & 1336 & 120 & 440 & 16.60 & -- & -- \\
\hline $6 / 25 / 2003$ & 1135 & -- & -- & -- & $<0.007$ & $<0.10$ \\
\hline $6 / 25 / 2003$ & 1136 & 70 & 380 & 16.20 & -- & -- \\
\hline $6 / 25 / 2003$ & 1145 & 70 & 380 & -- & -- & -- \\
\hline
\end{tabular}


Table 9. Summary of trace element and atrazine concentrations from water samples collected as part of the Equus Beds Experimental Passive Recharge Project at RB1, 2009-2010._Continued

$\left[\mu \mathrm{g} / \mathrm{L}\right.$, micrograms per liter; --, not determined or not applicable; $\mathrm{M}^{*}$, presence of material verified, but not quantified; $\mathrm{E}^{* *}$, estimated: $<$, less than; >, greater than]

\begin{tabular}{|c|c|c|c|c|c|c|}
\hline $\begin{array}{c}\text { Date of sample } \\
\text { collection } \\
\text { (month/day/year) }\end{array}$ & $\begin{array}{c}\text { Sample } \\
\text { start } \\
\text { time }\end{array}$ & $\begin{array}{l}\text { Iron } \\
\text { ( } \mu \mathrm{g} / \mathrm{L})\end{array}$ & $\begin{array}{c}\text { Manganese } \\
(\mu \mathrm{g} / \mathrm{L})\end{array}$ & $\begin{array}{c}\text { Arsenic } \\
\text { ( } \mu \mathrm{g} / \mathrm{L})\end{array}$ & $\begin{array}{c}\text { Atrazine, } \\
\text { recoverable } \\
\text { ( } \mu \mathrm{g} / \mathrm{L})\end{array}$ & $\begin{array}{l}\text { Triazine screen, } \\
\text { enzyme link } \\
\text { immuno sorbent } \\
\text { assay, recoverable } \\
(\mu \mathrm{g} / \mathrm{L})\end{array}$ \\
\hline \multicolumn{7}{|c|}{ IW-09 deep-Continued } \\
\hline $2 / 10 / 2004$ & 1225 & -- & -- & -- & -- & $<0.10$ \\
\hline $2 / 10 / 2004$ & 1226 & 100 & 430 & 19.50 & -- & -- \\
\hline $2 / 10 / 2004$ & 1227 & -- & -- & -- & -- & $<0.10$ \\
\hline $6 / 25 / 2004$ & 1130 & -- & -- & -- & -- & $<0.10$ \\
\hline $6 / 25 / 2004$ & 1131 & 100 & 430 & 21.00 & -- & -- \\
\hline $6 / 25 / 2004$ & 1132 & -- & -- & -- & -- & $<0.10$ \\
\hline $7 / 11 / 2005$ & 1030 & -- & -- & -- & -- & $<0.10$ \\
\hline $7 / 11 / 2005$ & 1031 & 80 & 420 & 14.00 & -- & -- \\
\hline $6 / 14 / 2006$ & 1235 & -- & -- & -- & -- & $<0.10$ \\
\hline $6 / 14 / 2006$ & 1236 & 100 & 450 & 18.30 & -- & -- \\
\hline $6 / 20 / 2007$ & 1220 & -- & -- & -- & $<0.007$ & $<0.10$ \\
\hline $6 / 20 / 2007$ & 1221 & $<100$ & 421 & 19.00 & -- & -- \\
\hline $6 / 12 / 2008$ & 1110 & -- & -- & -- & -- & $<0.10$ \\
\hline $6 / 12 / 2008$ & 1111 & $<100$ & 469 & 21.00 & -- & -- \\
\hline $2 / 10 / 2009$ & 1125 & -- & -- & -- & -- & $<0.10$ \\
\hline $2 / 10 / 2009$ & 1126 & 110 & 469 & 14.00 & -- & -- \\
\hline $4 / 2 / 2009$ & 1215 & -- & -- & -- & -- & $<0.10$ \\
\hline $4 / 2 / 2009$ & 1216 & 110 & 486 & 13.00 & -- & -- \\
\hline $4 / 22 / 2009$ & 1200 & -- & -- & -- & -- & $<0.10$ \\
\hline $4 / 22 / 2009$ & 1201 & $<100$ & 472 & 17.00 & -- & -- \\
\hline $6 / 10 / 2009$ & 1120 & -- & -- & -- & -- & $<0.10$ \\
\hline $6 / 10 / 2009$ & 1121 & $<100$ & 459 & 16.00 & -- & -- \\
\hline $6 / 10 / 2009$ & 1125 & 82 & 424 & 17.50 & -- & -- \\
\hline $7 / 14 / 2009$ & 1150 & -- & -- & -- & -- & $<0.10$ \\
\hline $7 / 14 / 2009$ & 1151 & 110 & 473 & 18.00 & -- & -- \\
\hline $8 / 19 / 2009$ & 1150 & -- & -- & -- & -- & $<0.10$ \\
\hline 8/19/2009 & 1151 & $<100$ & 473 & 16.00 & -- & -- \\
\hline $11 / 17 / 2009$ & 1145 & -- & -- & -- & -- & $<0.10$ \\
\hline $11 / 17 / 2009$ & 1146 & 100 & 485 & 17.00 & -- & -- \\
\hline 3/9/2010 & 1155 & -- & -- & -- & -- & $<0.10$ \\
\hline $3 / 9 / 2010$ & 1156 & 120 & 517 & 19.20 & -- & -- \\
\hline \multicolumn{7}{|c|}{ RB1 source water } \\
\hline $8 / 3 / 2007$ & 1105 & -- & -- & -- & 0.114 & 0.10 \\
\hline $8 / 3 / 2007$ & 1106 & $<100$ & $<5$ & $<1.00$ & -- & -- \\
\hline $8 / 3 / 2007$ & 1107 & -- & -- & -- & -- & 0.13 \\
\hline $8 / 3 / 2007$ & 1115 & -- & -- & -- & 0.114 & $<0.10$ \\
\hline $8 / 3 / 2007$ & 1116 & $<100$ & $<5$ & $<1.00$ & -- & -- \\
\hline $4 / 3 / 2009$ & 1215 & -- & -- & -- & -- & 0.42 \\
\hline $4 / 3 / 2009$ & 1216 & $<100$ & 61 & $<1.00$ & -- & -- \\
\hline $4 / 14 / 2009$ & 1140 & -- & -- & -- & 0.050 & 0.66 \\
\hline $4 / 14 / 2009$ & 1141 & $<100$ & $<5$ & $<1.00$ & -- & -- \\
\hline $4 / 17 / 2009$ & 1110 & -- & -- & -- & -- & 0.27 \\
\hline $4 / 17 / 2009$ & 1111 & $<100$ & 7 & $<1.00$ & -- & -- \\
\hline \multicolumn{7}{|c|}{ RB1-MN shallow } \\
\hline $8 / 30 / 2006$ & 1010 & -- & -- & -- & $<0.007$ & $<0.10$ \\
\hline $8 / 30 / 2006$ & 1011 & 2,910 & 360 & 9.10 & -- & -- \\
\hline $8 / 30 / 2006$ & 1015 & -- & -- & -- & -- & \\
\hline $11 / 29 / 2006$ & 1100 & -- & -- & -- & -- & $<0.10$ \\
\hline $11 / 29 / 2006$ & 1101 & 3,910 & 290 & 9.10 & -- & -- \\
\hline $2 / 23 / 2007$ & 1010 & -- & -- & -- & -- & $<0.10$ \\
\hline $2 / 23 / 2007$ & 1011 & 4,300 & 290 & 7.80 & -- & -- \\
\hline
\end{tabular}


Table 9. Summary of trace element and atrazine concentrations from water samples collected as part of the Equus Beds Experimental Passive Recharge Project at RB1, 2009-2010.-Continued

$\left[\mu \mathrm{g} / \mathrm{L}\right.$, micrograms per liter; --, not determined or not applicable; $\mathrm{M}^{*}$, presence of material verified, but not quantified; $\mathrm{E}^{* *}$, estimated: $<$, less than; >, greater than]

\begin{tabular}{|c|c|c|c|c|c|c|}
\hline $\begin{array}{c}\text { Date of sample } \\
\text { collection } \\
\text { (month/day/year) }\end{array}$ & $\begin{array}{c}\text { Sample } \\
\text { start } \\
\text { time }\end{array}$ & $\begin{array}{l}\text { Iron } \\
(\mu \mathrm{g} / \mathrm{L})\end{array}$ & $\begin{array}{c}\text { Manganese } \\
(\mu \mathrm{g} / \mathrm{L})\end{array}$ & $\begin{array}{c}\text { Arsenic } \\
\text { ( } \mu \mathrm{g} / \mathrm{L})\end{array}$ & $\begin{array}{c}\text { Atrazine, } \\
\text { recoverable } \\
\text { ( } \mu \mathrm{g} / \mathrm{L})\end{array}$ & $\begin{array}{l}\text { Triazine screen, } \\
\text { enzyme link } \\
\text { immuno sorbent } \\
\text { assay, recoverable } \\
(\mu \mathrm{g} / \mathrm{L})\end{array}$ \\
\hline \multicolumn{7}{|c|}{ RB1-MN shallow-Continued } \\
\hline $6 / 4 / 2007$ & 1015 & -- & -- & -- & -- & $<0.10$ \\
\hline $6 / 4 / 2007$ & 1016 & 4,150 & 277 & 9.00 & -- & -- \\
\hline $6 / 4 / 2007$ & 1017 & -- & -- & -- & -- & $<0.10$ \\
\hline $8 / 29 / 2007$ & 1020 & -- & -- & -- & $<0.007$ & $<0.10$ \\
\hline $8 / 29 / 2007$ & 1021 & 4,040 & 262 & 7.00 & -- & -- \\
\hline $8 / 29 / 2007$ & 1030 & -- & -- & -- & $<0.007$ & $<0.10$ \\
\hline $8 / 29 / 2007$ & 1031 & 4,070 & 263 & 8.00 & -- & -- \\
\hline $3 / 5 / 2008$ & 1025 & -- & -- & -- & -- & $<0.10$ \\
\hline $3 / 5 / 2008$ & 1026 & 4,570 & 290 & 7.00 & -- & -- \\
\hline $3 / 5 / 2008$ & 1030 & -- & -- & -- & -- & $<0.10$ \\
\hline $3 / 5 / 2008$ & 1031 & 4,570 & 290 & 8.00 & -- & -- \\
\hline $8 / 19 / 2008$ & 1010 & -- & -- & -- & $<0.007$ & $<0.10$ \\
\hline $8 / 19 / 2008$ & 1011 & 4,260 & 271 & 8.00 & -- & -- \\
\hline 2/9/2009 & 1020 & -- & -- & -- & -- & $<0.10$ \\
\hline $2 / 9 / 2009$ & 1021 & 4,670 & 300 & 7.00 & -- & -- \\
\hline $4 / 1 / 2009$ & 1110 & -- & -- & -- & -- & $<0.10$ \\
\hline 4/1/2009 & 1111 & 4,730 & 306 & 7.00 & -- & -- \\
\hline $4 / 21 / 2009$ & 0955 & -- & -- & -- & -- & $<0.10$ \\
\hline $4 / 21 / 2009$ & 0956 & 4,760 & 310 & 8.00 & -- & -- \\
\hline $6 / 25 / 2009$ & 1000 & -- & -- & -- & $<0.007$ & $<0.10$ \\
\hline $6 / 25 / 2009$ & 1001 & 4,740 & 311 & 7.00 & -- & -- \\
\hline $7 / 14 / 2009$ & 1025 & -- & -- & -- & -- & $<0.10$ \\
\hline $7 / 14 / 2009$ & 1026 & 4,370 & 281 & 8.00 & -- & -- \\
\hline $8 / 19 / 2009$ & 0955 & -- & -- & -- & -- & $<0.10$ \\
\hline $8 / 19 / 2009$ & 0956 & 4,270 & 271 & 7.00 & -- & -- \\
\hline $8 / 19 / 2009$ & 0957 & -- & -- & -- & -- & $<0.10$ \\
\hline $11 / 18 / 2009$ & 1000 & -- & -- & -- & -- & $<0.10$ \\
\hline $11 / 18 / 2009$ & 1001 & 4,700 & 306 & 8.00 & -- & -- \\
\hline $3 / 8 / 2010$ & 1005 & -- & -- & -- & -- & $<0.10$ \\
\hline $3 / 8 / 2010$ & 1006 & 4,590 & 299 & 10.60 & -- & -- \\
\hline \multicolumn{7}{|c|}{ RB1-MN deep } \\
\hline $8 / 30 / 2006$ & 1155 & -- & -- & -- & $<0.007$ & $<0.10$ \\
\hline $8 / 30 / 2006$ & 1156 & 640 & 420 & 16.60 & -- & -- \\
\hline $11 / 29 / 2006$ & 0955 & -- & -- & -- & -- & $<0.10$ \\
\hline $11 / 29 / 2006$ & 0956 & 770 & 420 & 16.00 & -- & -- \\
\hline $2 / 23 / 2007$ & 1205 & -- & -- & -- & -- & $<0.10$ \\
\hline $2 / 23 / 2007$ & 1206 & 750 & 390 & 14.00 & -- & -- \\
\hline $6 / 4 / 2007$ & 1140 & -- & -- & -- & -- & $<0.10$ \\
\hline $6 / 4 / 2007$ & 1141 & 720 & 368 & 15.00 & -- & -- \\
\hline $6 / 4 / 2007$ & 1145 & -- & -- & -- & -- & $<0.10$ \\
\hline $6 / 4 / 2007$ & 1146 & 730 & 370 & 16.00 & -- & -- \\
\hline $8 / 29 / 2007$ & 1230 & -- & -- & -- & $<0.007$ & $<0.10$ \\
\hline $8 / 29 / 2007$ & 1231 & 800 & 407 & 12.00 & -- & -- \\
\hline $3 / 5 / 2008$ & 1155 & -- & -- & -- & -- & $<0.10$ \\
\hline $3 / 5 / 2008$ & 1156 & 880 & 418 & 14.00 & -- & -- \\
\hline $8 / 19 / 2008$ & 1150 & -- & -- & -- & $<0.007$ & $<0.10$ \\
\hline $8 / 19 / 2008$ & 1151 & 1,050 & 435 & 14.00 & -- & -- \\
\hline 2/9/2009 & 1150 & -- & -- & -- & -- & $<0.10$ \\
\hline 2/9/2009 & 1151 & 920 & 433 & 13.00 & -- & -- \\
\hline $4 / 1 / 2009$ & 1240 & -- & -- & -- & -- & $<0.10$ \\
\hline $4 / 1 / 2009$ & 1241 & 850 & 432 & 13.00 & -- & -- \\
\hline
\end{tabular}


Table 9. Summary of trace element and atrazine concentrations from water samples collected as part of the Equus Beds Experimental Passive Recharge Project at RB1, 2009-2010._Continued

$\left[\mu \mathrm{g} / \mathrm{L}\right.$, micrograms per liter; --, not determined or not applicable; $\mathrm{M}^{*}$, presence of material verified, but not quantified; $\mathrm{E}^{* *}$, estimated: $<$, less than; >, greater than]

\begin{tabular}{|c|c|c|c|c|c|c|}
\hline $\begin{array}{c}\text { Date of sample } \\
\text { collection } \\
\text { (month/day/year) }\end{array}$ & $\begin{array}{c}\text { Sample } \\
\text { start } \\
\text { time }\end{array}$ & $\begin{array}{l}\text { Iron } \\
(\mu \mathrm{g} / \mathrm{L})\end{array}$ & $\begin{array}{c}\text { Manganese } \\
(\mu \mathrm{g} / \mathrm{L})\end{array}$ & $\begin{array}{c}\text { Arsenic } \\
(\mu \mathrm{g} / \mathrm{L})\end{array}$ & $\begin{array}{c}\text { Atrazine, } \\
\text { recoverable } \\
(\mu \mathrm{g} / \mathrm{L})\end{array}$ & $\begin{array}{l}\text { Triazine screen, } \\
\text { enzyme link } \\
\text { immuno sorbent } \\
\text { assay, recoverable } \\
(\mu \mathrm{g} / \mathrm{L})\end{array}$ \\
\hline \multicolumn{7}{|c|}{ RB1-MN deep-Continued } \\
\hline $4 / 1 / 2009$ & 1242 & -- & -- & -- & -- & $<0.10$ \\
\hline $4 / 21 / 2009$ & 1115 & -- & -- & -- & -- & $<0.10$ \\
\hline $4 / 21 / 2009$ & 1116 & 840 & 398 & 14.0 & -- & -- \\
\hline $6 / 25 / 2009$ & 1200 & -- & -- & -- & $<0.007$ & $<0.10$ \\
\hline $6 / 25 / 2009$ & 1201 & 840 & 400 & 14.0 & -- & -- \\
\hline $6 / 25 / 2009$ & 1210 & -- & -- & -- & $<0.007$ & $<0.10$ \\
\hline $6 / 25 / 2009$ & 1211 & 840 & 403 & 14.0 & -- & -- \\
\hline $7 / 14 / 2009$ & 1200 & -- & -- & -- & -- & $<0.10$ \\
\hline $7 / 14 / 2009$ & 1201 & 920 & 435 & 14.0 & -- & -- \\
\hline $8 / 19 / 2009$ & 1125 & -- & -- & -- & -- & $<0.10$ \\
\hline $8 / 19 / 2009$ & 1126 & 850 & 408 & 14.0 & -- & -- \\
\hline $11 / 18 / 2009$ & 1130 & -- & -- & -- & -- & $<0.10$ \\
\hline $11 / 18 / 2009$ & 1131 & 960 & 452 & 14.0 & -- & -- \\
\hline $3 / 8 / 2010$ & 1145 & -- & -- & -- & -- & $<0.10$ \\
\hline $3 / 8 / 2010$ & 1146 & 870 & 407 & 16.7 & -- & -- \\
\hline \multicolumn{7}{|c|}{ RB1-MS shallow } \\
\hline $8 / 30 / 2006$ & 1030 & -- & -- & -- & E0.002 & $<0.10$ \\
\hline $8 / 30 / 2006$ & 1031 & 800 & 170 & 7.10 & -- & -- \\
\hline $8 / 30 / 2006$ & 1035 & -- & -- & -- & -- & -- \\
\hline $11 / 29 / 2006$ & 1010 & -- & -- & -- & -- & $<0.10$ \\
\hline $11 / 29 / 2006$ & 1011 & 1,000 & 150 & 6.20 & -- & -- \\
\hline $2 / 23 / 2007$ & 1030 & -- & -- & -- & -- & $<0.10$ \\
\hline $2 / 23 / 2007$ & 1031 & 1,140 & 160 & 5.00 & -- & -- \\
\hline $2 / 23 / 2007$ & 1032 & -- & -- & -- & -- & $<0.10$ \\
\hline $6 / 4 / 2007$ & 1020 & -- & -- & -- & -- & $<0.10$ \\
\hline $6 / 4 / 2007$ & 1021 & 970 & 140 & 5.00 & -- & -- \\
\hline $8 / 29 / 2007$ & 1015 & -- & -- & -- & $<0.007$ & $<0.10$ \\
\hline $8 / 29 / 2007$ & 1016 & 970 & 131 & 5.00 & -- & -- \\
\hline $3 / 4 / 2008$ & 1015 & -- & -- & -- & E0.004 & $<0.10$ \\
\hline $3 / 4 / 2008$ & 1016 & 1,020 & 125 & 5.00 & -- & -- \\
\hline $8 / 18 / 2008$ & 1030 & -- & -- & -- & E0.003 & $<0.10$ \\
\hline $8 / 18 / 2008$ & 1031 & 1,050 & 124 & 6.00 & -- & -- \\
\hline $8 / 18 / 2008$ & 1032 & -- & -- & -- & -- & $<0.10$ \\
\hline $2 / 4 / 2009$ & 1005 & -- & -- & -- & -- & $<0.10$ \\
\hline 2/4/2009 & 1006 & 1,170 & 120 & 5.00 & -- & -- \\
\hline $3 / 24 / 2009$ & 1135 & -- & -- & -- & -- & $<0.10$ \\
\hline $3 / 24 / 2009$ & 1136 & 1,150 & 116 & 4.00 & -- & -- \\
\hline $4 / 6 / 2009$ & 1010 & -- & -- & -- & -- & $<0.10$ \\
\hline $4 / 6 / 2009$ & 1011 & 1,180 & 120 & 5.00 & -- & -- \\
\hline $4 / 9 / 2009$ & 1005 & -- & -- & -- & $<0.050$ & $<0.10$ \\
\hline 4/9/2009 & 1006 & 1,180 & 118 & 4.00 & -- & -- \\
\hline $4 / 16 / 2009$ & 1015 & -- & -- & -- & -- & $<0.10$ \\
\hline 4/16/2009 & 1016 & 1,160 & 117 & 5.00 & -- & \\
\hline $4 / 20 / 2009$ & 1005 & -- & -- & -- & -- & $<0.10$ \\
\hline $4 / 20 / 2009$ & 1006 & 1,130 & 114 & 5.00 & -- & -- \\
\hline $5 / 6 / 2009$ & 1025 & -- & -- & -- & $<0.050$ & $<0.10$ \\
\hline $5 / 6 / 2009$ & 1026 & 1,150 & 115 & 5.00 & -- & -- \\
\hline $5 / 20 / 2009$ & 1005 & -- & -- & -- & -- & $<0.10$ \\
\hline $5 / 20 / 2009$ & 1006 & 1,110 & 117 & 5.00 & -- & -- \\
\hline $6 / 25 / 2009$ & 1000 & -- & -- & -- & E0.006 & $<0.10$ \\
\hline $6 / 25 / 2009$ & 1001 & 1,150 & 116 & 4.00 & -- & -- \\
\hline
\end{tabular}


Table 9. Summary of trace element and atrazine concentrations from water samples collected as part of the Equus Beds Experimental Passive Recharge Project at RB1, 2009-2010.-Continued

$\left[\mu \mathrm{g} / \mathrm{L}\right.$, micrograms per liter; --, not determined or not applicable; $\mathrm{M}^{*}$, presence of material verified, but not quantified; $\mathrm{E}^{* *}$, estimated: $<$, less than; >, greater than]

\begin{tabular}{|c|c|c|c|c|c|c|}
\hline $\begin{array}{c}\text { Date of sample } \\
\text { collection } \\
\text { (month/day/year) }\end{array}$ & $\begin{array}{c}\text { Sample } \\
\text { start } \\
\text { time }\end{array}$ & $\begin{array}{l}\text { Iron } \\
\text { ( } \mu \mathrm{g} / \mathrm{L})\end{array}$ & $\begin{array}{c}\text { Manganese } \\
(\mu \mathrm{g} / \mathrm{L})\end{array}$ & $\begin{array}{c}\text { Arsenic } \\
(\mu \mathrm{g} / \mathrm{L})\end{array}$ & $\begin{array}{c}\text { Atrazine, } \\
\text { recoverable } \\
\text { ( } \mu \mathrm{g} / \mathrm{L})\end{array}$ & $\begin{array}{l}\text { Triazine screen, } \\
\text { enzyme link } \\
\text { immuno sorbent } \\
\text { assay, recoverable } \\
(\mu \mathrm{g} / \mathrm{L})\end{array}$ \\
\hline \multicolumn{7}{|c|}{ RB1-MS shallow-Continued } \\
\hline $7 / 8 / 2009$ & 1020 & -- & -- & -- & -- & $<0.10$ \\
\hline $7 / 8 / 2009$ & 1021 & 1,210 & 115 & 4.00 & -- & -- \\
\hline $7 / 13 / 2009$ & 1015 & -- & -- & -- & -- & $<0.10$ \\
\hline $7 / 13 / 2009$ & 1016 & 1,150 & 110 & 5.00 & -- & -- \\
\hline $7 / 20 / 2009$ & 1015 & -- & -- & -- & -- & $<0.10$ \\
\hline $7 / 20 / 2009$ & 1016 & 1,040 & 105 & 4.00 & -- & -- \\
\hline $8 / 18 / 2009$ & 1010 & -- & -- & -- & -- & $<0.10$ \\
\hline $8 / 18 / 2009$ & 1011 & 1,180 & 113 & 4.00 & -- & -- \\
\hline $11 / 18 / 2009$ & 1005 & -- & -- & -- & -- & $<0.10$ \\
\hline $11 / 18 / 2009$ & 1006 & 1,140 & 111 & 5.00 & -- & -- \\
\hline $3 / 1 / 2010$ & 1130 & -- & -- & -- & -- & $<0.10$ \\
\hline $3 / 1 / 2010$ & 1131 & 1,120 & 109 & 5.50 & -- & -- \\
\hline \multicolumn{7}{|c|}{ RB1-MS deep } \\
\hline $8 / 30 / 2006$ & 1245 & -- & -- & -- & $<0.007$ & $<0.10$ \\
\hline $8 / 30 / 2006$ & 1246 & 180 & 420 & 20.3 & -- & -- \\
\hline $12 / 4 / 2006$ & 1000 & -- & -- & -- & -- & $<0.10$ \\
\hline $12 / 4 / 2006$ & 1001 & 200 & 410 & 17.9 & -- & -- \\
\hline $2 / 23 / 2007$ & 1145 & -- & -- & -- & -- & $<0.10$ \\
\hline $2 / 23 / 2007$ & 1146 & 230 & 430 & 15.0 & -- & -- \\
\hline $6 / 4 / 2007$ & 1150 & -- & -- & -- & -- & $<0.10$ \\
\hline $6 / 4 / 2007$ & 1151 & 220 & 412 & 17.0 & -- & -- \\
\hline $8 / 29 / 2007$ & 1205 & -- & -- & -- & $<0.007$ & $<0.10$ \\
\hline $8 / 29 / 2007$ & 1206 & 230 & 425 & 13.0 & -- & -- \\
\hline $3 / 4 / 2008$ & 1200 & -- & -- & -- & $<0.007$ & $<0.10$ \\
\hline $3 / 4 / 2008$ & 1201 & 250 & 414 & 16.0 & -- & -- \\
\hline $8 / 18 / 2008$ & 1230 & -- & -- & -- & $<0.007$ & $<0.10$ \\
\hline $8 / 18 / 2008$ & 1231 & 250 & 440 & 17.0 & -- & -- \\
\hline $2 / 4 / 2009$ & 1140 & -- & -- & -- & -- & $<0.10$ \\
\hline $2 / 4 / 2009$ & 1141 & 220 & 389 & 14.0 & -- & -- \\
\hline $3 / 24 / 2009$ & 1305 & -- & -- & -- & -- & $<0.10$ \\
\hline $3 / 24 / 2009$ & 1306 & 240 & 418 & 16.0 & -- & -- \\
\hline 4/6/2009 & 1140 & -- & -- & -- & -- & $<0.10$ \\
\hline $4 / 6 / 2009$ & 1141 & 240 & 413 & 15.0 & -- & -- \\
\hline 4/9/2009 & 1135 & -- & -- & -- & $<0.050$ & $<0.10$ \\
\hline 4/9/2009 & 1136 & 230 & 410 & 15.0 & -- & -- \\
\hline $4 / 16 / 2009$ & 1140 & -- & -- & -- & -- & $<0.10$ \\
\hline $4 / 16 / 2009$ & 1141 & 230 & 408 & 16.0 & -- & -- \\
\hline $4 / 20 / 2009$ & 1135 & -- & -- & -- & -- & $<0.10$ \\
\hline $4 / 20 / 2009$ & 1136 & 230 & 414 & 16.0 & -- & -- \\
\hline $5 / 6 / 2009$ & 1150 & -- & -- & -- & $<0.050$ & $<0.10$ \\
\hline $5 / 6 / 2009$ & 1151 & 240 & 413 & 15.0 & -- & -- \\
\hline $5 / 20 / 2009$ & 1140 & -- & -- & -- & -- & $<0.10$ \\
\hline $5 / 20 / 2009$ & 1141 & 230 & 405 & 15.0 & -- & -- \\
\hline $6 / 25 / 2009$ & 1145 & -- & -- & -- & $<0.007$ & $<0.10$ \\
\hline $6 / 25 / 2009$ & 1146 & 240 & 416 & 15.0 & -- & -- \\
\hline 7/8/2009 & 1205 & -- & -- & -- & -- & $<0.10$ \\
\hline 7/8/2009 & 1206 & 230 & 410 & 14.0 & -- & -- \\
\hline $7 / 13 / 2009$ & 1155 & -- & -- & -- & -- & $<0.10$ \\
\hline $7 / 13 / 2009$ & 1156 & 220 & 400 & 16.0 & -- & -- \\
\hline $7 / 20 / 2009$ & 1240 & -- & -- & -- & -- & $<0.10$ \\
\hline $7 / 20 / 2009$ & 1241 & 230 & 400 & 17.0 & -- & -- \\
\hline
\end{tabular}


Table 9. Summary of trace element and atrazine concentrations from water samples collected as part of the Equus Beds Experimental Passive Recharge Project at RB1, 2009-2010._Continued

$\left[\mu \mathrm{g} / \mathrm{L}\right.$, micrograms per liter; --, not determined or not applicable; $\mathrm{M}^{*}$, presence of material verified, but not quantified; $\mathrm{E}^{* *}$, estimated: $<$, less than; >, greater than]

\begin{tabular}{|c|c|c|c|c|c|c|}
\hline $\begin{array}{c}\text { Date of sample } \\
\text { collection } \\
\text { (month/day/year) }\end{array}$ & $\begin{array}{l}\text { Sample } \\
\text { start } \\
\text { time }\end{array}$ & $\begin{array}{l}\text { Iron } \\
\text { ( } \mu \mathrm{g} / \mathrm{L})\end{array}$ & $\begin{array}{c}\text { Manganese } \\
(\mu \mathrm{g} / \mathrm{L})\end{array}$ & $\begin{array}{c}\text { Arsenic } \\
(\mu \mathrm{g} / \mathrm{L})\end{array}$ & $\begin{array}{c}\text { Atrazine, } \\
\text { recoverable } \\
\text { ( } \mu \mathrm{g} / \mathrm{L})\end{array}$ & $\begin{array}{l}\text { Triazine screen, } \\
\text { enzyme link } \\
\text { immuno sorbent } \\
\text { assay, recoverable } \\
\text { ( } \mu \mathrm{g} / \mathrm{L})\end{array}$ \\
\hline \multicolumn{7}{|c|}{ RB1-MS deep-Continued } \\
\hline $8 / 18 / 2009$ & 1145 & -- & -- & -- & -- & $<0.10$ \\
\hline $8 / 18 / 2009$ & 1146 & 210 & 386 & 15.0 & -- & -- \\
\hline $11 / 18 / 2009$ & 1135 & -- & -- & -- & -- & $<0.10$ \\
\hline $11 / 18 / 2009$ & 1136 & 210 & 373 & 15.0 & -- & -- \\
\hline $3 / 1 / 2010$ & 1255 & -- & -- & -- & -- & $<0.10$ \\
\hline $3 / 1 / 2010$ & 1256 & 210 & 372 & 16.4 & -- & -- \\
\hline \multicolumn{7}{|c|}{ RB1-PMS shallow } \\
\hline $1 / 22 / 2009$ & 1415 & -- & -- & -- & -- & $<0.10$ \\
\hline $1 / 22 / 2009$ & 1416 & $<100$ & 20 & $<1.00$ & -- & -- \\
\hline $2 / 2 / 2009$ & 1035 & -- & -- & -- & -- & $<0.10$ \\
\hline $2 / 2 / 2009$ & 1036 & $<100$ & 12 & $<1.00$ & -- & -- \\
\hline $3 / 26 / 2009$ & 1115 & -- & -- & -- & -- & $<0.10$ \\
\hline $3 / 26 / 2009$ & 1116 & $<100$ & 17 & $<1.00$ & -- & -- \\
\hline $4 / 4 / 2009$ & 1005 & -- & -- & -- & -- & $<0.10$ \\
\hline $4 / 4 / 2009$ & 1006 & $<100$ & 14 & $<1.00$ & -- & -- \\
\hline 4/8/2009 & 1005 & -- & -- & -- & 0.310 & 0.50 \\
\hline $4 / 8 / 2009$ & 1006 & $<100$ & 16 & $<1.00$ & -- & -- \\
\hline $4 / 8 / 2009$ & 1010 & -- & -- & -- & -- & -- \\
\hline $4 / 15 / 2009$ & 1045 & -- & -- & -- & -- & 0.18 \\
\hline $4 / 15 / 2009$ & 1046 & $<100$ & 15 & $<1.00$ & -- & -- \\
\hline $4 / 18 / 2009$ & 1010 & -- & -- & -- & -- & 0.85 \\
\hline $4 / 18 / 2009$ & 1011 & $<100$ & 15 & $<1.00$ & -- & -- \\
\hline $5 / 6 / 2009$ & 1015 & -- & -- & -- & 0.300 & 0.29 \\
\hline $5 / 6 / 2009$ & 1016 & $<100$ & 17 & $<1.00$ & -- & -- \\
\hline $5 / 20 / 2009$ & 1020 & -- & -- & -- & -- & $<0.10$ \\
\hline $5 / 20 / 2009$ & 1021 & $<100$ & 14 & $<1.0$ & -- & -- \\
\hline $7 / 8 / 2009$ & 1125 & -- & -- & -- & -- & $<0.10$ \\
\hline 7/8/2009 & 1126 & $<100$ & 20 & $<1.00$ & -- & -- \\
\hline $7 / 13 / 2009$ & 1015 & -- & -- & -- & -- & $<0.10$ \\
\hline $7 / 13 / 2009$ & 1016 & $<100$ & 18 & 1.00 & -- & -- \\
\hline $7 / 20 / 2009$ & 1025 & -- & -- & -- & -- & $<0.10$ \\
\hline $7 / 20 / 2009$ & 1026 & $<100$ & 20 & 1.00 & -- & -- \\
\hline $8 / 18 / 2009$ & 1010 & -- & -- & -- & -- & $<0.10$ \\
\hline $8 / 18 / 2009$ & 1011 & $<100$ & 14 & $<1.00$ & -- & -- \\
\hline $11 / 17 / 2009$ & 0950 & -- & -- & -- & -- & $<0.10$ \\
\hline $11 / 17 / 2009$ & 0951 & $<100$ & 16 & $<1.00$ & -- & -- \\
\hline $3 / 2 / 2010$ & 1045 & -- & -- & -- & -- & $<0.10$ \\
\hline $3 / 2 / 2010$ & 1046 & $<100$ & 13 & 1.90 & -- & -- \\
\hline $3 / 2 / 2010$ & 1050 & -- & -- & -- & -- & $<0.10$ \\
\hline $3 / 2 / 2010$ & 1051 & $<100$ & 13 & 1.90 & -- & -- \\
\hline \multicolumn{7}{|c|}{ RB1-PMS deep } \\
\hline $1 / 22 / 2009$ & 1300 & -- & -- & -- & -- & $<0.10$ \\
\hline $1 / 22 / 2009$ & 1301 & 1170 & 195 & 4.00 & -- & -- \\
\hline $2 / 2 / 2009$ & 1205 & -- & -- & -- & -- & $<0.10$ \\
\hline $2 / 2 / 2009$ & 1206 & $<100$ & 50 & $<1.00$ & -- & -- \\
\hline $3 / 26 / 2009$ & 1240 & -- & -- & -- & -- & $<0.10$ \\
\hline $3 / 26 / 2009$ & 1241 & 100 & 34 & $<1.00$ & -- & -- \\
\hline $4 / 4 / 2009$ & 1130 & -- & -- & -- & -- & $<0.10$ \\
\hline 4/4/2009 & 1131 & $<100$ & 40 & $<1.00$ & -- & -- \\
\hline 4/8/2009 & 1130 & -- & -- & -- & 0.310 & 0.22 \\
\hline 4/8/2009 & 1131 & $<100$ & 54 & $<1.00$ & -- & -- \\
\hline
\end{tabular}


Table 9. Summary of trace element and atrazine concentrations from water samples collected as part of the Equus Beds Experimental Passive Recharge Project at RB1, 2009-2010.-Continued

$\left[\mu \mathrm{g} / \mathrm{L}\right.$, micrograms per liter; --, not determined or not applicable; $\mathrm{M}^{*}$, presence of material verified, but not quantified; $\mathrm{E}^{* *}$, estimated: $<$, less than; >, greater than]

\begin{tabular}{|c|c|c|c|c|c|c|}
\hline $\begin{array}{c}\text { Date of sample } \\
\text { collection } \\
\text { (month/day/year) }\end{array}$ & $\begin{array}{c}\text { Sample } \\
\text { start } \\
\text { time }\end{array}$ & $\begin{array}{l}\text { Iron } \\
(\mu \mathrm{g} / \mathrm{L})\end{array}$ & $\begin{array}{c}\text { Manganese } \\
(\mu \mathrm{g} / \mathrm{L})\end{array}$ & $\begin{array}{c}\text { Arsenic } \\
\text { ( } \mu \mathrm{g} / \mathrm{L})\end{array}$ & $\begin{array}{c}\text { Atrazine, } \\
\text { recoverable } \\
\text { ( } \mu \mathrm{g} / \mathrm{L})\end{array}$ & $\begin{array}{l}\text { Triazine screen, } \\
\text { enzyme link } \\
\text { immuno sorbent } \\
\text { assay, recoverable } \\
(\mu \mathrm{g} / \mathrm{L})\end{array}$ \\
\hline \multicolumn{7}{|c|}{ RB1-PMS deep-Continued } \\
\hline $4 / 15 / 2009$ & 1215 & -- & -- & -- & -- & 0.44 \\
\hline $4 / 15 / 2009$ & 1216 & $<100$ & 46 & 1.00 & -- & -- \\
\hline $4 / 15 / 2009$ & 1217 & -- & -- & -- & -- & 0.30 \\
\hline $4 / 18 / 2009$ & 1145 & -- & -- & -- & -- & 0.44 \\
\hline $4 / 18 / 2009$ & 1146 & $<100$ & 41 & $<1.00$ & -- & -- \\
\hline $5 / 6 / 2009$ & 1140 & -- & -- & -- & 0.430 & 0.46 \\
\hline $5 / 6 / 2009$ & 1141 & $<100$ & 33 & $<1.00$ & -- & -- \\
\hline $5 / 20 / 2009$ & 1150 & -- & -- & -- & -- & $<0.10$ \\
\hline $5 / 20 / 2009$ & 1151 & $<100$ & 30 & $<1.00$ & -- & -- \\
\hline $7 / 8 / 2009$ & 1005 & -- & -- & -- & -- & $<0.10$ \\
\hline 7/8/2009 & 1006 & $<100$ & 6 & $<1.00$ & -- & -- \\
\hline $7 / 13 / 2009$ & 1140 & -- & -- & -- & -- & $<0.10$ \\
\hline $7 / 13 / 2009$ & 1141 & $<100$ & 18 & 1.00 & -- & -- \\
\hline $7 / 20 / 2009$ & 1200 & -- & -- & -- & -- & $<0.10$ \\
\hline $7 / 20 / 2009$ & 1201 & $<100$ & 71 & $<1.00$ & -- & -- \\
\hline $8 / 18 / 2009$ & 1145 & -- & -- & -- & -- & $<0.10$ \\
\hline $8 / 18 / 2009$ & 1146 & $<100$ & 21 & $<1.00$ & -- & -- \\
\hline $11 / 17 / 2009$ & 1120 & -- & -- & -- & -- & $<0.10$ \\
\hline $11 / 17 / 2009$ & 1121 & $<100$ & 30 & $<1.00$ & -- & -- \\
\hline $3 / 2 / 2010$ & 1255 & -- & -- & -- & -- & $<0.10$ \\
\hline $3 / 2 / 2010$ & 1256 & $<100$ & 36 & 1.70 & -- & -- \\
\hline $3 / 22 / 2010$ & 1025 & -- & -- & -- & -- & $<0.10$ \\
\hline $3 / 22 / 2010$ & 1026 & $<100$ & 36 & 1.80 & -- & -- \\
\hline \multicolumn{7}{|c|}{ RB1-P shallow } \\
\hline $1 / 21 / 2009$ & 1500 & -- & -- & -- & -- & $<0.10$ \\
\hline $1 / 21 / 2009$ & 1501 & $<100$ & 23 & $<1.00$ & -- & -- \\
\hline $2 / 3 / 2009$ & 1015 & -- & -- & -- & -- & $<0.10$ \\
\hline $2 / 3 / 2009$ & 1016 & $<100$ & 40 & $<1.00$ & -- & -- \\
\hline $2 / 3 / 2009$ & 1017 & -- & -- & -- & -- & $<0.10$ \\
\hline $2 / 3 / 2009$ & 1020 & -- & -- & -- & -- & $<0.10$ \\
\hline 2/3/2009 & 1021 & $<100$ & 40 & $<1.00$ & -- & -- \\
\hline $3 / 25 / 2009$ & 1035 & -- & -- & -- & -- & $<0.10$ \\
\hline $3 / 25 / 2009$ & 1036 & $<100$ & 30 & 1.00 & -- & -- \\
\hline 4/4/2009 & 1310 & -- & -- & -- & -- & 0.59 \\
\hline $4 / 4 / 2009$ & 1311 & $<100$ & 17 & $<1.00$ & -- & -- \\
\hline $4 / 4 / 2009$ & 1315 & -- & -- & -- & 0.730 & 0.34 \\
\hline $4 / 4 / 2009$ & 1316 & $<100$ & 17 & $<1.00$ & -- & -- \\
\hline 4/7/2009 & 1155 & -- & -- & -- & 0.530 & 0.45 \\
\hline $4 / 7 / 2009$ & 1156 & $<100$ & 21 & 1.00 & -- & -- \\
\hline 4/7/2009 & 1200 & -- & -- & -- & -- & -- \\
\hline $4 / 15 / 2009$ & 1040 & -- & -- & -- & -- & 0.82 \\
\hline $4 / 15 / 2009$ & 1041 & $<100$ & 8 & 1.00 & -- & -- \\
\hline 4/18/2009 & 1010 & -- & -- & -- & -- & 0.53 \\
\hline 4/18/2009 & 1011 & $<100$ & $<5$ & 1.00 & -- & -- \\
\hline $5 / 4 / 2009$ & 1225 & -- & -- & -- & 1.650 & 1.90 \\
\hline $5 / 4 / 2009$ & 1226 & $<100$ & $<5$ & $<1.00$ & -- & -- \\
\hline $5 / 19 / 2009$ & 1145 & -- & -- & -- & -- & $<0.10$ \\
\hline $5 / 19 / 2009$ & 1146 & $<100$ & $<5$ & 2.00 & -- & -- \\
\hline $8 / 17 / 2009$ & 1050 & -- & -- & -- & -- & $<0.10$ \\
\hline $8 / 17 / 2009$ & 1051 & $<100$ & 25 & $<1.00$ & -- & -- \\
\hline $11 / 16 / 2009$ & 1015 & -- & -- & -- & -- & $<0.10$ \\
\hline
\end{tabular}


Table 9. Summary of trace element and atrazine concentrations from water samples collected as part of the Equus Beds Experimental Passive Recharge Project at RB1, 2009-2010._Continued

$\left[\mu \mathrm{g} / \mathrm{L}\right.$, micrograms per liter; --, not determined or not applicable; $\mathrm{M}^{*}$, presence of material verified, but not quantified; $\mathrm{E}^{* *}$, estimated: $<$, less than; $>$, greater than]

\begin{tabular}{|c|c|c|c|c|c|c|}
\hline $\begin{array}{c}\text { Date of sample } \\
\text { collection } \\
\text { (month/day/year) }\end{array}$ & $\begin{array}{l}\text { Sample } \\
\text { start } \\
\text { time }\end{array}$ & $\begin{array}{l}\text { Iron } \\
(\mu \mathrm{g} / \mathrm{L})\end{array}$ & $\begin{array}{c}\text { Manganese } \\
(\mu \mathrm{g} / \mathrm{L})\end{array}$ & $\begin{array}{c}\text { Arsenic } \\
(\mu \mathrm{g} / \mathrm{L})\end{array}$ & $\begin{array}{c}\text { Atrazine, } \\
\text { recoverable } \\
\text { ( } \mu \mathrm{g} / \mathrm{L})\end{array}$ & $\begin{array}{l}\text { Triazine screen, } \\
\text { enzyme link } \\
\text { immuno sorbent } \\
\text { assay, recoverable } \\
(\mu \mathrm{g} / \mathrm{L})\end{array}$ \\
\hline \multicolumn{7}{|c|}{ RB1-P shallow-Continued } \\
\hline $11 / 16 / 2009$ & 1016 & $<100$ & 46 & $<1.00$ & -- & -- \\
\hline $11 / 16 / 2009$ & 1017 & -- & -- & -- & -- & 0.11 \\
\hline $3 / 3 / 2010$ & 1020 & -- & -- & -- & -- & $<0.10$ \\
\hline $3 / 3 / 2010$ & 1021 & $<100$ & 63 & 1.40 & -- & -- \\
\hline \multicolumn{7}{|c|}{ RB1-P deep } \\
\hline $2 / 3 / 2009$ & 1150 & -- & -- & -- & -- & $<0.10$ \\
\hline $2 / 3 / 2009$ & 1151 & $<100$ & 41 & $<1.00$ & -- & -- \\
\hline $3 / 25 / 2009$ & 1205 & -- & -- & -- & -- & $<0.10$ \\
\hline $3 / 25 / 2009$ & 1206 & $<100$ & 31 & 1.00 & -- & -- \\
\hline $4 / 4 / 2009$ & 1440 & -- & -- & -- & -- & 0.60 \\
\hline $4 / 4 / 2009$ & 1441 & $<100$ & 17 & $<1.00$ & -- & -- \\
\hline 4/7/2009 & 1320 & -- & -- & -- & 0.470 & 0.71 \\
\hline 4/7/2009 & 1321 & $<100$ & 20 & 1.00 & -- & -- \\
\hline 4/7/2009 & 1325 & -- & -- & -- & -- & -- \\
\hline $4 / 15 / 2009$ & 1210 & -- & -- & -- & -- & 0.75 \\
\hline $4 / 15 / 2009$ & 1211 & $<100$ & 8 & $<1.00$ & -- & -- \\
\hline $4 / 18 / 2009$ & 1130 & -- & -- & -- & -- & 0.36 \\
\hline $4 / 18 / 2009$ & 1131 & $<100$ & $<5$ & $<1.00$ & -- & -- \\
\hline $4 / 18 / 2009$ & 1132 & -- & -- & -- & -- & 0.46 \\
\hline $5 / 4 / 2009$ & 1335 & -- & -- & -- & 1.710 & 1.10 \\
\hline $5 / 4 / 2009$ & 1336 & $<100$ & $<5$ & $<1.00$ & -- & -- \\
\hline $5 / 19 / 2009$ & 1300 & -- & -- & -- & -- & $<0.10$ \\
\hline $5 / 19 / 2009$ & 1301 & $<100$ & $<5$ & 1.00 & -- & -- \\
\hline $5 / 19 / 2009$ & 1302 & -- & -- & -- & -- & $<0.10$ \\
\hline $7 / 9 / 2009$ & 1055 & -- & -- & -- & 0.100 & 0.34 \\
\hline $7 / 9 / 2009$ & 1056 & $<100$ & 49 & $<1.00$ & -- & -- \\
\hline $7 / 13 / 2009$ & 1235 & -- & -- & -- & -- & $<0.10$ \\
\hline $7 / 13 / 2009$ & 1236 & $<100$ & 121 & 3.00 & -- & -- \\
\hline $7 / 20 / 2009$ & 1000 & -- & -- & -- & $<0.050$ & 0.11 \\
\hline $7 / 20 / 2009$ & 1001 & $<100$ & 199 & 4.00 & -- & -- \\
\hline $8 / 12 / 2009$ & 1020 & -- & -- & -- & -- & $<0.10$ \\
\hline $8 / 12 / 2009$ & 1021 & 130 & 219 & 4.00 & -- & -- \\
\hline $8 / 17 / 2009$ & 1210 & -- & -- & -- & -- & $<0.10$ \\
\hline $8 / 17 / 2009$ & 1211 & $<100$ & 30 & $<1.00$ & -- & -- \\
\hline $11 / 16 / 2009$ & 1125 & -- & -- & -- & -- & \\
\hline $3 / 3 / 2010$ & 1135 & -- & -- & -- & -- & $<0.10$ \\
\hline $3 / 3 / 2010$ & 1136 & $<100$ & 56 & 1.40 & -- & -- \\
\hline \multicolumn{7}{|c|}{ RB1-P TR } \\
\hline $3 / 26 / 2009$ & 1020 & -- & -- & -- & -- & $<0.10$ \\
\hline $3 / 26 / 2009$ & 1021 & $<100$ & 28 & $<1.00$ & -- & -- \\
\hline 4/3/2009 & 1350 & -- & -- & -- & -- & 0.37 \\
\hline $4 / 3 / 2009$ & 1351 & $<100$ & 10 & $<1.00$ & -- & -- \\
\hline $4 / 3 / 2009$ & 1352 & -- & -- & -- & -- & 0.44 \\
\hline 4/7/2009 & 1000 & -- & -- & -- & 0.490 & 0.54 \\
\hline 4/7/2009 & 1001 & $<100$ & 21 & 1.00 & -- & -- \\
\hline $4 / 7 / 2009$ & 1002 & -- & -- & -- & 0.440 & -- \\
\hline 4/7/2009 & 1005 & -- & -- & -- & -- & 0.44 \\
\hline 4/7/2009 & 1006 & $<100$ & 21 & 1.00 & -- & -- \\
\hline $4 / 14 / 2009$ & 1131 & $<100$ & 9 & $<1.00$ & -- & -- \\
\hline $4 / 14 / 2009$ & 1330 & -- & -- & -- & -- & 0.71 \\
\hline
\end{tabular}


Table 9. Summary of trace element and atrazine concentrations from water samples collected as part of the Equus Beds Experimental Passive Recharge Project at RB1, 2009-2010.-Continued

$\left[\mu \mathrm{g} / \mathrm{L}\right.$, micrograms per liter; --, not determined or not applicable; $\mathrm{M}^{*}$, presence of material verified, but not quantified; $\mathrm{E}^{* *}$, estimated: $<$, less than; >, greater than]

\begin{tabular}{|c|c|c|c|c|c|c|}
\hline $\begin{array}{c}\text { Date of sample } \\
\text { collection } \\
\text { (month/day/year) }\end{array}$ & $\begin{array}{c}\text { Sample } \\
\text { start } \\
\text { time }\end{array}$ & $\begin{array}{c}\text { Iron } \\
(\mu \mathrm{g} / \mathrm{L})\end{array}$ & $\begin{array}{c}\text { Manganese } \\
(\mu \mathrm{g} / \mathrm{L})\end{array}$ & $\begin{array}{c}\text { Arsenic } \\
\text { ( } \mu \mathrm{g} / \mathrm{L})\end{array}$ & $\begin{array}{c}\text { Atrazine, } \\
\text { recoverable } \\
\text { ( } \mu \mathrm{g} / \mathrm{L})\end{array}$ & $\begin{array}{l}\text { Triazine screen, } \\
\text { enzyme link } \\
\text { immuno sorbent } \\
\text { assay, recoverable } \\
(\mu \mathrm{g} / \mathrm{L})\end{array}$ \\
\hline \multicolumn{7}{|c|}{ RB1-P TR-Continued } \\
\hline $4 / 17 / 2009$ & 1250 & -- & -- & -- & -- & 0.61 \\
\hline $4 / 17 / 2009$ & 1251 & $<100$ & 5 & 1.00 & -- & -- \\
\hline $4 / 23 / 2009$ & 1121 & $<100$ & $<5$ & 2.00 & -- & -- \\
\hline $4 / 23 / 2009$ & 1220 & -- & -- & -- & -- & 0.48 \\
\hline $4 / 23 / 2009$ & 1222 & -- & -- & -- & -- & 0.44 \\
\hline $4 / 27 / 2009$ & 1140 & -- & -- & -- & -- & 0.69 \\
\hline $4 / 27 / 2009$ & 1141 & $<100$ & $<5$ & 2.00 & -- & -- \\
\hline $5 / 4 / 2009$ & 1055 & -- & -- & -- & 1.760 & 1.40 \\
\hline $5 / 4 / 2009$ & 1056 & $<100$ & $<5$ & $<1.00$ & -- & -- \\
\hline $5 / 4 / 2009$ & 1057 & -- & -- & -- & -- & 1.80 \\
\hline $5 / 19 / 2009$ & 1020 & -- & -- & -- & -- & $<0.10$ \\
\hline $5 / 19 / 2009$ & 1021 & $<100$ & $<5$ & 1.00 & -- & -- \\
\hline \multicolumn{7}{|c|}{ Diverted SW, PAC building } \\
\hline $4 / 3 / 2009$ & 1010 & -- & -- & -- & -- & 3.02 \\
\hline $4 / 3 / 2009$ & 1011 & $<100$ & 33 & 2.30 & -- & -- \\
\hline $4 / 14 / 2009$ & 1010 & -- & -- & -- & 3.370 & 2.85 \\
\hline $4 / 14 / 2009$ & 1011 & $<100$ & 24 & 2.00 & -- & -- \\
\hline $4 / 14 / 2009$ & 1012 & -- & -- & -- & 3.130 & -- \\
\hline $4 / 17 / 2009$ & 0950 & -- & -- & -- & -- & 4.05 \\
\hline $4 / 17 / 2009$ & 0951 & $<100$ & 10 & 2.90 & -- & -- \\
\hline
\end{tabular}

" National Water Information System: Web Interface Help System, accessed March 17, 2011, at http://nwis.waterdata.usgs.gov/ nwis/help/help? codes help\#remark cd.

${ }^{* *}$ Values may be reported as estimated (E) if values are out of instrument calibration range, data quantification was not performed according to method specific criteria, or deviation for the standard operating procedure was required. Values are considered detections. (Childress and others, 1999). 
Table 10. Saturation indices calculated for groundwater samples collected from RB1 sites, January 2009-March 2010.

\begin{tabular}{|c|c|c|c|c|}
\hline \multirow{2}{*}{$\begin{array}{c}\text { Date of sample } \\
\text { (month/day/year) }\end{array}$} & \multicolumn{4}{|c|}{ Mineral (chemical formula) saturation indices } \\
\hline & $\begin{array}{l}\text { Calcite } \\
\left(\mathrm{CaCO}_{3}\right)\end{array}$ & $\begin{array}{c}\text { Iron hydroxide } \\
\mathrm{Fe}_{3}(\mathrm{OH})_{8}\end{array}$ & $\begin{array}{c}\text { Manganite } \\
\text { (MnOOH) }\end{array}$ & $\begin{array}{c}\text { Scorodite } \\
\left(\mathrm{FeAsO}_{4}: 2 \mathrm{H}_{2} \mathrm{O}\right)\end{array}$ \\
\hline \multicolumn{5}{|c|}{ IW-09 shallow } \\
\hline $2 / 10 / 2009$ & -1.02 & -2.31 & -1.46 & -6.59 \\
\hline $4 / 2 / 2009$ & -1.07 & -2.34 & -1.43 & -6.57 \\
\hline $4 / 22 / 2009$ & -0.83 & -1.96 & -1.18 & -6.74 \\
\hline $6 / 10 / 2009$ & -1.03 & -2.15 & -1.69 & -6.62 \\
\hline $7 / 14 / 2009$ & -0.63 & -1.38 & -0.93 & -6.93 \\
\hline $8 / 19 / 2009$ & -0.65 & -1.37 & -0.89 & -6.91 \\
\hline $11 / 17 / 2009$ & -0.63 & -1.33 & -0.84 & -6.91 \\
\hline $3 / 9 / 2010$ & -0.63 & -1.45 & -1.08 & -6.48 \\
\hline \multicolumn{5}{|c|}{ IW-09 deep } \\
\hline $2 / 10 / 2009$ & -0.28 & & -1.08 & -5.74 \\
\hline $4 / 2 / 2009$ & -0.37 & -1.14 & -1.24 & -5.67 \\
\hline $4 / 22 / 2009$ & -0.19 & -0.39 & -1.51 & -5.82 \\
\hline $6 / 10 / 2009$ & -0.28 & -0.58 & -1.73 & -5.75 \\
\hline $7 / 14 / 2009$ & -0.08 & -0.16 & -1.33 & -5.88 \\
\hline $8 / 19 / 2009$ & -0.08 & -0.31 & -1.34 & -5.98 \\
\hline $11 / 17 / 2009$ & 0.13 & -0.69 & -0.34 & -6.22 \\
\hline $3 / 9 / 2010$ & -0.23 & -0.03 & -1.18 & -5.85 \\
\hline \multicolumn{5}{|c|}{ RB1-MN deep } \\
\hline $2 / 9 / 2009$ & -0.34 & 1.62 & -1.31 & -4.76 \\
\hline $4 / 1 / 2009$ & -0.45 & 1.32 & -1.46 & -4.70 \\
\hline $4 / 21 / 2009$ & -0.17 & 2.42 & -1.57 & -4.96 \\
\hline $6 / 25 / 2009$ & -0.27 & 1.52 & -1.18 & -4.89 \\
\hline $7 / 14 / 2009$ & -0.42 & 1.94 & -2.17 & -4.68 \\
\hline $8 / 19 / 2009$ & -0.26 & 2.23 & -1.79 & -4.87 \\
\hline $11 / 18 / 2009$ & 0.06 & 2.13 & -0.53 & -5.18 \\
\hline $3 / 8 / 2010$ & -0.04 & 2.59 & -1.35 & -5.03 \\
\hline \multicolumn{5}{|c|}{ RB1-MN shallow } \\
\hline 2/9/2009 & -0.52 & 3.18 & -2.06 & -4.10 \\
\hline $4 / 1 / 2009$ & -0.63 & 2.97 & -2.21 & -4.04 \\
\hline $4 / 21 / 2009$ & -0.43 & 3.36 & -1.81 & -4.11 \\
\hline $6 / 25 / 2009$ & -0.51 & 2.96 & -2.07 & -4.15 \\
\hline $7 / 14 / 2009$ & -0.73 & 3.06 & -3.20 & -4.04 \\
\hline 8/19/2009 & -0.44 & 3.79 & -2.58 & -4.24 \\
\hline $11 / 18 / 2009$ & -0.21 & 3.72 & -1.46 & -4.28 \\
\hline $3 / 8 / 2010$ & -0.30 & 4.21 & -2.27 & -4.09 \\
\hline \multicolumn{5}{|c|}{ RB1-MS deep } \\
\hline $2 / 4 / 2009$ & -0.45 & -0.21 & -1.33 & -5.33 \\
\hline $3 / 24 / 2009$ & -0.32 & 0.01 & -1.13 & -5.35 \\
\hline $4 / 6 / 2009$ & -0.43 & -0.10 & -1.31 & -5.26 \\
\hline 4/9/2009 & -0.31 & 0.57 & -1.76 & -5.39 \\
\hline $4 / 16 / 2009$ & -0.13 & 0.83 & -1.37 & -5.59 \\
\hline 4/20/2009 & -0.31 & 0.57 & -1.75 & -5.37 \\
\hline $5 / 6 / 2009$ & -0.02 & 0.96 & -1.19 & -5.74 \\
\hline $5 / 20 / 2009$ & -0.32 & 0.54 & -1.77 & -5.40 \\
\hline $6 / 25 / 2009$ & 0.08 & 1.02 & -1.01 & -5.89 \\
\hline 7/8/2009 & -0.21 & 0.60 & -1.61 & -5.56 \\
\hline $7 / 13 / 2009$ & -0.22 & 0.54 & -1.62 & -5.53 \\
\hline $7 / 20 / 2009$ & -0.41 & 0.30 & -2.01 & -5.27 \\
\hline $8 / 18 / 2009$ & -0.35 & 0.38 & -1.81 & -5.45 \\
\hline $11 / 18 / 2009$ & -0.06 & 0.25 & -0.63 & -5.78 \\
\hline $3 / 1 / 2010$ & -0.03 & 0.92 & -1.11 & -5.80 \\
\hline
\end{tabular}


Table 10. Saturation indices calculated for groundwater samples collected from RB1 sites, January 2009-March 2010.-Continued

\begin{tabular}{|c|c|c|c|c|}
\hline \multirow[b]{2}{*}{$\begin{array}{c}\text { Date of sample } \\
\text { (month/day/year) }\end{array}$} & \multicolumn{4}{|c|}{ Mineral (chemical formula) saturation indices } \\
\hline & $\begin{array}{l}\text { Calcite } \\
\left(\mathrm{CaCO}_{3}\right)\end{array}$ & $\begin{array}{c}\text { Iron hydroxide } \\
\mathrm{Fe}_{3}(\mathrm{OH})_{8}\end{array}$ & $\begin{array}{c}\text { Manganite } \\
\text { (MnOOH) }\end{array}$ & $\begin{array}{c}\text { Scorodite } \\
\left(\mathrm{FeAsO}_{4}: 2 \mathrm{H}_{2} \mathrm{O}\right)\end{array}$ \\
\hline \multicolumn{5}{|c|}{ RB1-MS shallow } \\
\hline $2 / 4 / 2009$ & -0.90 & 1.24 & -2.64 & -4.76 \\
\hline $3 / 24 / 2009$ & -0.80 & 1.33 & -2.47 & -4.94 \\
\hline $4 / 6 / 2009$ & -0.82 & 1.47 & -2.46 & -4.82 \\
\hline $4 / 9 / 2009$ & -0.79 & 1.95 & -3.09 & -4.94 \\
\hline $4 / 16 / 2009$ & -0.52 & 2.50 & -2.50 & -5.08 \\
\hline $4 / 20 / 2009$ & -0.70 & 2.11 & -2.90 & -4.93 \\
\hline $5 / 6 / 2009$ & -0.41 & 2.32 & -2.03 & -5.18 \\
\hline $5 / 20 / 2009$ & -0.71 & 1.89 & -2.76 & -4.95 \\
\hline $6 / 25 / 2009$ & -0.31 & 2.54 & -2.01 & -5.41 \\
\hline $7 / 8 / 2009$ & -0.59 & 2.24 & -2.77 & -5.12 \\
\hline $7 / 13 / 2009$ & -0.58 & 2.02 & -2.64 & -5.04 \\
\hline $7 / 20 / 2009$ & -0.69 & 1.74 & -2.84 & -5.09 \\
\hline $8 / 18 / 2009$ & -0.68 & 1.90 & -2.81 & -5.04 \\
\hline $11 / 18 / 2009$ & -0.45 & 2.49 & -2.18 & -5.18 \\
\hline $3 / 1 / 2010$ & -0.45 & 2.72 & -2.27 & -5.12 \\
\hline \multicolumn{5}{|c|}{ RB1-P deep } \\
\hline $2 / 3 / 2009$ & -1.01 & -1.89 & -2.17 & -6.32 \\
\hline $3 / 25 / 2009$ & -0.94 & -1.95 & -2.37 & -6.49 \\
\hline 4/4/2009 & -1.16 & -1.43 & -2.74 & -6.56 \\
\hline 4/7/2009 & -0.53 & 0.05 & -1.26 & -6.98 \\
\hline $4 / 15 / 2009$ & -0.59 & -1.21 & -1.92 & -6.94 \\
\hline $4 / 18 / 2009$ & -0.58 & -1.56 & -2.36 & -7.07 \\
\hline $5 / 4 / 2009$ & -1.32 & -1.86 & -3.15 & -6.77 \\
\hline $5 / 19 / 2009$ & -0.78 & -2.36 & -3.17 & -6.73 \\
\hline 7/9/2009 & -0.20 & -1.02 & -1.49 & -7.16 \\
\hline $7 / 13 / 2009$ & -0.26 & -0.98 & -1.50 & -6.57 \\
\hline $7 / 20 / 2009$ & 0.25 & -0.38 & -0.37 & -7.13 \\
\hline $8 / 12 / 2009$ & -0.11 & -0.51 & -1.07 & -6.46 \\
\hline $8 / 17 / 2009$ & -0.68 & -1.45 & -2.67 & -6.76 \\
\hline $11 / 16 / 2009$ & -0.72 & -1.22 & -2.50 & -6.70 \\
\hline \multicolumn{5}{|c|}{ RB1-P shallow } \\
\hline $1 / 21 / 2009$ & -1.08 & -2.29 & -2.78 & -6.48 \\
\hline $2 / 3 / 2009$ & -1.05 & -1.66 & -2.07 & -6.25 \\
\hline $3 / 25 / 2009$ & -0.94 & -1.93 & -2.38 & -6.48 \\
\hline $4 / 4 / 2009$ & -1.17 & -1.36 & -2.74 & -6.54 \\
\hline 4/7/2009 & -0.53 & 0.20 & -1.18 & -6.93 \\
\hline $4 / 15 / 2009$ & -0.63 & -1.14 & -1.89 & -6.91 \\
\hline $4 / 18 / 2009$ & -0.52 & -1.53 & -2.36 & -7.06 \\
\hline $5 / 4 / 2009$ & -1.29 & -1.90 & -3.17 & -6.79 \\
\hline $5 / 19 / 2009$ & -0.78 & -2.39 & -3.20 & -6.44 \\
\hline $8 / 17 / 2009$ & -0.69 & -1.50 & -2.72 & -6.76 \\
\hline $11 / 16 / 2009$ & -0.75 & -1.31 & -2.41 & -6.71 \\
\hline \multicolumn{5}{|c|}{ RB1-P TR } \\
\hline $3 / 26 / 2009$ & -0.85 & -1.67 & -2.16 & -6.52 \\
\hline 4/3/2009 & -0.80 & -0.23 & -1.88 & -6.73 \\
\hline 4/7/2009 & -0.55 & 0.27 & -1.14 & -6.91 \\
\hline $4 / 17 / 2009$ & -0.63 & -1.75 & -2.57 & -6.98 \\
\hline $4 / 23 / 2009$ & -0.74 & -1.41 & -2.29 & -6.91 \\
\hline $4 / 27 / 2009$ & -0.98 & -1.63 & -2.39 & -6.77 \\
\hline $5 / 4 / 2009$ & -1.21 & -1.64 & -2.93 & -6.84 \\
\hline $5 / 19 / 2009$ & -0.81 & -2.05 & -2.95 & -6.77 \\
\hline
\end{tabular}


Table 10. Saturation indices calculated for groundwater samples collected from RB1 sites, January 2009-March 2010.-Continued

\begin{tabular}{|c|c|c|c|c|}
\hline \multirow{2}{*}{$\begin{array}{c}\text { Date of sample } \\
\text { (month/day/year) }\end{array}$} & \multicolumn{4}{|c|}{ Mineral (chemical formula) saturation indices } \\
\hline & $\begin{array}{l}\text { Calcite } \\
\left(\mathrm{CaCO}_{3}\right)\end{array}$ & $\begin{array}{c}\text { Iron hydroxide } \\
\mathrm{Fe}_{3}(\mathrm{OH})_{8}\end{array}$ & $\begin{array}{c}\text { Manganite } \\
\text { (MnOOH) }\end{array}$ & $\begin{array}{c}\text { Scorodite } \\
\left(\mathrm{FeAsO}_{4}: 2 \mathrm{H}_{2} \mathrm{O}\right)\end{array}$ \\
\hline \multicolumn{5}{|c|}{ RB1-PMS deep } \\
\hline $1 / 22 / 2009$ & -0.58 & 1.61 & -1.76 & -5.09 \\
\hline $2 / 2 / 2009$ & -0.91 & -2.28 & -2.28 & -6.58 \\
\hline $3 / 26 / 2009$ & -0.88 & -1.88 & -2.22 & -6.59 \\
\hline $4 / 4 / 2009$ & -0.90 & -1.60 & -2.43 & -6.60 \\
\hline $4 / 8 / 2009$ & -0.95 & -1.58 & -2.14 & -6.57 \\
\hline $4 / 15 / 2009$ & -0.76 & -1.46 & -1.55 & -6.72 \\
\hline $4 / 18 / 2009$ & -0.66 & -1.36 & -1.43 & -6.83 \\
\hline $5 / 6 / 2009$ & -1.19 & -2.27 & -2.42 & -6.57 \\
\hline $5 / 20 / 2009$ & -0.95 & -2.13 & -2.29 & -6.65 \\
\hline $7 / 8 / 2009$ & -0.44 & -1.63 & -2.86 & -6.85 \\
\hline $7 / 13 / 2009$ & -0.46 & -1.87 & -2.55 & -6.78 \\
\hline $7 / 20 / 2009$ & -0.29 & -1.68 & -1.81 & -6.87 \\
\hline $8 / 18 / 2009$ & -0.77 & -2.09 & -2.64 & -6.69 \\
\hline $11 / 17 / 2009$ & -0.76 & -1.50 & -2.49 & -6.72 \\
\hline $3 / 2 / 2010$ & -0.63 & -1.26 & -2.29 & -6.57 \\
\hline \multicolumn{5}{|c|}{ RB1-PMS shallow } \\
\hline $4 / 8 / 2009$ & & -1.66 & -2.64 & -6.58 \\
\hline $4 / 15 / 2009$ & -0.90 & -1.72 & -2.26 & -6.66 \\
\hline $4 / 18 / 2009$ & -0.68 & -1.41 & -1.92 & -6.86 \\
\hline $5 / 6 / 2009$ & -1.18 & -2.28 & -2.74 & -6.58 \\
\hline $5 / 20 / 2009$ & -0.80 & -1.92 & -2.49 & -6.74 \\
\hline $7 / 8 / 2009$ & -0.63 & -1.62 & -2.45 & -6.87 \\
\hline $7 / 13 / 2009$ & -0.50 & -1.48 & -2.54 & -6.85 \\
\hline $7 / 20 / 2009$ & -0.45 & -1.64 & -2.35 & -6.86 \\
\hline $8 / 18 / 2009$ & -0.69 & -1.67 & -2.45 & -6.84 \\
\hline $11 / 17 / 2009$ & -0.66 & -1.29 & -2.56 & -6.80 \\
\hline $3 / 2 / 2010$ & -0.62 & -1.28 & -2.61 & -6.57 \\
\hline \multicolumn{5}{|c|}{ RB1 source water } \\
\hline $4 / 3 / 2009$ & -2.46 & -3.33 & -3.81 & -6.16 \\
\hline $4 / 14 / 2009$ & -0.29 & 0.25 & -1.49 & -7.47 \\
\hline $4 / 17 / 2009$ & -0.79 & -1.46 & -3.10 & -6.72 \\
\hline
\end{tabular}

Publishing support provided by:

Rolla Publishing Service Center

For additional information concerning this publication, contact:

Director, USGS Kansas Water Science Center

4821 Quail Crest Place, Lawrence, KS (785) 842-9909

Or visit the Kansas Water Science Center Web Site at:

http://ks.water.usgs.gov 

